Prepared in cooperation with the Oklahoma Water Resources Board

\title{
Hydrogeology and Simulation of Groundwater Flow in the Arbuckle-Simpson Aquifer, South-Central Oklahoma
}

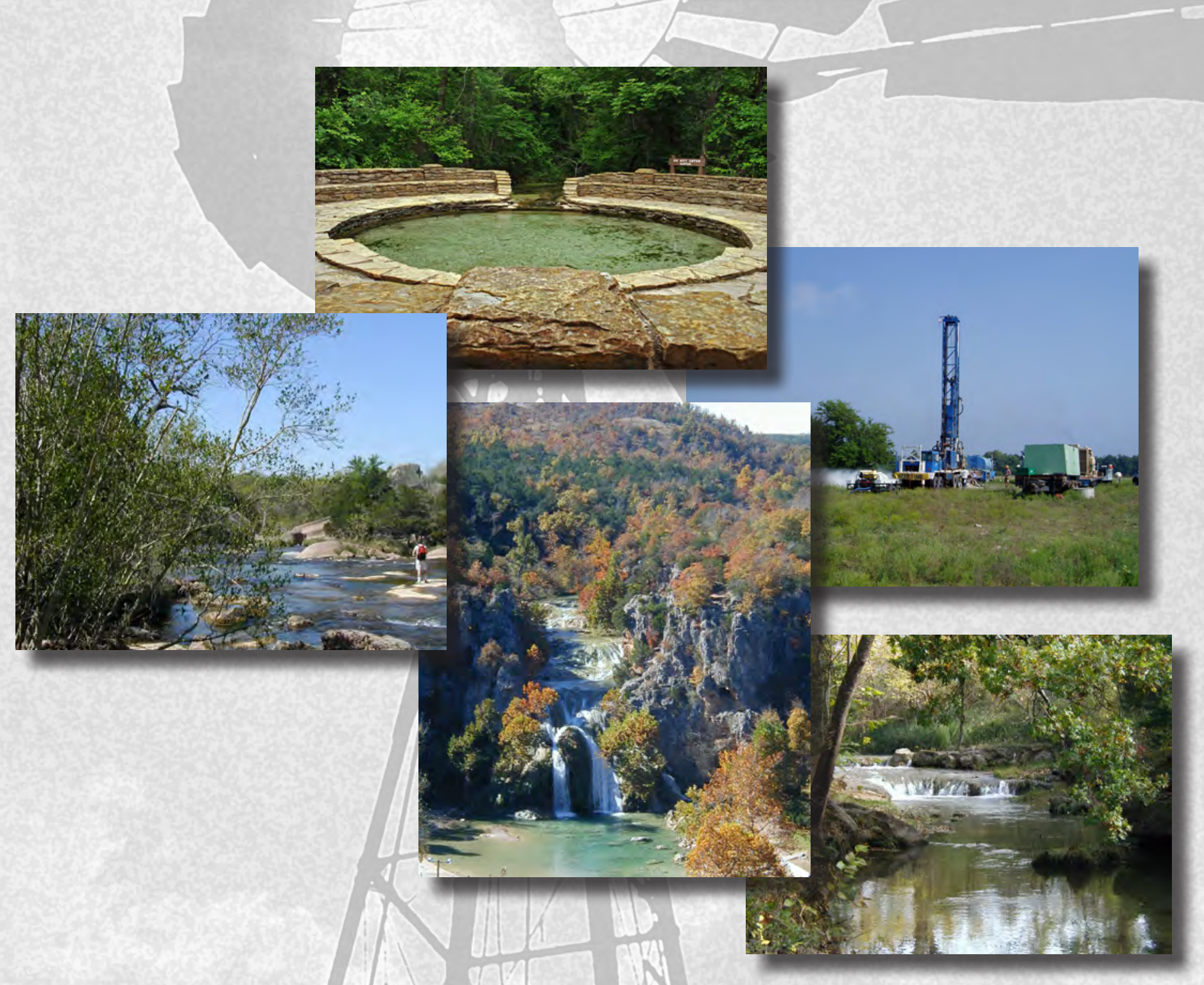

Scientific Investigations Report 2011-5029

U.S. Department of the Interior

U.S. Geological Survey 
Cover. Clockwise from upper left: Buffalo Springs, Chickasaw National Recreation Area, Oklahoma. Drilling a test well in the ArbuckleSimpson aquifer near Connerville, Oklahoma. Pennington Creek at Devil's Den Natural Area near Tishomingo, Oklahoma. Turner Falls near Davis, Oklahoma. Travertine Creek, Chickasaw National Recreation Area, Oklahoma. Photograph of Buffalo Springs by Chris Neel, Oklahoma Water Resources Board; all others by Noel Osborn, Oklahoma Water Resources Board. 


\section{Hydrogeology and Simulation of Groundwater Flow in the Arbuckle-Simpson Aquifer, South-Central Oklahoma}

By Scott Christenson, Noel I. Osborn, Christopher R. Neel, Jason R. Faith, Charles D. Blome, James Puckette, and Michael P. Pantea

Prepared in cooperation with the Oklahoma Water Resources Board

Scientific Investigations Report 2011-5029 


\title{
U.S. Department of the Interior \\ KEN SALAZAR, Secretary \\ U.S. Geological Survey \\ Marcia K. McNutt, Director
}

\section{U.S. Geological Survey, Reston, Virginia: 2011}

\author{
This and other USGS information products are available at http://store.usgs.gov/ \\ U.S. Geological Survey \\ Box 25286, Denver Federal Center \\ Denver, CO 80225 \\ To learn about the USGS and its information products visit http://www.usgs.gov/ \\ 1-888-ASK-USGS
}

Any use of trade, product, or firm names is for descriptive purposes only and does not imply endorsement by the U.S. Government.

Although this report is in the public domain, permission must be secured from the individual copyright owners to reproduce any copyrighted materials contained within this report.

Suggested citation:

Christenson, Scott, Osborn, N.I., Neel, C.R., Faith, J.R., Blome, C.D., Puckette, James, and Pantea, M.P., 2011, Hydrogeology and simulation of groundwater flow in the Arbuckle-Simpson aquifer, south-central Oklahoma: U.S. Geological Survey Scientific Investigations Report 2011-5029, 104 p. 


\section{Acknowledgments}

The Arbuckle-Simpson Hydrology Study was funded primarily by Federal funds through a Bureau of Reclamation appropriation, and matching funds from the State of Oklahoma. The Bureau ensured Federal regulatory compliance, provided assistance with technical issues and public involvement, and offered support throughout the study.

The authors are indebted to the many land owners, municipalities, and operators of rural water districts who provided access to their wells and springs during this study. This report would not have been possible without their assistance and their permission to work on their land and facilities.

The Arbuckle-Simpson Hydrology Study was conceived and directed by the Oklahoma Legislature and the staff and board members of the Oklahoma Water Resources Board. Many members of the Legislature, Board, and staff contributed to this study.

From the beginning, the Arbuckle-Simpson Hydrology Study was intended to be a collaborative effort between researchers and administrators in several agencies, including the Oklahoma Water Resources Board, the U.S. Geological Survey, the U.S. Environmental Protection Agency, and the Oklahoma Geological Survey; and universities, including Oklahoma State University and the University of Oklahoma. The authors wish to express their gratitude and appreciation for the exchange of data and ideas with Dr. Todd Halihan (Oklahoma State University), Dr. Allegra Hosford Scheirer (Stanford University), Dr. Randall Ross (U.S. Environmental Protection Agency), Dr. Neil Suneson (Oklahoma Geological Survey), and Dr. Daniel Scheirer (U.S. Geological Survey). Dr. Baxter Vieux (University of Oklahoma) provided hydroclimatic data that proved to be essential to the success of the study. Jennifer Back from the National Park Service provided groundwater-level data. Exporting data from the EarthVision ${ }^{\mathrm{TM}}$ software used for the geologic framework model required considerable processing. The authors thank Skip Pack with Dynamic Graphics, Inc., for his expertise and time to do the discretization conversions. 


\section{Contents}

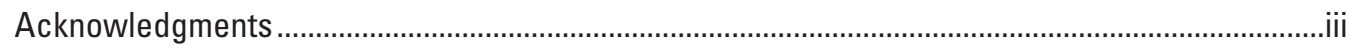

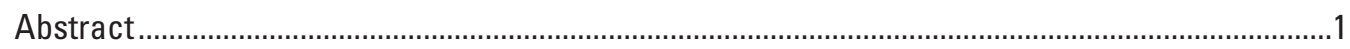

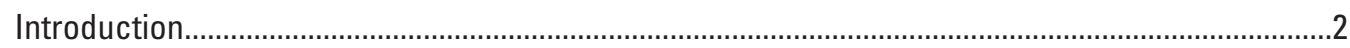

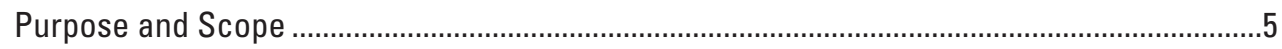

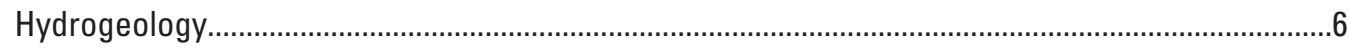

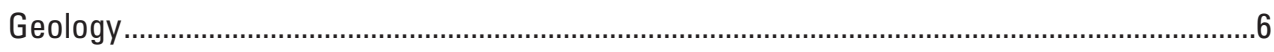

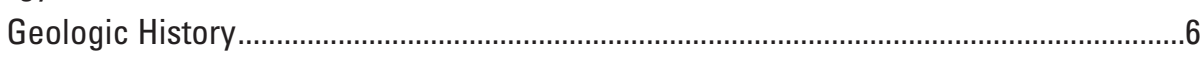

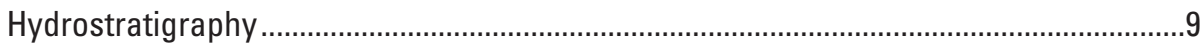

Basement Hydrostratigraphic Unit .......................................................................

Arbuckle-Timbered Hills Hydrostratigraphic Unit ...................................................12

Simpson Hydrostratigraphic Unit................................................................................. 13

Post-Simpson Hydrostratigraphic Unit .................................................................. 14

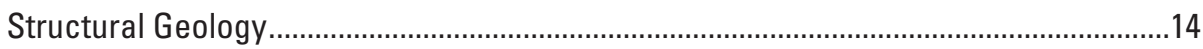

Three-Dimensional Geologic Framework Modeling .................................................................19

Geologic Data and Interpretation Methods ...................................................................19

Model Construction ............................................................................................................19

Data Exported from the Geologic Framework Model .....................................................21

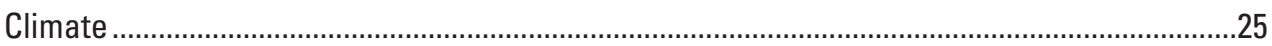

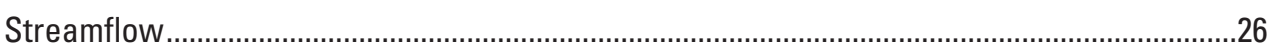

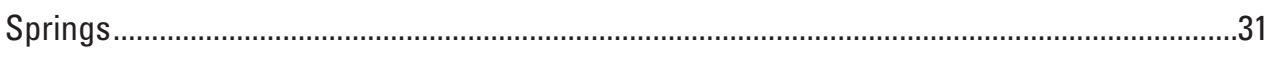

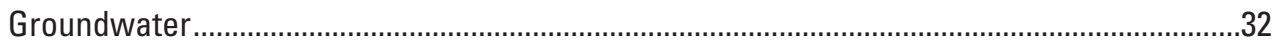

Extent of Fresh Groundwater ....................................................................................32

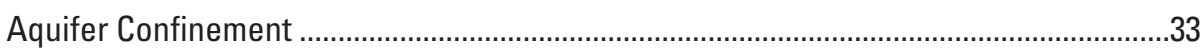

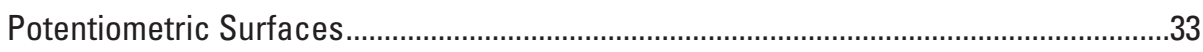

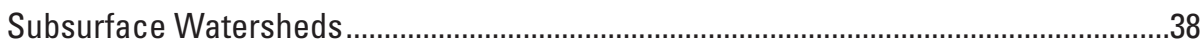

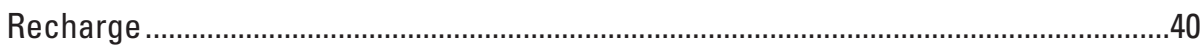

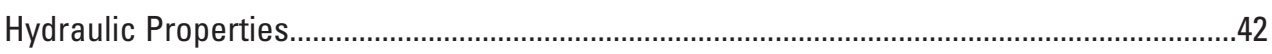

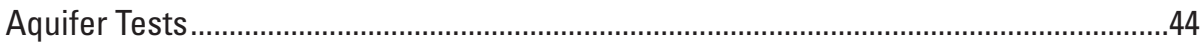

Regional Methods To Determine Storage Coefficient ........................................................46

Other Determinations of Hydraulic Properties ..................................................................48

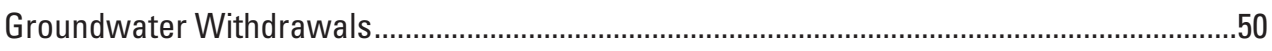

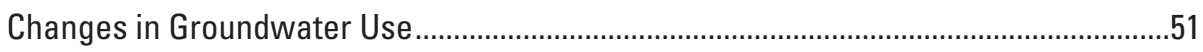

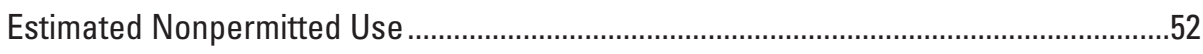

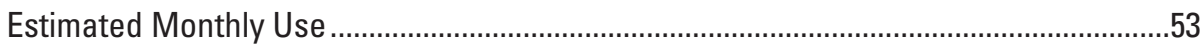

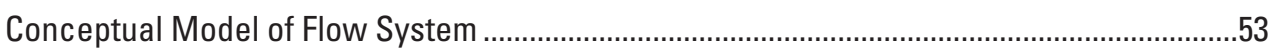

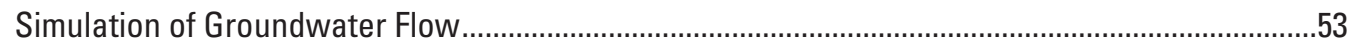

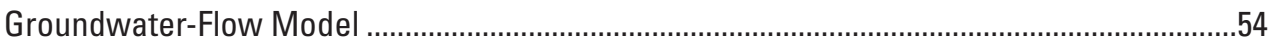

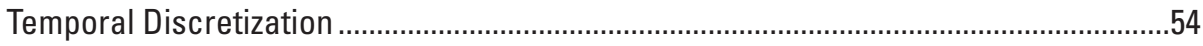

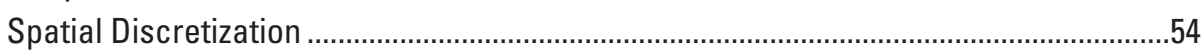

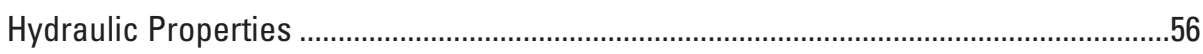

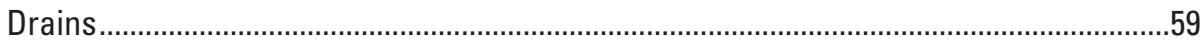

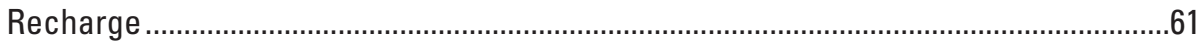




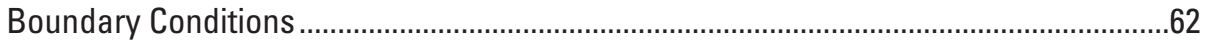

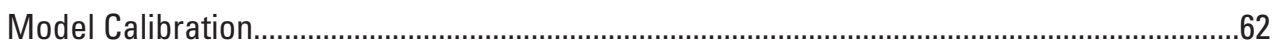

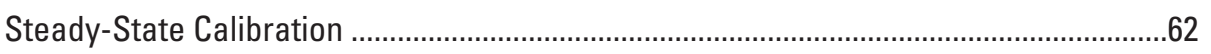

Transient Model Calibration ..........................................................................................

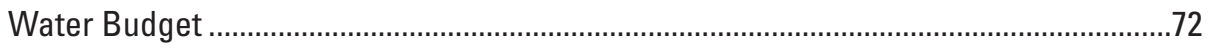

Simulations of Pathlines and Groundwater Traveltimes ................................................77

Model Simplifications, Assumptions, and Limitations ..................................................79

Simulations of Groundwater Withdrawals Distributed as an Equal

Proportionate Share

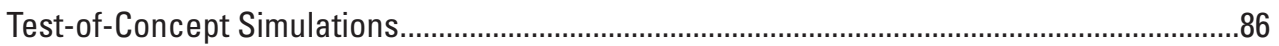

Effects of Distributed Withdrawals on Streams Other Than

Blue River and Pennington Creek .....................................................................................86

Effects of Distributed Withdrawals on Daily Streamflow .............................................8

Effects of Distributed Withdrawals on Locations of

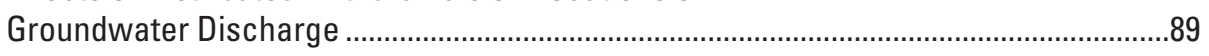

Simulation of Concentrated Groundwater Withdrawals from

the Eastern Arbuckle-Simpson Aquifer ..................................................................9

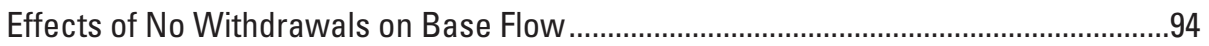

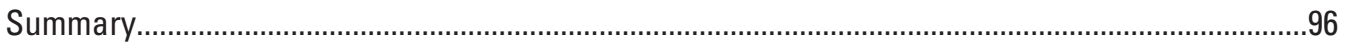

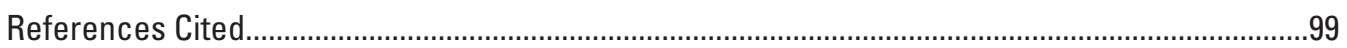

\section{Figures}

1-4 Maps showing-

1. The Arbuckle-Simpson aquifer outcrop, south-central Oklahoma .....................................3

2. Geographic features of the Arbuckle-Simpson aquifer study area, south-central Oklahoma...

3. Geologic map of the Arbuckle-Simpson aquifer study area, south-central Oklahoma...

4. Primary structural features of the Arbuckle-Simpson aquifer, south-central Oklahoma..

5. Graph showing type log of the Arbuckle Group in the eastern Arbuckle-Simpson aquifer, south-central Oklahoma.

6. Map showing altitude of the top of the Arbuckle Group and interpreted fault locations in the eastern Arbuckle-Simpson aquifer, south-central Oklahoma..

7. Generalized cross sections across the eastern Arbuckle-Simpson aquifer, south-central Oklahoma.

8. Seismic reflection line across the Hunton anticline showing interpreted basement horizon and faults

9-12 Maps showing-

9. Structure contour map of the basement surface and faults modeled by the geologic framework model of the eastern Arbuckle-Simpson aquifer, south-central Oklahoma.

10. Thickness of the Arbuckle-Timbered Hills hydrostratigraphic unit and faults modeled by the geologic framework model of the eastern Arbuckle-Simpson aquifer, south-central Oklahoma 
11. Thickness of the Simpson hydrostratigraphic unit and faults modeled by the geologic framework model of the eastern

Arbuckle-Simpson aquifer, south-central Oklahoma.

12. Thickness of the post-Simpson hydrostratigraphic unit and faults modeled by the geologic framework model of the eastern

Arbuckle-Simpson aquifer, south-central Oklahoma... . .24

13. Graph showing annual precipitation at Ada, Oklahoma, 1907-2008 ..............................25

14-16 Maps showing-

14. Streamgages located in the study area, south-central Oklahoma

15. Streamgages, synoptic discharge measurement sites, and streamflow discharge for February 19-22, 2007, for streams on or near the Arbuckle-Simpson aquifer, south-cental Oklahoma

16. Springs listed in the U.S. Geological Survey National Water Information System database in the Arbuckle-Simpson aquifer study area, south-central Oklahoma.

17. Graph showing precipitation and groundwater level at the Fittstown Mesonet station, south-central Oklahoma.

18-22 Maps showing-

18. Potentiometric surface in the eastern Arbuckle-Simpson aquifer, south-central Oklahoma, August 1995.

19. Potentiometric surface in the eastern Arbuckle-Simpson aquifer, south-central Oklahoma, June 2006.

20. Potentiometric surface in the eastern Arbuckle-Simpson aquifer, south-central Oklahoma, September 2006

21. Subsurface watersheds in the eastern Arbuckle-Simpson aquifer, south-central Oklahoma, based on synoptic water-level measurements

22. Surface watersheds in the eastern Arbuckle-Simpson aquifer, south-central Oklahoma.

23-24 Graphs showing -

23. Water level in the observation well in Murray County, Oklahoma, during the June 8-9, 2006, aquifer test

24. Modeled best fit of change in head during the recovery period in the observation well during a two-well aquifer test in Murray County, Oklahoma, June 8-9, 2006

25. Map showing wells equipped with instruments to measure water levels continuously in the eastern Arbuckle-Simpson aquifer, south-central Oklahoma

26. Graph showing reported groundwater use from the eastern Arbuckle-Simpson aquifer, 1964-2008, south-central Oklahoma.

27-28 Maps showing-

27. Average annual groundwater use from the eastern Arbuckle-Simpson aquifer, south-central Oklahoma, 2003-8.

28. Eastern Arbuckle-Simpson aquifer, south-central Oklahoma, MODFLOW model active nodes in layer 1 .

29. Cross sections through the eastern Arbuckle-Simpson aquifer, south-central Oklahoma, showing MODFLOW model discretization

30-33 Maps showing-

30. Drain cells in the eastern Arbuckle-Simpson aquifer, south-central Oklahoma, MODFLOW model. 
31. Eastern Arbuckle-Simpson aquifer, south-central Oklahoma,

MODFLOW model recharge zones.

32. Simulated steady-state potentiometric surface in layer 1

of the eastern Arbuckle-Simpson aquifer, south-central Oklahoma, that corresponds to the August 1995 synoptic measurement.

33. Comparison between observed and simulated heads in the eastern Arbuckle-Simpson aquifer, south-central Oklahoma, steady-state MODFLOW model

34-40 Graphs showing-

34. Comparison of weighted observed to weighted simulated head observations from the steady-state MODFLOW model corresponding to the August 1995 synoptic measurements

35. Weighted residual and weighted simulated head observations for the eastern Arbuckle-Simpson aquifer, south-central Oklahoma, MODFLOW model

36. Monthly gaged streamflow compared to monthly simulated streamflow for Blue River near Connerville, Oklahoma, for water years 2004-8.

37. Monthly gaged streamflow compared to monthly simulated streamflow for Pennington Creek near Reagan, Oklahoma, for water years 2004-8.

38. Comparison of observed and simulated heads for wells equipped with instruments to measure water levels continuously in the eastern Arbuckle-Simpson aquifer, south-central Oklahoma, for water years 2004-8.

39. Monthly recharge by zone for the eastern Arbuckle-Simpson aquifer, south-central Oklahoma, MODFLOW model water budget..

40. Monthly base flow to streams for the eastern Arbuckle-Simpson aquifer, south-central Oklahoma, MODFLOW model water budget...

41. Map showing pathlines computed by MODPATH based on the calibrated steady-state MODFLOW model of the eastern Arbuckle-Simpson aquifer, south-central Oklahoma.

42-45 Graphs showing-

42. Depletion of 5-year (water years 2004-8) average flow of Blue River near Connerville, Oklahoma, and Pennington Creek near Reagan, Okla., based on MODFLOW-simulated groundwater withdrawals distributed as an equal proportionate share

43. Depletion of the 75-percent exceedance of streamflow of Blue River near Connerville, Oklahoma, and Pennington Creek near Reagan, Okla., for water years 2004-8 based on MODFLOW-simulated withdrawals distributed as an equal proportionate share

44. Simulated streamflow for Blue River near Connerville, Oklahoma, for water years 2004-8 based on groundwater withdrawals distributed as an equal proportionate share

45. Simulated streamflow for Pennington Creek near Reagan, Oklahoma, for water years 2004-8 based on groundwater withdrawals distributed as an equal proportionate share 
46-47 Maps showing-

46. Drain cells in the eastern Arbuckle-Simpson aquifer, south-central Oklahoma, MODFLOW model discharging more than 1.0 cubic meter per day on August 10, 2005, for simulations of different equal proportionate shares

47. Location of the single MODFLOW well used to test the effects of concentrated withdrawals on the eastern Arbuckle-Simpson aquifer, south-central Oklahoma.

\section{Tables}

1. Generalized geologic history of the Arbuckle Mountains ..................................................

2. Comparison of time-stratigraphic, rock-stratigraphic, hydrostratigraphic, and hydrogeologic units in the Arbuckle-Simpson aquifer, south-central Oklahoma

3. Average monthly and average annual precipitation

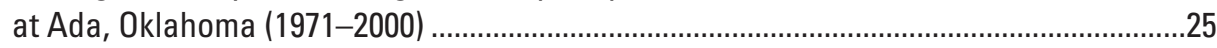

4. Temperature data for Ada, Oklahoma (1971-2000) .............................................................26

5. Monthly and annual precipitation at Ada, Oklahoma, for water years 2004-8

6. Annual evapotranspiration calculated for Blue River near Connerville, Oklahoma, and Pennington Creek near Reagan, Okla., for water years 2004-8

7. Descriptive statistics for selected streamgages located on streams and springs originating on or near the Arbuckle-Simpson aquifer, south-central Oklahoma.

8. Areas of surface and subsurface watersheds for selected streams and springs on the eastern Arbuckle-Simpson aquifer, south-central Oklahoma.

9. Quarterly recharge rates calculated for watersheds upstream from selected streamgages on the Arbuckle-Simpson aquifer, south-central Oklahoma.

10. Storage coefficients calculated from streamflows and change in water stored in subsurface watersheds, June 22, 2006, through September 8, 2006 .

11. Storage coefficients determined as the ratio of recharge to increase in height of the potentiometric surface in wells equipped with pressure transducers and data loggers from July 1, 2004, to May 6, 2006.

12. Reported groundwater-use statistics for the eastern Arbuckle-Simpson aquifer, south-central Oklahoma, 1964-2008.

13. Average annual reported groundwater use by type for the eastern Arbuckle-Simpson aquifer, south-central Oklahoma, 1964-2008

14. Thickness of layers in the eastern Arbuckle-Simpson aquifer, south-central Oklahoma, MODFLOW model. 
15. Area, thickness, and volume statistics calculated from the geologic framework and groundwater-flow models of the eastern Arbuckle-Simpson aquifer, south-central Oklahoma

16. Streamflow measurements in the Arbuckle-Simpson aquifer, south-central Oklahoma, study area on August 14, 1995

17. Eastern Arbuckle-Simpson aquifer, south-central Oklahoma, MODFLOW model parameters from the steady-state calibration

18. Simulated streamflows compared to streamflow measurements on August 14, 1995.

19. Area-weighted average annual recharge for the eastern Arbuckle-Simpson aquifer, south-central Oklahoma, MODFLOW model for water years 2004-8

20. Monthly water budget for the eastern Arbuckle-Simpson aquifer, south-central Oklahoma, MODFLOW model...

21. Five-year total and average annual groundwater withdrawals for the calibrated transient model and simulations of withdrawals distributed as an equal proportionate share

22. Depletion of average flows for water years 2004-8 for Blue River near Connerville, Oklahoma, and Pennington Creek near Reagan, Okla., simulated by the eastern Arbuckle-Simpson aquifer, MODFLOW model based on groundwater withdrawals distributed as an equal proportionate share.

23. Depletion of 75-percent exceedance of streamflow for water years 2004-8 for Blue River near Connerville, Oklahoma, and Pennington Creek near Reagan, Okla., simulated by the eastern Arbuckle-Simpson aquifer MODFLOW model with groundwater withdrawals distributed as an equal proportionate share

24. Five-year average base flow for water years 2004-8 and depletion of 5 -year average base flow for all streams simulated by the eastern Arbuckle-Simpson aquifer, south-central Oklahoma, MODFLOW model based on simulations of groundwater withdrawals distributed as an equal proportionate share.

25. Five-year average base flow for water years 2004-8 and depletion of 5-year average base flow for all streams simulated by the eastern Arbuckle-Simpson aquifer, south-central Oklahoma, MODFLOW model based on simulations of concentrated withdrawals of groundwater.

26. Five-year average base flow for water years 2004-8 and depletion of 5-year average base flow for all streams simulated by the eastern Arbuckle-Simpson aquifer, south-central Oklahoma, MODFLOW model based on a simulation of no groundwater withdrawals 


\section{Conversion Factors}

This report contains a mixture of inch/pound and System International (SI) units. Measurements and calculations are reported in units appropriate to the subject under discussion and not converted to one system of units.

Inch/Pound to SI

\begin{tabular}{|c|c|c|}
\hline Multiply & By & To obtain \\
\hline \multicolumn{3}{|c|}{ Length } \\
\hline inch (in.) & 2.54 & centimeter $(\mathrm{cm})$ \\
\hline inch (in.) & 25.4 & millimeter (mm) \\
\hline foot $(\mathrm{ft})$ & 0.3048 & meter $(\mathrm{m})$ \\
\hline mile (mi) & 1.609 & kilometer $(\mathrm{km})$ \\
\hline yard (yd) & 0.9144 & meter $(\mathrm{m})$ \\
\hline \multicolumn{3}{|c|}{ Area } \\
\hline acre & 4,047 & square meter $\left(\mathrm{m}^{2}\right)$ \\
\hline acre & 0.4047 & hectare (ha) \\
\hline acre & 0.4047 & square hectometer $\left(\mathrm{hm}^{2}\right)$ \\
\hline acre & 0.004047 & square kilometer $\left(\mathrm{km}^{2}\right)$ \\
\hline square foot $\left(\mathrm{ft}^{2}\right)$ & 929.0 & square centimeter $\left(\mathrm{cm}^{2}\right)$ \\
\hline square foot $\left(\mathrm{ft}^{2}\right)$ & 0.09290 & square meter $\left(\mathrm{m}^{2}\right)$ \\
\hline square inch $\left(\mathrm{in}^{2}\right)$ & 6.452 & square centimeter $\left(\mathrm{cm}^{2}\right)$ \\
\hline $\begin{array}{l}\text { section ( } 640 \text { acres or } 1 \text { square } \\
\text { mile) }\end{array}$ & 259.0 & square hectometer $\left(\mathrm{hm}^{2}\right)$ \\
\hline square mile $\left(\mathrm{mi}^{2}\right)$ & 259.0 & hectare (ha) \\
\hline square mile $\left(\mathrm{mi}^{2}\right)$ & 2.590 & square kilometer $\left(\mathrm{km}^{2}\right)$ \\
\hline \multicolumn{3}{|c|}{ Volume } \\
\hline gallon (gal) & 3.785 & liter (L) \\
\hline gallon (gal) & 0.003785 & cubic meter $\left(\mathrm{m}^{3}\right)$ \\
\hline gallon (gal) & 3.785 & cubic decimeter $\left(\mathrm{dm}^{3}\right)$ \\
\hline million gallons (Mgal) & 3,785 & cubic meter $\left(\mathrm{m}^{3}\right)$ \\
\hline cubic foot $\left(\mathrm{ft}^{3}\right)$ & 28.32 & cubic decimeter $\left(\mathrm{dm}^{3}\right)$ \\
\hline cubic foot $\left(\mathrm{ft}^{3}\right)$ & 0.02832 & cubic meter $\left(\mathrm{m}^{3}\right)$ \\
\hline cubic yard $\left(\mathrm{yd}^{3}\right)$ & 0.7646 & cubic meter $\left(\mathrm{m}^{3}\right)$ \\
\hline acre-foot (acre-ft) & 1,233 & cubic meter $\left(\mathrm{m}^{3}\right)$ \\
\hline acre-foot (acre-ft) & 0.001233 & cubic hectometer $\left(\mathrm{hm}^{3}\right)$ \\
\hline \multicolumn{3}{|c|}{ Flow rate } \\
\hline acre-foot per day (acre-ft/d) & 0.01427 & cubic meter per second $\left(\mathrm{m}^{3} / \mathrm{s}\right)$ \\
\hline acre-foot per year (acre-ft/yr) & 1,233 & cubic meter per year $\left(\mathrm{m}^{3} / \mathrm{yr}\right)$ \\
\hline acre-foot per year (acre-ft/yr) & 0.001233 & cubic hectometer per year $\left(\mathrm{hm}^{3} / \mathrm{yr}\right)$ \\
\hline gallon per minute (gal/min) & 0.06309 & liter per second $(\mathrm{L} / \mathrm{s})$ \\
\hline gallon per day (gal/d) & 0.003785 & cubic meter per day $\left(\mathrm{m}^{3} / \mathrm{d}\right)$ \\
\hline million gallons per day (Mgal/d) & 0.04381 & cubic meter per second $\left(\mathrm{m}^{3} / \mathrm{s}\right)$ \\
\hline inch per year (in/yr) & 25.4 & millimeter per year (mm/yr) \\
\hline mile per hour $(\mathrm{mi} / \mathrm{h})$ & 1.609 & kilometer per hour $(\mathrm{km} / \mathrm{h})$ \\
\hline
\end{tabular}




\begin{tabular}{|c|c|c|}
\hline Multiply & By & To obtain \\
\hline \multicolumn{3}{|c|}{ Specific capacity } \\
\hline \multicolumn{3}{|l|}{ gallon per minute per foot } \\
\hline$[(\mathrm{gal} / \mathrm{min}) / \mathrm{ft})]$ & 0.2070 & liter per second per meter $[(\mathrm{L} / \mathrm{s}) / \mathrm{m}]$ \\
\hline \multicolumn{3}{|c|}{ Hydraulic conductivity } \\
\hline foot per day (ft/d) & 0.3048 & meter per day $(\mathrm{m} / \mathrm{d})$ \\
\hline \multicolumn{3}{|c|}{ Hydraulic gradient } \\
\hline foot per mile (ft/mi) & 0.1894 & meter per kilometer $(\mathrm{m} / \mathrm{km})$ \\
\hline \multicolumn{3}{|c|}{ Transmissivity* } \\
\hline foot squared per day $\left(\mathrm{ft}^{2} / \mathrm{d}\right)$ & 0.09290 & meter squared per day $\left(\mathrm{m}^{2} / \mathrm{d}\right)$ \\
\hline \multicolumn{3}{|c|}{ Leakance } \\
\hline foot per day per foot $[(\mathrm{ft} / \mathrm{d}) / \mathrm{ft}]$ & 1 & meter per day per meter \\
\hline inch per year per foot $[(\mathrm{in} / \mathrm{yr}) / \mathrm{ft}]$ & 83.33 & $\begin{array}{l}\text { millimeter per year per meter } \\
\qquad[(\mathrm{mm} / \mathrm{yr}) / \mathrm{m}]\end{array}$ \\
\hline
\end{tabular}

SI to Inch/Pound

\begin{tabular}{|c|c|c|}
\hline Multiply & By & To obtain \\
\hline \multicolumn{3}{|c|}{ Length } \\
\hline centimeter $(\mathrm{cm})$ & 0.3937 & inch (in.) \\
\hline millimeter (mm) & 0.03937 & inch (in.) \\
\hline meter $(\mathrm{m})$ & 3.281 & foot $(\mathrm{ft})$ \\
\hline kilometer (km) & 0.6214 & mile (mi) \\
\hline meter $(\mathrm{m})$ & 1.094 & yard (yd) \\
\hline \multicolumn{3}{|c|}{ Area } \\
\hline square meter $\left(\mathrm{m}^{2}\right)$ & 0.0002471 & acre \\
\hline hectare (ha) & 2.471 & acre \\
\hline square hectometer $\left(\mathrm{hm}^{2}\right)$ & 2.471 & acre \\
\hline square kilometer $\left(\mathrm{km}^{2}\right)$ & 247.1 & acre \\
\hline square centimeter $\left(\mathrm{cm}^{2}\right)$ & 0.001076 & square foot $\left(\mathrm{ft}^{2}\right)$ \\
\hline square meter $\left(\mathrm{m}^{2}\right)$ & 10.76 & square foot $\left(\mathrm{ft}^{2}\right)$ \\
\hline square hectometer $\left(\mathrm{hm}^{2}\right)$ & 0.003861 & section (640 acres or 1 square mile) \\
\hline hectare (ha) & 0.003861 & square mile $\left(\mathrm{mi}^{2}\right)$ \\
\hline square kilometer $\left(\mathrm{km}^{2}\right)$ & 0.3861 & square mile $\left(\mathrm{mi}^{2}\right)$ \\
\hline \multicolumn{3}{|c|}{ Volume } \\
\hline liter $(\mathrm{L})$ & 33.82 & ounce, fluid (fl. oz) \\
\hline liter $(\mathrm{L})$ & 2.113 & $\operatorname{pint}(\mathrm{pt})$ \\
\hline liter $(\mathrm{L})$ & 1.057 & quart (qt) \\
\hline liter $(\mathrm{L})$ & 0.2642 & gallon (gal) \\
\hline cubic meter $\left(\mathrm{m}^{3}\right)$ & 264.2 & gallon (gal) \\
\hline cubic meter $\left(\mathrm{m}^{3}\right)$ & 0.0002642 & million gallons (Mgal) \\
\hline cubic meter $\left(\mathrm{m}^{3}\right)$ & 35.31 & cubic foot $\left(\mathrm{ft}^{3}\right)$ \\
\hline cubic meter $\left(\mathrm{m}^{3}\right)$ & 1.308 & cubic yard $\left(\mathrm{yd}^{3}\right)$ \\
\hline cubic meter $\left(\mathrm{m}^{3}\right)$ & 0.0008107 & acre-foot (acre-ft) \\
\hline
\end{tabular}




\begin{tabular}{|c|c|c|}
\hline Multiply & By & To obtain \\
\hline \multicolumn{3}{|c|}{ Flow rate } \\
\hline cubic meter per second $\left(\mathrm{m}^{3} / \mathrm{s}\right)$ & 70.07 & acre-foot per day (acre-ft/d) \\
\hline cubic meter per year $\left(\mathrm{m}^{3} / \mathrm{yr}\right)$ & 0.000811 & acre-foot per year (acre-ft/yr) \\
\hline cubic meter per second $\left(\mathrm{m}^{3} / \mathrm{s}\right)$ & 35.31 & cubic foot per second $\left(\mathrm{ft}^{3} / \mathrm{s}\right)$ \\
\hline liter per second $(\mathrm{L} / \mathrm{s})$ & 15.85 & gallon per minute (gal/min) \\
\hline cubic meter per day $\left(\mathrm{m}^{3} / \mathrm{d}\right)$ & 264.2 & gallon per day (gal/d) \\
\hline cubic meter per second $\left(\mathrm{m}^{3} / \mathrm{s}\right)$ & 22.83 & million gallons per day (Mgal/d) \\
\hline millimeter per year $(\mathrm{mm} / \mathrm{yr})$ & 0.03937 & inch per year (in/yr) \\
\hline \multicolumn{3}{|c|}{ Specific capacity } \\
\hline $\begin{array}{l}\text { liter per second per meter } \\
\qquad(\mathrm{L} / \mathrm{s}) / \mathrm{m}]\end{array}$ & 4.831 & $\begin{array}{l}\text { gallon per minute per foot [(gal/ } \\
\min ) / \mathrm{ft}]\end{array}$ \\
\hline \multicolumn{3}{|c|}{ Hydraulic conductivity } \\
\hline meter per day $(\mathrm{m} / \mathrm{d})$ & 3.281 & foot per day (ft/d) \\
\hline \multicolumn{3}{|c|}{ Hydraulic gradient } \\
\hline meter per kilometer $(\mathrm{m} / \mathrm{km})$ & 5.27983 & foot per mile (ft/mi) \\
\hline \multicolumn{3}{|c|}{ Transmissivity* } \\
\hline meter squared per day $\left(\mathrm{m}^{2} / \mathrm{d}\right)$ & 10.76 & foot squared per day $\left(\mathrm{ft}^{2} / \mathrm{d}\right)$ \\
\hline \multicolumn{3}{|c|}{ Leakance } \\
\hline meter per day per meter $[(\mathrm{m} / \mathrm{d}) / \mathrm{m}]$ & 1 & foot per day per foot $[(\mathrm{ft} / \mathrm{d}) / \mathrm{ft}]$ \\
\hline
\end{tabular}

Vertical coordinate information is referenced to the North American Vertical Datum of 1988 (NAVD 88). The NAVD 88 replaced the National Geodetic Vertical Datum of 1929 (NGVD 29), previously known as the Sea Level Datum of 1929.

Horizontal coordinate information, unless otherwise specified, is referenced to the North American Datum of 1983 (NAD 83).

Altitude, as used in this report, refers to distance above the vertical datum.

Temperature in degrees Celsius $\left({ }^{\circ} \mathrm{C}\right)$ may be converted to degrees Fahrenheit $\left({ }^{\circ} \mathrm{F}\right)$ as follows:

${ }^{\circ} \mathrm{F}=\left(1.8 x^{\circ} \mathrm{C}\right)+32$

Temperature in degrees Fahrenheit $\left({ }^{\circ} \mathrm{F}\right)$ may be converted to degrees Celsius $\left({ }^{\circ} \mathrm{C}\right)$ as follows:

${ }^{\circ} \mathrm{C}=\left({ }^{\circ} \mathrm{F}-32\right) / 1.8$

Water year is the 12-month period October 1 through September 30 , designated by the calendar year in which the water year ends.

Concentrations of chemical constituents in water are given in milligrams per liter (mg/L).

*Transmissivity: The standard unit for transmissivity is cubic foot per day per square foot times foot of aquifer thickness $\left[\left(\mathrm{ft}^{3} / \mathrm{d}\right) / \mathrm{ft}^{2}\right] \mathrm{ft}$. In this report, the mathematically reduced form, foot squared per day $\left(\mathrm{ft}^{2} / \mathrm{d}\right)$, is used for convenience. 


\title{
Hydrogeology and Simulation of Groundwater Flow in the Arbuckle-Simpson Aquifer, South-Central Oklahoma
}

\author{
By Scott Christenson, ${ }^{1}$ Noel I. Osborn, ${ }^{2}$ Christopher R. Neel, ${ }^{2}$ Jason R. Faith, ${ }^{1}$ Charles D. Blome, ${ }^{1}$ \\ James Puckette, ${ }^{3}$ and Michael P. Pantea ${ }^{1}$
}

\section{Abstract}

The Arbuckle-Simpson aquifer in south-central Oklahoma provides water for public supply, farms, mining, wildlife conservation, recreation, and the scenic beauty of springs, streams, and waterfalls. Proposed development of water supplies from the aquifer led to concerns that largescale withdrawals of water would cause decreased flow in rivers and springs, which in turn could result in the loss of water supplies, recreational opportunities, and aquatic habitat. The Oklahoma Water Resources Board, in collaboration with the Bureau of Reclamation, the U.S. Geological Survey, Oklahoma State University, and the University of Oklahoma, studied the aquifer to provide the Oklahoma Water Resources Board the scientific information needed to determine the volume of water that could be withdrawn while protecting springs and streams. The U.S. Geological Survey, in cooperation with the Oklahoma Water Resources Board, did a study to describe the hydrogeology and simulation of groundwater flow of the aquifer.

The outcrop of the Arbuckle-Simpson aquifer covers an area of about 520 square miles in Carter, Coal, Johnston, Murray, and Pontotoc Counties. Three subdivisions of the aquifer outcrop were designated for this study: the eastern, central, and western Arbuckle-Simpson aquifer. This study emphasized the eastern Arbuckle-Simpson aquifer because it is the largest part of the aquifer by area and volume; most groundwater withdrawals are from the eastern ArbuckleSimpson aquifer; and the largest (by flow) streams and springs sourced from the aquifer are on the eastern Arbuckle-Simpson aquifer.

The aquifer lies in an uplifted area commonly referred to as the Arbuckle Mountains, which is characterized by great thicknesses of mostly carbonate rocks, uplifts, folded structures, and large fault displacements. The

\footnotetext{
${ }^{1}$ U.S. Geological Survey.

${ }^{2}$ Oklahoma Water Resources Board, Oklahoma City, Oklahoma.

${ }^{3}$ Oklahoma State University, Stillwater, Oklahoma.
}

Arbuckle-Simpson aquifer is contained in three major rock units of Late Cambrian to Middle Ordovician age: the Timbered Hills, Arbuckle, and Simpson Groups. The aquifer is underlain by low-permeability Cambrian and Proterozoic igneous and metamorphic rocks, and is confined above by younger sedimentary rocks of various ages in areas where the top of the aquifer dips below the surface. The major part of the Arbuckle-Simpson aquifer is the Arbuckle Group, which consists of as much as 6,700 feet of limestone in the western Arbuckle-Simpson aquifer, but which thins to an estimated 3,000 feet of predominantly dolostone in the eastern Arbuckle-Simpson aquifer. Water is obtained from cavities, solution channels, fractures, and intercrystalline porosity in the limestone and dolostone. The overlying Simpson Group, consisting of sandstones, shales, and limestones, is as much as 2,300 feet thick in the western Arbuckle-Simpson aquifer, but generally is less than 1,000 feet thick in the eastern aquifer. Water in the Simpson Group is stored primarily in pore spaces between the sand grains in the sandstones.

A digital, three-dimensional geologic framework model was constructed to define the geometric relations of fault blocks and subsurface rock units across complex fault zones of the eastern Arbuckle-Simpson aquifer. Geologic data for the model were obtained from 126 drill holes; stratigraphic contacts and faults defined from a digitized version of the surface geologic map; and fault geometry, stratigraphic thickness, and information compiled from geologic and hydrogeologic reports and maps.

Groundwater in the aquifer moves from areas of high head (altitude) to areas of low head along streams and springs. The potentiometric surface in the eastern ArbuckleSimpson aquifer generally slopes from a topographic high from northwest to the southeast, indicating that regional groundwater flow is predominantly toward the southeast. Freshwater is known to extend beyond the aquifer outcrop near the City of Sulphur, Oklahoma, and Chickasaw National Recreation Area, where groundwater flows west from the outcrop of the eastern Arbuckle-Simpson aquifer and becomes confined beneath younger geologic units. The depth of fresh groundwater in the outcrop area is not known, but the few deep wells drilled in the outcrop area do not produce saline 
water. A test well drilled to a depth of 1,820 feet as part of this study produced freshwater.

The primary source of groundwater in the ArbuckleSimpson aquifer is diffuse recharge from precipitation in the outcrop area. Groundwater discharge from the aquifer is predominantly to streams and springs. Groundwater discharge from the Arbuckle-Simpson aquifer maintains base flow to perennial streams overlying the aquifer, including Blue River, Pennington Creek, Mill Creek, Travertine Creek, Delaware Creek, and Honey Creek. Many springs discharge from the aquifer, including Byrds Mill Spring, the primary water supply for the City of Ada, and springs in Chickasaw National Recreation Area. A small amount of groundwater discharge is to groundwater withdrawal wells. Most groundwater withdrawals are in the eastern part of the aquifer, where average annual reported groundwater use from 1964 through 2008 was 4,299 acre-feet. Sixty-three percent of the groundwater withdrawal was for public water-supply systems.

Hydraulic properties were calculated by using several methods, including an aquifer test and several regional methods. Transmissivity from the analytical solution analysis of the aquifer test was 12,000 feet squared per day. Storage coefficients calculated by regional methods ranged from 0.00211 to 0.07475 .

A MODFLOW groundwater-flow model was developed to simulate discharge to streams and springs in the eastern Arbuckle-Simpson aquifer. Horizontal discretization in the model was 200 meters ( 656 feet) by 200 meters (656 feet), and six layers were used to represent the aquifer over a model area of 1,002 square kilometers (387.1 square miles). The digital three-dimensional geologic framework model provided the geologic data for the MODFLOW groundwaterflow model. The recharge rate, calculated from streamflow data, was distributed over four recharge zones based on the geology at the land surface. Groundwater discharge to streams was simulated as drains. The model was calibrated by using the parameter-estimation process in MODFLOW to steadystate conditions by using a set of synoptic head and flow observations from August 1995. Increasing model vertical hydraulic conductivity beneath Travertine Creek and other creeks at the boundary between freshwater and saline water flow systems resulted in an improved fit between observed and simulated streamflows.

Transient simulations, using daily recharge and wateruse data, were accomplished by running the model with 1-day stress periods for the 5-water-year time period starting October 1, 2003, through September 30, 2008, corresponding to water years 2004 through 2008. Area-weighted annual recharge rates applied to the model domain averaged 5.58 inches (142 millimeters) per year for water years 2004-8, and ranged from 2.57 inches (65.3 millimeters) in water year 2006 to 11.61 inches (295 millimeters) in water year 2007. A specific storage of 0.000008 per meter was used for all transient simulations, which corresponds to a regional storage coefficient of 0.008 . Because of concerns that large-scale withdrawals of water from the Arbuckle-Simpson aquifer would cause decreased streamflow in rivers and springs, the model was optimized to simulate the effects on Blue River and Pennington Creek, the streams with the largest flows in the eastern aquifer. Total gaged flow for the 5-water-year period for Blue River near Connerville was 336,712 acre-feet, and the total simulated flow was 336,946 acre-feet. Total gaged flow for the 5-wateryear period for Pennington Creek near Reagan was 155,720 acre-feet, and the total simulated flow was 154,699 acre-feet.

Steady-state and transient models were used to evaluate changes in stream and spring flows associated with increased water demands and development. Three simulations of distributed withdrawals were tested, allocating groundwater withdrawals as equal proportionate shares of $0.125,0.250$, and 0.392 (acre-feet/acre)/year (0.392 (acre-feet/acre)/year is equivalent to the average recharge rate of 4.7 inches per year for the Arbuckle-Simpson aquifer reported in a previous study). Simulated depletion of average streamflow for water years $2004-8$ at the Blue River near Connerville, Oklahoma, streamgage was 17.62 percent for a distributed withdrawal of 0.125 (acre-feet/acre)/year, 35.63 percent for a distributed withdrawal of 0.250 (acre-feet/acre)/year, and 53.49 percent for a distributed withdrawal of 0.392 (acre-feet/acre)/year. Simulated depletion of average streamflow for water years 2004-8 at the Pennington Creek near Reagan, Oklahoma, streamgage was 18.18 percent for a distributed withdrawal of 0.125 (acre-feet/acre)/year, 36.22 percent for a distributed withdrawal of 0.250 (acre-feet/acre)/year, and 56.59 percent for a distributed withdrawal of 0.392 (acre-feet/acre)/year. The eastern Arbuckle-Simpson aquifer groundwater-flow model was used to estimate the current (2011) streamflow depletion caused by the existing groundwater withdrawals for water years 2004-8. The model-simulated average base flow was 4.1 percent greater when groundwater withdrawals were removed from the simulation. The model also showed that increasing withdrawal of groundwater from the aquifer will result in fewer locations where groundwater is discharging to streams and springs.

\section{Introduction}

The Arbuckle-Simpson aquifer in south-central Oklahoma (fig. 1) provides water for public supply, farms, mining, wildlife conservation, recreation, and the scenic beauty of springs, streams, and waterfalls. Groundwater use from the aquifer is small, with an average annual reported use of only 4,510 acre-feet (acre-ft) from 1964 to 2008. However, most of the reported use is from the eastern part of the aquifer with an average of 4,299 acre-ft over the same timeframe, of which 63 percent is for public supplies. The eastern part of the aquifer provides drinking water to about 39,000 people in the Cities of Ada and Sulphur, Oklahoma, and the surrounding area. Water from most wells completed in the aquifer is suitable for all regulated uses, with a median dissolved solids concentration of 347 milligrams per liter (Christenson and others, 2009). 


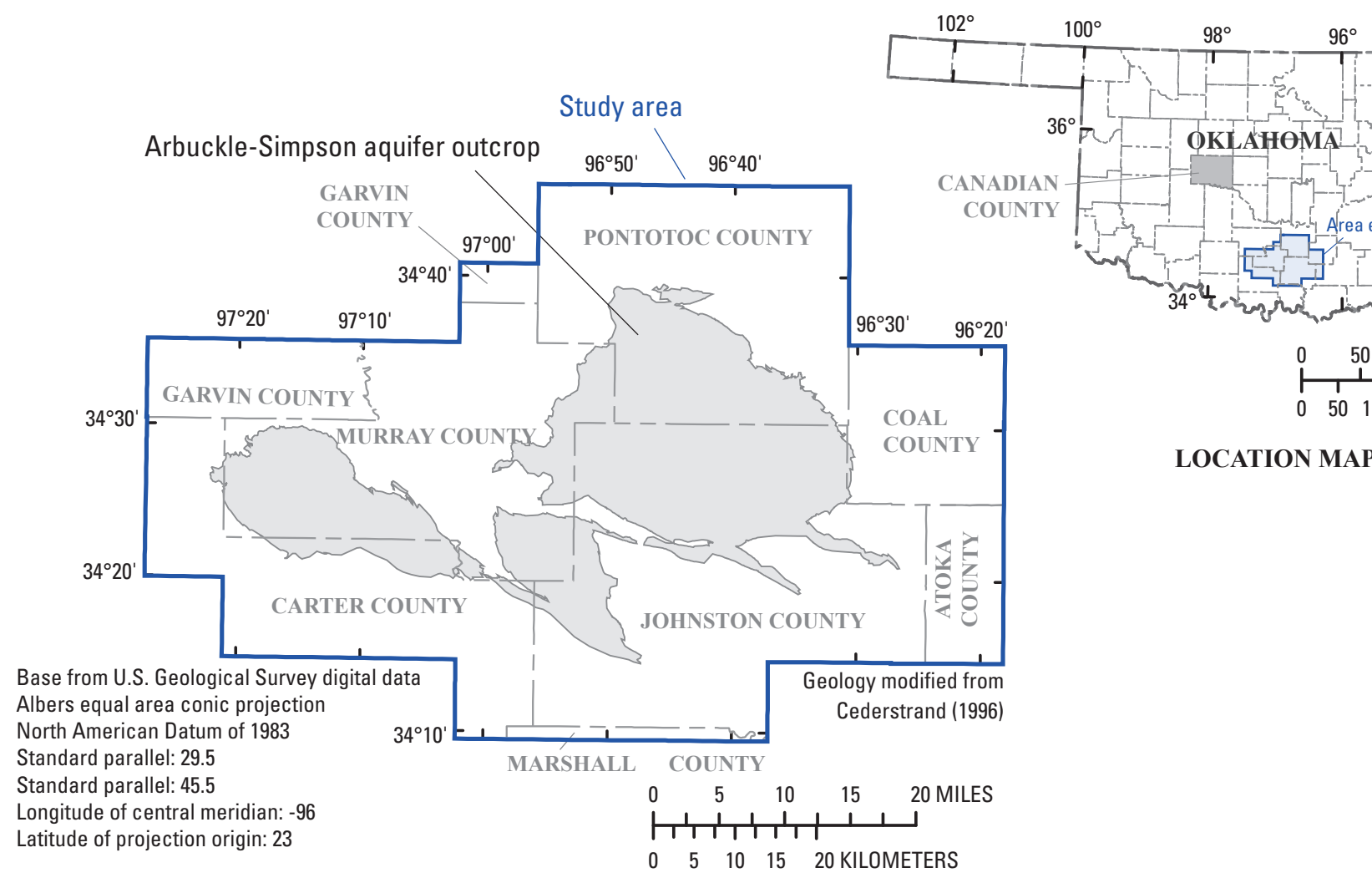

Figure 1. The Arbuckle-Simpson aquifer outcrop, south-central Oklahoma.

The outcrop of the aquifer has an area of about 520 square miles $\left(\mathrm{mi}^{2}\right)$ and is in Carter, Coal, Johnston, Murray, and Pontotoc Counties (fig. 2). The study area was defined to extend beyond the perimeter of the aquifer outcrop because fresh groundwater originating as recharge on the outcrop flows beyond the outcrop beneath shallower geologic units at some locations, and geologic and hydrologic data outside the aquifer outcrop were useful in studying the aquifer. The study area was $2,016 \mathrm{mi}^{2}$ (fig. 2).

Groundwater discharge from the aquifer maintains base flow to Blue River, (Byrds) Mill Creek, Delaware Creek, Honey Creek, Mill Creek, Oil Creek, Pennington Creek, Rock Creek, Travertine Creek, and many small streams [two streams named "Mill Creek" are in the study area; the stream that consists largely of discharge from Byrds Mill Spring is referred to as (Byrds) Mill Creek herein to differentiate the two streams (Oklahoma Water Resources Board, 2007)]. Many springs, including Byrds Mill Spring (the primary water supply for the City of Ada) and the springs in Chickasaw National Recreation Area, discharge from the aquifer.

In search of future water supplies, the Central Oklahoma Water Resource Authority, consisting primarily of communities in Canadian County, Oklahoma, proposed in 2002 to purchase water rights for the Arbuckle-Simpson aquifer, drill wells, and build an 88-mile (mi) pipeline from the Arbuckle-Simpson aquifer to Canadian County in central
Oklahoma (Oklahoma Water Resources Board, 2003, p. 1). In Oklahoma, groundwater is considered to be private property that belongs to the overlying surface property owner. Thus, the proposed withdrawal and transfer of water by the Central Oklahoma Water Resource Authority was considered by the State of Oklahoma to be a permissible use of groundwater. However, local residents, citizens' groups, and the National Park Service were concerned that large-scale withdrawals of water from the Arbuckle-Simpson aquifer would cause decreased flow in rivers and springs, which in turn could result in the loss of water supplies, recreational opportunities, and aquatic habitat. Many protests were filed with the Oklahoma Water Resources Board (OWRB) as a result of the proposed water transfer.

The Oklahoma Senate, in response to these concerns, passed Senate Bill 288 (2003), which imposed a moratorium on the issuance of any temporary groundwater permit for municipal or public water-supply use outside of any county that overlies a "sensitive sole source groundwater basin" (Oklahoma Water Resources Board, 2003, p. 1). The term "groundwater basin" is defined by the State of Oklahoma as "a distinct underground body of water overlain by contiguous land having substantially the same geological and hydrological characteristics and yield capabilities." The Arbuckle-Simpson aquifer is considered a "sensitive sole source groundwater basin" because the U.S. Environmental Protection Agency 
EXPLANATION

Aquifer outcrop

Chickasaw National Recreation Area

Boundary of study area

Boundary of township

- Well

$\Delta$ Station

- Spring

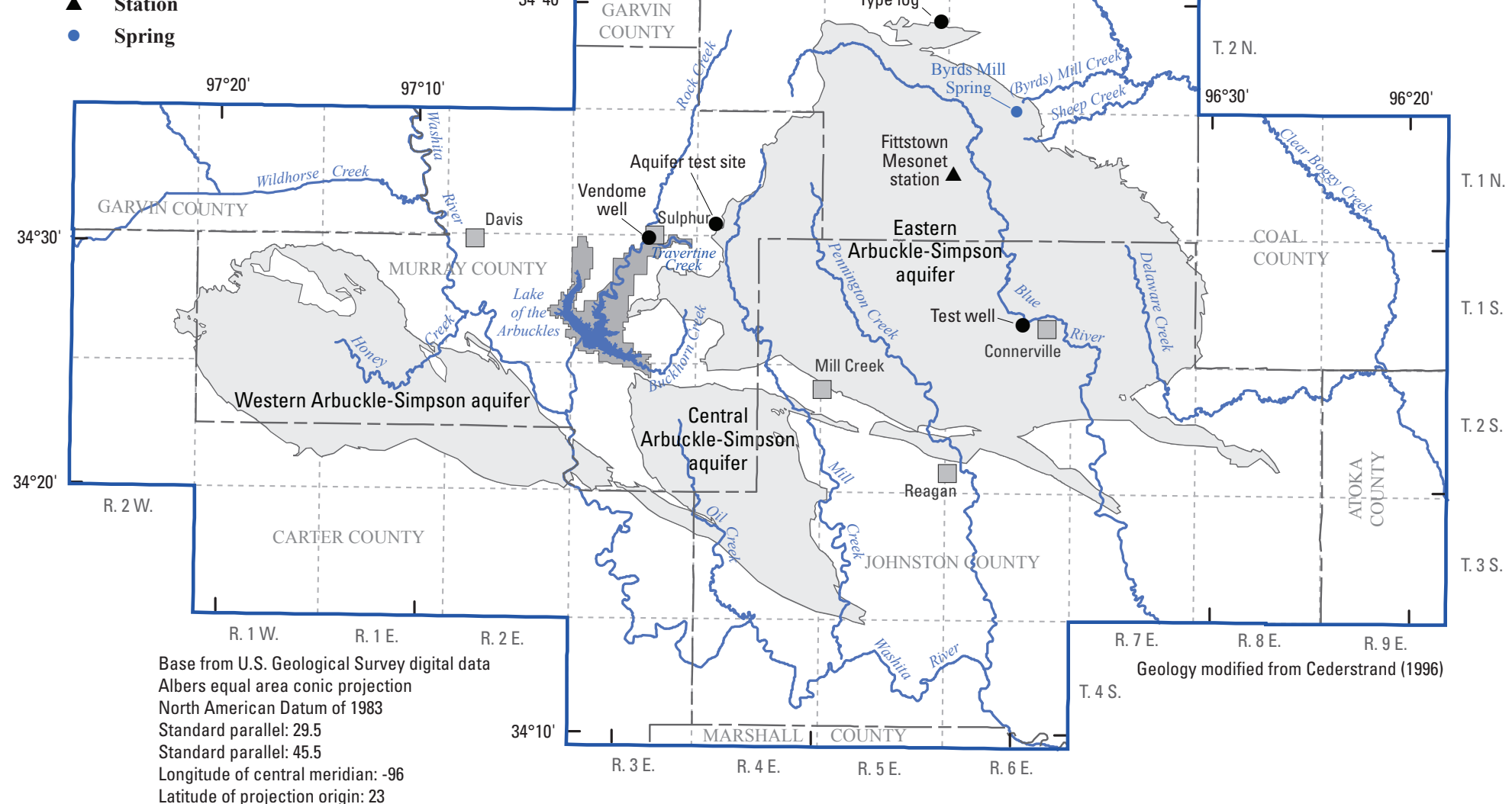

tatude of projection origin: 23

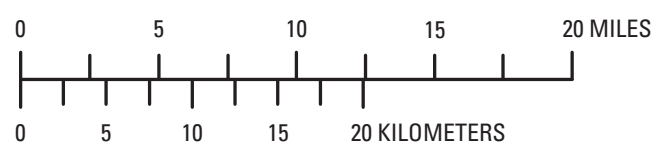

Figure 2. Geographic features of the Arbuckle-Simpson aquifer study area, south-central Oklahoma. 
designated the eastern Arbuckle-Simpson aquifer as a "Sole Source Aquifer" in 1989 (National Archives and Records Administration, 1989). The Arbuckle-Simpson aquifer was the only designated "Sole Source Aquifer" in Oklahoma as of 2011. Senate Bill 288 (2003) states that the moratorium will remain in effect until the Oklahoma Water Resources Board completes a hydrological study and approves a maximum annual yield (the total amount of water that can be withdrawn from a specific groundwater basin in any year) of a sensitive sole source groundwater basin that will ensure that any permit for the removal of water from the groundwater basin will not reduce the natural flow of water from springs or streams emanating from the basin.

Accordingly, the Oklahoma Water Resources Board, in collaboration with the Bureau of Reclamation, the U.S. Geological Survey (USGS), Oklahoma State University, and the University of Oklahoma, managed a comprehensive multiyear study of the aquifer (Oklahoma Water Resources Board, 2003, p. 2). The purpose of the study, known as the "Arbuckle-Simpson Hydrology Study," was to provide the Oklahoma Water Resources Board with the scientific information needed to determine the volume of water that could be withdrawn from the aquifer while protecting springs and streams. Specific objectives of the Arbuckle-Simpson Hydrology Study were as follows:

1. Characterize the Arbuckle-Simpson aquifer in terms of geologic setting, aquifer boundaries, hydraulic properties, water levels, groundwater flow, recharge, discharge, and water budget.

2. Characterize the area's surface hydrology, including stream and spring discharge, runoff, base flow, and the relationship of surface water to groundwater.

3. Construct a digital groundwater/surface-water-flow model of the Arbuckle-Simpson aquifer system for use in evaluating the allocation of water rights and simulating management options.

4. Determine the chemical quality of the aquifer and principal streams, identify potential sources of natural contamination, and delineate areas of the aquifer that are most vulnerable to contamination.

5. Construct network stream models of the principal stream systems for use in the allocation of water rights.

6. Propose water management options, consistent with state water laws, that address water rights issues, the potential impacts of pumping on springs and stream base flows, water quality, and water supply development.

Numerous studies were performed by researchers participating in the Arbuckle-Simpson Hydrology Study to meet these six objectives. The U.S. Geological Survey, in cooperation with the Oklahoma Water Resources Board, did a study to describe the hydrogeology and simulation of groundwater flow of the Arbuckle-Simpson aquifer in partial fulfillment of objectives 1, 2, 3, and 6 .

\section{Purpose and Scope}

This report describes the hydrogeology of the ArbuckleSimpson aquifer in south-central Oklahoma and the development and application of numerical models to simulate groundwater flow in the eastern part of the Arbuckle-Simpson aquifer, completed as part of the Arbuckle-Simpson Hydrology Study. This report includes discussion of (1) the geologic history of the aquifer; (2) the hydrostratigraphy, which includes the lithology, stratigraphy, and tectonic geology of the aquifer; (3) a three-dimensional geologic framework model of the eastern Arbuckle-Simpson aquifer and overlying and underlying geologic units; (4) climate of the study area; (5) streamgage data and streamflow measurements for major and minor streams in the study area; (6) hydraulic properties of and recharge to the aquifer; (7) groundwater withdrawal rates from the aquifer; and (8) the development of numerical models that simulate groundwater flow in the aquifer. The hydrology and hydraulic properties of the aquifer are strongly influenced by geology; therefore, a detailed geologic description of the aquifer is provided as part of this report.

The hydrogeologic study and groundwater-flow model were focused on the eastern Arbuckle-Simpson aquifer because (1) the data needed to build the model are sparse in the western and central Arbuckle-Simpson aquifer, (2) the eastern Arbuckle-Simpson aquifer is the largest part of the aquifer by area and volume, (3) most of the current (2011) groundwater withdrawals from the aquifer are from the eastern Arbuckle-Simpson aquifer, and (4) the largest (by flow) streams and springs sourced from the aquifer are on the eastern Arbuckle-Simpson aquifer. Although the study emphasized the eastern Arbuckle-Simpson aquifer, understanding of the eastern part of the aquifer requires studying the entire aquifer, especially with respect to the geology.

Steady-state and transient groundwater-flow models were developed to evaluate changes in stream and spring flows associated with increased water demands and development. The models were developed and calibrated on the basis of information collected during this and previous studies. Many of these datasets were compiled by and in collaboration with the staff of the Oklahoma Water Resources Board, scientists from the U.S. Geological Survey, and professors and students from Oklahoma State University and the University of Oklahoma. The U.S. Geological Survey modular threedimensional finite-difference groundwater-flow modeling code, MODFLOW-2000 (Harbaugh and others, 2000), was used to simulate the aquifer. Results of several simulations of distributed groundwater withdrawals are described, as are several test-of-concept simulations. 
Hydrogeology and Simulation of Groundwater Flow in the Arbuckle-Simpson Aquifer, South-Central Oklahoma

\section{Hydrogeology}

The term "hydrogeology" is sometimes used narrowly in describing the study of the movement of groundwater through aquifers. The term is used in this report in a broad sense to include many aspects of the geology and hydrology of the Arbuckle-Simpson aquifer. The discussion of the geology of the Arbuckle-Simpson aquifer in this report is comprehensive because the hydrology and hydraulic properties of the aquifer are strongly influenced by geology. The information in this section was used to conceptualize the groundwater-flow system for development of the groundwater-flow model described in the Simulation of Groundwater Flow section.

The Arbuckle-Simpson aquifer crops out in an area of about $520 \mathrm{mi}^{2}$ (fig. 2). For this study, the aquifer outcrop consists of contiguous, regional exposures of the rock units (Timbered Hills, Arbuckle, and Simpson Groups) comprising the aquifer. Excluded from the aquifer outcrop are discontinuous, local exposures of these units. For example, discontinuous exposures of the Simpson Group west of the town of Davis, Oklahoma (fig. 2), are excluded from the aquifer outcrop (fig. 3).

Three subdivisions of the aquifer outcrop were designated for this study: the eastern, central, and western ArbuckleSimpson aquifer (fig. 2). This terminology is equivalent to the terms "Hunton anticline" (eastern Arbuckle-Simpson aquifer), "Tishomingo anticline" (central Arbuckle-Simpson aquifer), and "Arbuckle anticline" (western Arbuckle-Simpson aquifer) used in some recent publications, for example, Christenson and others (2009). The designations eastern, central, and western Arbuckle-Simpson aquifer are based primarily on outcrop areas, but the three geographic areas share similar hydrogeologic characteristics.

The geologic units that form the aquifer continue in the subsurface away from the outcrop area, but in general the water in the aquifer becomes saline where the aquifer is buried, and the Arbuckle-Simpson Hydrology Study emphasized the freshwater zone of the aquifer. The precise extent of freshwater in the Arbuckle-Simpson aquifer in the subsurface has not been determined, but freshwater is known to occur beyond the aquifer outcrop near the City of Sulphur, Oklahoma, and Chickasaw National Recreation Area (fig. 2).

\section{Geology}

The outcrop of the Arbuckle-Simpson aquifer lies in an uplifted area commonly referred to as the Arbuckle Mountains. The term "mountains" probably is misleading, because the topography consists of rolling hills to the west and an elevated plain to the east; topographic relief is on the order of hundreds of feet. The Arbuckle Mountains consist of folded and faulted igneous and metamorphic rocks of Proterozoic and Cambrian ages and Paleozoic sedimentary rocks that range in age from Cambrian through Late Pennsylvanian (fig. 3). The Arbuckle Mountains are covered on the east, north, and west by gently dipping younger strata of Pennsylvanian and Permian ages and on the south by gently southward-dipping Early Cretaceous strata of the Gulf Coastal Plain. The primary emphasis of the geology of the Arbuckle Mountains, for this study, is on the Paleozoic rocks that form the Arbuckle-Simpson aquifer.

The geology of the Arbuckle Mountains is characterized by great thicknesses of mostly carbonate sedimentary rocks, uplifts, folded structures, and large fault displacements. The history of the Arbuckle Mountains is preserved in rocks and geologic structures that span more than a billion years, from Proterozoic igneous and metamorphic rocks to Quaternary alluvial deposits. The geologic framework that resulted from the geologic events during that long time period affects groundwater flow in the present. Therefore, any assessment of the groundwater-flow system of the area must take into account the geologic history, structures, and rock types.

\section{Geologic History}

The geologic history of the Arbuckle Mountains can be characterized by four major phases of tectonics and sedimentation: (1) a rifting phase during Early and Middle Cambrian time that was marked by the development of marginal faults and igneous activity; (2) a deposition and subsidence phase during Late Cambrian through Mississippian time, when a thick sequence of shallow marine sediments accumulated along the continental margin and a thicker sequence of sediments accumulated in a subsiding sedimentary trough; (3) an uplift and deformation phase during Pennsylvanian time, which culminated in intense folding and faulting; and (4) an erosion phase, which in combination with post-Pennsylvanian tilting, resulted in southeast-trending streams and peneplanation of the Arbuckle Mountains (table 1).

The geologic history of the Arbuckle Mountains began more than one billion years ago during Proterozoic time, when the region was underlain by igneous and metamorphic rocks consisting primarily of granites and gneisses. Northwesttrending dikes in the eastern Arbuckle Mountains were emplaced around 1.3 billion years ago and are the first indication of crustal weakness that affected subsequent tectonic activity in the region (Denison, 1995).

During Early to Middle Cambrian time, the crust of the earth began to rupture in the region that is now southern Oklahoma, and a rift (or opening) formed along the zone of crustal weakness. Along the margin of the rift zone major normal faults were formed and igneous rocks were intruded (gabbros and granites) and extruded (basalts and rhyolites). The exposure of Colbert Rhyolite on the Arbuckle anticline is an indication of Cambrian volcanic activity (Ham and others, 1964; Perry, 1989).

The deposition and subsidence phase began in Late Cambrian time. As the volcanic and intrusive rocks in the rift zone cooled, the zone began to subside, resulting in a thick sedimentary trough. The trough, which today is generally referred to as the southern Oklahoma aulacogen (Johnson 


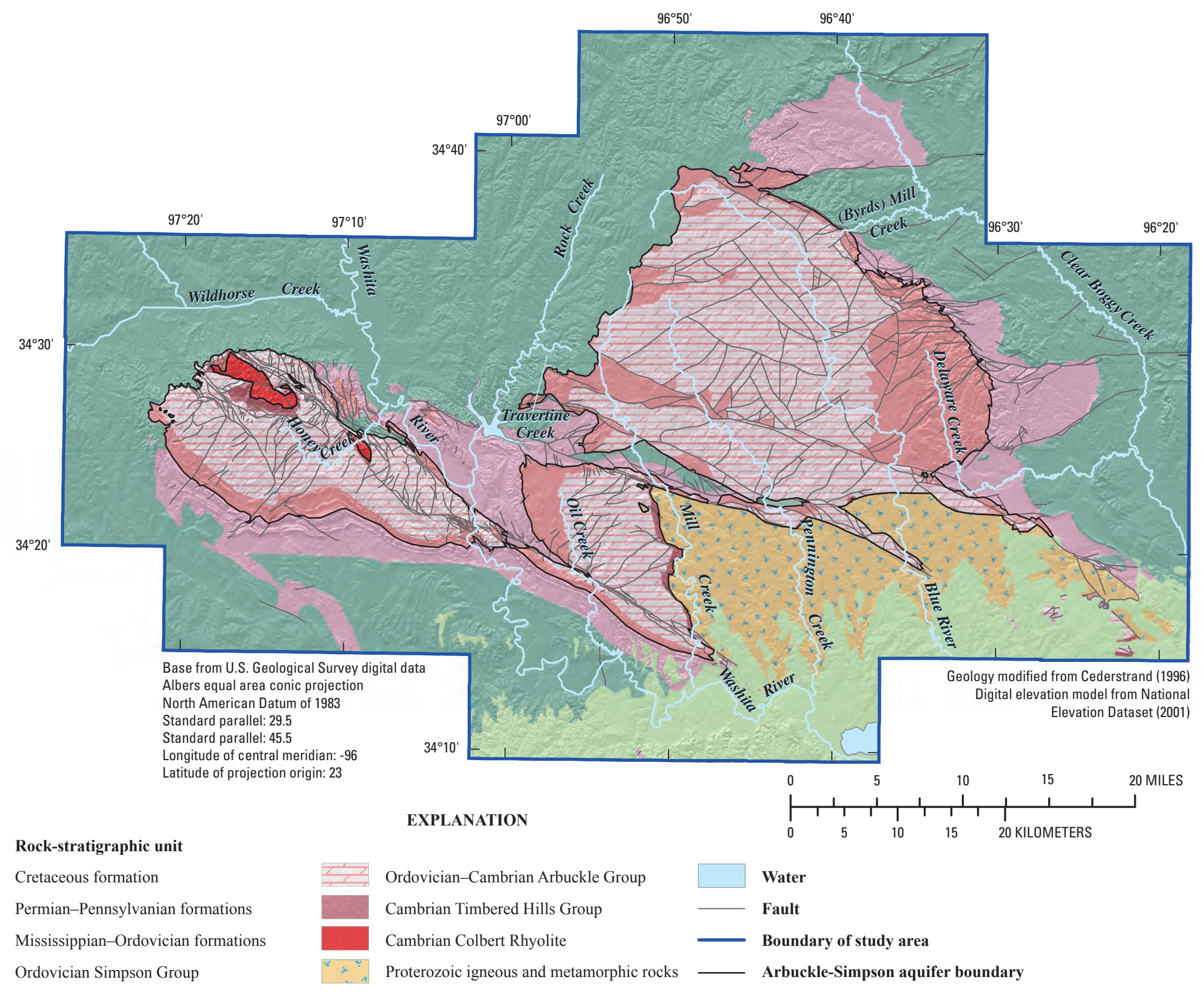

Figure 3. Geologic map of the Arbuckle-Simpson aquifer study area, south-central Oklahoma. 
Table 1. Generalized geologic history of the Arbuckle Mountains.

\begin{tabular}{|c|c|c|c|c|}
\hline Era & Period & Epoch & Tectonic events & Depositional events \\
\hline Cenozoic & Quaternary & & & $\begin{array}{l}\text { Deposition of sands, gravels, silts, and clays } \\
\text { along streams }\end{array}$ \\
\hline Mesozoic & Triassic & & & $\begin{array}{l}\text { Gap in sedimentary record because of non- } \\
\text { deposition and erosion }\end{array}$ \\
\hline \multirow[t]{9}{*}{ Paleozoic } & Permian & & & $\begin{array}{l}\text { Infilling of western basins with red shales, } \\
\text { sandstones, and evaporites }\end{array}$ \\
\hline & Pennsylvanian & Late & $\begin{array}{l}\text { Compression, overturning, and high-angle } \\
\text { thrust faulting of thick aulacogen sedi- } \\
\text { ments formed the Arbuckle anticline }\end{array}$ & $\begin{array}{l}\text { Erosion from uplifts preserved as } \\
\text { conglomerates }\end{array}$ \\
\hline & Mississippian & & \multirow{5}{*}{ Subsidence of aulacogen } & \multirow{5}{*}{$\begin{array}{l}\text { Dominantly carbonate rocks deposited on a } \\
\text { broad, shallow marine platform; thicker } \\
\text { deposits in the aulacogen }\end{array}$} \\
\hline & Devonian & & & \\
\hline & Silurian & & & \\
\hline & Ordovician & & & \\
\hline & \multirow[t]{3}{*}{ Cambrian } & Late & & \\
\hline & & Middle & \multirow{2}{*}{$\begin{array}{l}\text { Rifting and formation of the southern Okla- } \\
\text { homa aulacogen }\end{array}$} & \multirow{2}{*}{$\begin{array}{l}\text { Igneous rocks were intruded and extruded } \\
\text { along the margin of the rift zone }\end{array}$} \\
\hline & & Early & & \\
\hline Proterozoic & Neoproterozoic & & Crustal weakening & Intrusion of dikes into massive granites \\
\hline
\end{tabular}

and others, 1989), trends about $250 \mathrm{mi}$ from southeastern Oklahoma into the Texas Panhandle. More than 17,000 ft of sedimentary rocks accumulated in the aulacogen, compared to about 6,500 ft on the adjoining continental shelf (Ham, 1973).

During Late Cambrian and Early Ordovician time, shallow seas extended from what is now northern Mexico to Canada. Thick accumulations of almost pure carbonate sediments were deposited along a broad, nearly flat-lying ramp, which has been referred to as the "Great American Bank" (Lindsay and Koskelin, 1991; Wilson, 1993). Rock units formed on this ramp include the Ellenburger Group in west Texas, the Arbuckle Group in Oklahoma, the Roubidoux Formation and other geologic units that form the Ozark aquifer in the Ozark Plateau, and the Knox Group in the Appalachian Mountains. These rock units are generally dolomitized and have an average thickness of 1,000-4,000 ft. However, in the southern Oklahoma aulacogen, the Arbuckle Group is primarily limestone and is as thick as 6,700 ft (Ham, 1973; Johnson, 1991). Near the end of Early Ordovician time sea level lowered substantially, and the vast carbonate platform was exposed. The prolonged period of exposure may have provided the environment for downward flow of meteoric waters and the resulting extensive dolomitization of the carbonates on the platform. Carbonate sediments in the rapidly subsiding aulacogen were not exposed and consequently were not subjected to dolomitization (Donovan and Ross, 1991; Lynch and Al-Shaieb, 1991; and Denison, 1997).

The depositional environment changed in the Middle Ordovician when the Simpson Group, consisting of marineshelf carbonates, shales, and thick quartz sandstones, was deposited above the Arbuckle Group. Continuing through Mississippian time, the depositional environment was fairly constant with shallow-water carbonate sedimentation interrupted occasionally by terrigenous detritus and dark muds (Johnson, 1991).

The third phase of the geologic history is represented by a period of uplift and deformation. The Hunton and Tishomingo uplifts began to emerge in Early Pennsylvanian time and continued to rise through Late Pennsylvanian time. Intense mountain building along the margin of the aulacogen during Late Pennsylvanian time resulted in tight folding and high-angle thrust faulting of thick aulacogen sedimentary 
rocks. Although considerable controversy exists regarding the structural events during this phase, most geologists attribute the tectonism to a major plate collision between the North American plate and Gondwana or a smaller plate (Perry, 1989). A series of northwest-southeast-trending structures formed in southern Oklahoma, including the Arbuckle and Tishomingo anticlines, Washita Valley fault zone, and Reagan fault (fig. 4).

Remnants of several mountain-building episodes are preserved in Pennsylvanian conglomerates. The older conglomerates contain rock fragments from Hunton Group through upper Arbuckle Group formations and were derived from uplift of the Hunton anticline during Middle Pennsylvanian time. These conglomerates are preserved in the Franks graben as strata in the Desmoinesian Series and in the Mill Creek syncline as strata in the Deese Group. The younger Collings Ranch Conglomerate and conglomerate lithofacies of the Vanoss Group are products of orogeny (mountain building) during Late Pennsylvanian time. Consisting primarily of limestone clasts from the Arbuckle Group, these conglomerates were derived by erosion of the uplifted Arbuckle and Tishomingo anticlines. The younger Vanoss conglomerate, exposed in the Sulphur area, contains granite and quartz from Proterozoic granites that were exposed and eroded after the highest uplift of the Arbuckle Mountains (Ham, 1973).

The final phase in the evolution of the Arbuckle Mountains is characterized by deposition and erosion. After the intense Late Pennsylvanian orogeny, Pennsylvanian detritus buried the Arbuckle Mountains, and red beds and evaporites filled basins to the west during the subsequent Permian time (Johnson and others, 1989). Shallow Cretaceous seas deposited sands and carbonates over the region and further eroded the Arbuckle Mountains. The nearly flat top of the Arbuckle Mountains is the result of peneplanation during the Cretaceous Period (Donovan, 1991). Uplift of the Rocky Mountains in Late Cretaceous and Early Tertiary time led to tilting and erosion, which established dominant southeastflowing river systems. During the recent Quaternary Period, alluvial and terrace sediments were deposited along the streams and rivers (Johnson and others, 1989).

Elements of two tectonic settings are exposed in the Arbuckle Mountains: aulacogen and shelf. These settings had a profound effect on the type of basement rock and the stratigraphic thickness, lithology, diagenesis (postburial alteration), and degree of structural deformation in the Arbuckle-Simpson aquifer. Rocks northeast of the Washita Valley fault zone represent deposition on the stable continental shelf and are in the central and eastern Arbuckle-Simpson aquifer. Basement rocks on the shelf consist dominantly of massive Proterozoic granite. Paleozoic rocks formed on this stable basement are generally thinner than in the aulacogen. Arbuckle Group carbonates on the shelf were subjected to prolonged periods of exposure that resulted in extensive dolomitization. Structures developed on the shelf are characterized by moderate folding and block faulting.
Rocks southwest of the Washita Valley fault zone represent deposition in the southern Oklahoma aulacogen and are in the western Arbuckle-Simpson aquifer. The basement rocks in the aulacogen consist mainly of flows of basalt and rhyolite and thin sills of granite that filled the aulacogen during initial development in Cambrian time. A thick sequence of Paleozoic sediments was deposited above the Cambrian rhyolites as the weakened basin subsided. Arbuckle Group carbonates in the rapidly subsiding aulacogen were not subjected to prolonged exposure during times of low sea levels and were not dolomitized as extensively as the carbonates on the shelf. Pennsylvanian mountain building along the margin of the aulacogen caused tight folding, local overturning, and intense faulting of the western Arbuckle-Simpson aquifer. Therefore, strata in the central and eastern Arbuckle-Simpson aquifer consist of thinner carbonate sequences than strata in the western Arbuckle-Simpson aquifer. The carbonates in the central and eastern Arbuckle-Simpson aquifer are dominated by dolostone, whereas the carbonates in the western ArbuckleSimpson aquifer are dominated by limestone. In addition, structural deformation in the central and eastern ArbuckleSimpson aquifer is less pronounced than in the western Arbuckle-Simpson aquifer.

\section{Hydrostratigraphy}

The Arbuckle-Simpson aquifer is contained in three major rock units of Late Cambrian to Middle Ordovician age: the Timbered Hills, Arbuckle, and Simpson Groups. The aquifer is underlain by low permeability basement rocks, consisting of Cambrian rhyolites and Proterozoic granites and gneisses. In areas where the top of the aquifer dips below the surface, the aquifer is confined above by younger rocks of various ages. All geologic units younger than the Simpson Group are combined into a single unit termed "postSimpson, undifferentiated" for this study. The geologic units for this study also were grouped into four hydrostratigraphic units [bodies of rock with considerable lateral extent that act as a reasonably distinct hydrologic system (Maxey, 1964)]: basement, Arbuckle-Timbered Hills, Simpson, and post-Simpson. The time-stratigraphic, rock-stratigraphic, hydrostratigraphic, and hydrogeologic units associated with the aquifer are listed in table 2 and are discussed in the following section, from oldest to youngest.

\section{Basement Hydrostratigraphic Unit}

The oldest rocks in the Arbuckle Mountains are Mesoproterozoic igneous and metamorphic rocks, consisting of the Tishomingo Granite, Troy Granite, and unnamed granodiorite and granitic gneiss. Dated at 1,350 to 1,400 million years old, these granitic rocks are at land surface in the core of the Tishomingo and Belton anticlines (fig. 3 and fig. 4) and as a few small inliers in the Tishomingo anticline (Ham and others, 1964; Denison, 1973). The granitic rocks are cut by a variety of Proterozoic and Cambrian dikes that have a 


\section{Fault or fault zone}

$\checkmark$ Thrust fault-Sawteeth on upper plate

$\longleftarrow$ Syncline—Arrow shows direction of plunge

$\longleftarrow$ Overturned syncline—Arrow shows direction of plunge

$\longleftarrow$ …... Anticline-Arrow shows direction of plunge;

$\longleftarrow$ Overturned anticline-Arrow shows direction of plunge

$\stackrel{f}{\checkmark} \quad$ Anticline-No primary direction of plunge

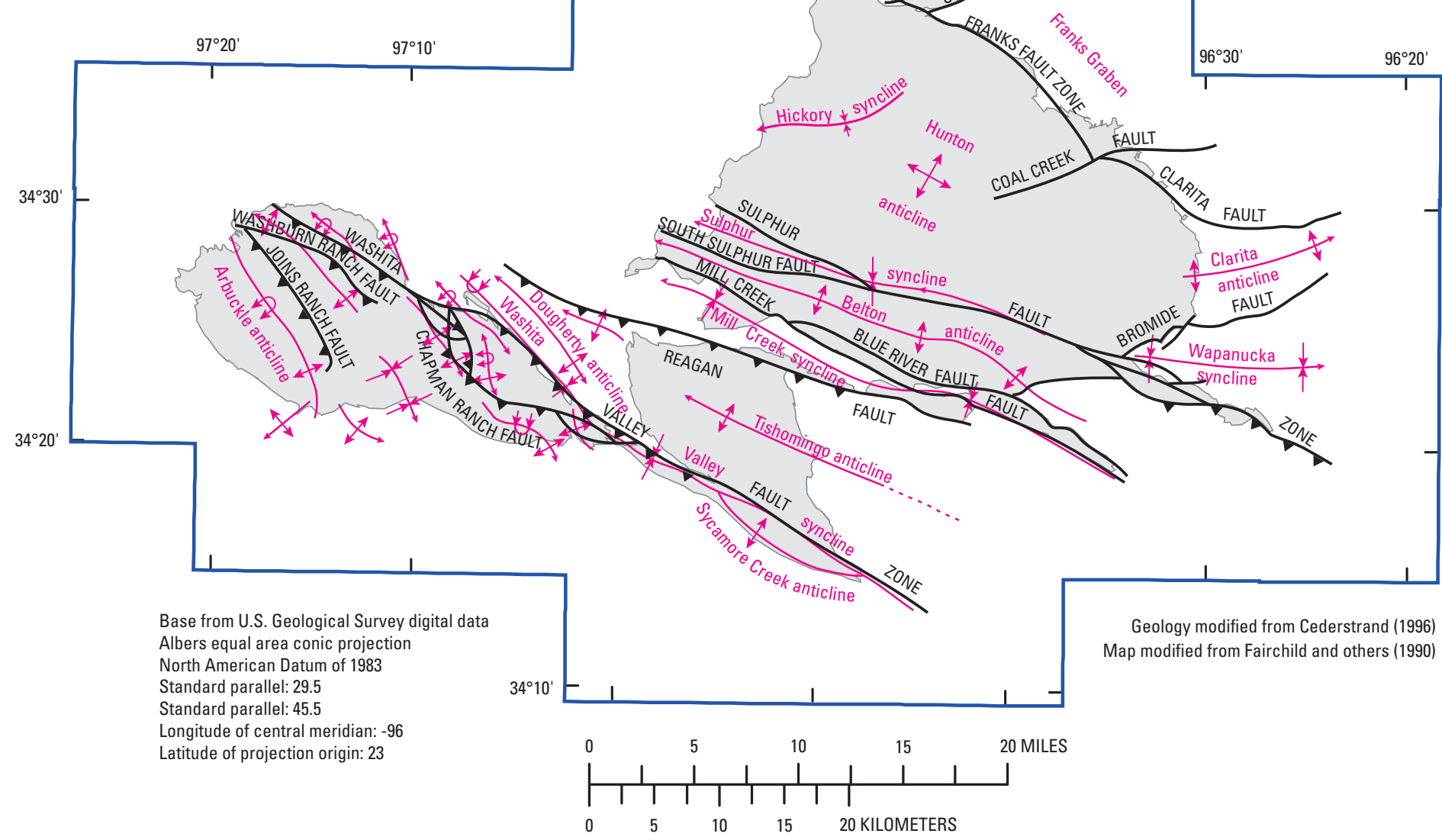

Figure 4. Primary structural features of the Arbuckle-Simpson aquifer, south-central Oklahoma. 
Table 2. Comparison of time-stratigraphic, rock-stratigraphic, hydrostratigraphic, and hydrogeologic units in the Arbuckle-Simpson aquifer, south-central Oklahoma.

\begin{tabular}{|c|c|c|c|c|}
\hline Time-stratigraphic unit & \multicolumn{2}{|c|}{ Rock-stratigraphic unit } & Hydrostratigraphic unit & Hydrogeologic unit \\
\hline Quaternary & \multirow{5}{*}{$\begin{array}{l}\text { Post-Simpson Geologic Units, } \\
\text { Undifferentiated }\end{array}$} & Alluvium & \multirow{5}{*}{ Post-Simpson } & \multirow{5}{*}{ Upper Confining Unit } \\
\hline Permian & & Stratford Formation & & \\
\hline Pennsylvanian & & $\begin{array}{l}\text { Vanoss Group } \\
\text { Ada Formation (Collings Ranch } \\
\text { Conglomerate) } \\
\text { Deese Group (Desmoinesian } \\
\text { Series) } \\
\text { Atoka Formation } \\
\text { Wapanucka Limestone } \\
\text { Springer Formation }\end{array}$ & & \\
\hline Mississippian & & $\begin{array}{l}\text { Caney Shale } \\
\text { Sycamore Limestone }\end{array}$ & & \\
\hline Devonian & & Woodford Shale & & \\
\hline Early Ordovician & \multirow[b]{2}{*}{ Arbuckle Group } & West Spring Creek Formation & \multirow{3}{*}{ Arbuckle-Timbered Hills } & \multirow{3}{*}{ Arbuckle-Simpson Aquifer } \\
\hline \multirow[t]{2}{*}{ Late Cambrian } & & $\begin{array}{l}\text { Kindblade Formation } \\
\text { Cool Creek Formation } \\
\text { McKenzie Hill Formation } \\
\text { Butterly Dolomite } \\
\text { Signal Mountain Formation } \\
\text { Royer Dolomite } \\
\text { Fort Sill Limestone }\end{array}$ & & \\
\hline & Timbered Hills Group & $\begin{array}{l}\text { Honey Creek Limestone } \\
\text { Reagan Sandstone }\end{array}$ & & \\
\hline
\end{tabular}


northwest strike (Denison, 1973; Denison, 1995). The massive granitic rocks extend northward in the subsurface as the basement rock of the eastern Arbuckle-Simpson aquifer and range from 3,100 to 4,600 ft below land surface (Campbell and Weber, 2006).

Whereas the central and eastern parts of the ArbuckleSimpson aquifer are underlain by massive Proterozoic granitic rocks, the western Arbuckle-Simpson aquifer is underlain by Cambrian rhyolites of volcanic origin. The 525-million-yearold Colbert Rhyolite is exposed on the crest of the Arbuckle anticline, and is as much as $4,500 \mathrm{ft}$ thick in the subsurface (Denison, 1973; Denison 1995).

The crystalline structure of the igneous and metamorphic rocks is thought to have very low hydraulic conductivity. No high-yield water wells are completed in the igneous and metamorphic rocks near the aquifer.

\section{Arbuckle-Timbered Hills Hydrostratigraphic Unit}

The Late Cambrian-age Timbered Hills Group, consisting of the Reagan Sandstone and the Honey Creek Formation, overlies the irregular surface of eroded igneous and metamorphic rocks and is exposed only in small areas (the outcrop of the Timbered Hills Group is about $8 \mathrm{mi}^{2}$ of the $520-\mathrm{mi}^{2}$ area of the total aquifer outcrop) in the ArbuckleSimpson aquifer (fig. 3). The basal Reagan Sandstone is an arkosic and glauconitic sandstone consisting of reworked detritus weathered from the basement rocks. The sandstone thickens in paleotopographic lows and thins over highs on the basement surface. The Reagan Sandstone generally is 50-200 $\mathrm{ft}$ thick, but is as much as $450 \mathrm{ft}$ thick in the western ArbuckleSimpson aquifer. The overlying Honey Creek Formation is a 100- to 200-ft-thick fossiliferous limestone in the western Arbuckle-Simpson aquifer that grades into a sequence of sandy dolostones in the eastern Arbuckle-Simpson aquifer (Johnson, 1991).

The combined Arbuckle and Timbered Hills Groups in western Oklahoma are designated a major aquifer (the Arbuckle-Timbered Hills aquifer) by the Oklahoma Water Resources Board (Oklahoma Water Resources Board, 2010), but little is known about the water-bearing properties of the Timbered Hills Group in the Arbuckle Mountains. No identifiable confining layer separates the Timbered Hills Group from the Arbuckle Group in the Arbuckle Mountains, and therefore, the Timbered Hills Group is considered to be part of the Arbuckle-Simpson aquifer. For this study, the Arbuckle and Timbered Hills Groups are designated as the Arbuckle-Timbered Hills hydrostratigraphic unit (table 2).

The Arbuckle Group of Late Cambrian to Early Ordovician age overlies the Timbered Hills Group. The Arbuckle Group consists of a thick sequence of carbonate rocks that is as much as $6,700 \mathrm{ft}$ of limestone in the western Arbuckle-Simpson aquifer, but which thins to an estimated $4,000 \mathrm{ft}$ of mostly dolostone in the central Arbuckle-Simpson aquifer (Ham, 1973; Johnson, 1991). The Arbuckle Group further thins to about 3,000 ft in the eastern Arbuckle-Simpson aquifer, based on few borehole-geophysical and drill-hole data. The entire Arbuckle Group has been removed by erosion over parts of the Belton, Tishomingo, and Arbuckle anticlines.

The Arbuckle Group has been divided into six primary formations based on a combination of lithostratigraphy and biostratigraphy. These formations are, from oldest to youngest, the Fort Sill Limestone and the Signal Mountain, McKenzie Hill, Cool Creek, Kindblade, and West Spring Creek Formations. In addition, two thick dolostones, the Royer and Butterly, are formally recognized in the Arbuckle Mountains (Denison, 1989; Ham and others, 1990; Ragland and Donovan, 1991). The Royer Dolomite is a facies equivalent of limestone in the upper part of the Fort Sill Limestone and lower part of the Signal Mountain Formation, and the Butterly Dolomite is a facies equivalent in the upper Signal Mountain and lower McKenzie Hill Formations. The Butterly Dolomite rests directly on the Royer Dolomite in the central ArbuckleSimpson aquifer (Ham, 1950).

A well drilled for oil exploration on the Lawrence uplift, at about N34.657 latitude, W96.728 longitude (NAD 83) (shown as Type Log on figure 2), penetrated the entire Arbuckle Group. The gamma-ray log of this well is used in this study as the type log for the Arbuckle Group in the eastern Arbuckle-Simpson aquifer (fig. 5). Formation contacts were selected on the basis of lithologic characteristics of rock cuttings, microfossil (ostracode) biostratigraphy interpreted from thin sections, and correlation of the gamma-ray log with other well logs in the study area. The total thickness of the Arbuckle Group in the well is $3,100 \mathrm{ft}$.

The Arbuckle sediments were deposited in a shallowwater subtidal and peritidal environment (Donovan, 1991). Primary lithofacies include micrite, peloidal facies, oolitic facies, fossiliferous facies, algal boundstones, intraformational conglomerates, and intraformational breccias. Quartz detritus is a major component in the three upper formations of the Arbuckle Group. Two bedded chert facies have been recognized, one each in the Cool Creek and Kindblade Formations. Only traces and pseudomorphs of evaporite minerals are preserved in the surface exposures of the Arbuckle Group (Ragland and Donovan, 1991).

Limestone is the dominant carbonate in the western Arbuckle-Simpson aquifer, but a transition to dolostone exists in the central and eastern Arbuckle-Simpson aquifer (Ham, 1950). The lateral transition from limestone to dolostone happens near the boundary of the southern Oklahoma aulacogen, with the dolostone probably resulting from exposure of the carbonates to meteoric waters (Donovan and Ross, 1991; Johnson, 1991; Lynch and Al-Shaieb, 1991; and Denison, 1997).

Several unconformities in the Arbuckle Group indicate the carbonates were exposed to weathering numerous times, allowing karst development. Paleokarst features, such as dissolution in cavities, collapse breccias, fractures enlarged by dissolution, and locally extensive vuggy porosity, have been recognized in surface exposures and cores in the Arbuckle Group. The fracturing and brecciation interconnect much of 

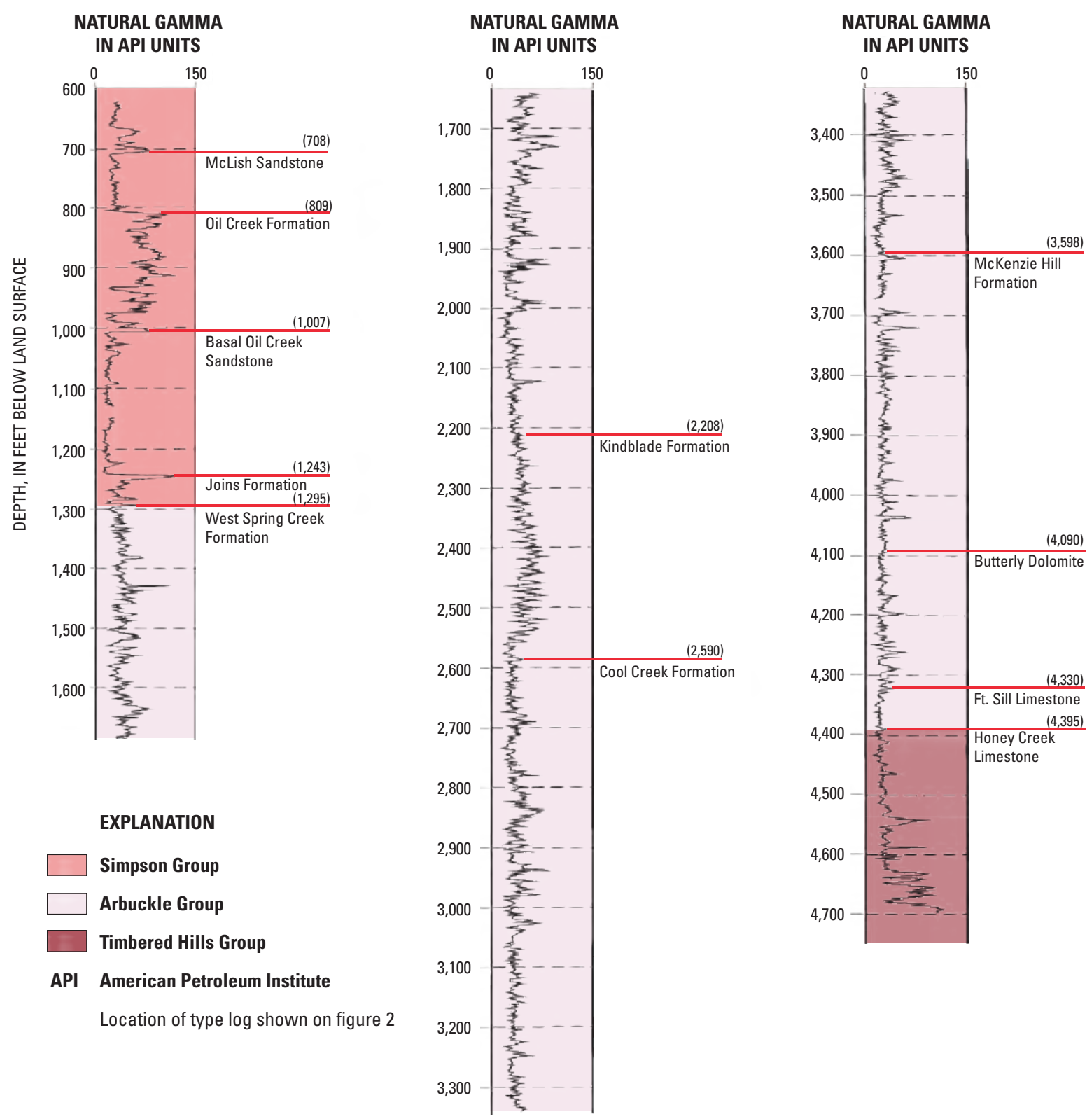

Figure 5. Type log of the Arbuckle Group in the eastern Arbuckle-Simpson aquifer, south-central Oklahoma.

the dissolution porosity, producing enhanced permeability (Lynch and Al-Shaieb, 1991; Donovan, 1991). A test well drilled as part of this study (shown as Test Well on fig. 2) contains voids with red-clay and calcite fillings, which are indicative of carbonate dissolution and karst features at depth.

The Arbuckle Group constitutes the major part of the Arbuckle-Simpson aquifer in terms of thickness, outcrop extent, and volume of groundwater. Water is obtained from cavities, solution channels, fractures, and intercrystalline porosity in the limestone and dolostone. Wells completed in the Arbuckle Group commonly yield 200 to 500 gallons per minute (gal/min). Some deeper wells $(800-1,000 \mathrm{ft})$ are reported to yield as much as $2,500 \mathrm{gal} / \mathrm{min}$, whereas shallow wells may yield only minor amounts of water (Fairchild and others, 1990).

\section{Simpson Hydrostratigraphic Unit}

The Simpson Group of Middle Ordovician age is the youngest geologic unit of the aquifer. The Simpson Group is as much as $2,300 \mathrm{ft}$ thick in the western Arbuckle-Simpson aquifer, but generally is less than 1,000 $\mathrm{ft}$ thick in the eastern Arbuckle-Simpson aquifer. Geologic units of the Simpson Group are exposed over about $145 \mathrm{mi}^{2}$ of the aquifer outcrop, which is about one third of the total outcrop area. Rocks of 
the Simpson Group are preserved along the flanks of major anticlines and in structurally low areas, but are absent because of erosion over the structurally higher parts (Ham, 1973). The most prominent outcrop of Simpson Group rocks is on the eastern part of the Hunton anticline. Other areas where the Simpson Group is exposed include the Sulphur syncline, the southern and western parts of the central Arbuckle-Simpson aquifer, and the southern and northern parts of the western Arbuckle-Simpson aquifer (figs. 2, 3, and 4).

The Simpson Group is characterized by porous quartzose sandstones interbedded with marine limestones and dolostones, and greenish-gray shales. The sandstones consist of poorly cemented, very fine- to fine-grained, well-sorted, rounded quartz grains (Ham, 1973; Johnson, 1991; Denison, 1997). Deposition of the Simpson Group began after sea level was lowered and windblown sand covered the emergent carbonate shelf. As sea level rose again, the sand was reworked into sheetlike deposits, which were subsequently overlain by marine shales and limestones. Successive fluctuations of sea level during Early to Late Ordovician time resulted in deposition of a series of sandstones, shales, and limestones (McPherson and others, 1988; Johnson, 1991).

The Simpson Group consists of five formations: the Joins, Oil Creek, McLish, Tulip Creek, and Bromide Formations. The Oil Creek, McLish, and Bromide Formations are distributed throughout the Arbuckle Mountains. The Joins and Tulip Creek Formations, however, are thickest in the western Arbuckle-Simpson aquifer and are either very thin or absent in the central and eastern Arbuckle-Simpson aquifer. The Joins Formation consists of thin limestones and shales with a thin basal conglomerate. Each of the four upper formations consists of a basal sandstone overlain by a sequence of shale and limestone. In the eastern Arbuckle-Simpson aquifer the basal Oil Creek and McLish sandstones are well developed, with thicknesses as much as 400 and $165 \mathrm{ft}$, respectively (Ham, 1945; Denison, 1997). These uncemented quartz sandstones are locally mined for the manufacture of glass. Water in the Simpson Group is stored primarily in pore spaces between the sand grains in the sandstones. Wells completed in the Simpson Group commonly yield from 100 to $200 \mathrm{gal} / \mathrm{min}$ (Fairchild and others, 1990).

\section{Post-Simpson Hydrostratigraphic Unit}

Rock units younger than the Simpson Group overlie the Arbuckle-Simpson aquifer beyond the aquifer outcrop. These post-Simpson geologic units include Paleozoic rocks of Late Ordovician to Permian age, Mesozoic rocks of Early Cretaceous age, and Cenozoic rocks of Quaternary age. Geologic units of Late Ordovician to Mississippian age are exposed along the margins of the Arbuckle-Simpson aquifer. These units include the Viola Group (Ordovician), Sylvan Shale (Ordovician), Hunton Group (Ordovician-Devonian), Woodford Shale (Devonian-Mississippian), and Sycamore Limestone and Caney Shale (Mississippian).
Rocks of Middle to Late Pennsylvanian age are exposed around most of the Arbuckle Mountains. Of primary interest to this study is the Vanoss Group, which confines the Arbuckle-Simpson aquifer near Sulphur and Chickasaw National Recreation Area (CNRA). The Vanoss Group lies unconformably over the Arbuckle and Simpson Groups on the western flank of the Hunton anticline, where the dominant lithology is conglomerate with some sandstone, shale, and minor nodular limestone. Derived from erosional remnants from the Arbuckle and Tishomingo anticlines, the conglomerate lithofacies of the Vanoss Group has a maximum thickness of $650 \mathrm{ft}$ (Ham, 1973). The Vanoss conglomerate is composed of well-rounded to subangular limestone and dolostone pebbles, cobbles, and boulders, with smaller amounts of sandstone, siltstone, chert, granite, and gneiss. Rocks of the Vanoss Group are cemented in varying degrees, with calcite as the most common cement (Donovan and Butaud, 1993).

Early Cretaceous rock units consisting of sandstone, limestone, and shale lie unconformably on older units of various ages in the southern part of the study area. These units do not overlie the Arbuckle-Simpson aquifer except along the extreme southeastern edges of the aquifer.

The youngest geologic unit in the study area is Quaternary alluvium, consisting of unconsolidated gravel, sand, silt, and clay. Minor alluvial deposits lie along the Washita River and larger streams in the study area (Hart, 1974). Where the alluvial deposits overlie the ArbuckleSimpson aquifer, these deposits are very thin and poorly defined and, therefore, are not considered as a separate hydrostratigraphic unit in the study area.

\section{Structural Geology}

The Arbuckle-Simpson aquifer consists of a series of northwest-southeast-trending structural features that are separated from each other by major Paleozoic faults and fault zones (fig. 4). Structural deformation is greatest in the western Arbuckle-Simpson aquifer, where vertical and overturned beds are evident. Structural deformation is less pronounced in the central and eastern Arbuckle-Simpson aquifer, where the rocks are more flat lying (dips less than 20 degrees), and are deformed mainly by block faulting. The major structural features are described in this section, from northeast to southwest.

The eastern Arbuckle-Simpson aquifer is dominated by the Hunton anticline, but also includes other structural features, including the Belton and Clarita anticlines, the Sulphur syncline, and the Lawrence uplift. The structural configuration of the eastern Arbuckle-Simpson aquifer is shown in a structural contour map for the top of the Arbuckle Group on figure 6 and in a series of cross sections on figure 7.

The Hunton anticline is a broad anticlinal fold that is bounded on the north by the Lawrence uplift (fig. 4), on the northeast and east by the Franks fault zone and Clarita fault, and on the south by the Sulphur fault zone. The 


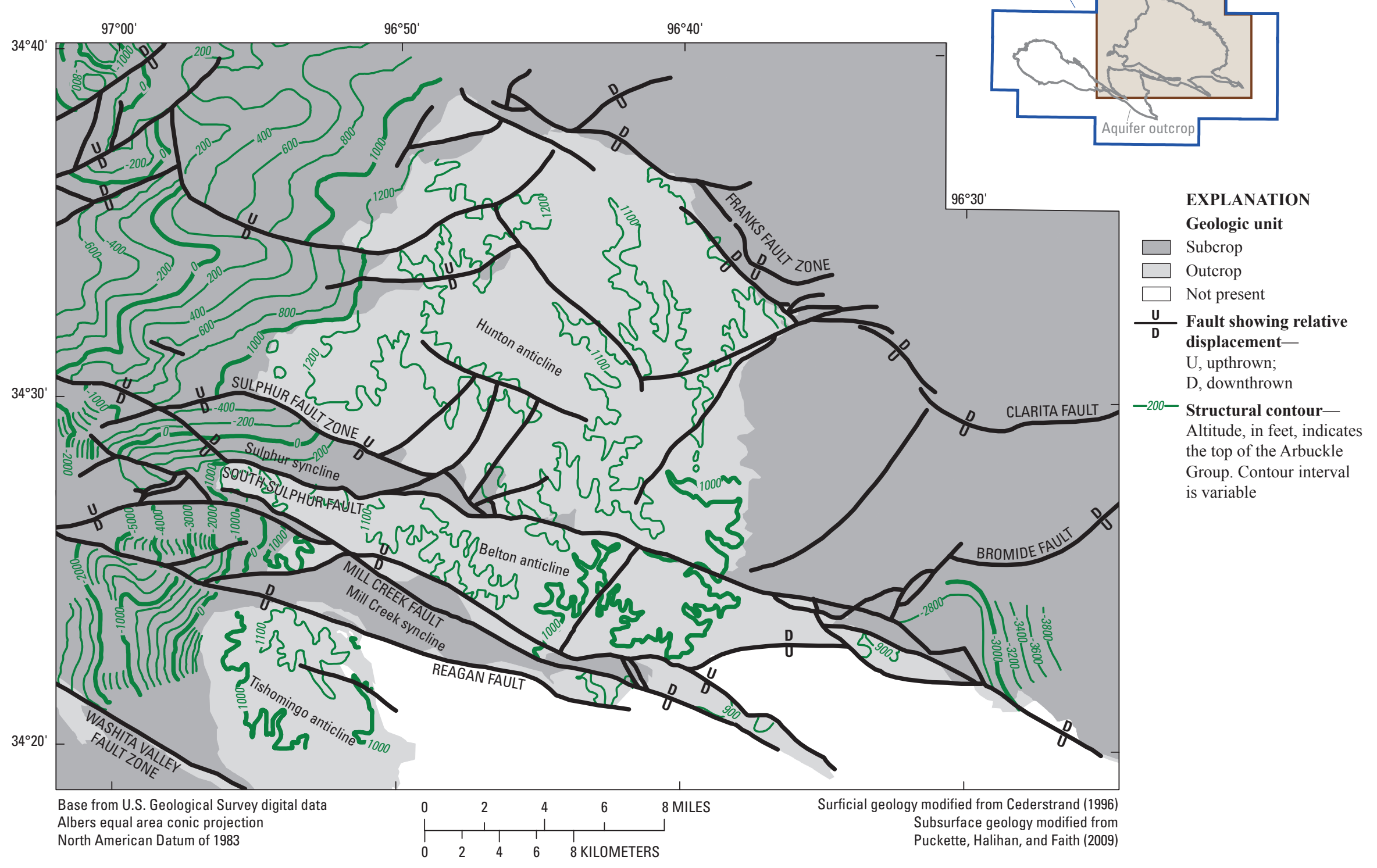




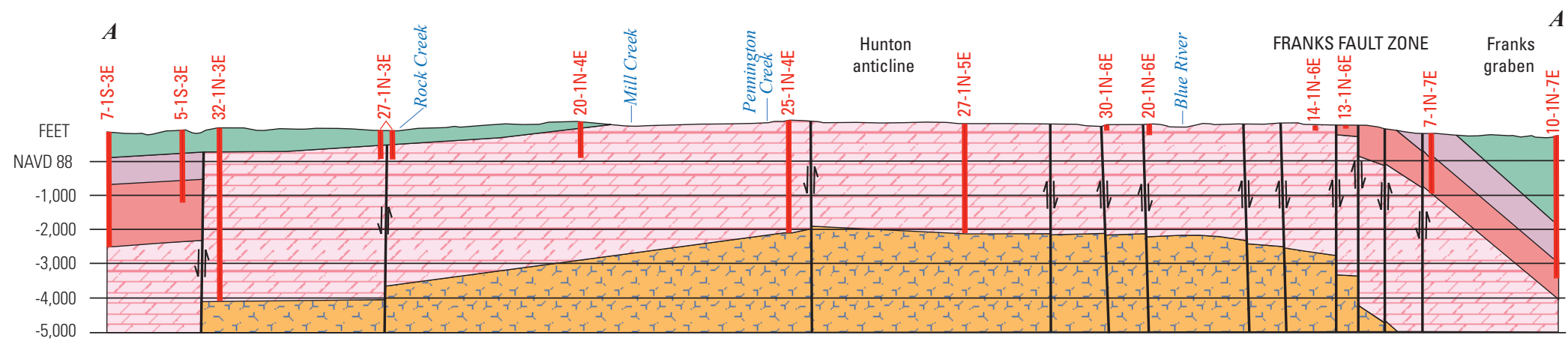

VERTICAL EXAGGERATION x5

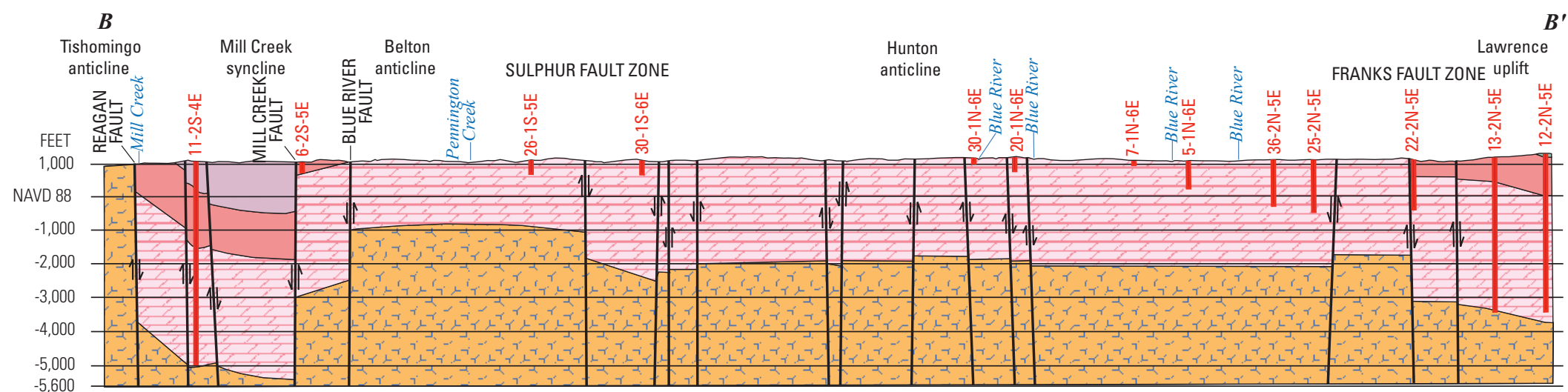

VERTICAL EXAGGERATION x3.57

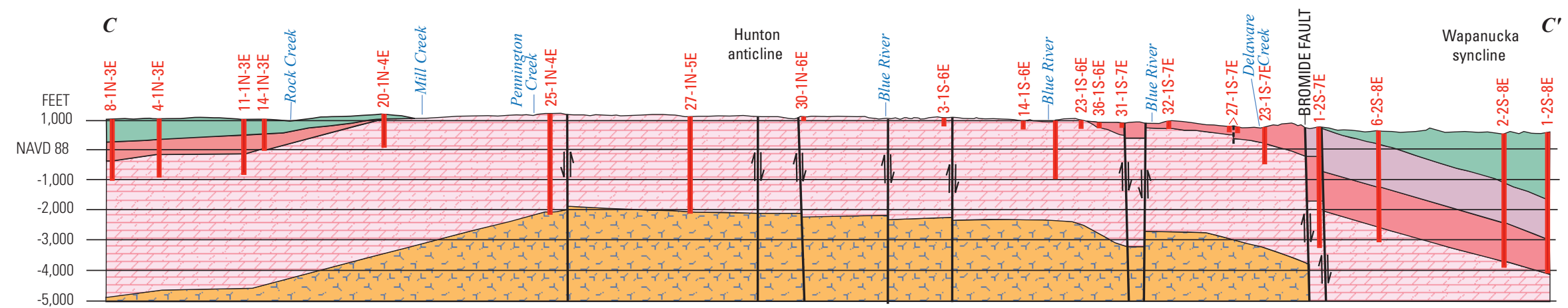

VERTICAL EXAGgERATION x4.28

NAVD 88, NORTH AMERICAN VERTICAL DATUM OF 1988

Figure 7. Generalized cross sections across the eastern Arbuckle-Simpson aquifer, south-central Oklahoma. 


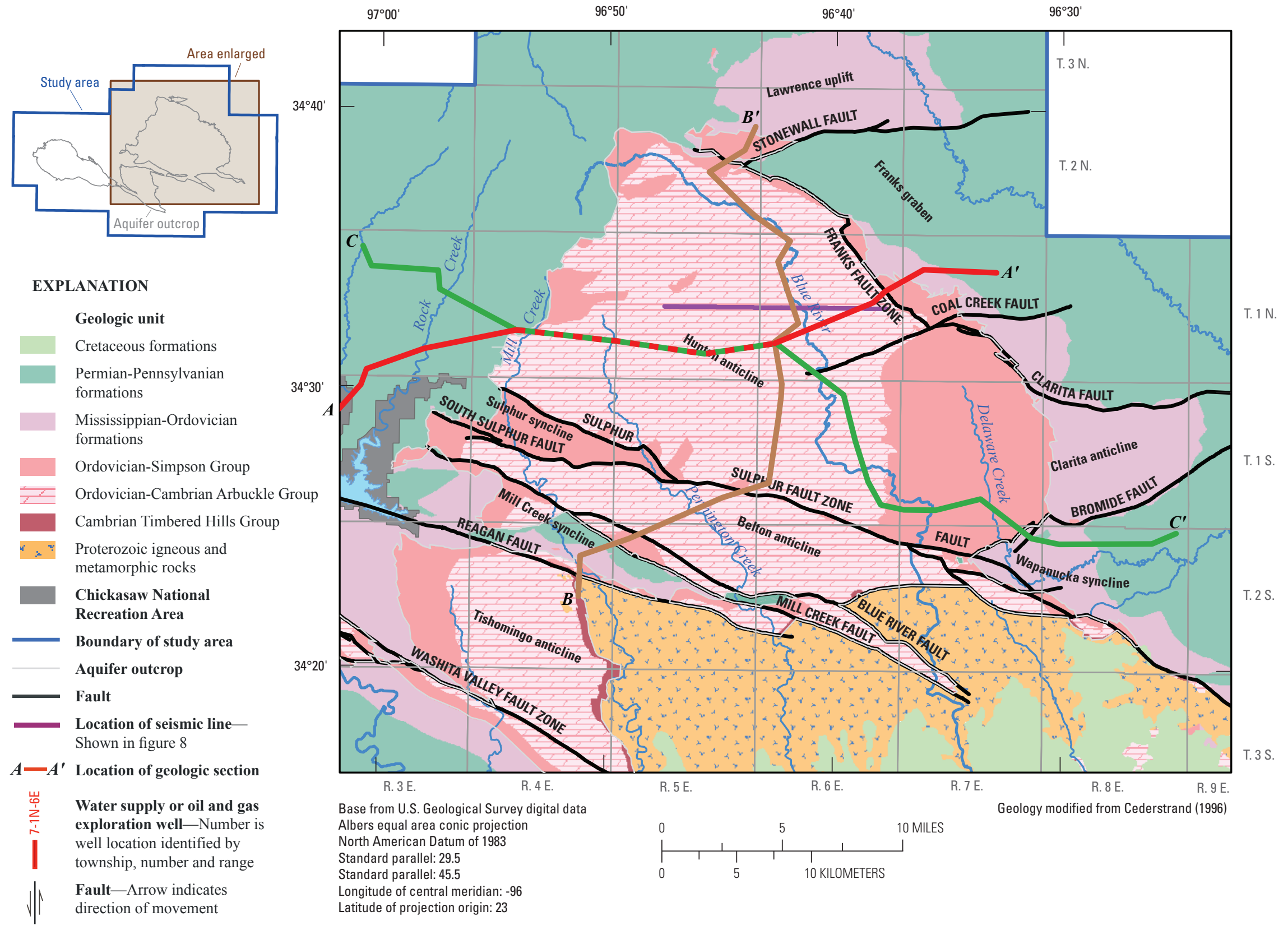

Figure 7. Generalized cross sections across the eastern Arbuckle-Simpson aquifer, south-central Oklahoma.-Continued 
Franks fault zone consists of a series of high-angle, downto-the-northeast faults (fig. 6). The southeastern boundary of the Hunton anticline is influenced by the Bromide fault and Wapanucka syncline, but is less faulted than the area bordered by the Franks fault zone (sections A and $\mathrm{C}$ in fig. 7). The northwestern and southeastern flanks of the Hunton anticline dip gently westward and eastward, respectively. Arbuckle Group carbonates of the West Spring Creek and Kindblade Formations are exposed in the central part of the Hunton anticline (Ham and others, 1990). As illustrated in sections A and C in figure 7, Arbuckle and Simpson strata dip gently beneath Permian-Pennsylvanian formations on the northwestern and western flanks, and dip beneath progressively younger strata on the southeastern flank.

South of the Hunton anticline is the Belton anticline, which is a northwest-plunging folded fault block. The Belton anticline is bounded on the north by the Sulphur fault zone and on the south by the Mill Creek fault (section $B$ in fig. 7). A large fault southeast of the Belton anticline juxtaposes Proterozoic granite against rocks of the Arbuckle and Timbered Hills Groups. The Belton anticline is structurally higher than the Hunton anticline, and as a result, the upper Arbuckle formations have been eroded on structurally high areas to expose the lower Cool Creek and McKenzie Hill Formations.

The Sulphur syncline is wedged between the Belton and Hunton anticlines and is bounded by the Sulphur fault zone on the north and by the South Sulphur fault on the south. Preserved in the syncline are rock formations of the Simpson Group. The Sulphur syncline terminates in outcrop east of CNRA (fig. 7), where the surface expression is masked by the overlying Vanoss Group. The Simpson Group is absent in the northern part of CNRA, where the Vanoss Group unconformably overlies the Arbuckle Group (section A in fig. 7). Analysis of geophysical gravity data indicates that the South Sulphur fault extends through CNRA, but the Sulphur fault zone appears to deviate to the south of CNRA, and terminates against the South Sulphur fault. Therefore, the Sulphur syncline does not appear to extend beneath CNRA, and may in fact be a graben rather than a syncline (Cates, 1989; Scheirer and Hosford Scheirer, 2006).

The Mill Creek syncline is south of the Belton anticline and is bounded by the Mill Creek and Reagan faults. The Mill Creek syncline is a narrow, northwest-trending graben consisting of more than $8,000 \mathrm{ft}$ of tightly folded Paleozoic strata. Stratigraphic displacement of the Mill Creek fault is estimated to be about 5,000 ft where Arbuckle strata on the Belton anticline are in contact with Pennsylvanian-age Deese conglomerate in the Mill Creek syncline (Ham, 1945).

The Tishomingo anticline is a broad, northwest-plunging, folded fault block. Proterozoic igneous and metamorphic rocks are exposed to the east, and progressively younger rocks are exposed to the west. To the southeast, the anticline is covered unconformably by nearly horizontal Cretaceous sandstones. The Tishomingo anticline is sharply delimited on the north by the Reagan fault and on the south by the Washita Valley fault zone. The fault block has stratigraphic displacement of at least 7,500 ft near Mill Creek, where Proterozoic granites are in contact with Middle Ordovician Simpson strata in the Mill Creek syncline (Ham, 1949). South of the Washita Valley fault zone is the Sycamore Creek anticline, a narrow, asymmetrical fold with steep dips on the south (Ham, 1950).

The Arbuckle anticline is a structurally complex asymmetric fold that is overturned to the northeast. The north side consists of three smaller anticlinal folds, all of which have upright, moderately to steeply dipping beds. The greatest structural relief of the Arbuckle Mountains is near the western edge of the Arbuckle anticline, on which about $5 \mathrm{mi}^{2}$ of the Colbert Rhyolite are exposed. The rocks of the western Arbuckle-Simpson aquifer are intricately cut by large and small faults. Major faults include the Joins Ranch, Chapman Ranch, Washburn Ranch, and Washita Valley faults (Ham, 1950).

The major northwest-southeast-trending faults first became active at the time the basement rocks formed, and were reactivated repeatedly during Paleozoic time (Harlton, 1966; Denison, 1995). The largest (by linear extent and displacement) of these major faults are the Washita Valley fault zone, Reagan fault, Mill Creek fault, and Sulphur fault zone. Of these faults, the Washita Valley fault zone is the most prominent. The surface trace of this west-northwest-striking fault zone extends $35 \mathrm{mi}$ through the Arbuckle Mountains, where the fault zone separates the Arbuckle and Tishomingo anticlines. The Washita Valley fault zone is thought to have formed during the initial rifting as high-angle normal faults. Forming the northern boundary of the southern Oklahoma aulacogen, the fault zone divides thick aulacogen facies from thinner shelf facies (Ham and others, 1964; Sutherland, 1989).

Most of the major northwest-southeast-trending faults are high angled and are considered to be the result of leftlateral wrench (strike-slip), transform, and thrust deformation. Analysis of gravity data collected near CNRA indicates that the Mill Creek fault is near vertical. The South Sulphur fault appears to be north dipping, which is consistent with normal fault displacement at the southern edge of the Sulphur syncline. The Reagan fault appears to be south dipping, which is consistent with the Reagan fault being mapped as a thrust fault (Scheirer and Hosford Scheirer, 2006).

Numerous smaller faults throughout the region terminate against the major northwest-oriented faults and each other. These smaller faults are characterized by short lengths, small offsets of stratigraphic units, and a range of orientations (Scheirer and Hosford Scheirer, 2006).

Information obtained from surface mapping and subsurface geophysical data indicate the eastern ArbuckleSimpson aquifer is highly faulted. Several prominent faults have been mapped at the surface, as seen on the geologic map (fig. 3), but many more have been identified through geophysical methods, including seismic, electric resistivity imaging, ground-penetrating radar, and helicopter electromagnetic surveys (Halihan and others, 2009b; Kennedy, 2008; Riley, 2004; Sample, 2008; Scheirer and 
Hosford Scheirer, 2006; Smith and others, 2009; Young and others, 2009). The deeper part of the eastern ArbuckleSimpson aquifer, from 900 to 3,500 ft below land surface, was studied through a preexisting seismic survey (Kennedy, 2008). Numerous faults are observed in the deeper part of the Arbuckle-Simpson aquifer along the seismic-reflection line, with a fault density of about 2.53 faults per mile (fig. 8). Several of these steeply dipping faults penetrate the granitic basement, which is estimated at a depth of 3,500 $\mathrm{ft}$ along the seismic line. Also observed along the line is a fault-bounded graben at the aquifer/basement boundary.

\section{Three-Dimensional Geologic Framework Modeling}

A digital, three-dimensional geologic framework model was constructed, using Dynamic Graphic's EarthVision ${ }^{\mathrm{TM}}$ software, to define the geometric relations of the eastern Arbuckle-Simpson aquifer (Faith and others, 2010). The subsurface geologic framework of the eastern ArbuckleSimpson aquifer, and overlying and underlying geologic units, was poorly defined prior to this study because of the complex geology of the aquifer and lack of well control (stratigraphic data) points. The framework model helped to define the inner geometries of fault blocks and subsurface stratigraphicjuxtaposition of rock units across the complex fault zones. The model contains 54 faults and four hydrostratigraphic units: basement, Arbuckle-Timbered Hills, Simpson, and postSimpson (table 2).

\section{Geologic Data and Interpretation Methods}

Construction of the geologic framework model involved integrating outcrop geology from existing maps and reports, available subsurface geophysical surveys, drill-hole reports and geophysical logs, and surface information compiled from several geologic and hydrogeologic reports. The framework model defined the volumetric extent of the post-Simpson, Simpson, and Arbuckle-Timbered Hills hydrostratigraphic units and top of the basement hydrostratigraphic unit. A 10-meter (m) by 10- $\mathrm{m}^{4}$ USGS Digital Elevation Model (DEM) was used to define the land-surface topography and provide elevation data along stratigraphic contacts extracted from Cederstrand's (1996) digital geologic map of the area.

Geologic data for the model were obtained from four sources:

1. 126 drill holes with hydrostratigraphic unit boundaries selected on the basis of geophysical logs, cores, and (or) cuttings;

\footnotetext{
${ }^{4}$ Spatial data were stored and computations were made in Systeme International d'Unités (SI) units; therefore, spatial data are expressed in SI units in this report. Conversion factors are available in the Conversion Factors section.
}

2. stratigraphic contacts and faults defined from surface geologic mapping by Ham and others (1990) and digitized by Cederstrand (1996);

3. concealed faults from Scheirer and Hosford Scheirer (2006) and;

4. fault geometry, stratigraphic thickness, and tectonic history data compiled from geologic and hydrogeologic reports and maps.

Subsurface fault data from several geophysical surveys also were integrated into the geologic framework model. A helicopter electromagnetic (HEM) survey was flown over four areas or blocks of the eastern Arbuckle-Simpson aquifer. The HEM survey (Smith and others, 2009) consisted of 770 line kilometers and provided subsurface details of the electrical resistivity of the geology down to $200 \mathrm{~m}$ in depth. Several ground geophysical surveys also have been done in the eastern Arbuckle-Simpson aquifer. One of the HEM survey blocks substantiates the findings of Scheirer and Hosford Scheirer's (2006) gravity survey. In May of 2007, Scheirer and Aboud (2008) collected ground magnetic and gravity observations in the western part of the eastern Arbuckle-Simpson aquifer near Sulphur, Oklahoma, which complements previous gravity work (Scheirer and Hosford Scheirer, 2006) in CNRA.

\section{Model Construction}

Fault planes were modeled using about 20 major normal and reverse faults dipping 80 degrees and 65 degrees, respectively. Faults, and the proposed fault extensions on the western edge of the Hunton anticline (Scheirer and Hosford Scheirer, 2006), were modeled prior to the integration of stratigraphic control points. Drill-hole data provided elevation control for the modeled stratigraphic surfaces. The top of the Arbuckle-Timbered Hills hydrostratigraphic unit is considered to be the primary model reference horizon because this unit was constructed by using 89 wells with identifiable subsurface contacts. The top of the Simpson hydrostratigraphic unit was identified in 54 wells, but only 13 wells were drilled deep enough to reach the basement. The Simpson and basement surfaces were locally projected to an interpreted pre-erosion thickness. The post-Simpson hydrostratigraphic unit was defined in the modeling process as any rock volume between the top of the Simpson hydrostratigraphic unit and the DEM surface. The post-Simpson hydrostratigraphic unit has been removed by erosion over much of the modeled area. A more detailed description of the process used in the construction of the geologic framework model is available in Faith and others (2010).

Surface stratigraphic contacts from Cederstrand (1996) provided additional control points for the modeled surfaces by combining surface data with the corresponding subsurface drill-hole data. Numerous unconformities were noted in existing reports and were identified in geophysical logs. These depositional breaks (or gaps) are most prevalent on the 
SURFACE ELEVATION PROFILE
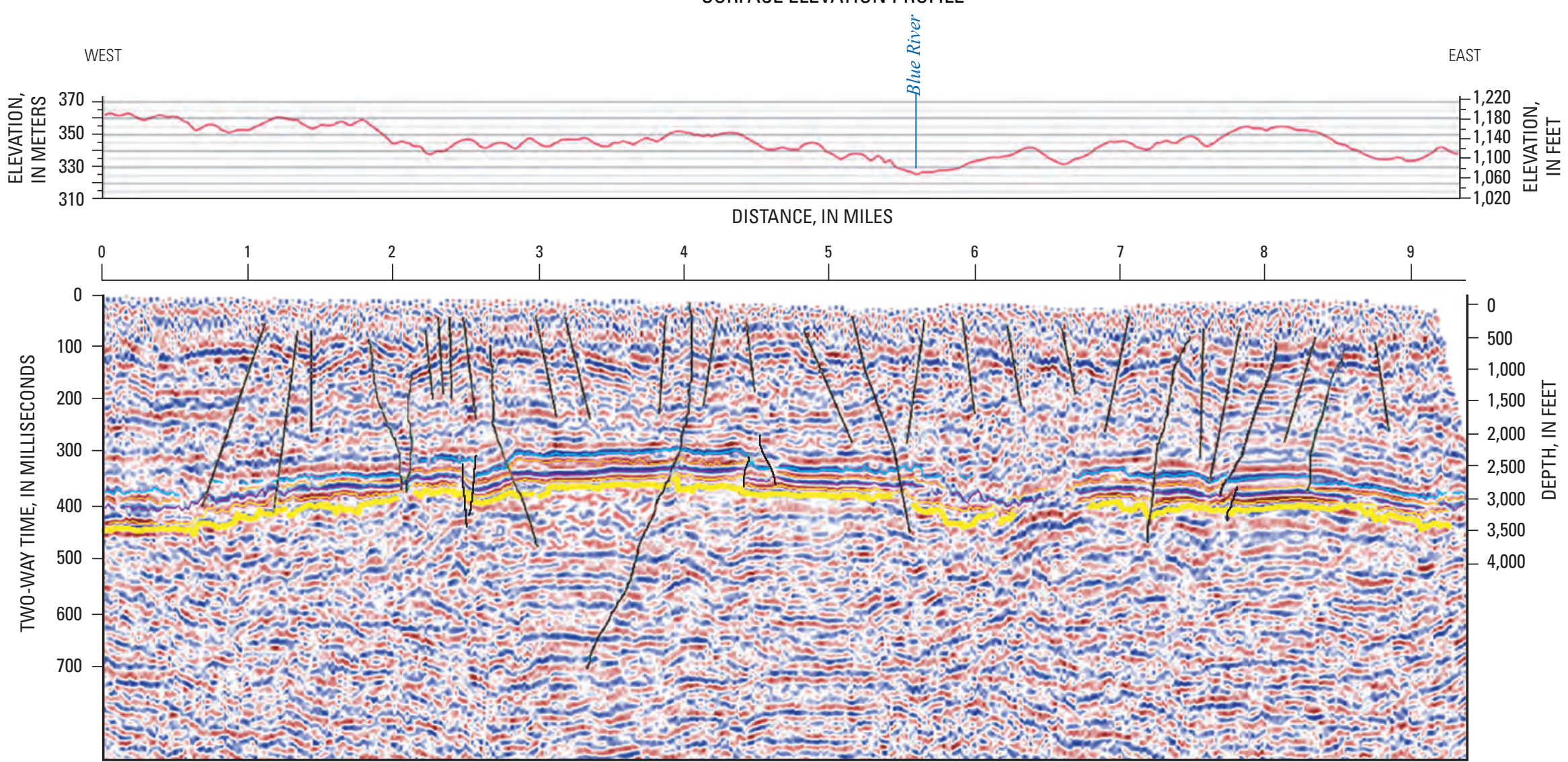

Trace of line shown in figure 7

Figure modified from Kennedy (2008)

EXPLANATION

Fault
Basement horizon

Figure 8. Seismic reflection line across the Hunton anticline showing interpreted basement horizon and faults. 
western flanks of the eastern Arbuckle-Simpson aquifer and are reflected throughout the model (figs. 7, 9-12).

The modeled surface elevation of basement rocks (fig. 9) ranges from about $300 \mathrm{~m}(980 \mathrm{ft})$ above the North American Vertical Datum of 1988 (NAVD 88) to about 1,900 $\mathrm{m}(6,200 \mathrm{ft})$ below NAVD 88 . The modeled thickness of the Arbuckle-Timbered Hills hydrostratigraphic unit (fig. 10) ranges in thickness from 0 (where the aquifer abuts igneous and metamorphic rocks) to more than $1,600 \mathrm{~m}(5,200 \mathrm{ft})$. Locally, more than half of this thickness has been removed by erosion; however, along the north and south flanks of the eastern Arbuckle Simpson aquifer, intense faulting has resulted in steeply dipping beds and stratigraphic overlap resulting in greater apparent thicknesses. Across the modeled area, the thickness of the Simpson hydrostratigraphic unit (fig. 11) ranges from 0 to more than $630 \mathrm{~m}(2,100 \mathrm{ft})$ as a result of faulting and surface erosion. The thickness of the post-Simpson hydrostratigraphic unit ranges from zero to more than $320 \mathrm{~m}(1,050 \mathrm{ft})$ on the western flank of the eastern
Arbuckle-Simpson aquifer (fig. 12). The surface and thickness maps (figures 9-12) are modified from Faith and others (2010); some contours were deleted where individual contours were difficult to discern, such as in areas with narrow contour spacing or at the edge of the map. Readers are referred to Faith and others (2010) for the original publication.

\section{Data Exported from the Geologic Framework Model}

Data from the geologic framework model of the eastern Arbuckle-Simpson aquifer provided the geologic data for the eastern Arbuckle-Simpson aquifer MODFLOW groundwaterflow model. The data were interpolated to the MODFLOW model nodes and exported as an ASCII file that listed the elevations of the tops and thicknesses of the post-Simpson, Simpson, and Arbuckle-Timbered Hills hydrostratigraphic units and the elevation of the top of the basement hydrostratigraphic unit.

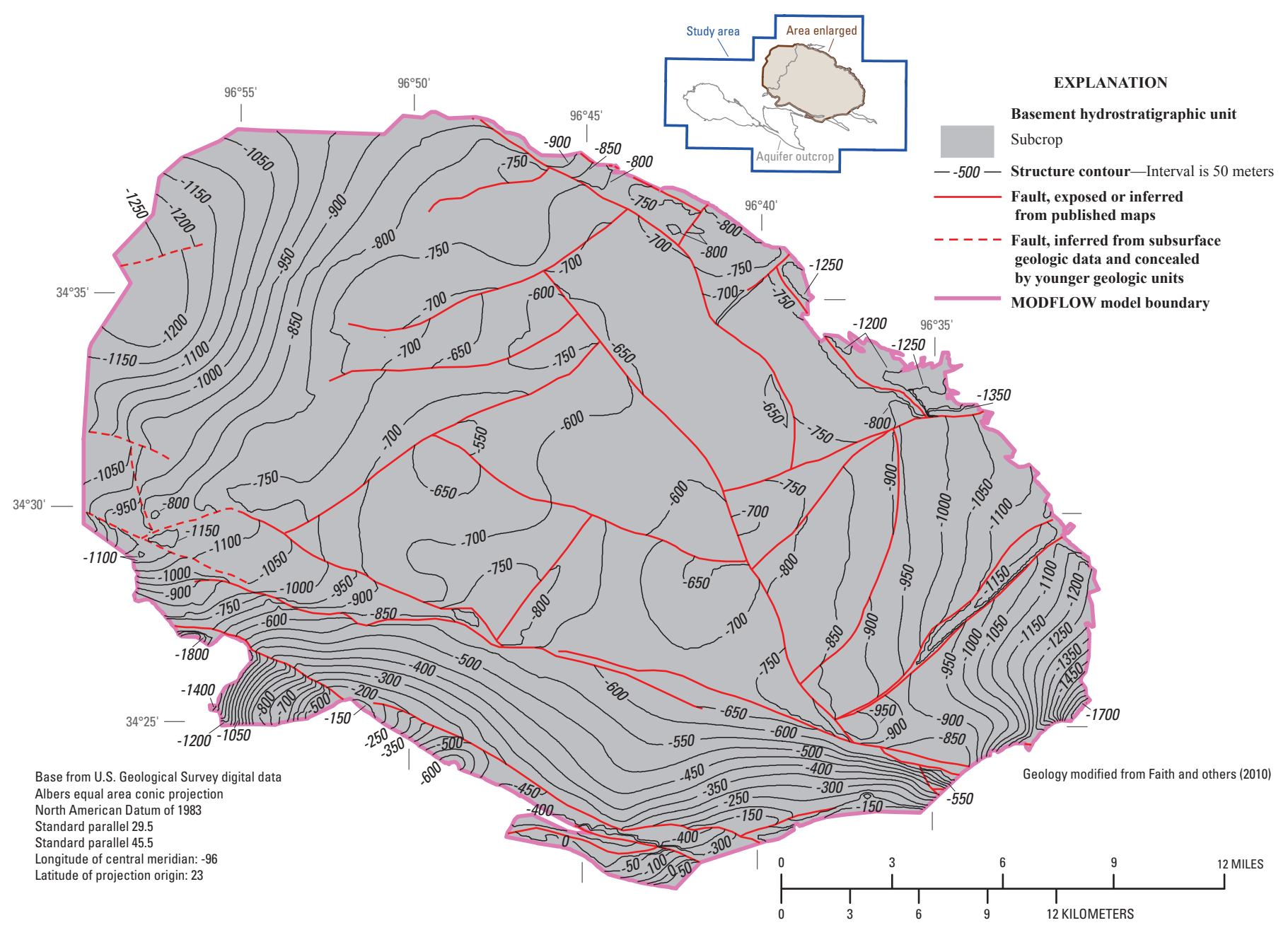

Figure 9. Structure contour map of the basement surface and faults modeled by the geologic framework model of the eastern Arbuckle-Simpson aquifer, south-central Oklahoma. 


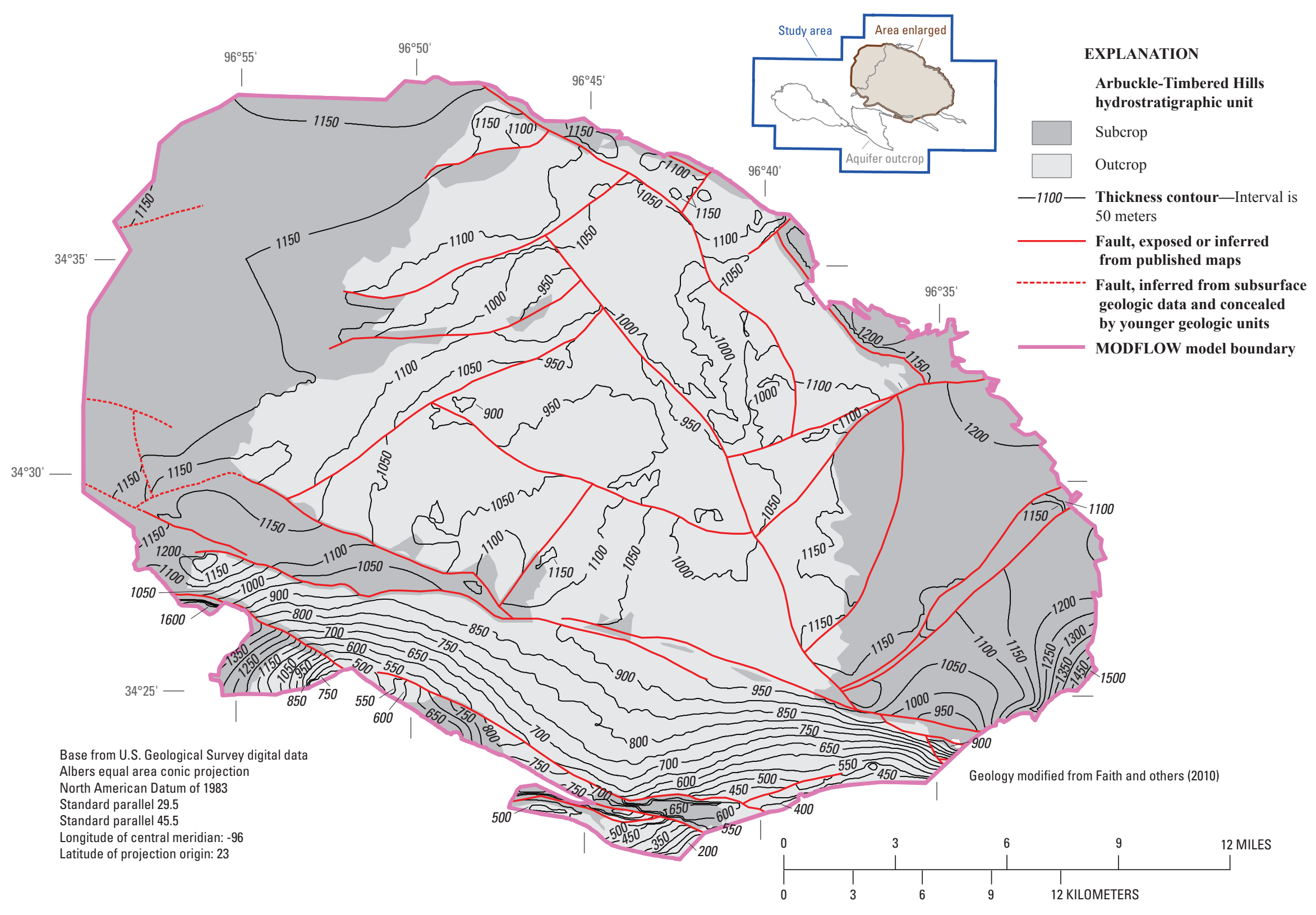

Figure 10. Thickness of the Arbuckle-Timbered Hills hydrostratigraphic unit and faults modeled by the geologic framework model of the eastern Arbuckle-Simpson aquifer, south-central Oklahoma. 


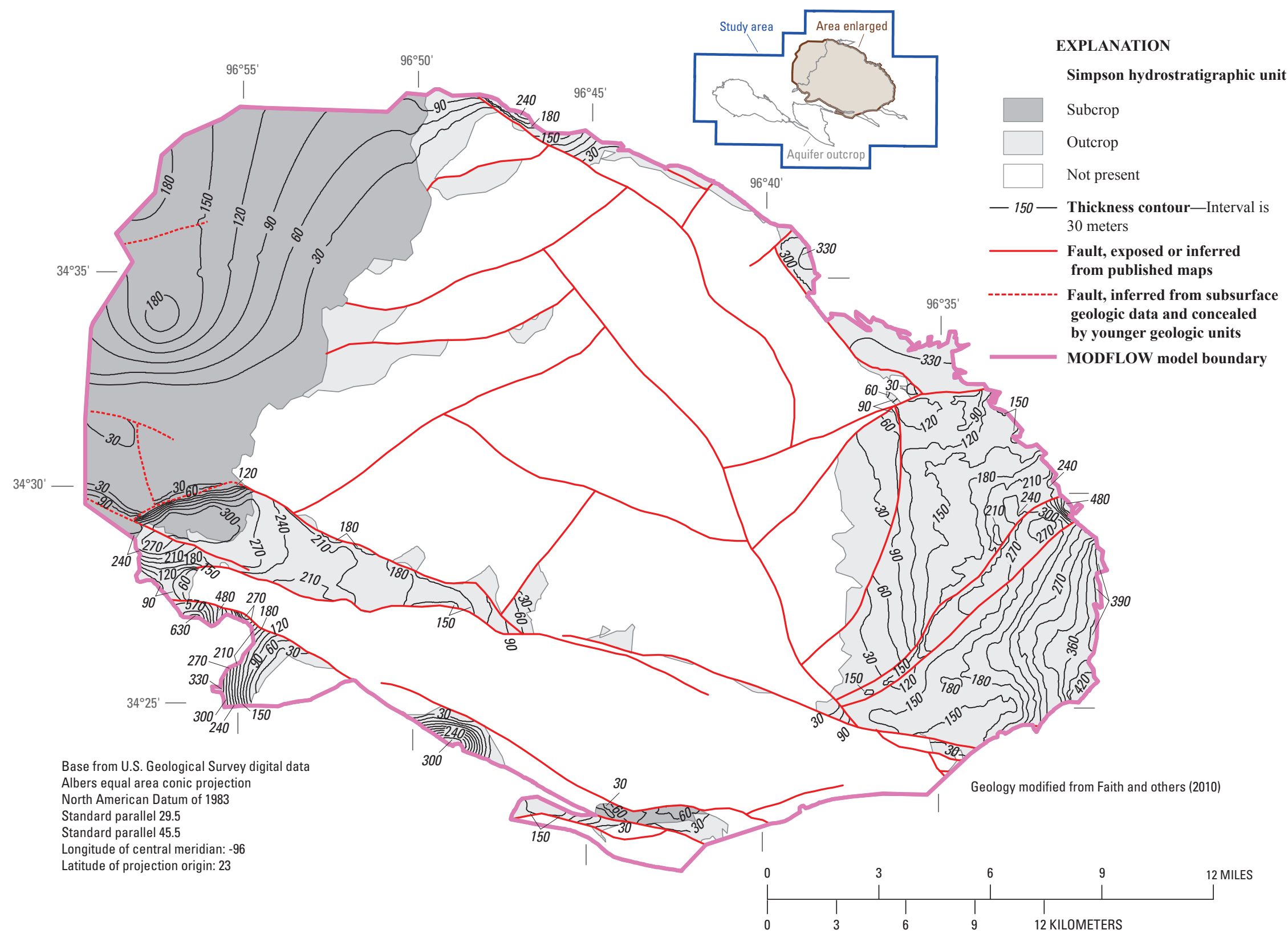

Figure 11. Thickness of the Simpson hydrostratigraphic unit and faults modeled by the geologic framework model of the eastern Arbuckle-Simpson aquifer, south-central Oklahoma. 


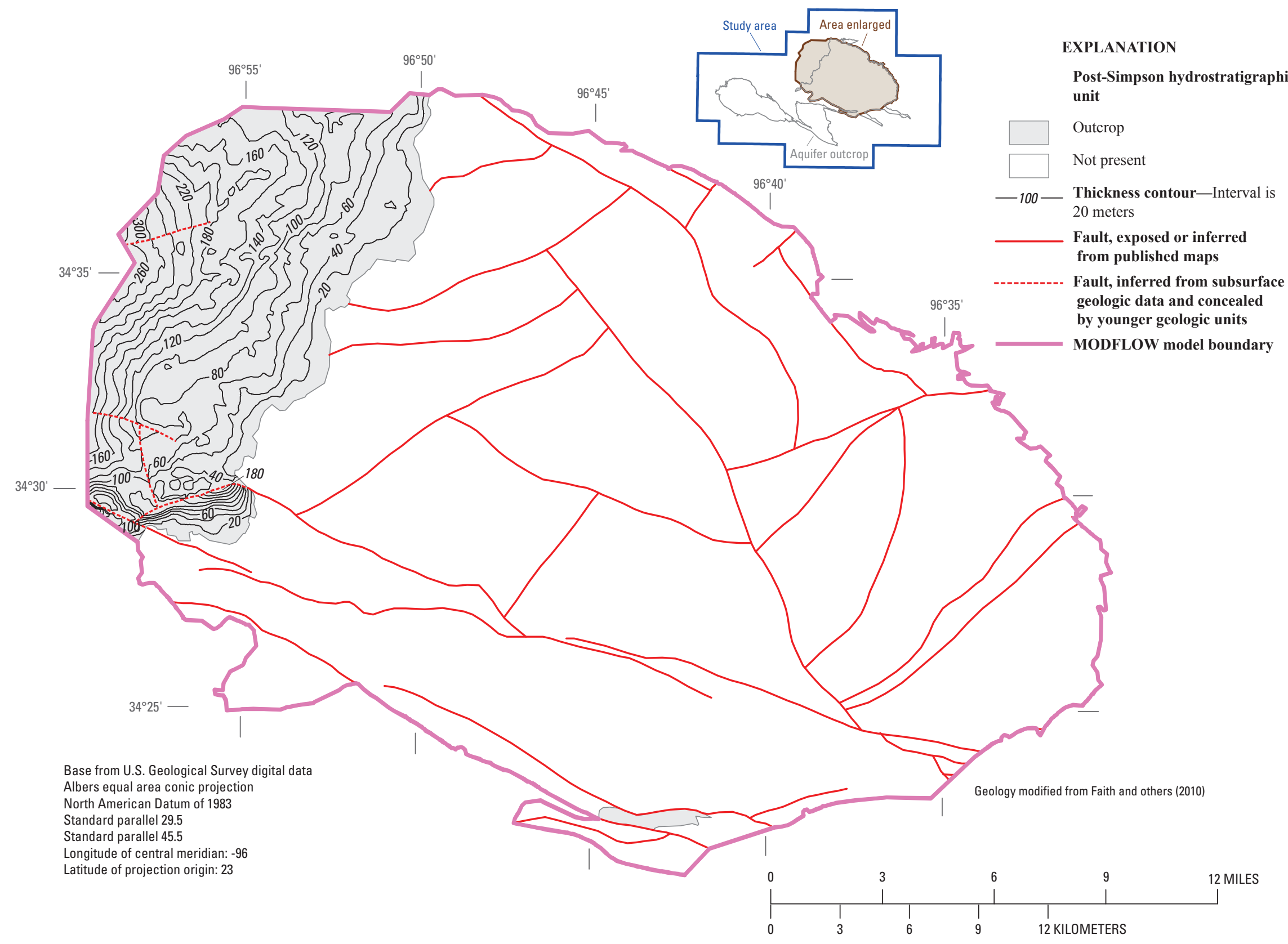

Figure 12. Thickness of the post-Simpson hydrostratigraphic unit and faults modeled by the geologic framework model of the eastern Arbuckle-Simpson aquifer, south-central Oklahoma. 


\section{Climate}

The study area has a moist, subhumid climate (Thornthwaite, 1948). Mean monthly precipitation, based on the 30-year average from 1971 to 2000 at Ada, Oklahoma, shown on figure 2, ranges from 1.84 inches in January to 5.71 inches in May, with an average annual precipitation of 41.54 inches (table 3). Annual precipitation from 1907 to 2008 for Ada, Oklahoma, is shown in figure 13, although the data for 1909, 1910, 1954, and 2001 are incomplete. The 30-year average is commonly cited as the average precipitation at Ada, however, the 30-year average for 1971-2000 is different than the long-term average from 1911 to 2008 , which is 39.29 inches (National Oceanic and Atmospheric Administration, 2009). Average monthly temperatures for Ada (for 1971-2000) range from $3.8^{\circ} \mathrm{C}$ in January and $27.7^{\circ} \mathrm{C}$ in July with an annual average of $16.2^{\circ} \mathrm{C}$ (table 4 ).

Most of the analysis of the hydrology of the ArbuckleSimpson aquifer presented in this report (for example, the calculation of recharge described in the Recharge subsection in the Groundwater section of this report) used data from
Table 3. Average monthly and average annual precipitation at Ada, Oklahoma (1971-2000).

[Data from Oklahoma Climatological Survey (2010)]

\begin{tabular}{lc}
\hline & Precipitation (inches) \\
\hline January & 1.84 \\
February & 2.22 \\
March & 3.67 \\
April & 3.83 \\
May & 5.71 \\
June & 4.52 \\
July & 2.72 \\
August & 3.10 \\
September & 4.57 \\
October & 3.89 \\
November & 3.10 \\
December & 2.39 \\
Annual & 41.54 \\
\hline
\end{tabular}

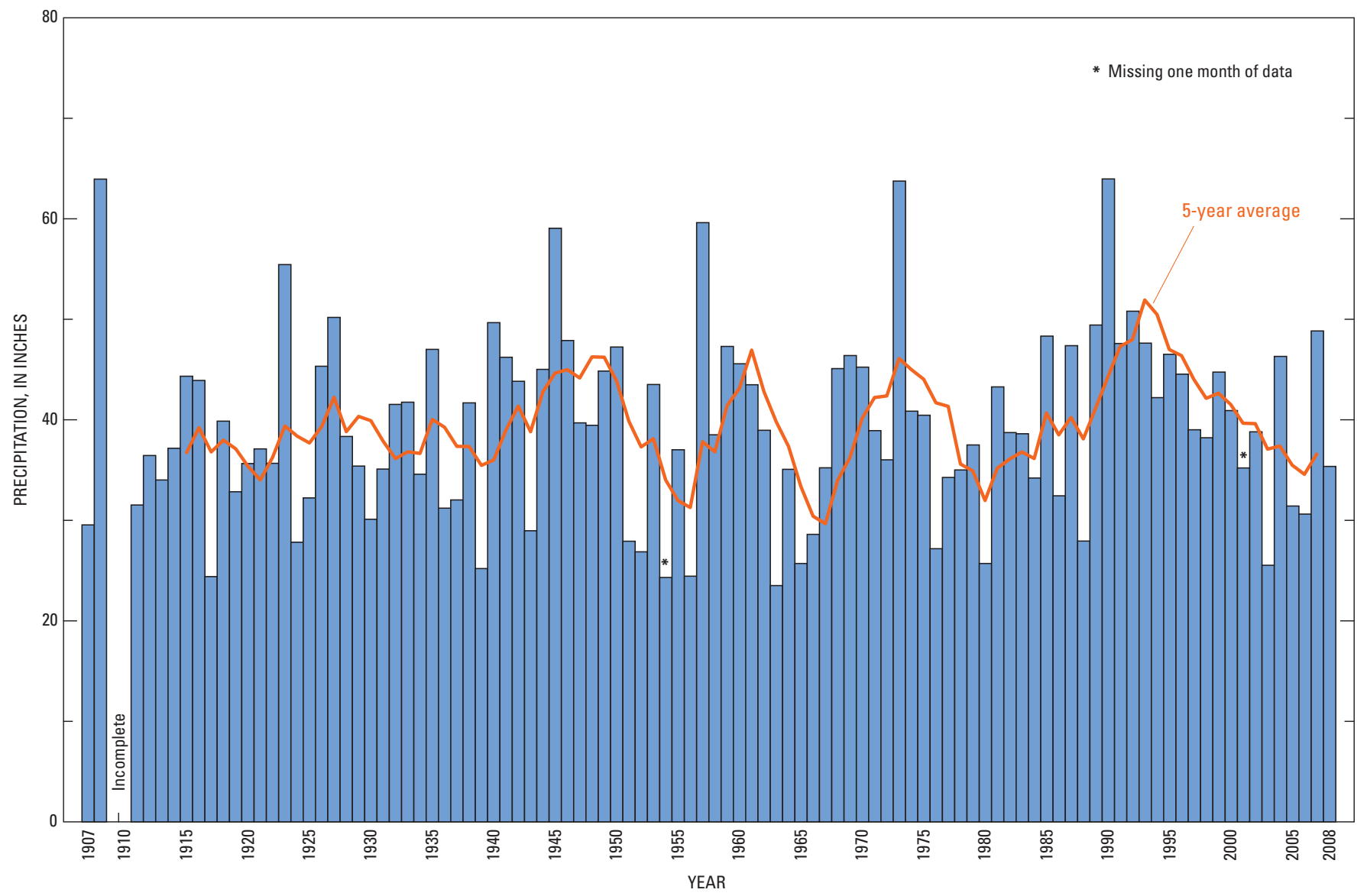

Figure 13. Annual precipitation at Ada, Oklahoma, 1907-2008. 
Table 4. Temperature data for Ada, Oklahoma (1971-2000).

[Data from National Climatic Data Center (2008)]

\begin{tabular}{lccc}
\hline & \multicolumn{3}{c}{ Mean temperature (degrees Celsius) } \\
\cline { 2 - 4 } & $\begin{array}{c}\text { Daily } \\
\text { maximum }\end{array}$ & $\begin{array}{c}\text { Daily } \\
\text { minimum }\end{array}$ & Average \\
\hline January & 9.9 & -2.4 & 3.8 \\
February & 13.4 & 0.2 & 6.8 \\
March & 18.3 & 4.7 & 11.5 \\
April & 23.0 & 9.1 & 16.1 \\
May & 26.8 & 14.3 & 20.6 \\
June & 30.8 & 18.9 & 24.8 \\
July & 33.8 & 21.5 & 27.7 \\
August & 33.6 & 20.8 & 27.2 \\
September & 29.4 & 16.5 & 22.9 \\
October & 23.9 & 10.4 & 17.2 \\
November & 16.6 & 4.1 & 10.4 \\
December & 11.4 & -0.8 & 5.3 \\
Annual & 22.1 & 9.8 & 16.2 \\
\hline
\end{tabular}

water years 2004 through 2008 (October 1, 2003, through September 30,2008). Monthly and annual precipitation data for Ada for water years 2004 through 2008 are listed in table 5 . Average annual precipitation for water years $2004-8$ was 38.82 inches, 2.72 inches less than the 30 -year average from 1971 to 2000, with water years 2004, 2006, and 2008 below average and water years 2005 and 2007 above average; water year 2007 was 14.57 inches more than the 30-year average from 1971 to 2000 at 56.11 inches. However, the average annual precipitation for water years $2004-8$ for Ada is only 0.47 inches less than the 1911-2008 average long-term precipitation. June 2007 was the wettest month ever recorded in the State of Oklahoma, based on the statewide average monthly rainfall (Oklahoma Climatological Survey, 2007).

Evaporation of water and transpiration of water by plants from the land surface often are difficult to distinguish and, therefore, are lumped by using the term "evapotranspiration." Most of the precipitation that falls in the study area returns to the atmosphere as evapotranspiration. Evapotranspiration was estimated by Fairchild and others (1990) by subtracting streamflow measured at streamgages from measured precipitation. Estimating evapotranspiration with this simple calculation assumes that (1) all precipitation that falls in a watershed either returns to the atmosphere as evapotranspiration or discharges down the stream channel (as runoff or groundwater discharge), (2) no groundwater inflows into or discharges across the basin boundary, and (3) no net change in soil moisture or groundwater storage exists. Fairchild and others (1990) estimated evapotranspiration to be about 31 inches per year, or about 80 percent of precipitation (on the basis of data from 1969 to 1971 and 1976 to 1979). A similar calculation was done for the current (2011) study. Precipitation was determined by using NEXRAD [an acronym for NEXt generation of weather RADar, (National Oceanic and Atmospheric Administration, 2011)] radar for the Blue River and Pennington Creek watersheds (B. Vieux, University of Oklahoma, written commun., 2008) and runoff was calculated from streamflow data from the USGS National Water Information System (NWIS) database for Blue River near Connerville (USGS streamgage number 07332390) and Pennington Creek near Reagan (07331300) (http://waterdata. usgs.gov/nwis). Average annual evapotranspiration computed for the current (2011) study for the 5-water-year period was 28.59 inches per year (80.04 percent of precipitation) in the Blue River watershed and 26.13 inches/year (76.37 percent of precipitation) in the Pennington Creek watershed (table 6). However, the assumptions for the method are not rigorously met in these two watersheds. As will be discussed in the Subsurface Watersheds section of this report, surface water and subsurface watersheds are not the same in these two watersheds, introducing some error into the calculations. Additionally, the amount of water in storage in groundwater and soil moisture was not explicitly measured as part of this study, but was likely to be different at the start and end of the 5 -water-year period, introducing additional error. Therefore, the amounts of evapotranspiration computed in this report should be considered to be estimates.

\section{Streamflow}

Perennial streams that originate in the Arbuckle-Simpson aquifer include Blue River, Buckhorn Creek, (Byrds) Mill Creek, Delaware Creek, Honey Creek, Mill Creek, Pennington Creek, Oil Creek, and Travertine Creek (fig. 14). Groundwater discharge from the aquifer maintains base flow to these streams, and many small streams. Blue River, which drains a large part of the eastern Arbuckle-Simpson aquifer, is the largest stream (based on mean daily streamflow) that originates in the study area (table 7).

Several streamgages in or near the study area were in operation prior to the start of the Arbuckle-Simpson Hydrology Study (fig. 14). A streamgage has been in operation on Blue River at Blue, Oklahoma, since 1936, but this gage is about $30 \mathrm{mi}$ south of the aquifer and outside the study area (and, therefore, is not shown on fig. 14). The discharge from Byrds Mill Spring (USGS streamgage number 07334200) to a creek has been gaged since 1959; however, some of the discharge from the spring is diverted to supply the City of Ada, and that discharge was not gaged until 1989. The National Park Service and the U.S. Geological Survey have operated streamgages on Antelope Spring at Sulphur, Oklahoma (07329849), since 1985 and on Rock Creek at Sulphur, Oklahoma (07329852), since 1989 in Chickasaw National Recreation Area. 
Table 5. Monthly and annual precipitation at Ada, Oklahoma, for water years 2004-8.

[A water year starts October 1 and ends September 30; National Oceanic and Atmospheric Administration (2009)]

\begin{tabular}{|c|c|c|c|c|c|c|c|c|c|c|c|c|c|}
\hline \multirow{2}{*}{$\begin{array}{c}\text { Water } \\
\text { year }\end{array}$} & \multicolumn{13}{|c|}{ Precipitation (inches) } \\
\hline & October & November & December & January & February & March & April & May & June & July & August & September & Total \\
\hline 2004 & 1.09 & 2.30 & 1.16 & 1.78 & 2.69 & 2.50 & 3.41 & 0.63 & 8.02 & 7.32 & 2.61 & 0.58 & 34.09 \\
\hline 2005 & 9.19 & 6.51 & 1.07 & 4.87 & 1.65 & 0.57 & 0.78 & 2.28 & 3.35 & 4.64 & 6.70 & 3.36 & 44.97 \\
\hline 2006 & 2.34 & 0.64 & 0.24 & 1.18 & 0.21 & 5.40 & 3.75 & 1.75 & 1.09 & 0.66 & 1.14 & 2.54 & 20.94 \\
\hline 2007 & 6.12 & 2.94 & 3.84 & 2.69 & 1.46 & 4.52 & 3.58 & 8.02 & 14.41 & 3.97 & 4.28 & 0.28 & 56.11 \\
\hline 2008 & 2.26 & 0.57 & 2.80 & 0.25 & 2.93 & 6.48 & 2.94 & 4.31 & 7.57 & 0.60 & 4.25 & 3.01 & 37.97 \\
\hline Average & & & & & & & & & & & & & 38.82 \\
\hline
\end{tabular}

Table 6. Annual evapotranspiration calculated for Blue River near Connerville, Oklahoma (07332390), and Pennington Creek near Reagan, 0klahoma (07331300), for water years 2004-8.

[*, annual precipitation derived from NEXRAD radar (B. Vieux, University of Oklahoma, written commun., 2008)]

\begin{tabular}{|c|c|c|c|c|c|c|}
\hline Station name & $\begin{array}{l}\text { Station } \\
\text { number }\end{array}$ & $\begin{array}{c}\text { Water } \\
\text { year }\end{array}$ & $\begin{array}{l}\text { Annual precipitation* } \\
\text { (inches) }\end{array}$ & $\begin{array}{l}\text { Annual runoff } \\
\text { (inches) }\end{array}$ & $\begin{array}{l}\text { Annual evapotranspiration } \\
\text { (inches) }\end{array}$ & $\begin{array}{l}\text { Evapotranspiration as } \\
\text { percent of precipitation }\end{array}$ \\
\hline Blue River near & 07332390 & 2004 & 32.45 & 4.13 & 28.32 & 87.27 \\
\hline \multirow[t]{5}{*}{ Connerville } & & 2005 & 42.49 & 9.43 & 33.06 & 77.81 \\
\hline & & 2006 & 24.63 & 3.93 & 20.70 & 84.04 \\
\hline & & 2007 & 49.68 & 15.83 & 33.85 & 68.14 \\
\hline & & 2008 & 32.59 & 5.56 & 27.03 & 82.94 \\
\hline & & Average & 36.37 & 7.78 & 28.59 & 80.04 \\
\hline \multirow{6}{*}{$\begin{array}{l}\text { Pennington Creek } \\
\text { near Reagan }\end{array}$} & 07331300 & 2004 & 32.80 & 5.02 & 27.78 & 84.70 \\
\hline & & 2005 & 40.15 & 10.71 & 29.44 & 73.33 \\
\hline & & 2006 & 22.79 & 4.78 & 18.01 & 79.03 \\
\hline & & 2007 & 47.02 & 18.56 & 28.46 & 60.53 \\
\hline & & 2008 & 32.01 & 5.04 & 26.97 & 84.25 \\
\hline & & Average & 34.95 & 8.82 & 26.13 & 76.37 \\
\hline
\end{tabular}


Table 7. Descriptive statistics for selected streamgages located on streams and springs originating on or near the Arbuckle-Simpson aquifer, south-central Oklahoma. $\left[\mathrm{ft}^{3} / \mathrm{s}\right.$, cubic feet per second; data from U.S. Geological Survey National Water Information System, http://waterdata.usgs.gov/nwis]

\begin{tabular}{|c|c|c|c|c|c|c|c|c|}
\hline $\begin{array}{l}\text { Station } \\
\text { number }\end{array}$ & Station name & $\begin{array}{l}\text { Period } \\
\text { of record }\end{array}$ & $\begin{array}{c}\text { Mean } \\
\text { flow }\left(\mathrm{ft}^{3} / \mathbf{s}\right)\end{array}$ & $\begin{array}{l}\text { Minimum } \\
\text { flow }\left(\mathrm{ft}^{3} / \mathrm{s}\right)\end{array}$ & $\begin{array}{l}\text { 25th percentile } \\
\text { flow }\left(\mathrm{ft}^{3} / \mathrm{s}\right)\end{array}$ & $\begin{array}{c}\text { Median } \\
\text { flow }\left(\mathrm{ft}^{3} / \mathrm{s}\right)\end{array}$ & $\begin{array}{l}\text { 75th percentile } \\
\text { flow }\left(\mathrm{ft}^{3} / \mathrm{s}\right)\end{array}$ & $\begin{array}{l}\text { Maximum } \\
\text { flow }\left(\mathrm{ft}^{3} / \mathrm{s}\right)\end{array}$ \\
\hline 07329780 & $\begin{array}{l}\text { Honey Creek below Turner Falls } \\
\text { near Davis }\end{array}$ & $\begin{array}{r}2004-10-01 \text { to } \\
2008-09-30\end{array}$ & 19.1 & 0.47 & 3.7 & 6.8 & 15 & 655 \\
\hline 07329849 & Antelope Spring at Sulphur & $\begin{array}{l}1985-11-20 \text { to } \\
1989-09-30 \\
2002-10-01 \text { to } \\
2008-09-30\end{array}$ & 2.74 & 0 & 1.1 & 2.7 & 4.0 & 11 \\
\hline 07329852 & Rock Creek at Sulphur & $\begin{array}{r}1989-10-01 \text { to } \\
2008-09-30\end{array}$ & 54.0 & 1.4 & 9.0 & 17 & 36 & 3,450 \\
\hline 07331200 & Mill Creek near Mill Creek & $\begin{array}{r}2006-09-07 \text { to } \\
2008-09-30\end{array}$ & 28.3 & 0.14 & 3.8 & 7.5 & 15 & 1,490 \\
\hline 07331295 & Pennington Creek east of Mill Creek & $\begin{array}{r}2006-09-09 \text { to } \\
2008-09-30\end{array}$ & 23.8 & 3.8 & 6.2 & 13 & 19 & 930 \\
\hline 07331300 & Pennington Creek near Reagan & $\begin{array}{r}2003-10-01 \text { to } \\
2008-09-30\end{array}$ & 43.0 & 9.9 & 18 & 24 & 38 & 2,560 \\
\hline 07332390 & Blue River near Connerville & $\begin{array}{l}1976-10-01 \text { to } \\
1979-09-30 \\
2003-10-01 \text { to } \\
2008-09-30\end{array}$ & 82.7 & 21 & 40 & 49 & 67 & 6,330 \\
\hline 07334200 & $\begin{array}{l}\text { Byrds Mill Spring near } \\
\text { Fittstown (combined flow) }\end{array}$ & $\begin{array}{r}1989-12-20 \text { to } \\
2008-09-30\end{array}$ & 18.5 & 4.6 & 15 & 18 & 22 & 43 \\
\hline
\end{tabular}




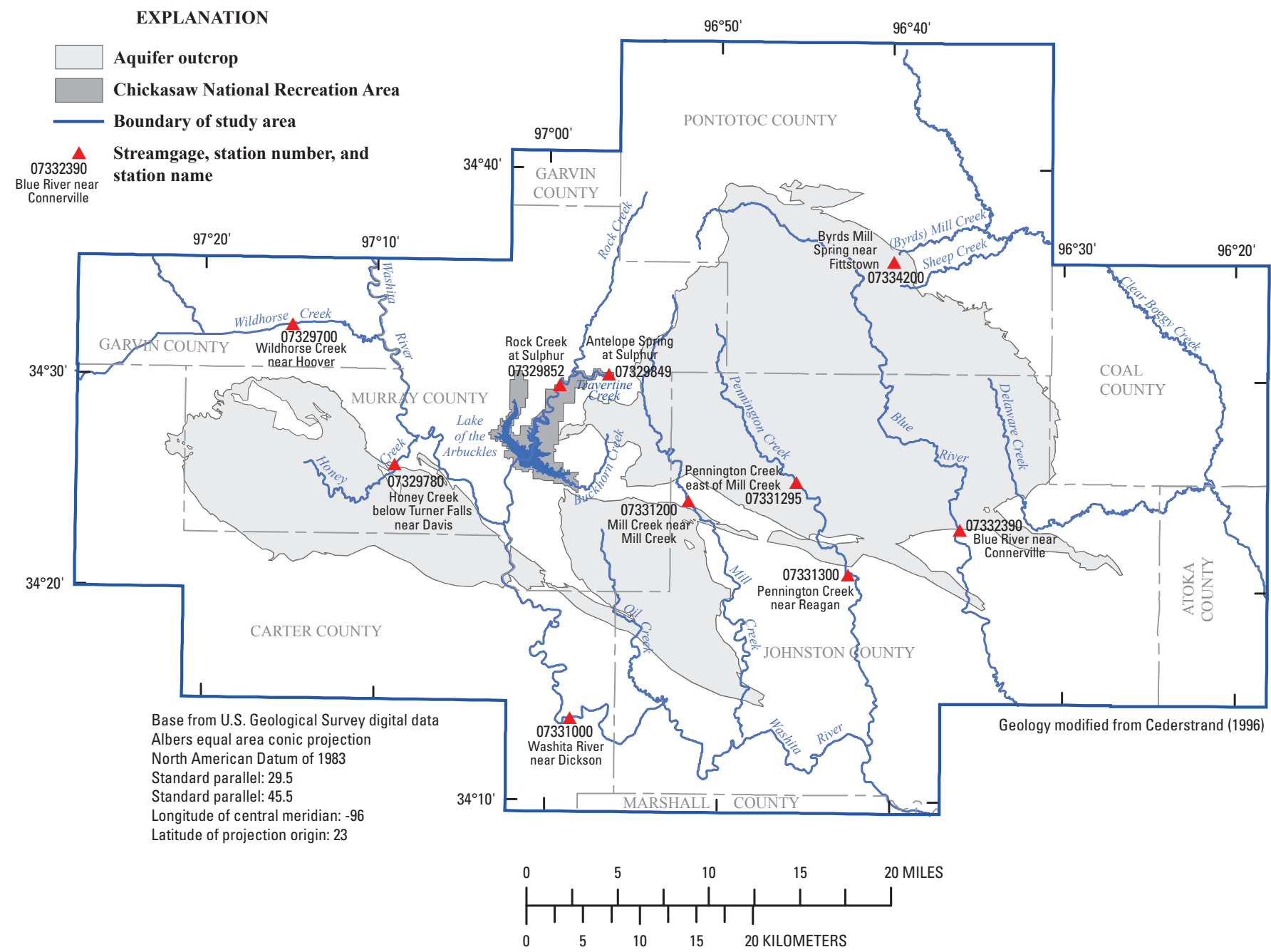

Figure 14. Streamgages located in the study area, south-central Oklahoma.

Streamgages were installed on Blue River near Connerville (07332390), Pennington Creek near Reagan (07331300), and Honey Creek below Turner Falls near Davis (07329780) as part of the Arbuckle-Simpson Hydrology Study. The streamgage on Blue River near Connerville was installed at the same location used during the study described in Fairchild and others (1990). Streamgages were installed on Mill Creek near the town of Mill Creek (07331200) and on Pennington Creek east of the town of Mill Creek (07331295) during this study. Descriptive statistics were calculated for streamgages near the Arbuckle-Simpson aquifer and are shown in table 7.

Descriptive statistics were not calculated for the streamgage on the Washita River near Dickson (07331000) because only a small part of this stream's drainage area is on the Arbuckle-Simpson aquifer. Water-level measurements near the Washita River in the late 1970s by Fairchild and others (1990) show that the potentiometric surface sloped toward the Washita River; therefore, groundwater was discharging to the river and the river did not recharge the aquifer, but no measurements of streamflow were made as part of this study that would quantify the discharge of groundwater from the Arbuckle-Simpson aquifer to the Washita River.

Base flow, the flow in a stream channel that represents groundwater discharge and not runoff from storms, was computed for Blue River near Connerville (07332390) and Pennington Creek near Reagan (07331300) by using the PART program (Rutledge, 1998). The PART program scans the streamflow record from a streamgage for days that fit a requirement of antecedent recession, designates base flow to be equal to streamflow on these days, and linearly interpolates the daily record of base flow for days that do not fit the requirement of antecedent recession (Rutledge, 1998). Flow in Blue River near Connerville was computed to be 66 percent base flow and flow in Pennington Creek near Reagan was computed to be 76 percent base flow for the 5-water-year 
period from October 1, 2003, to September 30, 2008. Flow in Byrds Mill Spring is only groundwater, with no surface-water components, and, therefore, is 100 percent base flow.

Besides determining base flow by using the PART program, measurements of base flow were made by measuring stream discharge at times when runoff was absent in stream channels. Base-flow measurements were made in 1995 during a joint USGS / U.S. Environmental Protection Agency study of the eastern Arbuckle-Simpson aquifer, and from 2004 through 2007, when the OWRB made quarterly measurements on small streams that discharge from the Arbuckle-Simpson aquifer. The streamgages, synoptic discharge measurement sites, and streamflow discharge measurements from one of the synoptic measurements (made during February 19-22, 2007), are shown on figure 15 .
Streams originating on the Arbuckle-Simpson aquifer generally are gaining streams, as shown by the streamflow discharge data on figure 15 for the time period February 19-22, 2007; the other synoptic stream discharge measurements (but not shown on fig. 15) also show ArbuckleSimpson streams to be gaining. However, small losses in flow on Blue River were documented by Savoca and Bergman (1994). That report described streamflow measurements conducted 17 times in a 32-day period (August 17, 1992, to September 18, 1992) along the upper reach of Blue River and showed that upper Blue River is primarily a gaining stream. However, that report described small losses at a few sites. One section of Blue River lost on average 1.1 cubic foot per second $\left(\mathrm{ft}^{3} / \mathrm{s}\right)$, or about 6.1 percent of the flow as measured at the upper measurement site (Savoca and Bergman, 1994). However, during this same time period, two high-capacity

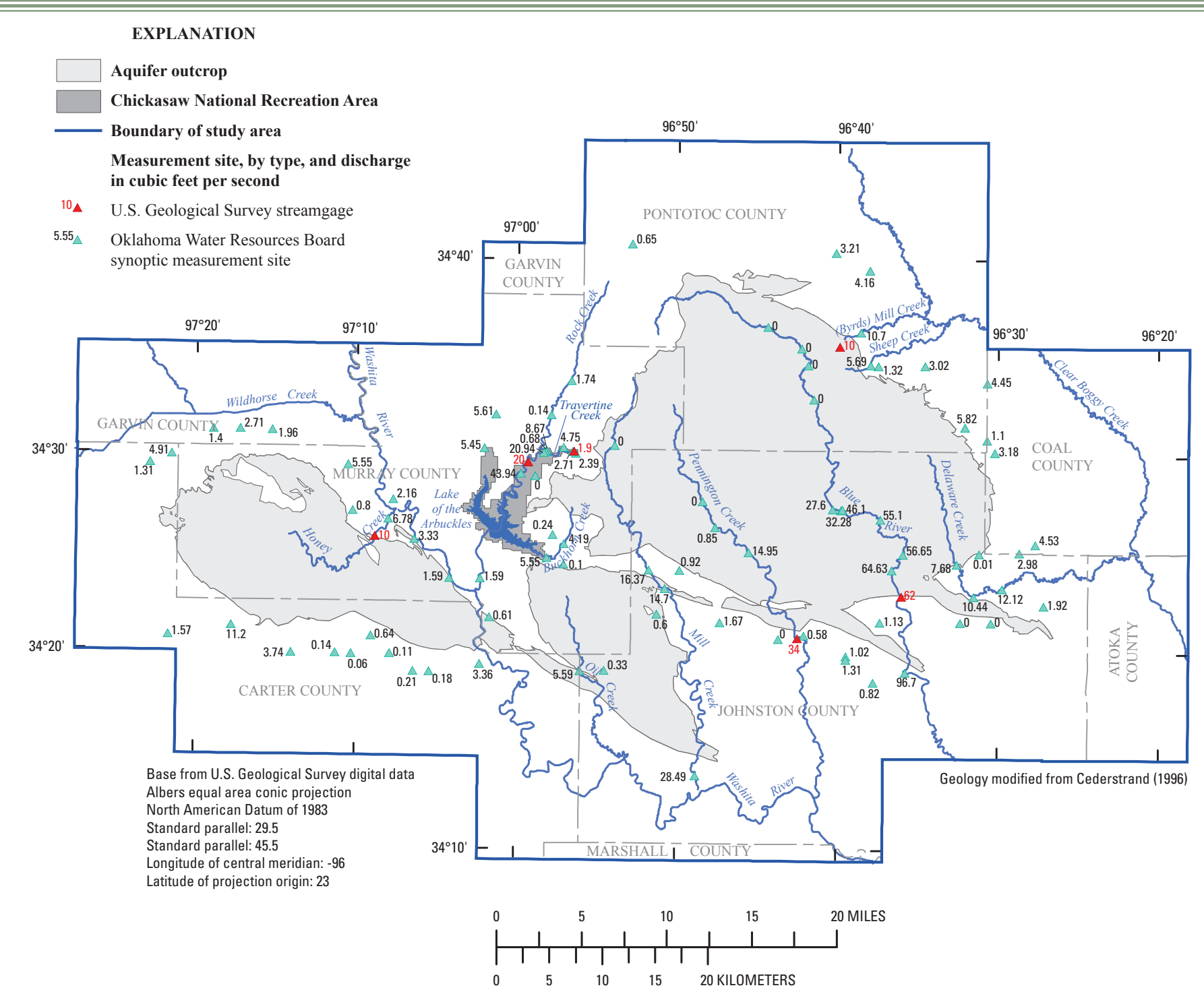

Figure 15. Streamgages, synoptic discharge measurement sites, and streamflow discharge for February 19-22, 2007, for streams on or near the Arbuckle-Simpson aquifer, south-cental Oklahoma. 
wells about 2 mi east of Blue River were pumping at a combined rate of $3,900 \mathrm{gal} / \mathrm{min}$, or about $8.7 \mathrm{ft}^{3} / \mathrm{s}$, so the loss in flow on Blue River may have been the result of the pumping. Streamflow losses along Blue River documented by Savoca and Bergman (1994) may have been caused by (1) pumping from nearby wells, (2) uncertainty in streamflow measurements (streamflow measurement classified as "good" by the U.S. Geological Survey are considered to have an uncertainty of plus or minus 5 percent), (3) exchange of water between the stream and shallow groundwater system (known as "hyporheic exchange"), or (4) loss from the Blue River drainage basin to Byrds Mill Spring. The subsurface watershed of Byrds Mill Spring extends beneath the surface watershed of upper Blue River; see the Subsurface Watersheds section of this report. Therefore, available data show that ArbuckleSimpson streams are predominantly gaining streams.

\section{Springs}

Many springs discharge from the Arbuckle-Simpson aquifer. The USGS National Water Information System (NWIS) database lists 140 springs in the study area (fig. 16). Many of the springs are near the boundary of the aquifer outcrop at the downgradient end of the groundwater-flow system where the more permeable Arbuckle-Timbered Hills and Simpson hydrostratigraphic units abut the less permeable basement and post-Simpson hydrostratigraphic units. During most years, discharge from springs maintains flow in the larger streams in the study area in the absence of rainfall. Byrds Mill Spring, with an average annual discharge [based on data from the USGS NWIS database (http://waterdata.usgs.gov/nwis) for a period of record from 1990 to 2005] of $18.5 \mathrm{ft}^{3} / \mathrm{s}$, is the largest spring in Oklahoma and serves as the primary water supply for the City of Ada.

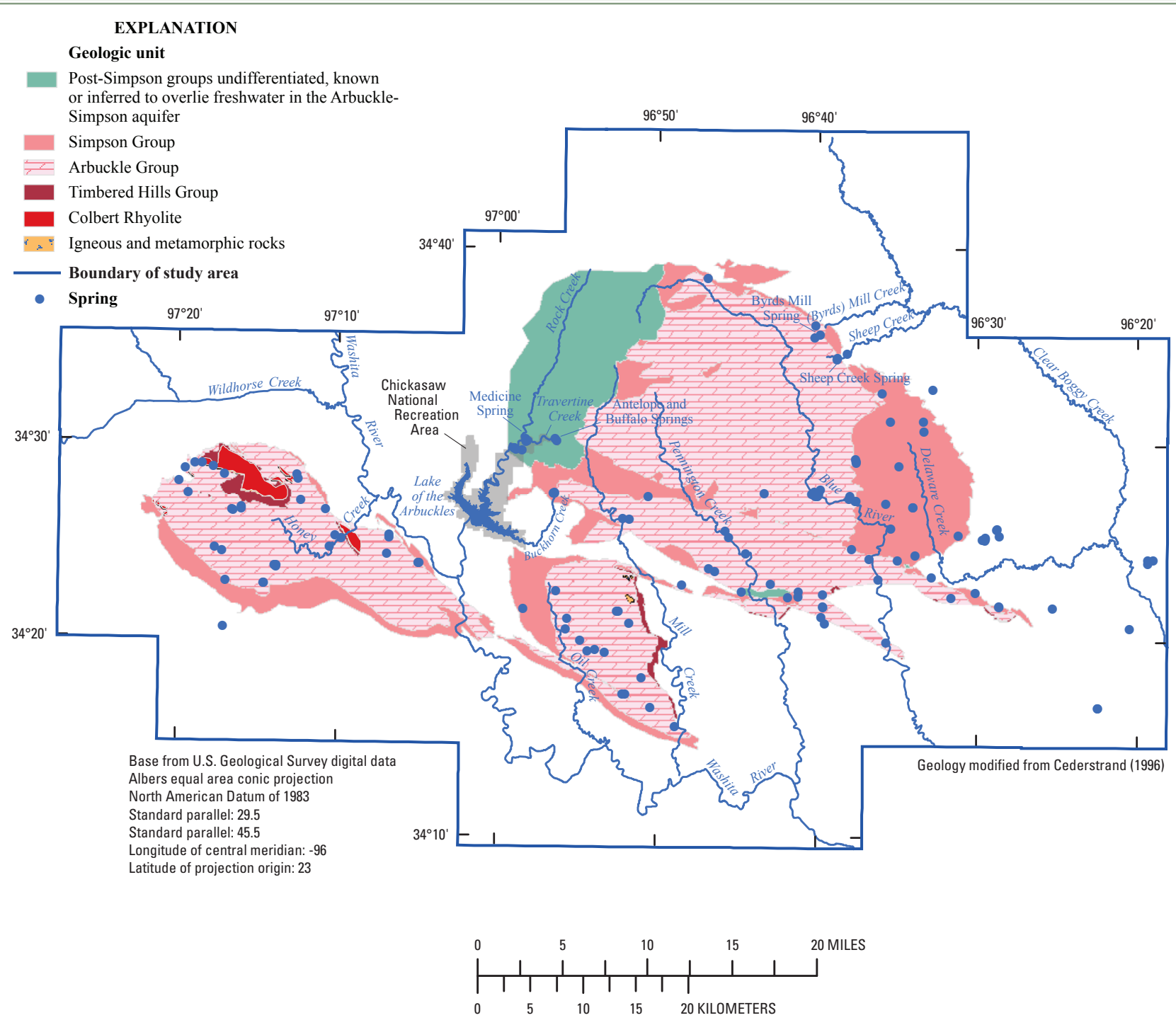

Figure 16. Springs listed in the U.S. Geological Survey National Water Information System database in the Arbuckle-Simpson aquifer study area, south-central Oklahoma. 
Springs in Chickasaw National Recreation Area (CNRA) near Sulphur are outside of the outcrop of the aquifer, but are supplied by water from the aquifer that originates as recharge on the outcrop and flows west under the post-Simpson hydrostratigraphic unit, then flows upward through the post-Simpson. Antelope and Buffalo Springs are freshwater springs in the eastern part of CNRA and small mineral springs are present in the western part of CNRA. These freshwater and mineral springs are thought to indicate the location of the freshwater/saline water transition zone at the edge of the freshwater flow system (Christenson and others, 2009).

Water samples were collected from 32 wells ( 30 relatively shallow wells, less than $500 \mathrm{ft}$ deep, and 2 deep wells) and 5 springs, including Byrds Mill Spring, as part of the Arbuckle-Simpson Hydrology Study and analyzed for major ions, trace elements, isotopes of oxygen and hydrogen, dissolved gases, and age-dating tracers (Christenson and others, 2009). The major-ion chemistry of the water samples from springs was similar to the major-ion chemistry of water from the sampled wells, indicating that the water discharging from springs is of the same origin as water in wells completed in the aquifer (Christenson and others, 2009). The dissolved gas content of water samples from springs was different from the dissolved gas content of water samples from most wells. Water samples from springs contained dissolved gases, such as terrigenic helium, indicating that the spring discharge probably represents a mixture of water from shallow and deep parts of the aquifer; whereas, most samples from wells appeared to represent shallow groundwater. Multiple flow paths often converge at springs, and although the water samples from these sites had modern groundwater ages, the terrigenic helium in these samples indicates that at least some fraction of the water from these springs has flowed along a long, deep flow path before discharge.

\section{Groundwater}

The primary source of groundwater in the ArbuckleSimpson aquifer is diffuse recharge from precipitation in the outcrop area. Recharge begins as precipitation on the land surface and infiltrates into the soil. Some of the soil moisture returns to the atmosphere from evaporation and transpiration by plants, but some fraction moves downward through the soil zone, through the unsaturated zone, and eventually becomes part of the water in the saturated zone. Groundwater moves through pores, fractures, and solution cavities in the aquifer from areas of high head (elevation) to areas of low head along streams and springs and discharges to those streams and springs.

\section{Extent of Fresh Groundwater}

The hydrostratigraphic units that form the ArbuckleSimpson aquifer contain fresh and saline water; for this study, the extent of the Arbuckle-Simpson aquifer is considered to be that part of those hydrostratigraphic units that produce freshwater. More than one definition of freshwater is available. Alley (2003) defines freshwater to be water with less than 1,000 milligrams per liter $(\mathrm{mg} / \mathrm{L})$ dissolved solids. The OWRB regulates the withdrawal and use of fresh groundwater, which is defined as groundwater with less than $5,000 \mathrm{mg} / \mathrm{L}$ dissolved solids (Oklahoma Water Resources Board, 2009). Insufficient data are available to map the transition of fresh to saline water in the Arbuckle-Simpson aquifer, regardless of the definition of fresh groundwater, and, therefore, the extent of fresh groundwater is described in general terms.

Freshwater in the Arbuckle-Simpson aquifer has low dissolved solids concentrations. Christenson and others (2009) reported that dissolved solids concentrations of water samples from 5 springs and 24 wells (one well was $1,400 \mathrm{ft}$ deep, another well was $775 \mathrm{ft}$ deep, but the other 22 wells were less than $300 \mathrm{ft}$ deep) producing water from the Arbuckle-Simpson aquifer ranged from 222 to $1,250 \mathrm{mg} / \mathrm{L}$, with a median of $347 \mathrm{mg} / \mathrm{L}$ and an interquartile range (data ranging from the 25 th to the 75 th percentiles) of only 331 to $384 \mathrm{mg} / \mathrm{L}$. All water samples from wells and springs reported in Christenson and others (2009) and Fairchild and others (1990) from the Arbuckle-Simpson outcrop area produced freshwater, indicating that the outcrop area of the Arbuckle-Simpson aquifer generally produces freshwater.

The depth of fresh groundwater in the outcrop area is not known, but the few deep wells drilled in the outcrop do not produce saline water. A test well [N34 $27^{\prime}$ latitude, W96 39' longitude, North American Datum of 1983 (NAD 83), shown as Test Well on fig. 2] was drilled to a depth of $1,820 \mathrm{ft}$ as part of this study and produced freshwater. All of the City of Ada wells, on the northeastern part of the eastern Arbuckle-Simpson aquifer, are deeper than $900 \mathrm{ft}$ and produce freshwater, and a high-capacity well, located at about $\mathrm{N} 34^{\circ}$ $31^{\prime}$ latitude, $\mathrm{W}^{\circ} 6^{\circ} 55^{\prime}$ longitude (NAD 83), is $1,116 \mathrm{ft}$ deep and produces freshwater. Dissolved solids concentrations from water samples collected from a well (approximate location N34 $32^{\prime}$ latitude, W96 $50^{\circ}$ longitude, NAD 83) in 1966 were less than $375 \mathrm{mg} / \mathrm{L}$ to a depth of 2,000 ft (Fairchild and others, 1990). Analysis of drill stem tests from three petroleum bore holes on the eastern Arbuckle-Simpson aquifer indicates freshwater at depths that range from 1,421 to about $1,834 \mathrm{ft}$ (Puckette and others, 2009).

Freshwater is known to extend beyond the aquifer outcrop near the City of Sulphur, Oklahoma, and CNRA (Christenson and others, 2009), where groundwater flows west from the outcrop of the eastern Arbuckle-Simpson aquifer and becomes confined beneath the post-Simpson hydrostratigraphic unit. Groundwater flowing beneath the post-Simpson hydrostratigraphic unit discharges to springs; creeks, such as Travertine and Rock Creeks; and wells, some of which are flowing (artesian). A few wells produce freshwater from the Arbuckle-Simpson aquifer just west of Rock Creek, west of Sulphur, indicating freshwater circulates at least that far to the west. The precise extent of the freshwater in the Arbuckle-Simpson aquifer beneath 
the post-Simpson hydrostratigraphic unit is not known. The zone where freshwater circulation is inferred west of the outcrop of the eastern Arbuckle-Simpson aquifer is shown on figures in this report as "post-Simpson groups undifferentiated, known or inferred to overlie freshwater in the Arbuckle-Simpson aquifer."

The transition from fresh to saline water in the ArbuckleSimpson aquifer is observed at specific locations, which mark the end of freshwater circulation in the aquifer:

1. Hanson and Cates (1994) reported that dissolved solids concentrations in water samples from springs in CNRA increase from east to west. They reported that dissolved solids concentration increased from $293 \mathrm{mg} / \mathrm{L}$ from Antelope and Buffalo Springs to 4,520 mg/L at Medicine Spring, a distance of less than $3 \mathrm{mi}$. This increase in dissolved solids concentrations in water samples from wells and springs in and near CNRA is likely because of mixing of fresh groundwater originating from recharge on the outcrop of the aquifer and a small amount of brine from the saline part of the aquifer (Christenson and others, 2009).

2. A 1,400 -ft-deep well at about $\mathrm{N} 34^{\circ} 27^{\prime}$ latitude W96 $33^{\prime}$ longitude (NAD 83) in Johnston County and in the aquifer outcrop was sampled on October 21, 2004. The dissolved solids concentration of the water sample was $768 \mathrm{mg} / \mathrm{L}$ and the age of groundwater produced from this well was calculated from the carbon-14 concentration to be 34,000 years (Christenson and others, 2009). The 34,000 -year carbon-14 age of water from this well probably indicates that the water produced from this well is not part of the freshwater circulation in the aquifer.

Outside of the freshwater zone, water chemistry changes quickly and becomes saline. Beyond the outcrop area of the aquifer, the Arbuckle and Simpson Groups contain brine and are major producers of oil and gas. Boyd (2002) shows oil and gas fields in contact with the aquifer at the northern extent of the western Arbuckle-Simpson aquifer at about N34 $30^{\prime}$ latitude, $\mathrm{W} 97^{\circ} 10^{\prime}$ longitude and at the northern extent of the eastern Arbuckle-Simpson aquifer at about N34 $38^{\prime}$ latitude, W96 $6^{\circ} 40^{\prime}$ longitude. An oil well, completed in the Simpson Group about 4 mi west of Sulphur, Oklahoma, was sampled as part of the Arbuckle-Simpson Hydrology Study. The dominant dissolved constituents in the water from this well were sodium and chloride, with a chloride concentration of $54,400 \mathrm{mg} / \mathrm{L}$ (Christenson and others, 2009).

\section{Aquifer Confinement}

The Arbuckle-Simpson aquifer is confined and unconfined in different parts of the study area. The aquifer is confined on the western part of the eastern Arbuckle-Simpson aquifer by the post-Simpson hydrostratigraphic unit (fig. 12). The confining properties of the post-Simpson hydrostratigraphic unit are thought to be the result of cemented conglomerates and shales in the Pennsylvanianage Vanoss Group. Further indication that the western part of the eastern Arbuckle-Simpson aquifer is confined includes numerous flowing wells near Sulphur, and carbon-14 dating of water samples from the Vendome flowing well (fig. 2) that indicated the age of the water to be 10,500 years (Christenson and others, 2009). Unconfined conditions are indicated where the Arbuckle-Timbered Hills hydrostratigraphic unit is at land surface and no confining layer is present. Indications that the Arbuckle-Timbered Hills hydrostratigraphic unit is unconfined include (1) water levels rise rapidly in wells in response to precipitation (fig. 17), and (2) groundwater samples from wells in the outcrop of the Arbuckle Group were dated as post1950 , meaning the water resident in that part of the aquifer at the time the samples were collected (2004-6) was recharged recently. However, Fairchild and others (1990) reported that "information from drillers and land owners suggests that the upper few hundred feet of the Arbuckle Group has a much lower permeability than the lower part." Rocks in the upper parts of a test well drilled for this study (shown as Test Well on fig. 2) appeared to be dry and produced little water, but as the well was drilled deeper (at a depth of about $300 \mathrm{ft}$ ) the test hole began to produce water and the water level rose to about $25 \mathrm{ft}$ below the surface, indicative of a confined aquifer. Therefore, in the outcrop area, the Arbuckle-Timbered Hills hydrostratigraphic unit may function as a confined and unconfined aquifer.

The Simpson Group includes sandstones, shales, and limestones that transmit substantial quantities of water horizontally and yield sufficient quantities of water to wells, allowing it to be considered an aquifer. However, several characteristics indicate that the Simpson Group also may act as a confining layer. These characteristics are (1) a 1,400-ft-deep flowing well drilled through the Simpson Group into the Arbuckle Group (located at about N34 ${ }^{\circ} 27^{\prime}$ latitude, W96 $33^{\prime}$ longitude, NAD 83), (2) the hydraulic gradients on the potentiometric maps (as described in the Potentiometric Surfaces section) are larger in the Simpson Group exposures than in the adjacent Arbuckle Group, and (3) a group of springs along Blue River on the outcrop of the Arbuckle Group immediately before Blue River flows across the Simpson Group. Springs can form at the contact between hydrostratigraphic units with different hydraulic conductivities; groundwater flowing through the more transmissive unit is forced to discharge from the aquifer by the less transmissive unit.

\section{Potentiometric Surfaces}

A potentiometric surface is a calculated imaginary surface, the topography of which reflects geographic variation in the fluid potential of the formation water in an aquifer (Dahlberg, 1994). The elevation of the potentiometric surface 


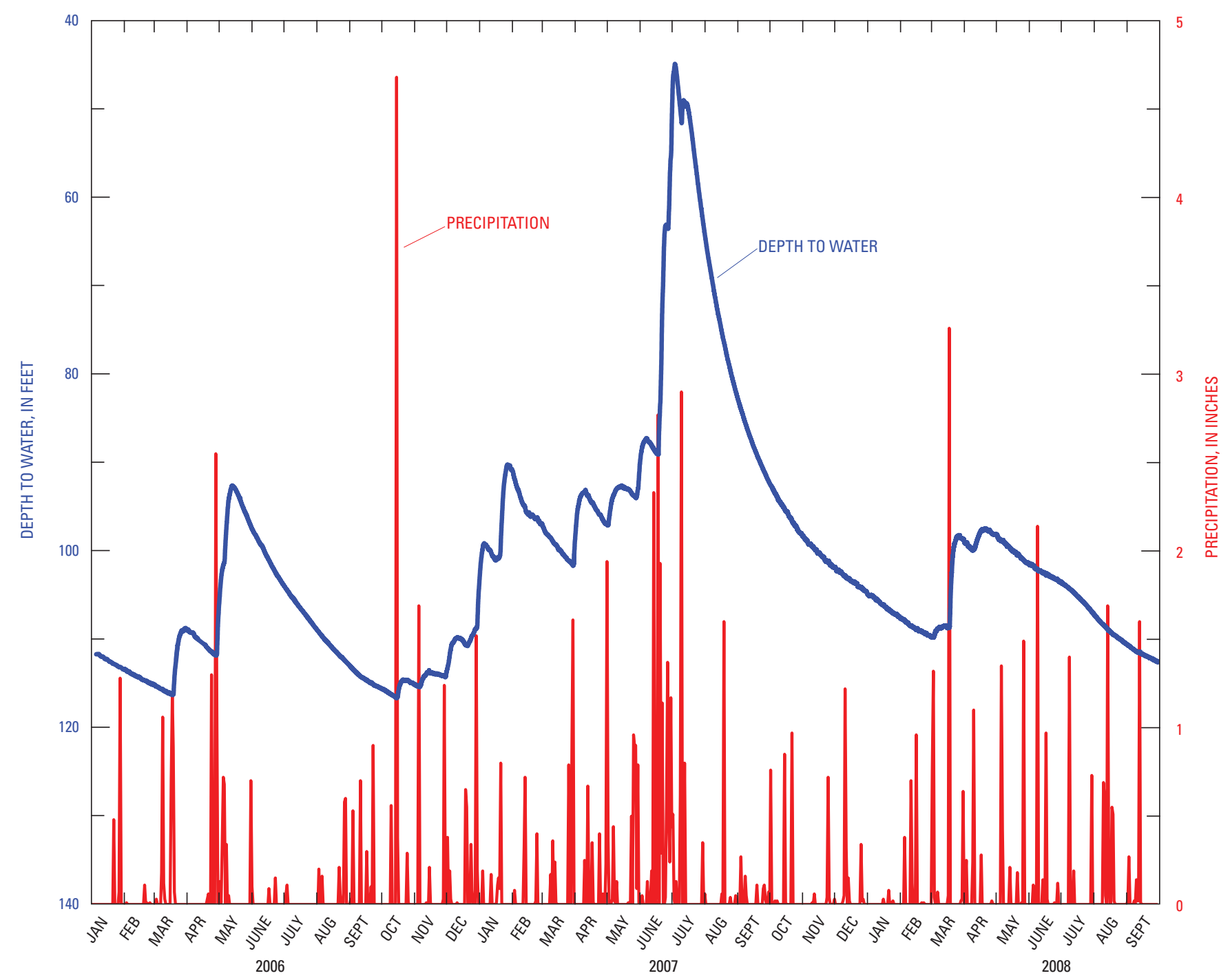

Figure 17. Precipitation and groundwater level at the Fittstown Mesonet station, south-central Oklahoma (data from Oklahoma Mesonet, 2009; location of station shown on fig. 2).

at any point reflects (but does not exactly equal) the height to which a column of water will rise in a tightly cased well. A potentiometric-surface map is constructed by contouring measurements of static head in wells. Where most of the flow in an aquifer is horizontal, a potentiometric-surface map can be used to infer the direction of groundwater flow. The potentiometric surface, in an unconfined aquifer, is the water table that is defined by the upper limit of the zone of saturation.

Potentiometric-surface maps were constructed for all or parts of the Arbuckle-Simpson aquifer in the past. Fairchild and others (1990) produced a potentiometric-surface map of the entire Arbuckle-Simpson aquifer. However, data used to produce that map had several limitations: (1) the data were collected during the winters of 1976-7 and 1977-8 and, therefore, do not represent a synoptic measurement; and (2) steel tapes measured depth to water from the land surface to the nearest $0.01 \mathrm{ft}$, but the altitude of the land surface (National Geodetic Vertical Datum of 1929) at the data-collection wells were determined from 7.5-minute, 1:24,000-scale topographic maps with contour intervals of $10 \mathrm{ft}$. The vertical accuracy of the U.S. National Map Accuracy Standards (U.S. Geological Survey, 1999) requires that the elevation of 90 percent of all points tested must be correct within half of the contour interval. Therefore, scaling elevations from topographic maps introduced an error of about $5 \mathrm{ft}$, assuming that the points were plotted correctly on the topographic maps. Fairchild and others (1990) acknowledge that data were sparse in the western Arbuckle-Simpson aquifer and, therefore, part of the map could be considered to be incomplete.

The USGS and the U.S. Environmental Protection Agency jointly measured water levels in wells completed in the eastern Arbuckle-Simpson aquifer in August 1995 
(http://nwis.waterdata.usgs.gov/ok/nwis/gwlevels). A goal of that effort was to collect a synoptic measurement during the shortest possible span of time. All water-level measurements were made from August 7 to August 16, 1995. The landsurface elevation at each well was determined from 1:24,000 topographic maps so that the vertical accuracy of these data is considered to be $5 \mathrm{ft}$. A potentiometric-surface map prepared from these data is shown in figure 18. Figure 18 includes head measurements determined from the elevations of springs and streams, but does not include head measurements in flowing wells or wells that were pumping at the time of the measurement.

Water levels in about 90 wells completed in the eastern Arbuckle-Simpson aquifer were measured quarterly during 2005 and 2006 (8 synoptic measurements) as part of this study. Each well location was determined by using a differentially corrected Global Positioning System receiver with a vertical accuracy of about $1.5 \mathrm{ft}$. Two of the potentiometric surfaces, calculated from synoptic measurements in June 2006 and September 2006, are shown in figure 19 and figure 20.

Some features are common to all of the potentiometric surfaces in the eastern Arbuckle-Simpson aquifer, regardless of the time the measurements were made. The potentiometric surface in the eastern Arbuckle-Simpson aquifer generally slopes from a topographic high, at about $\mathrm{N} 34^{\circ} 35^{\prime}$ latitude, W96 $6^{\circ} 50^{\prime}$ longitude, to the southeast, indicating that regional groundwater flow is predominantly toward the southeast (although some groundwater flows to the west and southwest), where groundwater discharges to streams and springs at the boundary of the aquifer. The hydraulic gradient in the Simpson Group is larger than the gradient in the Arbuckle Group. A persistent high in the potentiometric surface in the Simpson Group is at about $\mathrm{N} 34^{\circ} 30^{\prime}$ latitude, W96 $35^{\prime}$ longitude (NAD 83).

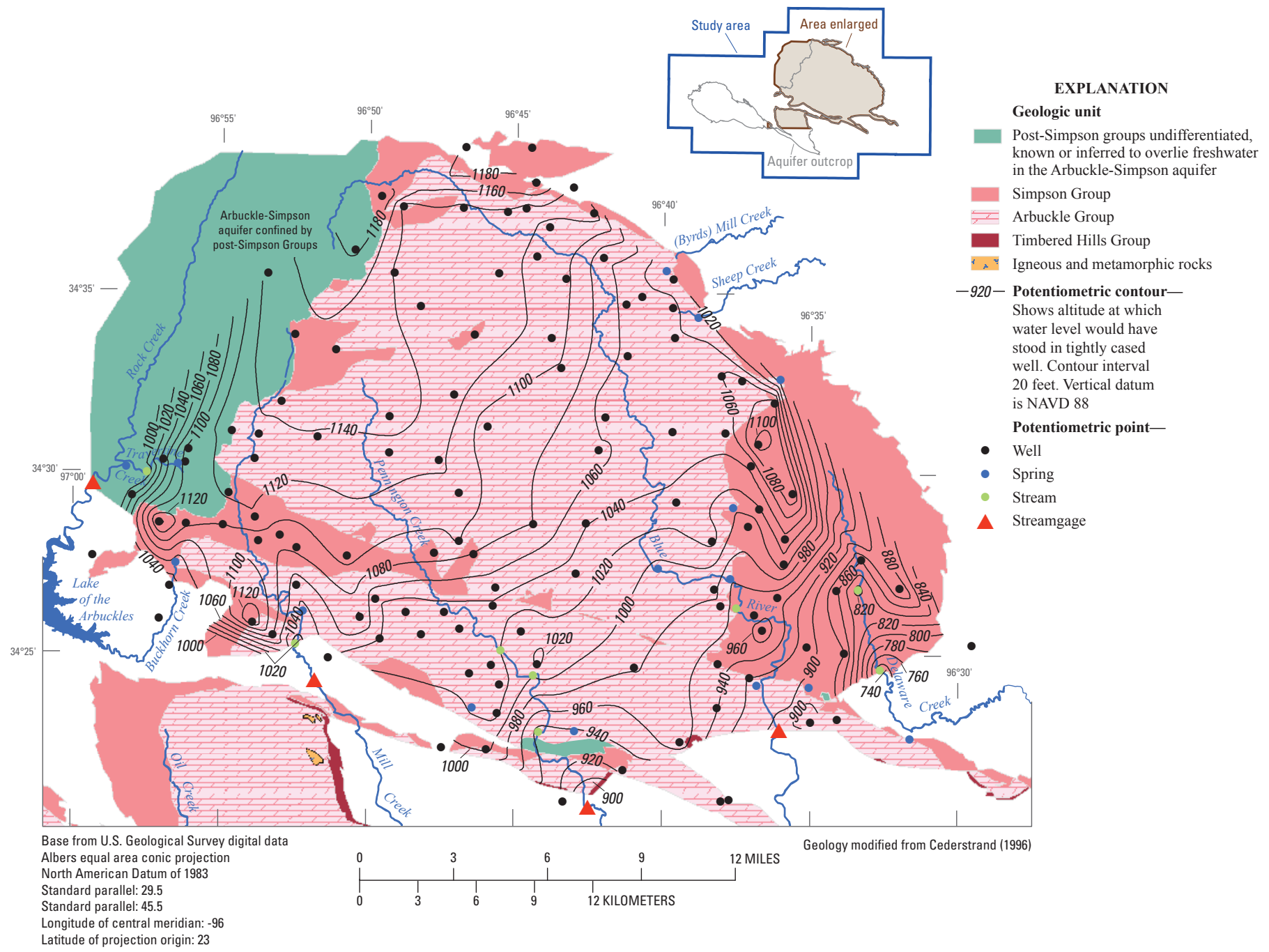

Figure 18. Potentiometric surface in the eastern Arbuckle-Simpson aquifer, south-central Oklahoma, August 1995. 


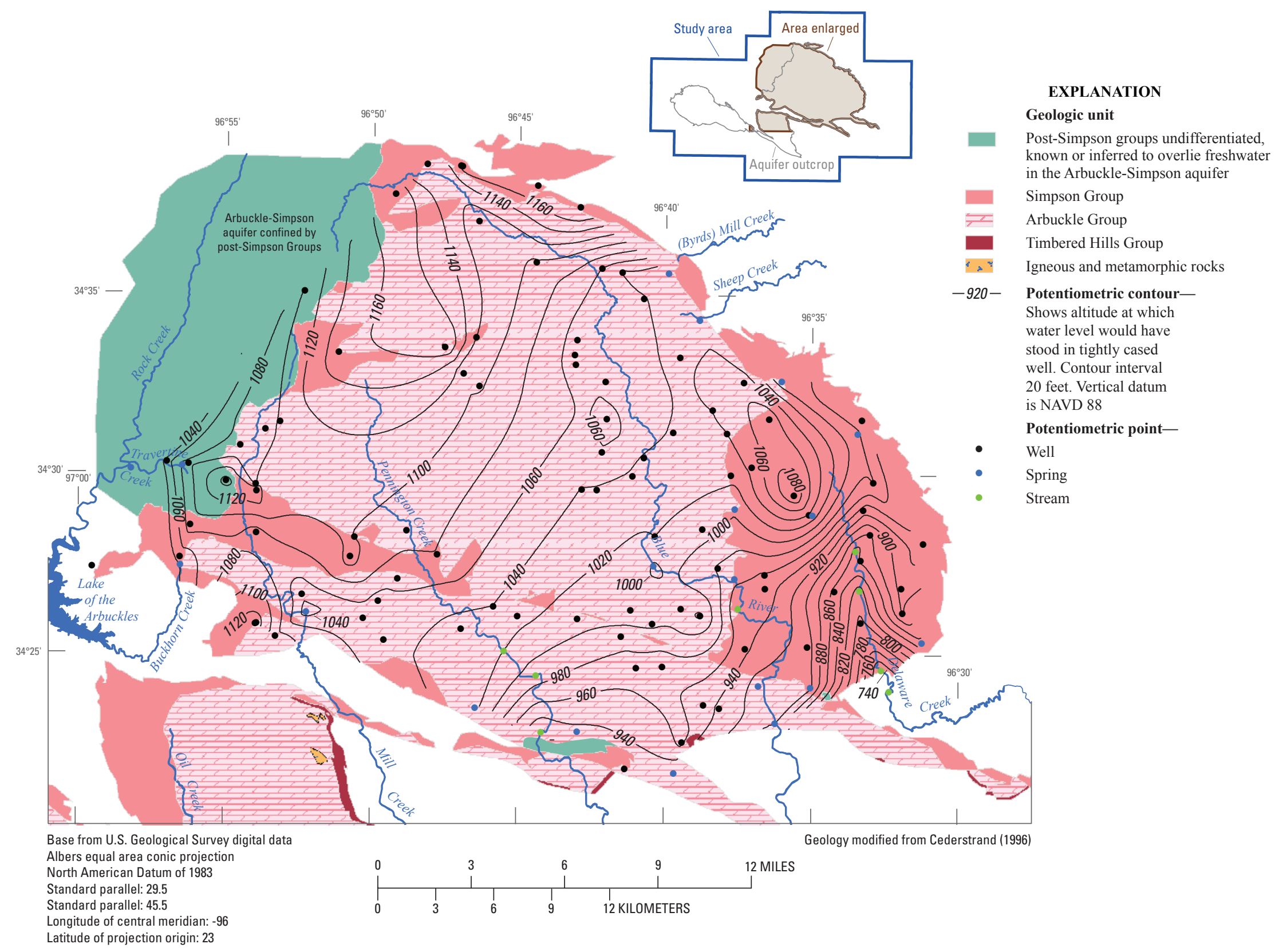

Figure 19. Potentiometric surface in the eastern Arbuckle-Simpson aquifer, south-central Oklahoma, June 2006. 


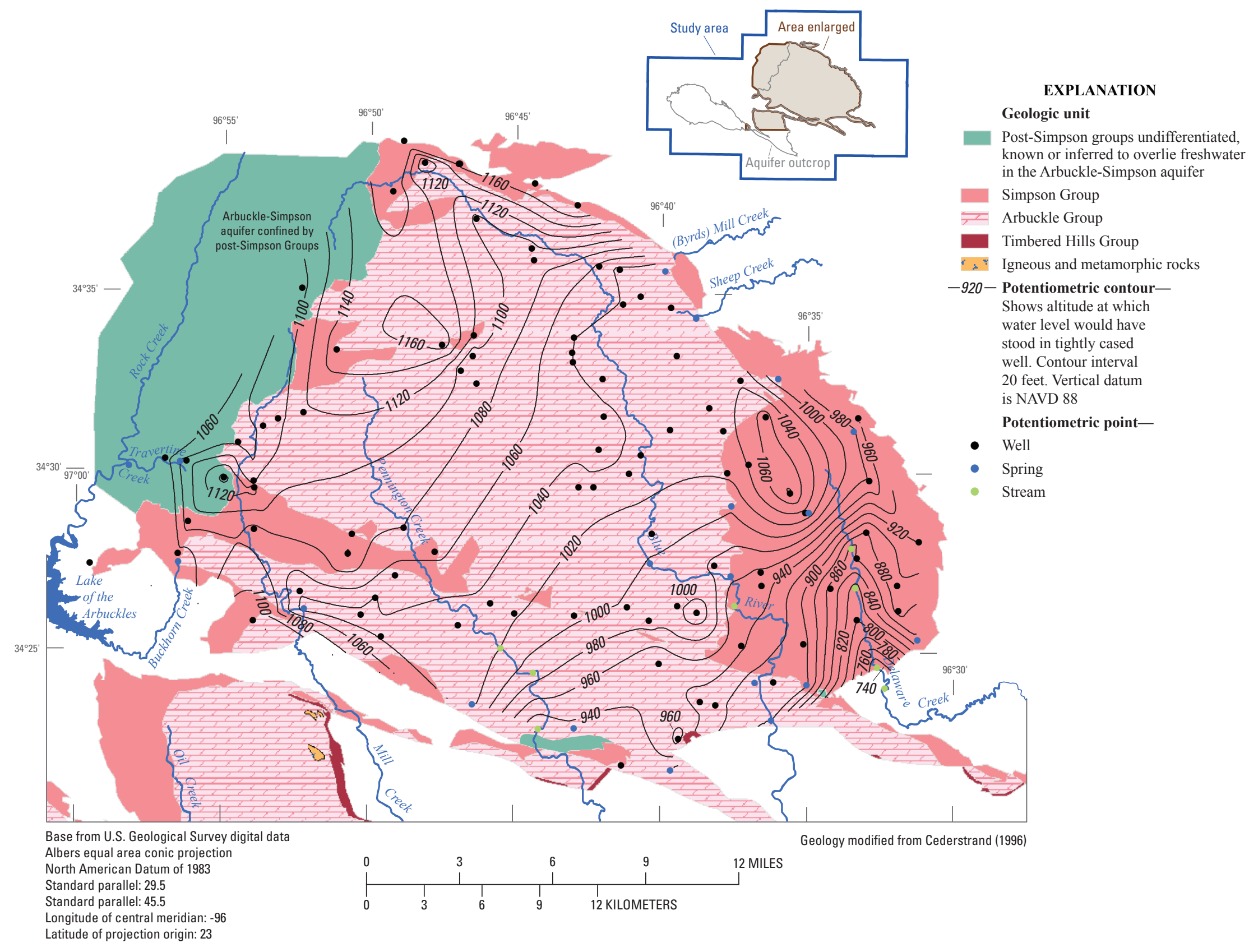




\section{Subsurface Watersheds}

A subsurface watershed can be defined as a geographic area in the subsurface that contributes flowing groundwater to a specific point. The area and boundaries of a subsurface watershed can, and commonly will, deviate to some degree from the surface watershed. The same depth-to-water and wellhead elevations used to construct the potentiometricsurface maps described in the Potentiometric Surfaces section of this report are the data used for delineating the subsurface watersheds. Multiple potentiometric-surface datasets were utilized in ArcMap Spatial Analyst (Environmental Systems Research Institute, 2001) to delineate the subsurface watersheds.

Subsurface watersheds were delineated on seven primary discharge areas on the eastern Arbuckle-Simpson aquifer, which include Blue River, Byrds Mill Spring, Delaware Creek,
Mill Creek, Pennington Creek, Sheep Creek, and Rock Creek (fig. 21). Five of the subsurface watersheds were delineated to streamgages, and two subsurface watersheds (Delaware Creek and Sheep Creek) were delineated to the intersection of the stream with the boundary of the Arbuckle-Simpson aquifer outcrop. For comparison, surface watersheds are shown in figure 22 and were delineated by using StreamStats (Koltun and others, 2006), a USGS geographic information system program that can delineate a drainage basin at any point along a stream.

The delineated areas of the surface and subsurface watersheds are listed in table 8 . Subsurface watersheds are delineated with few water-level measurements, whereas the surface watersheds are delineated with many points (DEMs). This method causes ambiguities in the subsurface watershed delineation, and as a result some areas for subsurface watersheds are expressed as ranges.

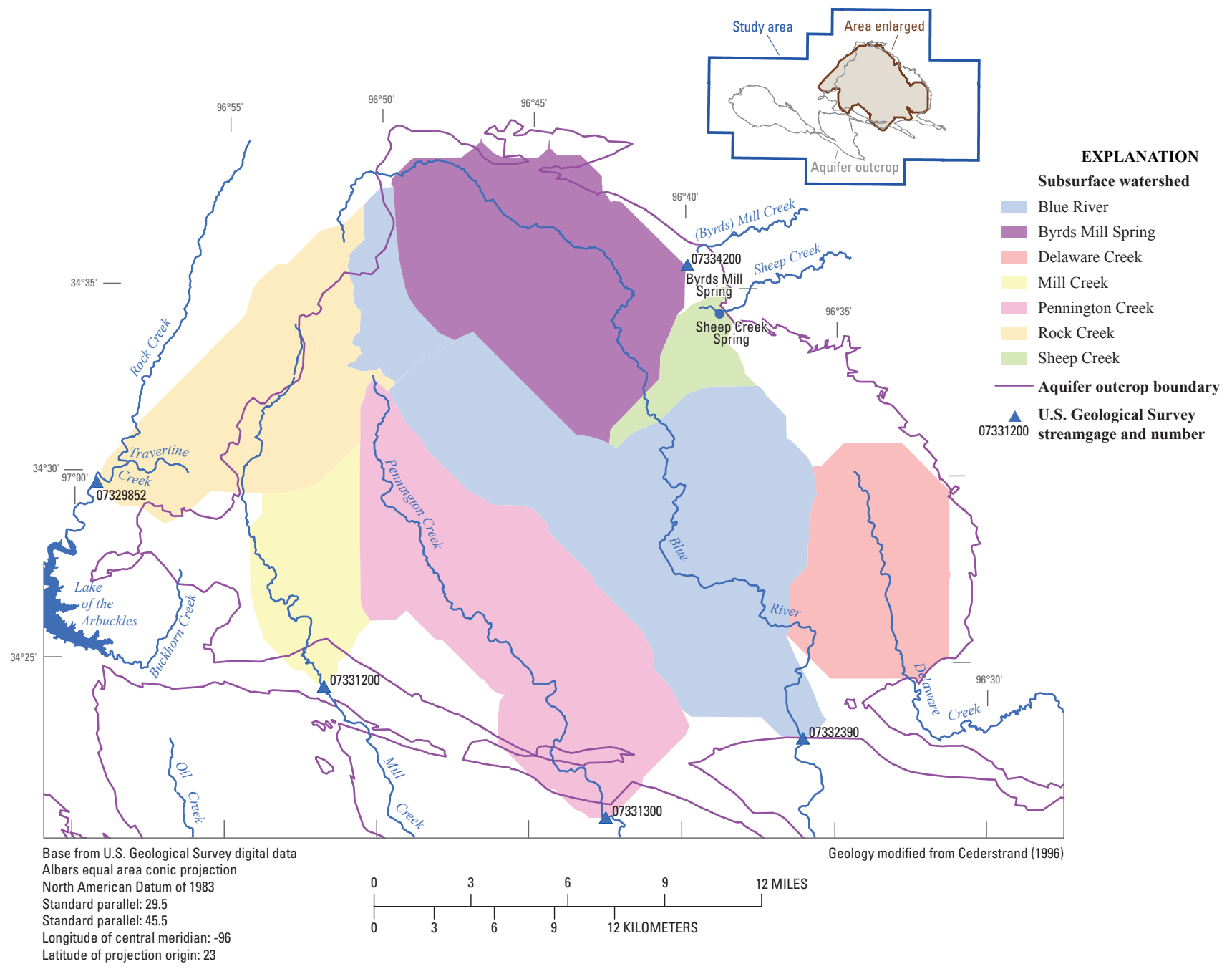

Figure 21. Subsurface watersheds in the eastern Arbuckle-Simpson aquifer, south-central Oklahoma, based on synoptic water-level measurements. 


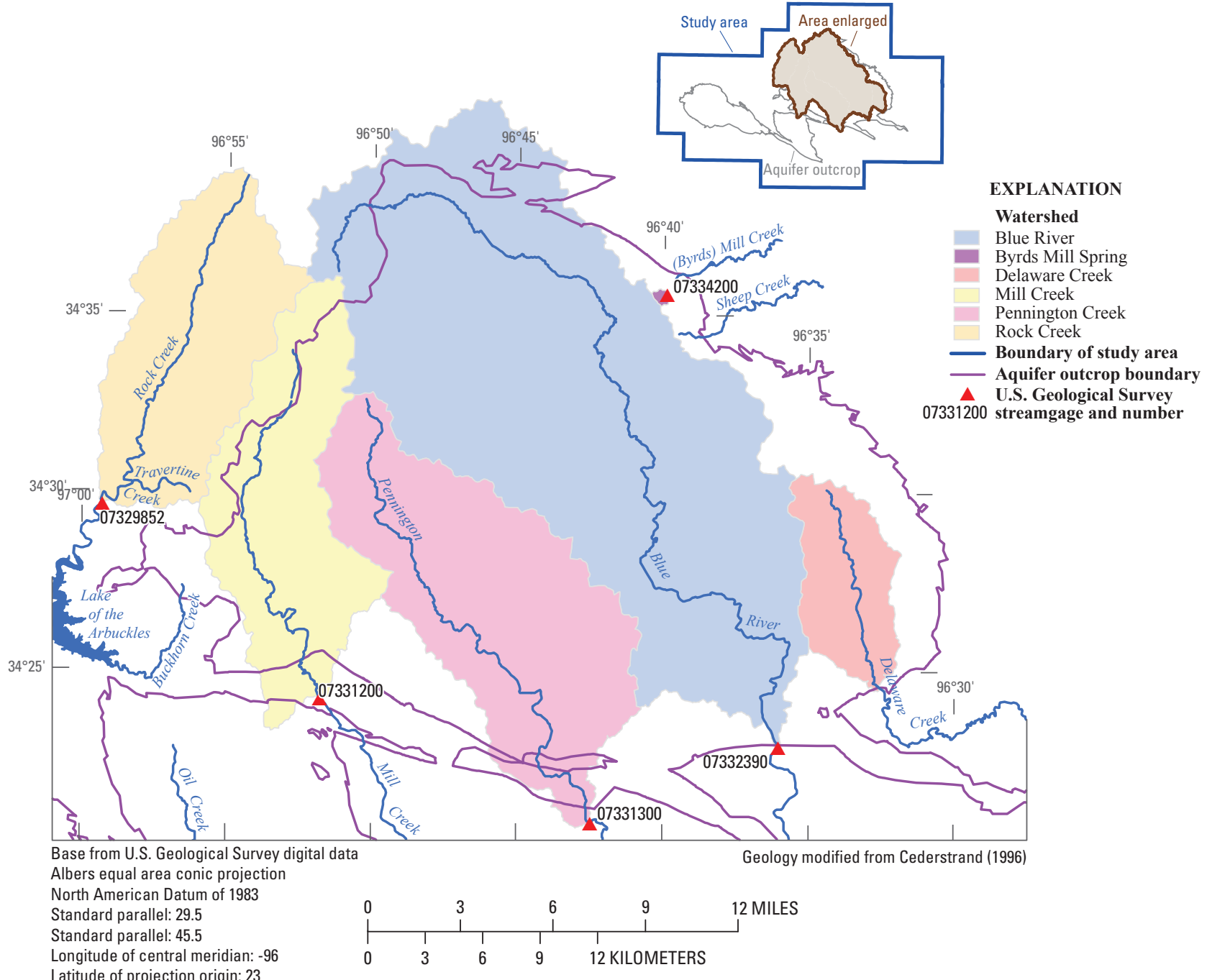

Figure 22. Surface watersheds in the eastern Arbuckle-Simpson aquifer, south-central Oklahoma.

Table 8. Areas of surface and subsurface watersheds for selected streams and springs on the eastern Arbuckle-Simpson aquifer, south-central Oklahoma.

$\left[*\right.$, area ambiguous because of low spatial resolution of point data in part of the watershed; ${ }^{+}$, watershed delineated to the point where the stream flows off the outcrop; >, greater than; ND, not determined]

\begin{tabular}{lccc}
\hline \multicolumn{1}{c}{ Stream } & Delineation point & $\begin{array}{c}\text { Surface watershed area } \\
\text { (square miles) }\end{array}$ & $\begin{array}{c}\text { Subsurface watershed area } \\
\text { (square miles) }\end{array}$ \\
\hline Blue River & Streamgage & 162.41 & $79.02-88.41 *$ \\
Byrds Mill Spring & Streamgage & 0.20 & 54.19 \\
Delaware Creek & Outcrop+ & 17.00 & 30.74 \\
Mill Creek & Streamgage & 46.74 & 18.72 \\
Pennington Creek & Streamgage & 66.20 & 61.91 \\
Rock Creek & Streamgage & 44.10 & $>32.74^{*}$ \\
Sheep Creek & Outcrop+ & ND & 7.75 \\
\hline
\end{tabular}


The largest difference between the surface and subsurface watersheds is at the northern extent of the eastern ArbuckleSimpson aquifer, where the Blue River surface watershed was delineated into the Blue River, Byrds Mill Spring, and Sheep Creek subsurface watersheds. Most of the upper Blue River surface watershed is in the Byrds Mill Spring subsurface watershed; the Sheep Creek subsurface watershed also is largely in the upper Blue River surface watershed. The Byrds Mill Spring surface watershed is only $0.2 \mathrm{mi}^{2}$, which is not compatible with an average discharge of $18.5 \mathrm{ft}^{3} / \mathrm{s}$ from the spring. Dividing the average discharge of $18.5 \mathrm{ft}^{3} / \mathrm{s}$ by the $0.2-\mathrm{mi}^{2}$ surface watershed equates to a recharge rate of over 1,200 inches per year, far exceeding the average annual precipitation, whereas dividing $18.5 \mathrm{ft}^{3} / \mathrm{s}$ by the $54.19 \mathrm{mi}^{2}$ for the Byrds Mill Spring subsurface watershed equates to a recharge of 4.6 inches per year, comparable to the 4.7 inches per year average recharge rate described by Fairchild and others (1990).

The Rock Creek subsurface watershed deviates from the surface watershed by encompassing more area to the east, into the Mill Creek surface watershed, and less area to the west, although the subsurface watershed for Rock Creek could not be delineated to the west because of a lack of groundwater data. This difference in the extent of the surface and subsurface watersheds is compatible with the geochemistry of the water samples from Antelope Spring and Vendome Well in CNRA; these water samples indicated that most of the water discharging from those features originated as recharge from the area where the Arbuckle Group is at the land surface (Christenson and others, 2009). The Rock Creek subsurface watershed, which includes Antelope Spring and Vendome Well, extends into the area where the Arbuckle Group is at the land surface but the Rock Creek surface watershed is not.

\section{Recharge}

Recharge is the process by which water enters an aquifer and becomes part of groundwater-flow systems. Although recharge can be the result of many different processes, the dominant recharge process for the Arbuckle-Simpson aquifer is infiltration of precipitation through the soil zone. Precipitation falling on the land surface infiltrates through soil to the unsaturated zone. Some of the water in that zone is evaporated or transpired by plants back to the atmosphere and some continues moving downward through the unsaturated zone to recharge groundwater in the saturated zone. The amount of precipitation that infiltrates into soil and passes through an unsaturated zone to recharge an aquifer depends on many factors, such as the amount of water stored in the unsaturated zone, the slope of the land surface, the type of rocks and soils that form an aquifer, the type of vegetation and land use overlying the aquifer, and the intensity, season, and duration of precipitation. For example, equal amounts of precipitation falling on sandy or clay soils tend to produce more recharge on sandy soil than on clay soil because more precipitation infiltrates into sandy soil than clay soil. Another example is that equal amounts of precipitation falling on an aquifer in winter and summer will tend to produce more recharge in winter than in summer because evapotranspiration of water in the soil zone is less in the winter.

Recharge from infiltration of precipitation is difficult to quantify because the recharge rate can vary greatly over short spatial and temporal scales, and is difficult to measure directly. Fairchild and others (1990) estimated an average recharge rate to the Arbuckle-Simpson aquifer of about 4.7 inches per year.

Another potential source of recharge to the ArbuckleSimpson aquifer was considered to be recharge from stream loss. Recharge by stream loss happens where streams with watersheds upstream from an aquifer flow onto the aquifer outcrop and flow downward into the aquifer through sinkholes or fractures. Recharge by stream loss is known to happen in other aquifers, such as the Edwards aquifer in Texas (Woodruff, 1977). All the streams that flow across the Arbuckle-Simpson aquifer originate in the aquifer boundary, except for the Washita River. The Washita River flows across the aquifer, and a small part of the drainage area of that river is on the outcrop of the Arbuckle-Simpson aquifer. As described in the Streamflow section of this report, water-level measurements near the Washita River in the late 1970s by Fairchild and others (1990) indicated that the potentiometric surface sloped toward the Washita River, and, therefore, groundwater was discharging to the river and the river did not recharge the aquifer. Therefore, recharge by stream loss has been determined to be negligible in the Arbuckle-Simpson aquifer.

The primary method used to determine recharge for the Arbuckle-Simpson aquifer for this study was a recessioncurve-displacement method, originally developed by Rorabaugh (1964). That method is based on the measurement of the change in the total potential groundwater discharge (base flow) as estimated at a critical time after the peak by extrapolation from the prepeak and the postpeak recession periods (Rutledge, 1998). Recharge from each precipitation event is assumed to be the difference between the groundwater discharge and the groundwater discharge that would have happened at the same time in the absence of the recharge event, based on extrapolation of the streamflow hydrograph prior to the recharge event. Recharge commonly is divided by the area of the drainage basin and expressed as a rate, for example, inches of recharge per year. The areas of the subsurface drainage basins (see the Subsurface Watersheds section of this report) were used as the drainage basin area for the analysis. A series of computer programs by Rutledge (1998) were used to analyze daily stream discharge data for streamgages on the Arbuckle-Simpson aquifer. The methods for computing recharge described in Rutledge (1998) are intended for analysis of flow systems that (1) are driven by areally diffuse recharge events; (2) have a stream as a sink (discharge boundary) for the groundwater-flow system; (3) are not dominated by leakage to or from regional-flow systems, snowmelt runoff, recharge from losing streams, or groundwater withdrawals; and (4) have drainage basins with 
areas greater than 1 and less than $500 \mathrm{mi}^{2}$. These conditions are met for some of the streams draining the ArbuckleSimpson aquifer but not for all streams, and, therefore, the discharge data were not analyzed for all streamgages.

The configuration of some of the streams draining the Arbuckle-Simpson aquifer relative to the aquifer geometry is well suited for determining recharge by recession-curvedisplacement methods. Groundwater flowing through the Arbuckle-Simpson aquifer is forced to discharge at the aquifer boundary where the more hydraulically conductive Arbuckle-Timbered Hills hydrostratigraphic unit is bounded by less conductive basement rocks and post-Simpson hydrostratigraphic units. Three streamgages were installed at the beginning of the Arbuckle-Simpson Hydrology Study for several purposes, one of which was to calculate recharge. These streamgages are Blue River near Connerville (07332390), Pennington Creek near Reagan (07331300), and Honey Creek below Turner Falls near Davis (07329780) (fig. 14). These streamgages were constructed at locations that were optimal for recharge calculations. The gages were placed at the point where the stream flows off the aquifer outcrop and on to geologic units of lower permeability, and, therefore, the base flow discharging to the stream was exclusively from the Arbuckle-Simpson aquifer and the watershed contributing to the stream upstream from the streamgage included the maximum possible area of the aquifer.

Other streamgages are in the study area, including Antelope Spring at Sulphur, Oklahoma (07329849), Byrds Mill Spring near Fittstown, Oklahoma (07334200), Mill Creek near Mill Creek, Oklahoma (07331200), Pennington Creek east of Mill Creek, Oklahoma (07331295), Rock Creek at Sulphur, Oklahoma (07329852), Wildhorse Creek near Hoover, Oklahoma (07329700), and Washita River near Dickson, Oklahoma (07331000). However, none of these gages was optimally located to calculate recharge by the hydrograph-displacement method, for the following reasons:

1. Streamflow data from Antelope Spring at Sulphur, Oklahoma (07329849), were not analyzed because Antelope Spring is on the confined part of the Arbuckle-Simpson aquifer and the surface water drainage basin is unlikely to be the same as the area contributing groundwater to the spring; sufficient head observations were not available to determine the area of the subsurface drainage basin. Additionally, Antelope Spring is near the well field for the City of Sulphur and flow from the spring may be affected by withdrawals from the wells.

2. Streamflow data from Byrds Mill Spring near Fittstown, Oklahoma (07334200), were not analyzed because discharge from the spring flows into several pipes and to a weir, and the total spring discharge is determined by combining the measured flow from the pipes (by flow meters) and the weir (by measuring stage and by using a stage-discharge relation); the combination of measurements probably has a larger error than a similar measurement at a traditional streamgage.

3. Streamflow data from Mill Creek near Mill Creek, Oklahoma (07331200), were not analyzed because surface water is withdrawn directly from the stream upstream from the streamgage.

4. Streamflow data from Pennington Creek east of Mill Creek, Oklahoma (07331295), were not analyzed because the streamgage is not at the point where the stream flows off the aquifer, as was Pennington Creek near Reagan, Oklahoma (07331300), and the streamflow record is not as long as the record for Pennington Creek near Reagan.

5. Streamflow data from Rock Creek at Sulphur, Oklahoma (07329852), were not analyzed because of insufficient potentiometric data to accurately determine the subsurface drainage area.

6. Streamflow data from Wildhorse Creek near Hoover, Oklahoma (07329700), were not analyzed because most of the drainage area is not on the Arbuckle-Simpson aquifer.

7. Streamflow data from Washita River near Dickson, Oklahoma (07331000), were not analyzed because most of the drainage area is not on the ArbuckleSimpson aquifer.

The computer programs used to compute recharge (Rutledge, 1998) require the following data as input: (1) daily streamflow data for streamgages from the USGS National Water Information System Web site (for streams in Oklahoma, http://waterdata.usgs.gov/ok/nwis), (2) the median recession index, and (3) the area of the watershed (either the subsurface or surface watershed) upstream from the streamgage. The recession index is the time required for groundwater discharge to decline through one log cycle of flow; the median recession index is the median value for the best-fit equation for the rate of recession for the gaged stream as a function of the logarithm of flow (for a complete description, see Rutledge, 1998). The computer program RECESS (Rutledge, 1998) was used to determine the median recession index for each streamgage for this study. The area of the watershed upstream from the streamgage normally is determined from the topography of the watershed, either manually or by using a geographical information system (GIS). As described in the Subsurface Watersheds section of this report, potentiometricsurface maps show that the subsurface watersheds in the eastern Arbuckle-Simpson aquifer do not precisely coincide with the surface watersheds. The area of the subsurface watershed was used as input to the RORA (the term "RORA" is a name and not an acronym) program (Rutledge, 1998) because the subsurface watershed is the area contributing groundwater to the stream, and the recession part of the stream hydrograph represents groundwater discharge. 
The RORA program computes recharge for individual recharge events and calculates quarterly and annual recharge totals for each streamgage. The median recession index, subsurface watershed area, and quarterly and annual recharge rates for the streamgages at Blue River near Connerville, Oklahoma (07332390), Honey Creek below Turner Falls near Davis, Oklahoma (07329780), and Pennington Creek near Reagan, Oklahoma (07331300), are shown in table 9.

Several observations can be made about recharge to the Arbuckle-Simpson aquifer as shown in table 9. Recharge varies spatially and temporally. Spatial variation is seen by comparing recharge between Blue River, Honey Creek, and Pennington Creek for any given quarter or year; the differences between Blue River and Pennington Creek are particularly striking because those drainage basins are adjacent to each other. Temporal variation is seen by calculating recharge at a streamgage over time. Recharge tends to be highest in the January-March and April-June quarters and lowest during the July-September quarter.

Recharge for every year of data shown in table 9 is greater than the 4.7 inches per year average recharge calculated by Fairchild and others (1990). This difference is thought to be primarily caused by the difference in the surface watershed area for the Blue River near Connerville, Oklahoma, streamgage $\left(162.41 \mathrm{mi}^{2}\right)$ used by Fairchild and others (1990) and the subsurface watershed area used for this study $\left(88.41 \mathrm{mi}^{2}\right)$.

Recharge calculated by using hydrograph-displacement methods apply only to the area of the watershed upstream from the streamgage. Recharge rates calculated for the entire eastern Arbuckle-Simpson aquifer are presented in the Simulation of Groundwater Flow section of this report.

Recharge can be estimated by dividing the base-flow discharge of a stream by the contributing drainage area (that is, the subsurface or surface watershed) above the measurement site. However, this method was thought to be inferior to the hydrograph-displacement method for this study because dividing the base flow by the contributing area assumes that recharge is constant.

\section{Hydraulic Properties}

The term "hydraulic properties" is used in the report to describe the properties of the Arbuckle-Simpson aquifer that govern groundwater storage and flow in the aquifer. Hydraulic properties can be described in several ways, depending on the application. For this report, the storage of water in a hydrostratigraphic unit is described in terms of storage coefficient, specific storage, specific yield, and porosity; and the transmissive characteristic of a hydrostratigraphic unit is described in terms of the transmissivity, which is the product of the hydraulic conductivity and thickness of an aquifer.

The storage coefficient of a hydrostratigraphic unit is the volume of water an aquifer releases from or takes into storage per unit surface area of the aquifer per unit change in head (Lohman, 1972), and is dimensionless. The specific storage is the amount of water that a hydrostratigraphic unit releases from storage, per unit mass or volume of aquifer, per unit change in hydraulic head; specific storage is the storage coefficient divided by the thickness of the aquifer. Water is released from storage in a confined aquifer by the elastic expansion of water and the compaction of the aquifer matrix as head is lowered. The storage coefficient in an unconfined aquifer is virtually the same as the specific yield, which is the ratio of the volume of water which the porous medium after being saturated will yield by gravity to the volume of the porous medium (Lohman and others, 1972). The storage coefficient of most confined aquifers ranges from about $10^{-5}$ to $10^{-3}$, which is largely a measure of the amount of water released from storage because of the compressibility of the rock matrix as hydraulic head is decreased; the specific yield of most unconfined aquifers ranges from about 0.1 to about 0.3 , and may be thought of as the interconnected porosity, which is dewatered as water levels in the aquifer decline (Lohman, 1972). All determinations of storage coefficient by Fairchild and others (1990) and by this study were less than 0.1, even in the parts of the aquifer that should be unconfined because the Arbuckle Group is at the land surface and not overlain by a confining layer. The storage coefficient may be relatively small $(<0.1)$ in the unconfined parts of the aquifer because the carbonate matrix of the Arbuckle Group has little void space, or the aquifer may be confined at the locations where storage coefficient was determined. Because the determination of whether groundwater in the Arbuckle-Simpson aquifer is confined or unconfined is not always possible, aquifer-storage properties are reported as storage coefficient and not as specific yield.

Porosity is the ratio of void space to the total volume of a solid and is expressed as a decimal fraction or percentage. Porosity in carbonate rocks, such as those of the Arbuckle Group, can be formed during deposition or diagenesis, by faulting or fracturing, or by dissolution.

Hydraulic conductivity is the volume of water at the existing kinematic viscosity that will move in unit time under a unit hydraulic gradient through a unit area measured at right angles to the direction of flow (Lohman, 1972). Transmissivity is the rate at which water of the prevailing kinematic viscosity is transmitted through a unit width of the aquifer under a unit hydraulic gradient (Lohman, 1972). Transmissivity is the product of the hydraulic conductivity and the saturated thickness of an aquifer; if the aquifer is confined, the saturated thickness is the thickness of the aquifer between the upper and lower confining layers; and if the aquifer is unconfined, the saturated thickness is the distance between the water table and the base of the aquifer.

The hydraulic properties of hydrostratigraphic units can change by many orders of magnitude over short distances. For example, the hydraulic conductivity of shale might be on the order of $10^{-12} \mathrm{ft}$ per second ( $\mathrm{ft} / \mathrm{s}$ ) and the hydraulic conductivity in sand that is in contact with that shale on the order of $10^{-1}$ $\mathrm{ft} / \mathrm{s}$, representing a contrast of about 11 orders of magnitude. Therefore, values of hydraulic conductivity are expressed as ranges or distributions. 
Table 9. Quarterly recharge calculated for watersheds upstream from select streamgages on the Arbuckle-Simpson aquifer, south-central Oklahoma.

\begin{tabular}{|c|c|c|c|c|c|c|c|c|c|}
\hline \multirow[b]{3}{*}{ Station name } & \multirow[b]{3}{*}{ Station number } & \multirow[b]{3}{*}{$\begin{array}{l}\text { Watershed } \\
\text { area (square } \\
\text { miles) }\end{array}$} & \multirow{3}{*}{$\begin{array}{c}\text { Median } \\
\text { recession index } \\
\text { (days per log } \\
\text { cycle) }\end{array}$} & \multirow[b]{3}{*}{ Water year } & \multicolumn{5}{|c|}{ Recharge (inches) } \\
\hline & & & & & \multicolumn{5}{|c|}{ Quarter } \\
\hline & & & & & $\begin{array}{l}\text { October- } \\
\text { December }\end{array}$ & January-March & April-June & $\begin{array}{c}\text { July- } \\
\text { September }\end{array}$ & Yearly total \\
\hline \multirow{9}{*}{$\begin{array}{l}\text { Blue River near } \\
\text { Connerville }\end{array}$} & 07332390 & $88.4^{1}$ & 150.86 & 1977 & 1.42 & 4.04 & 2.09 & 1.38 & 8.93 \\
\hline & & & & 1978 & 1.26 & 2.36 & 3.24 & 1.31 & 8.17 \\
\hline & & & & 1979 & 1.28 & 2.29 & 2.94 & 1.16 & 7.67 \\
\hline & & & & 2004 & 2.13 & 2.32 & 1.31 & 1.54 & 7.30 \\
\hline & & & & 2005 & 5.13 & 6.13 & 1.19 & 1.39 & 13.84 \\
\hline & & & & 2006 & 1.48 & 2.19 & 2.11 & 0.76 & 6.54 \\
\hline & & & & $2007^{3}$ & 1.96 & 3.32 & 16.04 & 0.01 & 21.33 \\
\hline & & & & 2008 & 1.77 & 2.90 & 2.21 & 1.09 & 7.97 \\
\hline & & & & Average $^{3}$ & 2.05 & 3.19 & 3.89 & 1.08 & 10.22 \\
\hline \multirow{5}{*}{$\begin{array}{l}\text { Honey Creek } \\
\text { below Turner } \\
\text { Falls near } \\
\text { Davis }\end{array}$} & 07329780 & $16.4^{2}$ & 42.05 & 2005 & 3.86 & 4.71 & 1.16 & 2.83 & 12.56 \\
\hline & & & & 2006 & 1.08 & 2.57 & 2.85 & 0.14 & 6.64 \\
\hline & & & & $2007^{3}$ & 3.22 & 4.36 & 8.61 & 2.88 & 19.07 \\
\hline & & & & 2008 & 1.14 & 3.23 & 1.82 & 0.38 & 6.57 \\
\hline & & & & Average $^{3}$ & 2.33 & 3.72 & 3.61 & 1.56 & 11.21 \\
\hline \multirow{6}{*}{$\begin{array}{l}\text { Pennington } \\
\text { Creek near } \\
\text { Reagan }\end{array}$} & 07331300 & $61.9^{1}$ & 94.06 & 2004 & 0.78 & 2.03 & 0.90 & 1.35 & 5.06 \\
\hline & & & & 2005 & 3.51 & 5.12 & 1.22 & 1.01 & 10.86 \\
\hline & & & & 2006 & 1.03 & 1.18 & 1.98 & 0.64 & 4.83 \\
\hline & & & & $2007^{3}$ & 1.76 & 2.87 & 11.27 & 0.51 & 16.41 \\
\hline & & & & 2008 & 0.92 & 1.91 & 1.35 & 0.67 & 4.85 \\
\hline & & & & Average $^{3}$ & 1.60 & 2.62 & 3.34 & 0.84 & 8.40 \\
\hline
\end{tabular}

${ }^{1}$ Watershed area based on subsurface watershed

${ }^{2}$ Watershed area based on surface watershed.

${ }^{3}$ Computation ambiguous because of large-scale flooding in 2007. 
Many methods can be used to determine hydraulic properties of hydrostratigraphic units. Some methods, such as measurements of cores, provide determinations that are applicable to scales on the order of inches. Aquifer tests provide descriptions that apply at the scale of feet to hundreds of feet, and other techniques, such as the regional methods described in this report, provide descriptions of hydraulic properties that are applicable on the scale of miles. One of the objectives of this study was to evaluate aquifer-scale effects of changes in streamflow associated with increases in groundwater withdrawals, and, therefore, methods appropriate for larger scales (aquifer tests and regional methods) were used to determine hydraulic properties.

\section{Aquifer Tests}

Fairchild and others (1990) describe the hydraulic properties of the Arbuckle-Simpson aquifer from information in the files of the USGS and aquifer tests done for that report. That report described specific capacities that ranged from 0.17 to 104 (gallons per minute) per foot of drawdown in wells that ranged in depth from 45 to $2,500 \mathrm{ft}$ deep (specific capacity is the rate of discharge of water from the well divided by the drawdown of the water level in the well; specific capacity is a property of the well and is related to the transmissivity of the aquifer). Fairchild and others (1990) noted that deeper wells tended to have larger specific capacities than shallower wells, and that "information from drillers and land owners suggests that the upper few hundred feet of the Arbuckle Group has a much lower permeability than the lower part." Production of water from a test well drilled as part of this study (shown as Test Well on fig. 2) increased with depth, supporting the observation in Fairchild and others (1990) that the productivity of the Arbuckle Group tends to increase with depth.

Fairchild and others (1990) also determined transmissivity in eight wells by using recovery data from a combination of single and multiwell aquifer tests. Those tests used a relatively small pump (rated at $50 \mathrm{gal} / \mathrm{min}$ ) and used steel tapes to measure water levels. Seven of the eight wells were $167 \mathrm{ft}$ deep or less, and one well was reported to be $2,403 \mathrm{ft}$ deep. Therefore, seven of eight of those transmissivity determinations were likely to be from the shallow, less productive part of the aquifer. Fairchild and others (1990) analyzed recovery data by using the non-equilibrium formula as described in Ferris and others (1962). The non-equilibrium formula is based on the following assumptions: (1) the aquifer is homogeneous and isotropic; (2) the aquifer has infinite areal extent; (3) the well penetrates and receives water from the entire thickness of the aquifer; (4) the transmissivity is constant at all times and at all places; (5) the well has an infinitesimal (reasonably small) diameter; and (6) water removed from storage is discharged instantaneously with decline in head (Ferris and others, 1962). None of the aquifer tests analyzed by Fairchild and others (1990) meet the assumptions of the non-equilibrium formula, but despite the restrictive assumptions on which the formula is based, the non-equilibrium formula has been applied to many problems of groundwater flow (Ferris and others, 1962). Fairchild and others (1990) reported that transmissivity ranged from 40 to $2,460 \mathrm{ft}$ squared per day ( $\mathrm{ft}^{2} /$ day), with the smallest transmissivity being measured from the deepest well, which is opposite of the observed increase in specific capacity with depth in the Arbuckle-Simpson aquifer described in that report.

Fairchild and others (1990) used the non-equilibrium method of Ferris and others (1962) to determine the storage coefficient by analyzing the recovery data from two observation wells near a pumping well. The three measured wells were in Johnston County, at about N34 $24^{\prime}$ latitude, W96 $48^{\prime}$ longitude (NAD 83), and were completed in the Simpson Group. The pumping well was $107 \mathrm{ft}$ deep and the observation wells were 110 and $167 \mathrm{ft}$ deep. The storage coefficient determined by Fairchild and others (1990) was $5.0 \times 10^{-5}$ for the 110 -ft-deep well and $3.7 \times 10^{-4}$ for the 167-ft-deep well.

A two-well aquifer test was done as part of this study (shown as Aquifer test site on fig. 2). The production well was $1,116 \mathrm{ft}$ deep and cased to a depth of $401 \mathrm{ft}$. The well was open (uncased) below the casing, and the well diameter below the casing was 8.75 inches. An observation well, $63 \mathrm{ft}$ from the production well, was $900 \mathrm{ft}$ deep, cased to a depth of $300 \mathrm{ft}$, and had a 22-inch-diameter open borehole below the casing. The wells were completed at the contact between the Arbuckle Group and the post-Simpson confining units; the Simpson Group was absent or very thin at this location. The productionwell pump started at 10:10 a.m. on the morning of June 8, 2006. The pump ran at a rate of about $518 \mathrm{gal} / \mathrm{min}$ for almost 24 hours and shut off at 10:08 a.m. on the morning of June 9 . A hydrograph showing the water level in the observation well is shown in figure 23 .

The aquifer test was analyzed by using the AQTESOLV software package (Hydrosolve, Inc., 2010). The hydrograph showing the trend before the test started shows that the effects of the previous pumping cycles had not fully dissipated. Therefore, only the recovery data were analyzed using the AQTESOLV program. The depths of the production and observation wells and the depths to which the wells were cased were input to the AQTESOLV program to correct for the effects of partial penetration of the aquifer. Several different analytical solutions were tried, but the best fit of the data was achieved by using the Neuman unconfined solution (Neuman, 1974). The fitted analytical solution plotted with the recovery data and derivatives, plotted in Agarwal equivalent time [a simple transformation devised by Agarwal (1980) that enables the analysis of recovery test data analysis by using the same type curves developed for drawdown data], is shown in figure 24 .

Transmissivity from the analytical solution was $12,000 \mathrm{ft}^{2} /$ day; Fairchild and others (1990) estimated an average transmissivity for the aquifer of $12,000 \mathrm{ft}^{2} /$ day. The Neuman unconfined solution does not calculate hydraulic conductivity, but based on the aquifer thickness at the test 


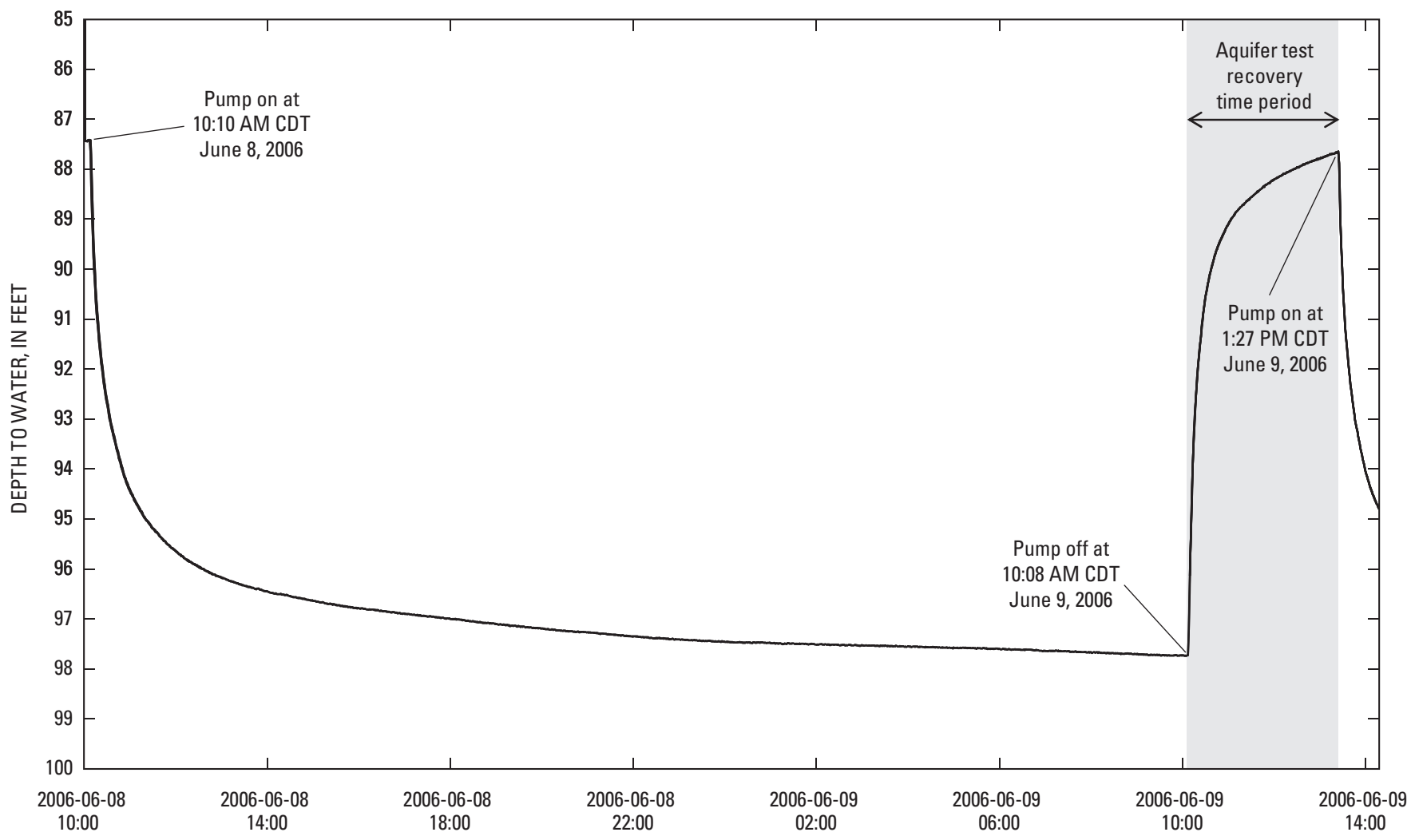

Figure 23. Water level in the observation well in Murray County, Oklahoma, during the June 8-9, 2006, aquifer test.

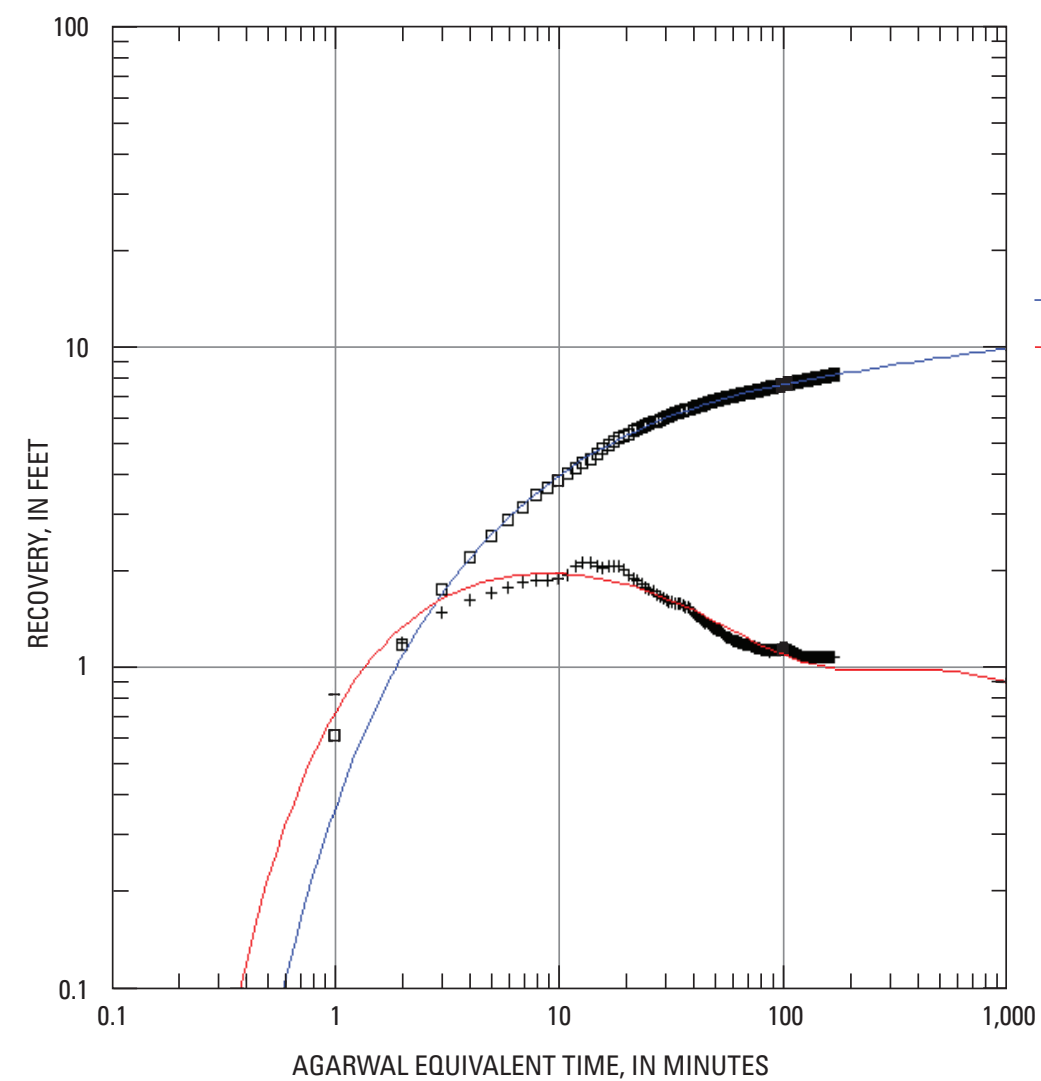

\section{EXPLANATION}

$\square$ Change in head in the observation well

+ Derivative of change in head in observation well

- Model best fit of head

- Model best fit of derivatives
Figure 24. Modeled best fit of change in head during the recovery period in the observation well during a two-well aquifer test in Murray County, Oklahoma, June 8-9, 2006. 
site of about $3,700 \mathrm{ft}$, the hydraulic conductivity is about $3.2 \mathrm{ft} /$ day $(0.98 \mathrm{~m} /$ day $)$. Although the test was not of sufficient duration to confidently determine a storage coefficient, the best fit between the analytical solution and the recovery data was achieved with a storage coefficient of 0.011 ; Fairchild and others (1990) estimated an average storage coefficient of 0.008 .

\section{Regional Methods To Determine Storage Coefficient}

The term "regional methods" is used to describe methods of analysis of hydrologic data at scales of hundreds to thousands of feet. The regional methods described in this report use streamflow and groundwater hydrographs to determine hydraulic properties. The hydraulic properties determined by these methods are considered to be regional average values because the hydrographs used in the analysis are affected by aquifer properties at scales of hundreds to thousands of feet.

The storage coefficient was calculated by using several regional methods. The first method assumes that if during a specific time an aquifer is not recharged, but is only draining, the ratio of the volume of groundwater discharged to the volume of the aquifer drained is the storage coefficient for that volume of aquifer drained. This method was applied for one time period during this study, during the summer of 2006, a year of less than average precipitation. Synoptic water-level measurements were made at different times for this study and used to produce potentiometric-surface maps. A potentiometric-surface map interpolated from synoptic waterlevel measurements from June 21 and 22, 2006, is shown in figure 19, and a potentiometric-surface map interpolated from synoptic measurements made on September 7 and 8, 2006, is shown in figure 20. Rainfall on the eastern Arbuckle-Simpson aquifer as measured at the Fittstown Mesonet weather station during the time between these two synoptic measurements was 2.5 inches (Oklahoma Mesonet, 2009), which is less than normal for that time period. The Fittstown Mesonet weather station was installed in 2005 and, therefore, no long-term average is available, but the average rainfall at the National
Weather Service weather station at Ada (about 16 mi north of the Fittstown Mesonet station) was 5.82 inches in July and August (table 3).

Streamgages measured discharge at Blue River at Connerville, Oklahoma, Pennington Creek at Reagan, Oklahoma, and Byrds Mill Spring during the time bracketed by the two synoptic water-level measurements, and the areas of the contributing subsurface watersheds were computed (see the Subsurface Watersheds section of this report). Streamflow hydrographs for these three streamgages indicated small increases in daily flow from the rainfall, but base flow (the groundwater component of stream discharge) computed by using the PART program, which computes the fraction of streamflow that is groundwater and surface water, increased by less than $1.8 \mathrm{ft}^{3} / \mathrm{s}$ on Blue River and did not increase at the Pennington Creek at Reagan, Oklahoma, streamgage. Discharge from Byrds Mill Spring is entirely groundwater and showed small increases in flow, but the increases were of a magnitude that could be introduced by measurement error in the pressure transducers and flow meters used to measure flow. The elevation of the potentiometric surface in the well at the Fittstown Mesonet station declined for the entire time period between the synoptic measurements, indicating that, at least at that location, the aquifer drained for the entire time between the two synoptic measurements (fig. 17). Although the aquifer may not have only drained during the time period between the two potentiometric surfaces, the amount of recharge added, if any, was small. The volume of aquifer drained was computed as the vertical difference between the two potentiometric measurements and the area of the subsurface watersheds. The volume of water drained was the base-flow component as computed by the PART program for the Blue River near Connerville, Oklahoma, and Pennington Creek near Reagan, Oklahoma, streamgages and the total discharge for Byrds Mill Spring. Storage coefficients calculated by this method ranged from 0.008 to 0.011 (table 10).

Another regional method used to determine the storage coefficient of the Arbuckle-Simpson aquifer was to calculate the storage coefficient as the ratio of the recharge (expressed in units of length) from individual recharge events to the corresponding change in head (also in units of length) in

Table 10. Storage coefficients calculated from streamflows and change in water stored in subsurface watersheds, June 22, 2006, through September 8, 2006.

\begin{tabular}{lcccc}
\hline $\begin{array}{c}\text { Subsurface } \\
\text { watershed }\end{array}$ & $\begin{array}{c}\text { Volume of aquifer } \\
\text { drained in subsurface } \\
\text { watersheds (acre-feet) }\end{array}$ & $\begin{array}{c}\text { Total discharge } \\
\text { based on daily gaged } \\
\text { flow (acre-feet) }\end{array}$ & $\begin{array}{c}\text { Base-flow discharge } \\
\text { based on hydrograph } \\
\text { separation (acre-feet) }\end{array}$ & $\begin{array}{c}\text { Storage coefficient } \\
\text { (dimensionless) }\end{array}$ \\
\hline Pennington Creek & 335,181 & 2,834 & 2,756 & 0.008 \\
Byrds Mill Spring $^{1}$ & 248,491 & 1,990 & 1,990 & 0.008 \\
Blue River & 454,299 & 5,187 & 5,063 & 0.011 \\
\hline
\end{tabular}

${ }^{1}$ Discharge from Byrds Mill Spring is entirely groundwater. 
a well caused by that recharge event (table 11). For this method, changes in water levels were assumed to be entirely caused by water added as recharge near each well. All wells selected for application of this method were relatively shallow, ranging in depth from 53 to $257 \mathrm{ft}$. The time period for this analysis was from July 1, 2004 to May 6, 2006. The amount of recharge for individual recharge events was determined by the RORA program (as described in the Recharge subsection in the Groundwater section of this report) at the Blue River near Connerville, Oklahoma, and Pennington Creek near Reagan, Oklahoma, streamgages, and the change in head was determined from water-level recorders distributed across the aquifer (fig. 25). Wells are identified in figure 25 by the Oklahoma Water Resources Board well identification number. Storage coefficients were calculated for most wells for more than one recharge event. For instance, storage coefficient was calculated for well 86822 for 11 recharge events. Sometimes multiple recharge events from multiple precipitation events happened during these periods of rise in groundwater over a period of time. In such situations, precipitation accumulates and causes a continuous rise in groundwater level. When this precipitation accumulation happened, recharge amounts were summed to compute the total recharge for the period and were divided by the total change in head to determine the storage coefficient. Determinations were done manually to identify distinct recharge and precipitation events.

As an example, the change in water level for January 2 through 6,2005 , in well 85182 was 48.2 inches (4.02 $\mathrm{ft}$ ) and the corresponding recharge was determined to be 3.61 inches $(0.3005 \mathrm{ft})$. Therefore, the storage coefficient

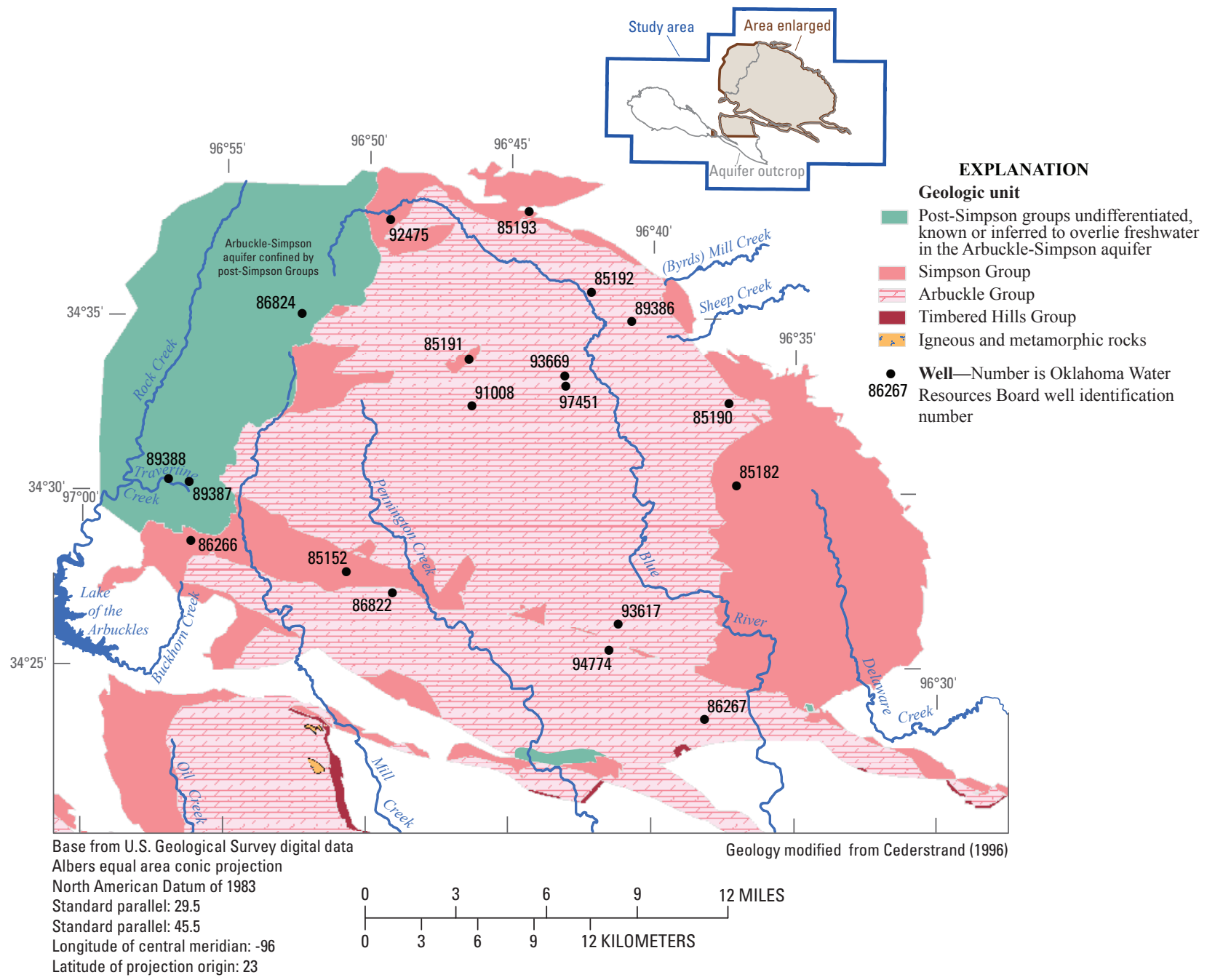

Figure 25. Wells equipped with instruments to measure water levels continuously in the eastern Arbuckle-Simpson aquifer, south-central Oklahoma. 
for this well for these rainfall/recharge events is 0.07475 . Similar determination of storage coefficients computed from 10 wells (37 individual determinations) ranged from 0.00211 to 0.07475 with a mean value of 0.00926 , a median value of 0.00646 , a 25 th percentile of 0.00433 , and a 75 th percentile of 0.00925 (table 11). The range and average of storage coefficient calculated by this method were of similar magnitude to the ranges and averages of other methods used to calculate the storage coefficient of this aquifer.

\section{Other Determinations of Hydraulic Properties}

Rahi and Halihan (2009) calculated hydraulic properties of the Arbuckle-Simpson aquifer as part of the ArbuckleSimpson Hydrology Study. That report described analysis of water-level fluctuations in wells completed in the aquifer induced from changes in barometric pressure and ocean and earth tides to determine specific storage, storage coefficient, and porosity of the aquifer. Their analysis considered wells

Table 11. Storage coefficients determined as the ratio of recharge to increase in height of the potentiometric surface in wells equipped with pressure transducers and data loggers from July 1, 2004, to May 6, 2006.

[OWRB, Oklahoma Water Resources Board; 07332390, Blue River near Connerville; 07331300, Pennington Creek near Reagan]

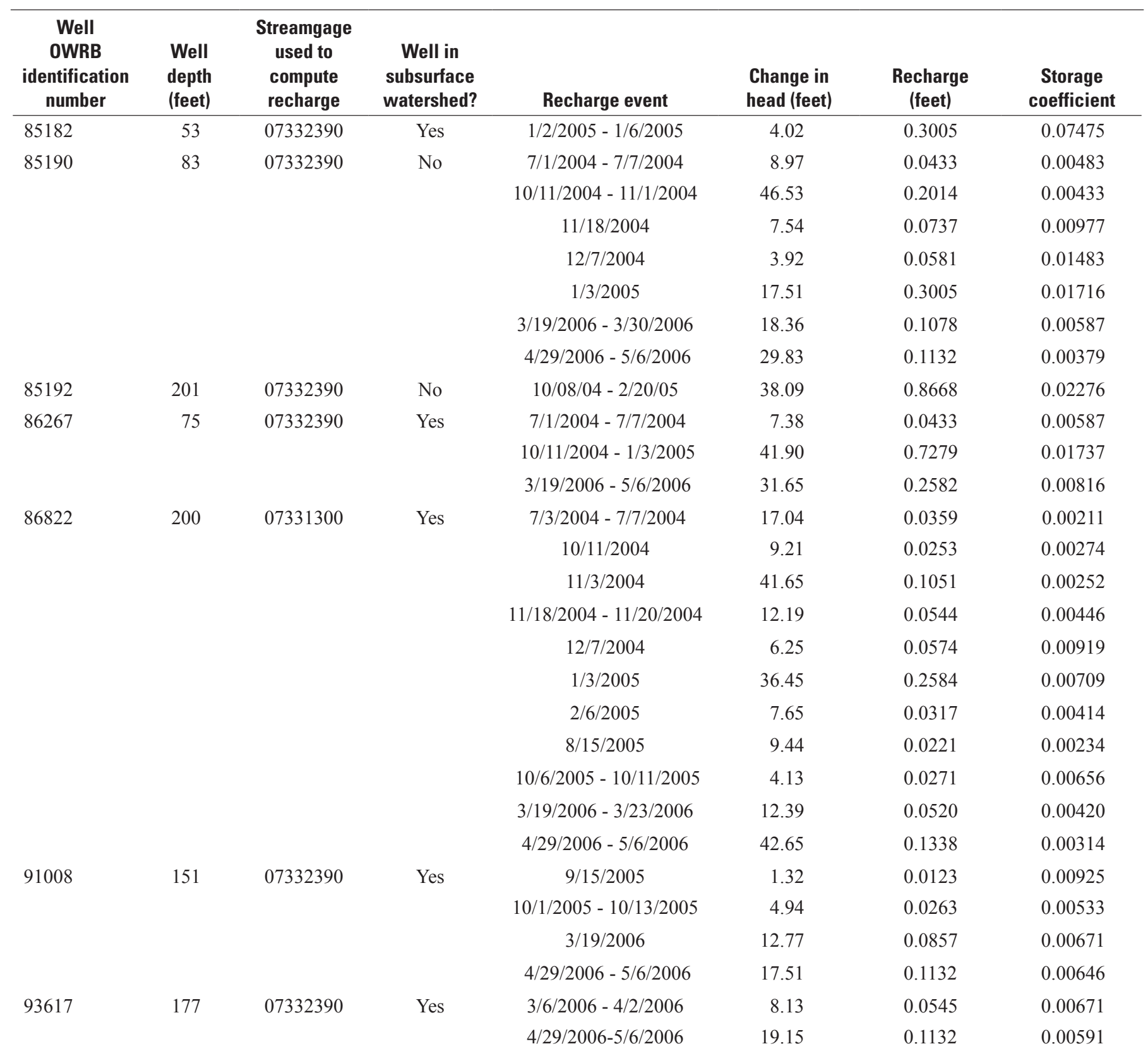


Table 11. Storage coefficients determined as the ratio of recharge to increase in height of the potentiometric surface in wells equipped with pressure transducers and data loggers from July 1, 2004, to May 6, 2006.-Continued

[OWRB, Oklahoma Water Resources Board; 07332390, Blue River near Connerville; 07331300, Pennington Creek near Reagan]

\begin{tabular}{|c|c|c|c|c|c|c|c|}
\hline $\begin{array}{c}\text { Well } \\
\text { OWRB } \\
\text { identification } \\
\text { number }\end{array}$ & $\begin{array}{l}\text { Well } \\
\text { depth } \\
\text { (feet) }\end{array}$ & $\begin{array}{l}\text { Streamgage } \\
\text { used to com- } \\
\text { pute recharge }\end{array}$ & $\begin{array}{c}\text { Well in } \\
\text { subsurface } \\
\text { watershed? }\end{array}$ & Recharge event & $\begin{array}{c}\text { Change in head } \\
\text { (feet) }\end{array}$ & Recharge (feet) & $\begin{array}{c}\text { Storage } \\
\text { coefficient }\end{array}$ \\
\hline \multirow[t]{5}{*}{93669} & 73 & 07332390 & No & $8 / 15 / 2005$ & 3.03 & 0.0293 & 0.00968 \\
\hline & & & & $9 / 15 / 2005$ & 1.88 & 0.0123 & 0.00653 \\
\hline & & & & $10 / 6 / 2005$ & 4.07 & 0.0188 & 0.00463 \\
\hline & & & & 3/19/2006 - 3/30/2006 & 6.60 & 0.1078 & 0.01635 \\
\hline & & & & 4/29/2006 - 5/6/2006 & 15.18 & 0.1132 & 0.00745 \\
\hline 94774 & 149 & 07331300 & Yes & 4/29/2006 - 5/6/2006 & 46.28 & 0.1338 & 0.00289 \\
\hline \multirow[t]{9}{*}{97451} & 257 & 07332390 & No & $3 / 19 / 2006-3 / 30 / 2006$ & 9.51 & 0.1078 & 0.01134 \\
\hline & & & & $4 / 29 / 2006-5 / 6 / 2006$ & 20.66 & 0.1132 & 0.00548 \\
\hline & & & & Statistics & & & \\
\hline & & & & Median & & & 0.00646 \\
\hline & & & & Mean & & & 0.00926 \\
\hline & & & & Maximum & & & 0.07475 \\
\hline & & & & Minimum & & & 0.00211 \\
\hline & & & & 25th percentile & & & 0.00433 \\
\hline & & & & 75th percentile & & & 0.00925 \\
\hline
\end{tabular}

to be completed in confined, semiconfined, and unconfined parts of the aquifer based on analyses of the hydraulic response of individual wells; they did not delineate confined, semiconfined, and unconfined parts of the aquifer on an areal basis. Rahi and Halihan (2009) reported specific storage of the entire Arbuckle-Simpson aquifer to be $1.056 \times 10^{-5} \mathrm{~m}^{-1}(3.219$ $\left.\times 10^{-6} \mathrm{ft}^{-1}\right), 5.6 \times 10^{-6} \mathrm{~m}^{-1}\left(1.7 \times 10^{-6} \mathrm{ft}^{-1}\right)$ for the semiconfined part, and $1.8 \times 10^{-5} \mathrm{~m}^{-1}\left(5.5 \times 10^{-6} \mathrm{ft}^{-1}\right)$ for the confined part of the aquifer. Rahi and Halihan (2009) used the aquifer thickness from the three-dimensional geologic framework model (discussed in the Three-Dimensional Geologic Framework Modeling section of this report) to calculate a storage coefficient of 0.011 for the entire aquifer, 0.0063 for the confined part, and 0.0182 for the semiconfined part of the aquifer. These storage coefficient numbers are comparable to the numbers calculated in the Regional Methods to Determine Storage Coefficient section of this report. Rahi and Halihan (2009) also calculated an average porosity of 0.15 by analysis of the barometric efficiency of three wells.

Porosity of the Oil Creek and McLish sandstones (in the Simpson hydrostratigraphic unit) was determined by using geophysical log measurements from wells that were logged with density, neutron, or sonic porosity tools (Puckette and others, 2009). The average porosity derived from 17 wells in the Oil Creek sandstone and 14 wells in the McLish sandstone was 0.20 . However, composite porosity of the Simpson hydrostratigraphic unit is unknown. Few porosity logs are available for the Arbuckle-Timbered Hills hydrostratigraphic unit. Porosity of the Arbuckle carbonates is difficult to quantify as the aquifer consists of thick sections of low porosity carbonate that are punctuated by thin zones of vuggy, solution-enlarged fractures or cavernous porosity (Puckette and others, 2009).

The potentiometric-surface map in Fairchild and others (1990, plate 2) shows the hydraulic gradient is larger in the Arbuckle-Timbered Hills hydrostratigraphic unit in the western Arbuckle-Simpson aquifer than in the eastern Arbuckle-Simpson aquifer. The recharge rate in the western Arbuckle-Simpson aquifer was similar to the recharge rate in the eastern Arbuckle-Simpson aquifer (see the Recharge subsection in the Groundwater section of this report), and therefore the larger gradient in the western ArbuckleSimpson aquifer implies that the transmissivity of the western Arbuckle-Simpson aquifer is less than the transmissivity in the eastern Arbuckle-Simpson aquifer. This difference may be attributable to the differences in rock type between the western and eastern Arbuckle-Simpson aquifer; the Arbuckle Group is predominantly limestone in the western Arbuckle-Simpson aquifer but predominantly dolostone in the eastern ArbuckleSimpson aquifer. The process of dolomitization increases porosity and permeability (Weyl, 1960). 


\section{Groundwater Withdrawals}

Permitted users of groundwater in Oklahoma are required by statute to report their water use to the Oklahoma Water Resources Board (OWRB). The OWRB does not require permits for the following uses: household, farm and domestic animal, irrigation of less than 3 acres, non-household drinking water and restroom use less than 5 acre-ft per year, and pit dewatering during mining operations. As a result, the reported water use described in this report does not include groundwater used for those activities. Groundwater use is documented in this report starting in 1964 because then-new technologies allowed for better data management and storage of water-use information at the OWRB (Oklahoma Water Resources Board, written commun., 2009).

Public water supply users (the term "public water supply" refers to the use of water for drinking water by municipalities, rural water districts, housing additions, trailer parks, churches, and schools) generally have multiple wells for each groundwater permit and reported water use generally is by permit, not for the individual well. The approximate contribution for each well was documented by dialog between OWRB staff and the water superintendent at each water utility, and a percentage of the total use was assigned to each well on the permit. This task was done to assign groundwater use for each permit to specific locations on the MODFLOW model grid (see the Simulation of Groundwater Flow section in this report).

Most of the reported groundwater use is from the eastern part of the Arbuckle-Simpson aquifer; as of 2008 there were no permitted users in the western part of the aquifer and only two from the central part of the aquifer. Average annual reported groundwater use from the eastern Arbuckle-Simpson aquifer from 1964 through 2008 was 4,299 acre-ft with a median annual use of 3,532 acre-ft. Minimum and maximum use was 2,287 acre-ft in 1972 and 8,347 acre-ft in 2006, respectively. Figure 26 shows annual water use from 1964 to 2008 of the eastern Arbuckle-Simpson aquifer and a breakdown of each use.

Historically, most of the water used from the eastern Arbuckle-Simpson aquifer serves public water supply systems with an average annual reported use from 1964 to 2008 of 2,697 acre-ft, or 63 percent of the total groundwater use, followed by mining (15 percent or an annual average of 648 acre-ft), which utilizes water from the aquifer to wash product and for dust suppression, and irrigation (7 percent or an annual average of 301 acre-ft). Power generation accounted for an annual average of 586 acre-ft (14 percent of the total groundwater used); however, groundwater use for power generation from the aquifer ceased by 1988 when the Oklahoma Gas and Electric Company discontinued operating a power plant north of Sulphur, Oklahoma. Other uses (including

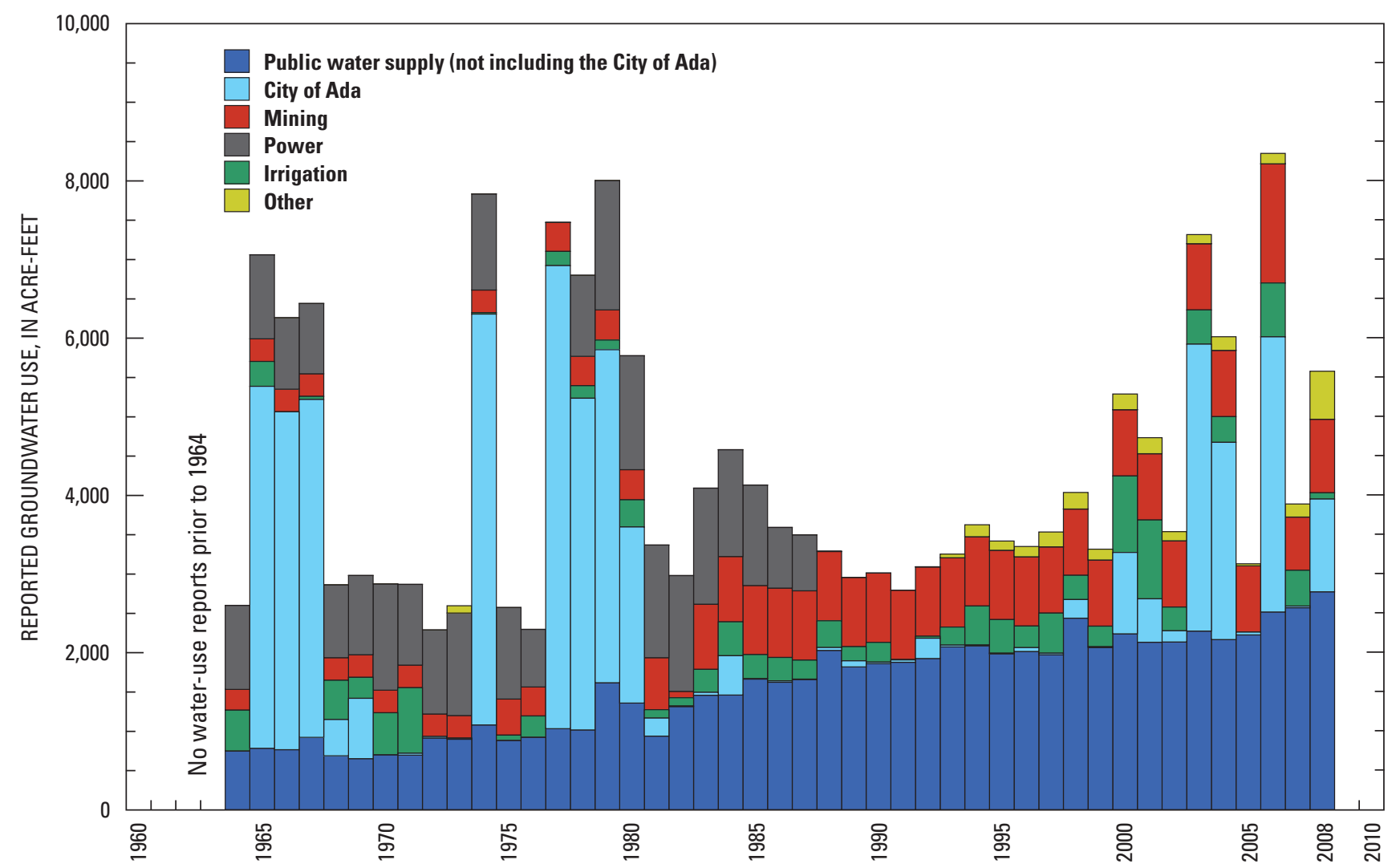

Figure 26. Reported groundwater use from the eastern Arbuckle-Simpson aquifer, south-central Oklahoma, 1964-2008. 
recreation and non-irrigation agricultural use) accounted for about 1 percent of groundwater use.

The two largest consumers of groundwater from the eastern Arbuckle-Simpson aquifer from 1964 to 2008 were the cities of Ada (annual average 1,122 acre-ft) and Sulphur, Oklahoma (annual average 957 acre-ft). The cities of Sulphur and Ada, Oklahoma, combined accounted for 77 percent of the average annual public water-supply use and 48 percent of the total water use from the aquifer. However, Ada's minimum and maximum groundwater use ranged from 0 in 1964, 1970, 1975 , and 1976 to 5,889 acre-ft in 1997 , with a median of 78 acre-ft per year. For comparison, median annual water use by the City of Sulphur was 936 acre-ft. The large variation in reported groundwater use by the City of Ada is largely related to variation in discharge from Byrds Mill Spring, Ada's primary water source. When discharge from Byrds Mill Spring is adequate to meet demand, the City of Ada meets that demand by diverting water from the spring and does not withdraw groundwater. Water diverted from Byrds Mill Spring is reported as surface-water use, and therefore, in years when the flow from Byrds Mill Spring is adequate to meet demand, Ada's reported groundwater use is zero. When discharge from the spring is low, Ada supplements water from the spring by withdrawing groundwater from wells completed in the aquifer to preserve streamflow for downstream landowners.

Anomalously high-use years (1965-7, 1974, 1977-80, 2003-4, and 2006) correspond to years that the City of Ada reported withdrawals exceeding 2,000 acre-ft. According to Ada city managers, the anomalous use in 1974 most likely resulted from a pipe leak. In addition, from 1977 to 1980, Ada also supplied water to a nearby rural water district.

\section{Changes in Groundwater Use}

Groundwater-use statistics were derived for three timeframes to determine changes in the use of the aquifer: 1964-87, 1988-2002, and 2003-8. The Oklahoma Gas \& Electric power plant north of Sulphur, Oklahoma, ceased operations in 1987 and, as a result, groundwater for power generation declined to zero by 1988 ; water-use data from
1988 to 2002 were grouped to represent this shift in the groundwater use. Water-use data also were grouped for the timeframe 2003 through 2008, which represents groundwater use during the course of the Arbuckle-Simpson Hydrology Study. Table 12 compares the average, median, minimum, and maximum reported groundwater use for the three timeframes. Highly variable groundwater use by the City of Ada has been separated from the public water-supply use in figure 26 and table 13 to show that public water-supply use has increased since 1964.

Average annual reported groundwater use from the eastern Arbuckle-Simpson aquifer from 1964 through 1987 was 4,415 acre-ft with power generation consuming 1,099 acre-ft, or 25 percent of the average annual groundwater use (table 13). After the Oklahoma Gas \& Electric power plant ceased operations in 1987, average annual reported groundwater use declined to 3,548 acre-ft from 1988 through 2002. However, mining use increased and offset some of the decline in reported groundwater use between these timeframes. Additionally, during the 1988-2002 timeframe, average annual groundwater use by the City of Ada decreased from 1,545 acre-ft during 1964-87 to 167 acre-ft. This decrease in water use may be attributable to increased precipitation in the region during the late 1980s and the early 1990s (fig. 13), which caused greater flows from Byrds Mill Spring and less dependence of the City of Ada on groundwater withdrawals.

Reported groundwater use from 2003 to 2008 indicated a 61 percent increase in the average annual use from the 1988

Table 12. Reported groundwater-use statistics for the eastern Arbuckle-Simpson aquifer, south-central Oklahoma, 1964-2008.

\begin{tabular}{lcccc}
\hline & \multicolumn{4}{c}{ Reported annual water use (acre-feet) } \\
\hline \multirow{2}{*}{ Average } & $\mathbf{1 9 6 4 - 2 0 0 8}$ & $\mathbf{1 9 6 4 - 8 7}$ & $\mathbf{1 9 8 8 - 2 0 0 2}$ & $\mathbf{2 0 0 3 - 8}$ \\
\cline { 2 - 5 } Median & 4,299 & 4,415 & 3,548 & 5,712 \\
Minimum & 3,532 & 3,543 & 3,348 & 5,796 \\
Maximum & 2,287 & 2,287 & 2,792 & 3,128 \\
\hline
\end{tabular}

Table 13. Average annual reported groundwater use by type for the eastern Arbuckle-Simpson aquifer, south-central Oklahoma,1964-2008.

[PWS, public water supply]

\begin{tabular}{|c|c|c|c|c|c|c|c|c|}
\hline & \multicolumn{8}{|c|}{ Average annual reported water use (acre-feet) } \\
\hline & PWS & $\begin{array}{c}\text { PWS (ex- } \\
\text { cluding City } \\
\text { of Ada) }\end{array}$ & City of Ada & Mining & Irrigation & Power & Other & Total \\
\hline $1964-87$ & 2,618 & 1,073 & 1,545 & 438 & 248 & 1,099 & 11 & 4,415 \\
\hline $1988-2002$ & 2,208 & 2,041 & 167 & 866 & 373 & 0 & 101 & 3,548 \\
\hline
\end{tabular}


to 2002 timeframe (from 3,548 acre-ft to 5,712 acre-ft). Mining use steadily increased during the three timeframes with the maximum use at 1,516 acre-ft in 2006. While most of the use types remained steady, public water supply increased about 93 percent, from 2,208 acre-ft in 1988-2002 to 4,235 acre-ft in 2003-8. Examination of figure 26 indicates that the high reported uses in 2003, 2004, 2006, and 2008 were primarily caused by groundwater withdrawals by the City of Ada.

Figure 27 illustrates that the northern and western parts of the eastern Arbuckle-Simpson aquifer have had the largest amount of reported groundwater use from 2003 to 2008.

\section{Estimated Nonpermitted Use}

Annual groundwater withdrawals for nonpermitted agriculture (livestock) and household purposes were estimated for the eastern Arbuckle-Simpson aquifer. Livestock estimates for the eastern Arbuckle-Simpson aquifer were about 22,300 head of cattle. An average-sized cow ( 850 pounds) at a mean annual temperature for the region consumes 10.1 gallons per day (Winchester and Morris, 1956). Therefore, livestock use for the eastern Arbuckle-Simpson aquifer was estimated to be about 250 acre-ft per year. Some cattle are watered from surface-water sources such as streams and ponds, and other cattle are watered from stock wells. According to the USGS Estimated Use of Water in the United States, Oklahoma Methods (R.L. Tortorelli, U.S. Geological Survey, written commun., 2009), groundwater and surface-water use for livestock indicated that only 10 percent of livestock consumption is from groundwater. Under these assumptions, annual estimated groundwater consumption from the eastern Arbuckle-Simpson aquifer by livestock is about 25 acre-ft, although without data to estimate the portion of water use from surface-water and groundwater sources specific to the eastern Arbuckle-Simpson aquifer, livestock use could be as large as 250 acre-ft per year.

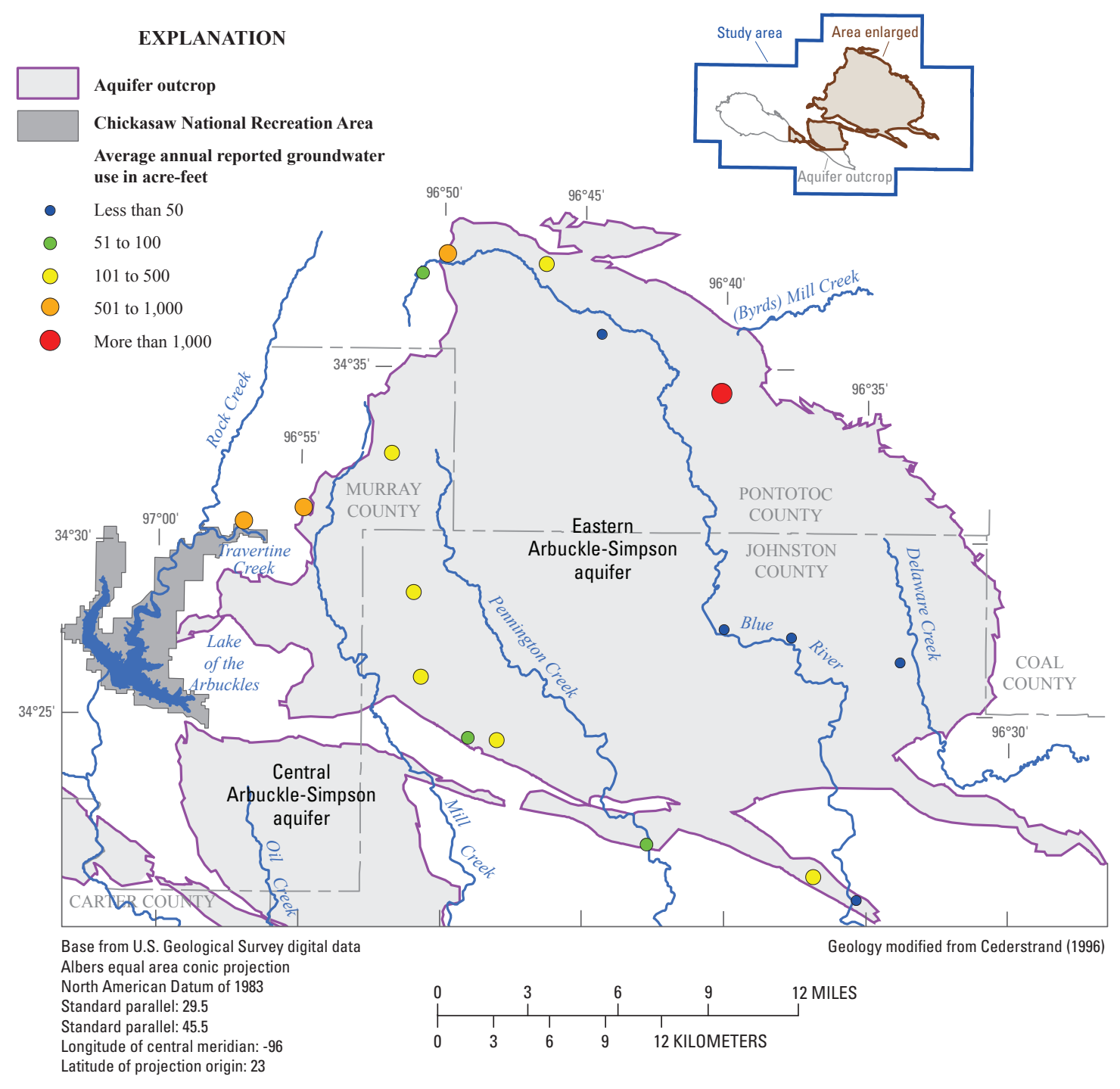

Figure 27. Average annual groundwater use from the eastern Arbuckle-Simpson aquifer, south-central Oklahoma, 2003-8. 
Human population estimates from 2000 census data (Center for Spatial Analysis, 2004) indicate that the population on and near the outcrop of the Arbuckle-Simpson aquifer is about 3,000, of which 2,200 are on and near the eastern Arbuckle-Simpson aquifer. The USGS Estimated Use of Water in the United States, Oklahoma Methods, indicated an average use of 85 gallons per day per person in Oklahoma (R.L. Tortorelli, U.S. Geological Survey, written commun., 2009). Because these estimates are for the population over the aquifer, the assumption is that the use is 100 percent groundwater. Annual water use for these populations is estimated at 285 acre- $\mathrm{ft}$ for the entire aquifer and 209 acre-ft for the eastern Arbuckle-Simpson aquifer. However, this estimate may be high for groundwater use because some of the population on the eastern Arbuckle-Simpson aquifer is serviced by public water supply utilities.

\section{Estimated Monthly Use}

Groundwater is not withdrawn from the eastern ArbuckleSimpson aquifer at a constant rate during the course of a year. Therefore, water-use data were partitioned into monthly data for use in the groundwater-flow model for the eastern Arbuckle-Simpson aquifer from 1994 through 2008. Public water supply and mining users generally submit monthly use data as part of their water-use reports. However, irrigation, agriculture (non-irrigation), and fish, recreation, and wildlife users do not typically submit their monthly water use amounts. Efforts were made to contact irrigation, agriculture, fish, and recreation permit holders to estimate monthly use and this information was used to estimate the permit holders' monthly use. For example, landowners indicate that irrigation water use in the study area is generally concentrated in the summer months of June-August, with a peak in August. Therefore, monthly use for irrigation was estimated by partitioning the reported annual totals on the 3 months as follows: 32 percent for June, 33 percent for July, and 35 percent for August. In addition, monthly usage was estimated when water-use reports were not submitted to the OWRB. These estimates are not included in any of the reported groundwater statistics. Based on these assessments, total estimated monthly groundwater withdrawals are greatest in August (12.02 percent) and least in March (6.42 percent).

\section{Conceptual Model of Flow System}

A conceptual flow-system model of the eastern ArbuckleSimpson aquifer was developed as the basis for constructing a digital groundwater-flow model. The conceptual model was based on annual precipitation, surface topography, properties and distribution of the hydrostratigraphic units, water-level data and resultant potentiometric-surface maps, hydrologic testing results, geochemical data, and previously published interpretations of the flow system. The ArbuckleTimbered Hills and Simpson hydrostratigraphic units in the model area are the principal water-bearing units. Recharge to hydrostratigraphic units in the model area is from atmospheric precipitation that infiltrates through the surficial materials of any of the hydrogeologic units that outcrop at land surface. The Arbuckle-Simpson aquifer discharges to the streams, springs, and wells based on the potentiometric surfaces developed by Fairchild and others (1990) and by this study. Some water from the aquifer flows laterally out of the outcrop area and discharges to streams and flowing wells.

Structural controls on groundwater flow include faults and fractures that may act as either barriers or conduits to flow, although no hydraulic test or water-level data are available to confirm either condition. Although some hydrogeologic units in the flow system are fractured, porous-media flow may be approximated at the model scale.

\section{Simulation of Groundwater Flow}

One of the stated objectives of the Arbuckle-Simpson Hydrology Study (see Introduction section of this report) was to, "Construct a digital groundwater/surface-water-flow model of the Arbuckle-Simpson aquifer system for use in evaluating the allocation of water rights and simulating management options." The term "groundwater-flow model" is used in this report to describe the digital groundwater/surface-water-flow model of the Arbuckle-Simpson aquifer.

A groundwater-flow model, as described in this report, is a computer program that solves equations that describe groundwater flow. A groundwater-flow model is a tool that can be used to analyze complicated flow systems and to predict the response of an aquifer to hypothetical future stresses. Groundwater-flow models have been widely used in the United States since the 1970s to analyze groundwaterflow systems and predict the effects of water development (Anderson, 1995). Groundwater-flow models have been used for more than 30 years in Oklahoma to provide the scientific basis needed to determine the maximum annual yield in accordance with Oklahoma water law (for example, Davis and Christenson, 1979).

A groundwater-flow model was developed to simulate groundwater flow in the eastern Arbuckle-Simpson aquifer. The model was restricted to the eastern Arbuckle-Simpson aquifer because the hydrogeologic data needed to build a model are sparse in the western and central Arbuckle-Simpson aquifer, the eastern Arbuckle-Simpson aquifer is the largest part of the Arbuckle-Simpson aquifer by area and volume, and most of the current (2011) water withdrawals from the Arbuckle-Simpson aquifer are from the eastern ArbuckleSimpson aquifer.

The eastern Arbuckle-Simpson MODFLOW model was optimized to simulate groundwater flow to Blue River and Pennington Creek for several reasons. One of the management objectives of the study is to consider the "potential impacts of pumping on springs and stream base flows" (Oklahoma Water 
Resources Board, 2003). Blue River and Pennington Creek are the streams in the eastern Arbuckle-Simpson aquifer with the largest flows. Streamgages were installed on these streams at the beginning of the Arbuckle-Simpson Hydrology Study, and streamflow data collected at those streamgages were used to analyze daily streamflow from the aquifer and to calibrate the MODFLOW model. Reduced streamflow results in loss of aquatic habitat, and, therefore, an in-stream flow assessment was performed for the Arbuckle-Simpson Hydrology Study by using an in-stream flow incremental methodology to relate streamflow to the aquatic habitat of selected fish. The in-stream flow incremental methodology, an in-stream flow assessment technique commonly used by state and Federal agencies, was used to assess in-stream flow requirements of selected fish on Blue River and Spring Creek, a tributary of Pennington Creek (Seilheimer and Fisher, 2008). Therefore, the eastern Arbuckle-Simpson aquifer MODFLOW model was optimized to simulate groundwater flow to Blue River and Pennington Creek.

The term "optimize" has a specific meaning in mathematics, programming, and groundwater modeling. Optimization techniques are a set of mathematical programs that seek to find the optimal (or best) allocation of resources to competing uses. In the context of groundwater management, the resources are typically the groundwater and surfacewater resources of a basin and (or) the financial resources of the communities that depend on the water (Ahlfeld and others, 2005). However, in this report the term "optimized," when used in reference to the eastern Arbuckle-Simpson groundwater-flow model, does not have this specific meaning. Groundwater flow models are constructed for specific purposes and a model designed for one purpose may not be suitable for other purposes. The process of constructing the eastern Arbuckle-Simpson groundwater-flow model required many decisions regarding the model design. Those decisions were made to favor, or optimize, a model to simulate groundwater flow to Blue River and Pennington Creek.

\section{Groundwater-Flow Model}

Groundwater flow in the eastern Arbuckle-Simpson aquifer was simulated by using MODFLOW-2000 (Harbaugh and others, 2000), referred to in this report as MODFLOW. MODFLOW simulates an aquifer as porous media, that is, water is assumed to move through small pores, such as the void space between sand grains in sandstone. In this type of simulation, an aquifer is considered to be saturated and groundwater flow is considered to be Darcian (nonturbulent) flow. If these conditions are met, and in many aquifers these conditions are met, then the mathematical treatment of this type of flow is well understood and well developed. Many different computer codes exist to simulate flow that meets these conditions, but MODFLOW is the most commonly used (Leake, 1997). The applicability of the porous media approach to the eastern Arbuckle-Simpson aquifer is discussed in the
Model Simplifications, Assumptions, and Limitations section of this report.

Many reasons exist for applying MODFLOW to simulating flow in the Arbuckle-Simpson aquifer, including (1) the finite-difference method used by MODFLOW is easy to understand and apply to a wide variety of real-world conditions; (2) each simulation feature of MODFLOW has been extensively tested; (3) data input instructions and theory are well documented; (4) a wide variety of computer programs written by the USGS, other Federal agencies, and private companies are available to analyze field data and construct input datasets for MODFLOW; (5) a wide variety of programs are available to read output from MODFLOW and graphically present model results in ways that are easily understood; and (6) MODFLOW has been accepted in many court cases in the United States as a legitimate approach to analysis of groundwater systems (Leake, 1997).

MODFLOW uses a finite-difference approach to solving the equations that describe groundwater flow. A finite-difference approach solves equations by replacing the equations at a point, known as a node, by ratios of the changes in appropriate variables over a small but finite interval (Remson and others, 1971). The volume of aquifer described by the model is divided into cells and a node is in each cell; MODFLOW locates the node at the cell center. The time of the simulation must be discretized into time intervals to use finite-difference methods for transient analyses. The process of dividing the model volume into cells and time into intervals is referred to as discretization.

\section{Temporal Discretization}

Data used for the MODFLOW model were available at different time scales. Reported groundwater use was available, or estimated, as monthly totals. Streamflow, groundwater levels, and precipitation were available as daily data. Recharge calculated from streamflow by using the RORA program was available on a daily basis, although Rutledge (1998) states that users should exercise caution in interpreting results on time scales as brief as a day. The MODFLOW model was constructed to use time intervals of one day, knowing that some results would not be meaningful at the scale of a single day and that results would be aggregated to longer time scales at the end of a model simulation.

\section{Spatial Discretization}

The eastern Arbuckle-Simpson aquifer groundwaterflow model was designed to utilize information from other models of the eastern Arbuckle-Simpson aquifer area that were developed as part of the Arbuckle-Simpson Hydrology Study. A physics-based distributed hydrologic model, VFlo (Vieux and Moreno, 2008), was used to calculate rainfall and runoff from the eastern Arbuckle-Simpson aquifer area. The VFlo model discretized the eastern Arbuckle-Simpson aquifer 
area into $200-\mathrm{m}$ (656-ft) by $200-\mathrm{m}(656-\mathrm{ft})$ cells $^{5}$ based on the Universal Transverse Mercator, North American Datum of 1927 coordinate system, so that the eastern Arbuckle-Simpson aquifer MODFLOW model was constructed to match the cells in the VFlo model. The arrays of finite-difference model cells for the MODFLOW and VFlo models are referred to as "grids" in this report.

The MODFLOW and VFlo models were not coupled in the sense that both models were running simultaneously and exchanging information. Rather, the models were done independently of each other but could exchange information in the form of arrays without interpolation because cells in both models were the same size and at the same locations. The MODFLOW model grid for the eastern Arbuckle-Simpson aquifer was extended west of the VFlo model grid, after the

${ }^{5}$ Model data were stored and computations were made in Systeme International d'Unités (SI) units; therefore, model data are expressed in SI units in this report.
VFlo model grid originally was established, to simulate flow in the confined part of the Arbuckle-Simpson aquifer overlain by the post-Simpson hydrostratigraphic unit.

Finite-difference models, such as MODFLOW, are rectangular in structure because of the requirements of the finite-difference method. Hydrologic systems are not inherently rectangular and, therefore, the irregular polygon that defines the aquifer, referred to as the model domain, is contained in the rectangular model grid. Nodes outside of the model domain but in the rectangular grid are termed "inactive," nodes in the rectangular grid that correspond to the aquifer are termed "active," and the finite-difference equations are solved at those active nodes. Locations of active nodes in the eastern Arbuckle-Simpson aquifer MODFLOW model in model layer 1 are shown in figure 28. Model cells are not shown in figure 28 because the figure would appear to be too cluttered. The total area modeled was 1,002 square $\mathrm{km}$ $\left(387.1 \mathrm{mi}^{2}\right)$.

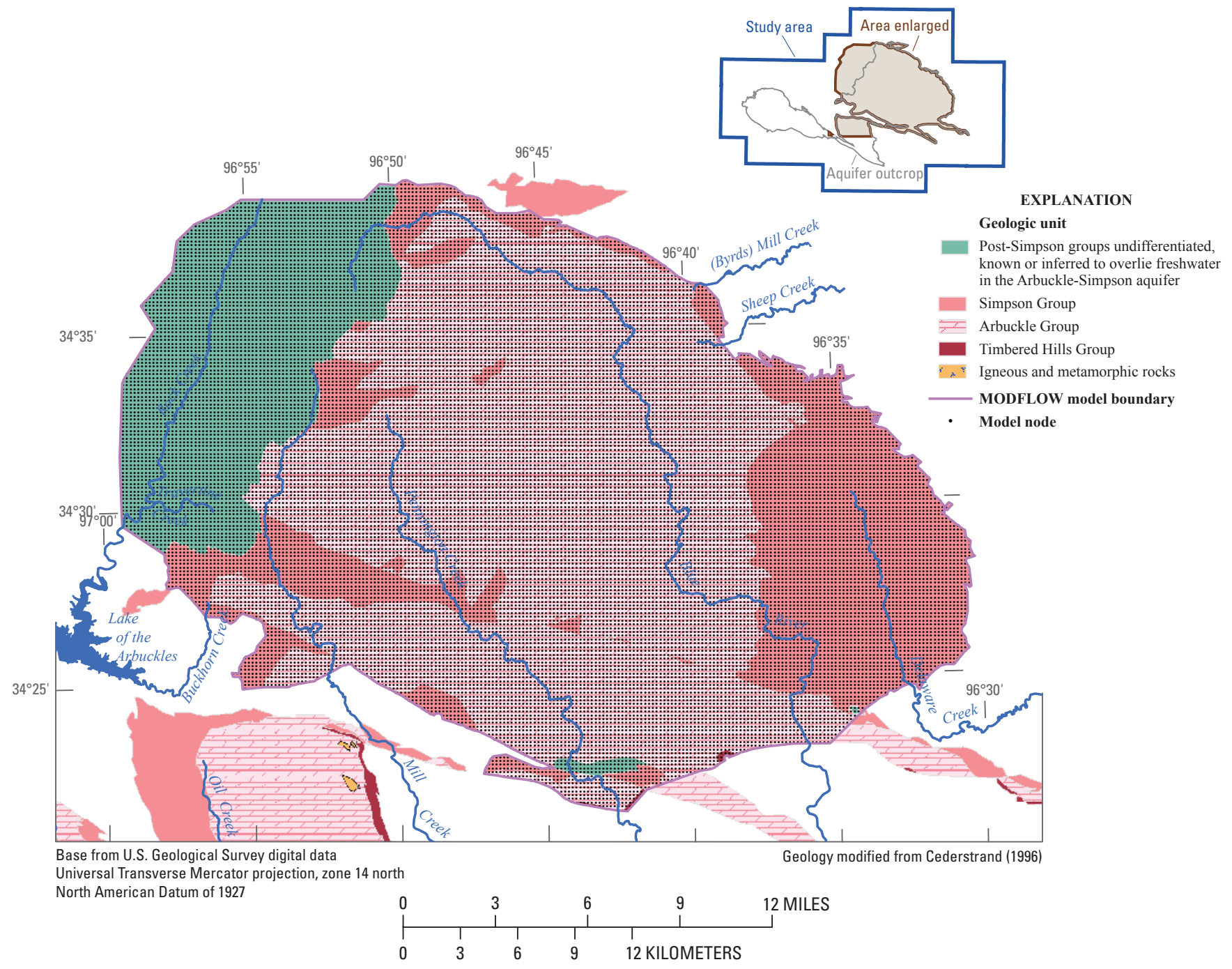

Figure 28. Eastern Arbuckle-Simpson aquifer, south-central Oklahoma, MODFLOW model active nodes in layer 1. 
Small areas in the eastern Arbuckle-Simpson aquifer, where the Arbuckle-Simpson aquifer is exposed at the land surface and presumably part of the aquifer, were not included in the MODFLOW model (fig. 28). These areas, which represent small narrow parts of the aquifer that protrude beyond the main body of the eastern Arbuckle-Simpson aquifer, were not included in the model because the geology of these areas at depth in the aquifer is poorly defined, and narrow zones of model cells tend to cause numerical problems in finite-difference models. The excluded parts of the aquifer have a total area of $7.8 \mathrm{mi}^{2}$, or 2 percent of the total area of the eastern Arbuckle-Simpson aquifer MODFLOW model of $387.1 \mathrm{mi}^{2}$.

MODFLOW cells have thickness and the sum of the thicknesses of all the MODFLOW layers approximates the total thickness of the aquifer and confining layers. The eastern Arbuckle-Simpson aquifer MODFLOW model was discretized vertically into six layers to simulate vertical flows. The decision to use six layers was based on the desire to have layers in the vertical dimension to better simulate vertical flow weighed against the limitations of computer memory and simulation time. Cells in the eastern Arbuckle-Simpson MODFLOW model in layers 1 through 5 had a constant thickness. Layers are progressively thicker with depth (table 14). Layer 6 had a varying thickness to approximate the total thickness of the aquifer. The top of layer 1 was assigned to be the altitude of the land surface at each node, and the altitude of the top of each lower layer is relative to the top of layer 1 as determined by successive layer thicknesses.

Many three-dimensional groundwater-flow models assign layers to correspond to geologic units because hydraulic properties, which are parameters in a groundwater-flow model, are often strongly related to the geologic units that form the aquifer. For example, porous sandstones generally have a higher hydraulic conductivity than shale, and a MODFLOW model could represent horizontal, alternating sand and shale geologic units by considering each individual sand and shale layer to be a single model layer and the thickness of

Table 14. Thickness of layers in the eastern Arbuckle-Simpson, south-central Oklahoma, MODFLOW model.

\begin{tabular}{cccc}
\hline Layer & $\begin{array}{c}\text { Thickness } \\
\text { (meters/feet) }\end{array}$ & $\begin{array}{c}\text { Layer } \\
\text { bottom depth } \\
\text { (meters/feet) }\end{array}$ & $\begin{array}{c}\text { Node depth } \\
\text { (meters/feet) }\end{array}$ \\
\hline 1 & $20 / 65.6$ & $20 / 65.6$ & $10 / 32.8$ \\
2 & $40 / 131$ & $60 / 197$ & $40 / 131$ \\
3 & $80 / 262$ & $140 / 459$ & $100 / 328$ \\
4 & $160 / 525$ & $300 / 984$ & $220 / 722$ \\
5 & $320 / 1,050$ & $620 / 2,034$ & $460 / 1,509$ \\
6 & variable & variable & variable \\
\hline
\end{tabular}

the model layer would be the thickness of the individual sand and shale layers. As described in the Hydrostratigraphy section of this report, the hydrostratigraphic units that form the Arbuckle-Simpson aquifer are difficult to differentiate in the subsurface and few boreholes penetrate the full thickness of the aquifer. Therefore, assigning individual model layers to represent a specific hydrostratigraphic unit was not considered to be feasible for this study. Instead, hydraulic properties in the eastern Arbuckle-Simpson MODFLOW model were assigned based on the hydrostratigraphic unit at the node in each cell. Cross sections through the model showing the vertical discretization are shown in figure 29. As described in the Three-Dimensional Geologic Framework Modeling section of this report, the geology of the eastern Arbuckle-Simpson aquifer was modeled and the thickness of the post-Simpson, Simpson, and Arbuckle-Timbered Hills hydrostratigraphic units, and the elevation of the top of the basement hydrostratigraphic unit, were exported from the geologic framework model. The tops and thicknesses of the hydrostratigraphic units exported from the geologic model were used to determine the hydrostratigraphic unit at the node at the cell center in the MODFLOW model. Area, thickness, and volume statistics for the eastern Arbuckle-Simpson aquifer, based on data exported from the geologic model, are shown in table 15 .

\section{Hydraulic Properties}

Hydraulic properties used in the MODFLOW model were assigned based on the hydrostratigraphic unit coinciding with each node. The hydraulic properties used in model simulations are horizontal hydraulic conductivity, vertical anisotropy (the ratio of horizontal to vertical hydraulic conductivity), and specific storage. These properties were assigned to each zone, and the zones corresponded to hydrostratigraphic units. In the model simulations, the hydrostratigraphic units were, from top to bottom, the post-Simpson, Simpson, Arbuckle-Timbered Hills, and basement units. The basement hydrostratigraphic unit was considered to be impermeable. The ArbuckleTimbered Hills hydrostratigraphic unit was subdivided further into zones during the model calibration process, as described in the Model Calibration section of this report.

The post-Simpson hydrostratigraphic unit is not considered to be an aquifer and functions as a confining layer to the underlying Arbuckle-Simpson aquifer. However, all confining units are capable of contributing or receiving water to or from an aquifer as vertical leakage. Even a small amount of vertical leakage can become a substantial contribution of water when considered over the entire area of the aquiferconfining layer interface. A few low-yield wells are completed in the post-Simpson hydrostratigraphic unit that overlies the western part of the eastern Arbuckle-Simpson aquifer, indicating that at least small volumes of water are moving through this hydrostratigraphic unit. Therefore, the postSimpson hydrostratigraphic unit was modeled as part of the groundwater-flow system. 

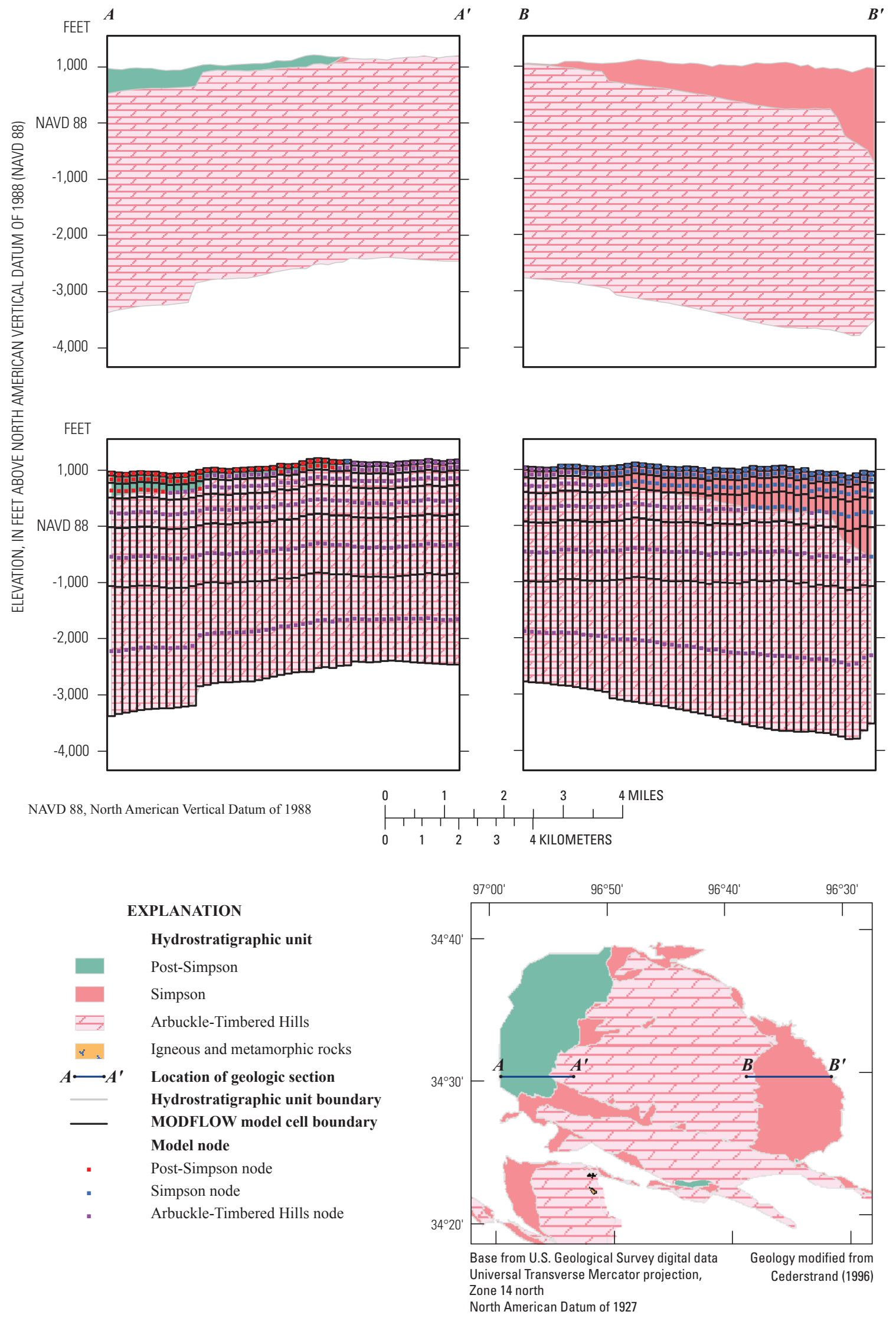

Figure 29. Cross sections through the eastern Arbuckle-Simpson aquifer, south-central Oklahoma, showing MODFLOW model discretization. 
Table 15. Area, thickness, and volume statistics calculated from the geologic framework and groundwater-flow models of the eastern Arbuckle-Simpson aquifer, south-central Oklahoma.

[*, average where present, post-Simpson and Simpson hydrostratigraphic units thin to zero at some locations in the model domain]

\begin{tabular}{|c|c|c|}
\hline \multicolumn{3}{|c|}{ Area of recharge zones } \\
\hline Zone & (square kilometers) & (square miles) \\
\hline Post-Simpson & 178.9 & 69.07 \\
\hline Arbuckle-Timbered Hills north of the Sulphur fault & 417.2 & 161.1 \\
\hline Arbuckle-Timbered Hills south of the Sulphur fault & 157.9 & 60.96 \\
\hline
\end{tabular}

Thickness of model hydrostratigraphic units

\begin{tabular}{lccc} 
& & (meters) & (feet) \\
\hline Post-Simpson & Average* & 74.51 & 244.5 \\
& Maximum & 327.1 & 1,073 \\
Simpson & Average* & 143.9 & 472.1 \\
& Maximum & 709.7 & 2,328 \\
Arbuckle-Timbered Hills & Average & 1,035 & 3,396 \\
& Maximum & 1,852 & 6,077 \\
\hline
\end{tabular}

Saturated thickness of model hydrostratigraphic units

\begin{tabular}{lccc} 
& & (meters) & (feet) \\
\hline Post-Simpson & Average* & 72.46 & 237.7 \\
\multirow{2}{*}{ Simpson } & Maximum & 300.5 & 986.0 \\
& Average* & 138.2 & 453.2 \\
Arbuckle-Timbered Hills & Maximum & 709.4 & 2,327 \\
& Average & 1,026 & 3,365 \\
& Maximum & 1,852 & 6,077 \\
\hline
\end{tabular}

Volume of model hydrostratigraphic units

\begin{tabular}{|c|c|c|}
\hline & (cubic meters) & (cubic feet) \\
\hline Post-Simpson & $1.852 \times 10^{10}$ & $6.540 \times 10^{11}$ \\
\hline Simpson & $5.283 \times 10^{10}$ & $1.866 \times 10^{12}$ \\
\hline Sum & $1.109 \times 10^{12}$ & $3.916 \times 10^{13}$ \\
\hline
\end{tabular}

Volume of water in storage

(Specific storage assumed to be $8.0 \times 10^{-6} /$ meter for all hydrostratigraphic units)

\begin{tabular}{lccc} 
& (cubic meters) & (cubic feet) & (acre-feet) \\
\hline Post-Simpson & $1.418 \times 10^{8}$ & $5.007 \times 10^{9}$ & 114,900 \\
Simpson & $4.047 \times 10^{8}$ & $1.429 \times 10^{10}$ & 328,100 \\
Arbuckle-Timbered Hills & $8.225 \times 10^{9}$ & $2.905 \times 10^{11}$ & $6,668,000$ \\
Total & $8.772 \times 10^{9}$ & $3.098 \times 10^{11}$ & $7,111,000$ \\
\hline
\end{tabular}


The Layer-Property Flow package was used to solve the groundwater flow equations in MODFLOW. The LayerProperty Flow package is an internal flow package and all the input data that define hydraulic properties are independent of cell dimensions. Layer-Property Flow reads hydraulic conductivity (either directly or by using parameters) and calculates transmissivity by using cell thickness that is determined from the vertical discretization data, and calculates leakance from vertical hydraulic conductivity and distance between nodes, which also is calculated from the vertical discretization data (Harbaugh and others, 2000).

The eastern Arbuckle-Simpson aquifer was simulated as a confined aquifer, for several reasons. As described in the Aquifer Confinement section of this report, parts of the aquifer definitely are confined, and parts of the aquifer that would appear to be unconfined have measured storage properties similar to those of confined aquifers. Another reason for simulating the entire eastern Arbuckle-Simpson aquifer as a confined aquifer is related to the methods used to simulate confined and unconfined aquifers in MODFLOW. Transmissivity is calculated for confined aquifers as the product of the thickness of the aquifer and the hydraulic conductivity, and for unconfined aquifers is calculated as the product of the saturated thickness (head minus altitude of aquifer base) and the hydraulic conductivity. Preliminary simulations showed that to meet the objectives of determining the amount of water that could be withdrawn with minimal reduction of stream and spring flow, heads would be reduced by only small amounts, and, therefore, the change in transmissivity would be small as wells were pumped, considering that the average thickness of the aquifer is on the order of 3,000 ft. Treating the modeled aquifer as confined has numerical benefits in that the solution is more linear and instability is reduced. Some areas exist at the southern edge of the aquifer where the thickness of the aquifer is small and the fractional change in transmissivity as the head changes is substantial, but these areas represent only a small part of the aquifer, and the limited benefit of updating transmissivity in small areas of thinly saturated aquifer was considered to be outweighed by the numerical benefits of treating the aquifer as confined.

\section{Drains}

Groundwater discharge from the eastern ArbuckleSimpson aquifer to streams was simulated with the MODFLOW drain package (Harbaugh and others, 2000). The MODFLOW drain package is designed to simulate the effects of drainage features that remove water from an aquifer at a rate proportional to the difference between the head in the aquifer and some fixed head or elevation, called the drain elevation, where the head in the aquifer is above that elevation. If, however, the aquifer head falls below the drain elevation, then no water is exchanged between the drain and the aquifer, and the drain has no effect on the aquifer (Harbaugh and others, 2000).

Drains were selected to represent aquifer discharge to streams because as head in the aquifer declines, the upper reaches of streams in the study area become dry, an effect which is simulated by the drain package, and streams on the eastern Arbuckle-Simpson aquifer originate on the aquifer, so methods of simulating streamflow routing, which require more data (such as stream cross sections) are not required. A disadvantage of simulating groundwater discharge with drains is that the small losses in flow that have been documented on the upper section of Blue River during some conditions (see the Streamflow section) are not simulated, but these losses were thought to be small and infrequent.

Simulation of a drain requires that the elevation of the drain be assigned at every model drain cell. Drains in the eastern Arbuckle-Simpson aquifer MODFLOW model represent streams, with constantly decreasing elevation as the stream flows downhill through the model domain. Streambed elevations were initially computed by determining the elevation of the land surface from the DEM at the point overlying the model nodes, but this approach was revised because the streams commonly do not pass over the model nodes and the land-surface DEM elevation was higher than the stream. Ultimately the drain elevations were assigned by using the lowest elevation in the land-surface DEM in each 200-m (656-ft) by 200-m (656-ft) model cell. Manual comparison of drain elevations computed by this method to stream elevations shown on 7.5-minute topographic maps showed the elevations to be comparable.

Drains are simulated in groundwater-flow models at the discharge points such as streams and springs. Some judgment is required in locating drains; for example, in the upper reaches of a stream, flow is intermittent and a decision is made at what point along the stream channel to stop simulating drains. The drain cells in the eastern ArbuckleSimpson aquifer MODFLOW model (fig. 30) initially were set to correspond to the streams in the VFlo model, but some additional drains were established at locations that did not correspond to streams in the VFlo model. When the MODFLOW model was extended to the west, beyond the VFlo model, drains were assigned to the main channels of Rock and Travertine Creeks. Drains also were set at some springs and small streams along the eastern edge of the eastern Arbuckle-Simpson aquifer, such as Byrds Mill and Sheep Creek Springs (fig. 16), which were not streams in the VFlo model because of little runoff (VFlo simulates rainfall and runoff, not groundwater).

The hydraulic conductance of the interface between the aquifer and the drains was set to a large, uniform value at all drains, 1,000 m/day (3,281 ft/day). Streams flowing across the eastern Arbuckle-Simpson aquifer are in bedrock channels with almost no alluvial deposits, and therefore, streams are well connected to groundwater. 


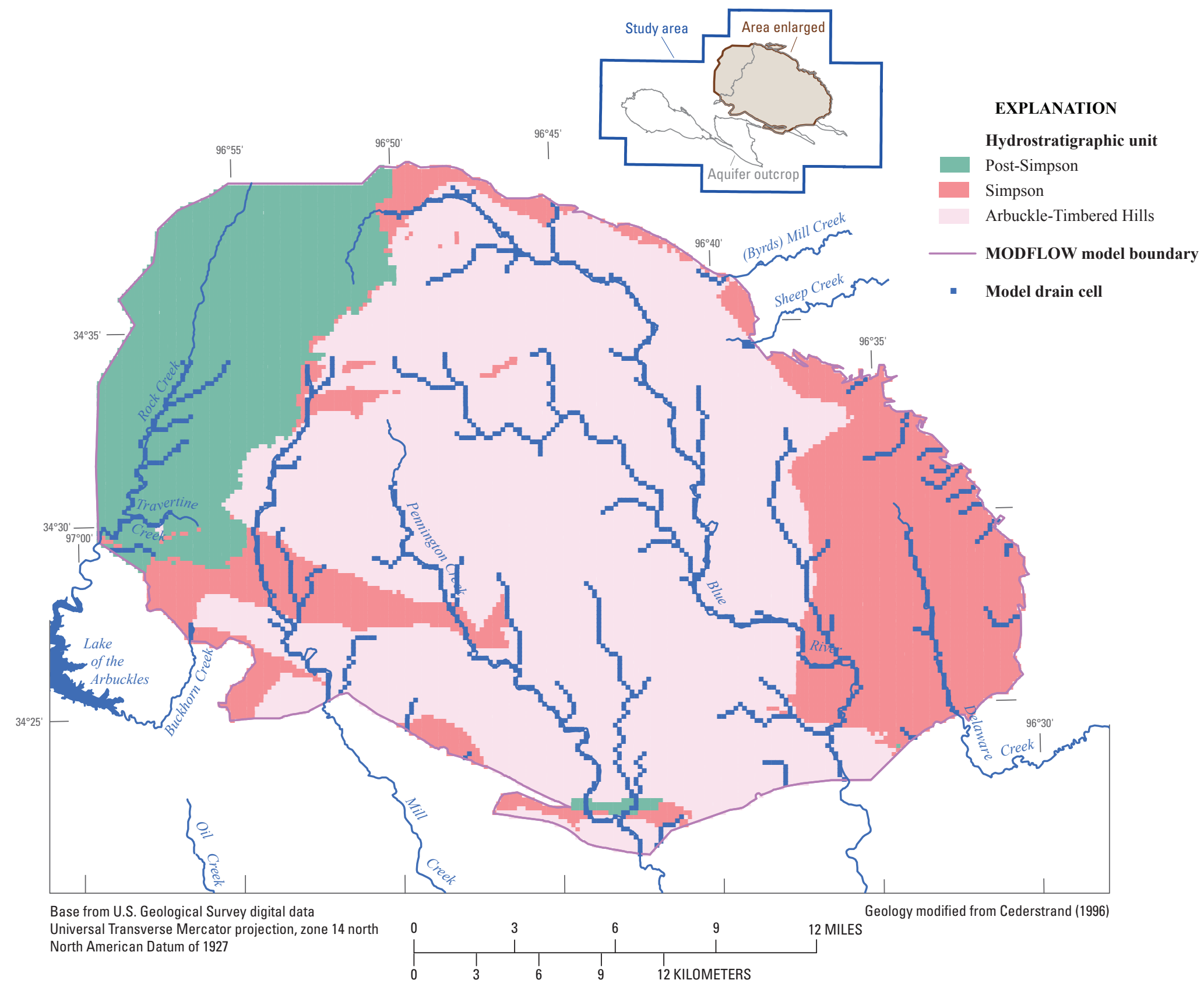

Figure 30. Drain cells in the eastern Arbuckle-Simpson aquifer, south-central Oklahoma, MODFLOW model. 


\section{Recharge}

Recharge was simulated by using the MODFLOW recharge package, which simulates areal recharge from infiltration of precipitation through the soil zone. Recharge was only applied at the land surface, which is layer 1 in the eastern ArbuckleSimpson aquifer MODFLOW model. Recharge was distributed in the eastern Arbuckle-Simpson aquifer model by zones based on the hydrostratigraphic unit at the land surface (fig. 31). Three recharge zones initially were assigned: Arbuckle-Timbered Hills, Simpson, and post-Simpson units (the basement hydrostratigraphic unit was not active in the model and received no recharge). The Arbuckle-Timbered Hills recharge zone was subdivided during the calibration process into Arbuckle-Timbered Hills zone north of the Sulphur fault and Arbuckle-Timbered Hills zone south of the Sulphur fault (see the Model Calibration section of this report).

The recharge zones were similar but not identical to the hydrostratigraphic unit assigned for hydraulic properties for layer 1. Hydraulic properties were assigned on the basis of the geology at the center of the cell in layer 1, at a depth of $10 \mathrm{~m}$, but recharge was assigned based on the geology at the center of each model cell on the land surface. At the edge of the outcrop of the post-Simpson and Simpson hydrostratigraphic units, the thickness of those hydrostratigraphic units was less than $10 \mathrm{~m}$, and, therefore, the hydrostratigraphic unit at the land surface could be different than the hydrostratigraphic unit at a depth of $10 \mathrm{~m}$. Additionally, although the geologic model used the geologic map as data, small differences are apparent between the geologic map and geologic model where the hydrostratigraphic units are thin. Recharge was assigned on the basis of the geology at the land surface because recharge is influenced by the surficial geology, even at a layer less than $10 \mathrm{~m}$ thick. The areas where there are differences between the surficial geology recharge zones and the hydraulic properties assigned on the basis of the geology at the cell center in layer 1 are shown in figure 31.

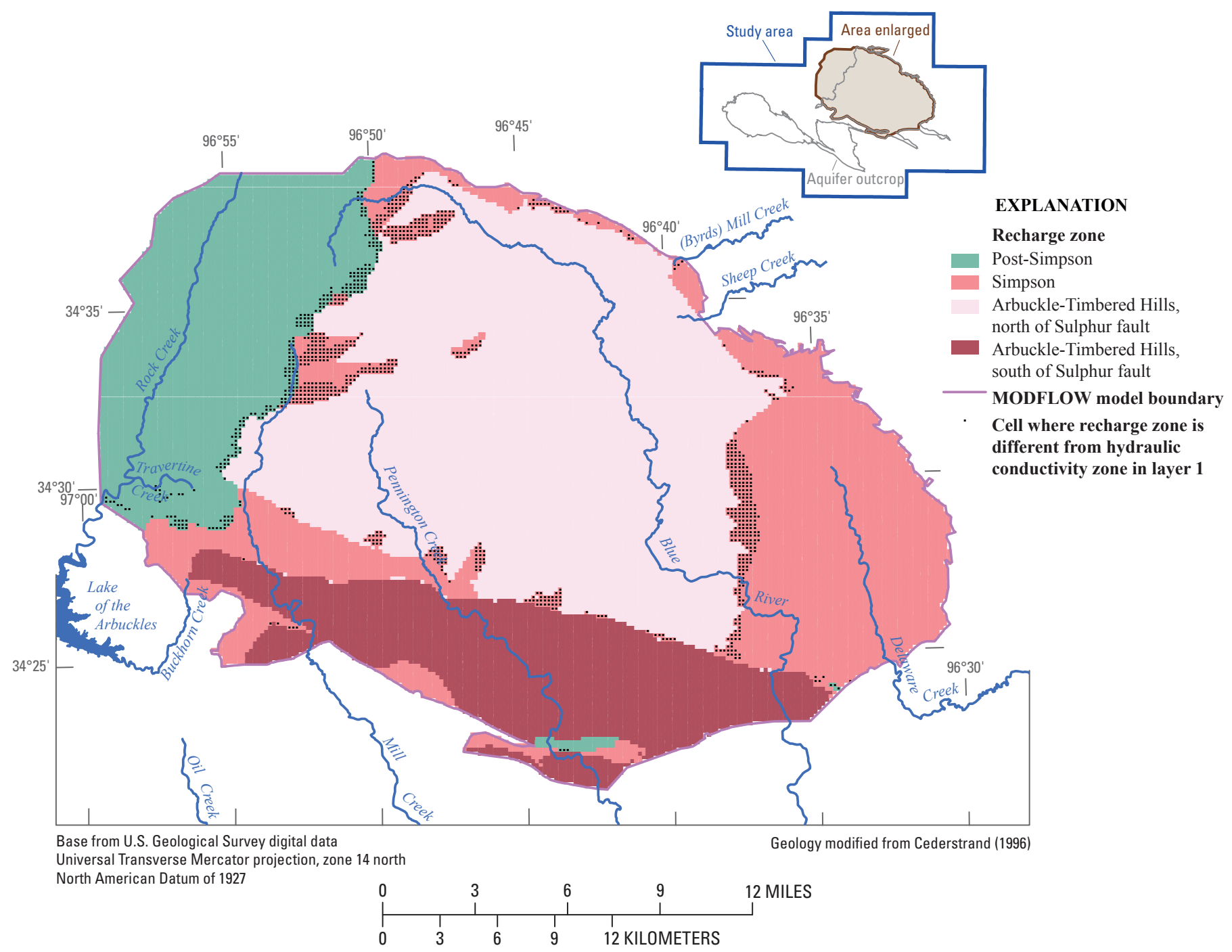

Figure 31. Eastern Arbuckle-Simpson aquifer, south-central Oklahoma, MODFLOW model recharge zones. 
Daily recharge rates calculated by using the RORA program and daily streamflow data from the Blue River near Connerville, Oklahoma, and Pennington Creek near Reagan, Oklahoma, streamgages were initially used for calculating recharge for the MODFLOW model (see the Recharge subsection in the Groundwater section of this report). Modeled daily recharge rates were adjusted from those data during the simulation calibration process (see the Model Calibration section of this report).

\section{Boundary Conditions}

The MODFLOW model simulated the boundary of the eastern Arbuckle-Simpson aquifer as being surrounded by no-flow cells. The aquifer base is igneous and metamorphic rocks, and the crystalline structure of these rocks is thought to have low hydraulic conductivity (no high-yield wells are known in the igneous and metamorphic rocks near the aquifer). The southern extent of the eastern Arbuckle-Simpson aquifer also abuts igneous and metamorphic rocks. The Franks fault zone, with large fault displacements (greater than 1,000 ft), bounds the eastern Arbuckle-Simpson aquifer on the northeast, and the Mill Creek fault, also with large fault displacement, bounds the aquifer on the southwest. Displacement along these faults causes rocks of lower hydraulic conductivity to abut the Arbuckle-Simpson aquifer. The Arbuckle-Timbered Hills and Simpson hydrostratigraphic units extend into the subsurface to the north, west, and east but contain saline water, indicating that those parts of the aquifer are not part of the freshwater flow system, and thus, were modeled as no-flow boundaries at the inferred fresh/saline water interface.

\section{Model Calibration}

Model calibration is the adjustment of the parameters of a numerical model to minimize the difference between observed and simulated water levels, streamflows, and spring discharges. Calibration of groundwater-flow models is a complicated procedure, and a thorough discussion of the process is beyond the scope of this report; only a basic discussion is included, sufficient to describe the procedure used in this study. Many texts are available for detailed information about model calibration. Calibration of the eastern Arbuckle-Simpson aquifer MODFLOW model used some of the principles discussed in Hill and Tiedeman (2007).

Independent measurements, commonly from observations or tests made in the field, of hydraulic properties and flows commonly are used as the initial values of model parameters. However, these measurements have uncertainties, and hydraulic properties can vary over orders of magnitude in the area corresponding to a model cell. Therefore, selected parameters are adjusted during the calibration process to find values that best represent that property at the scale of model cells.
Groundwater-flow models often are calibrated in two steps, referred to as "steady-state" and "transient" calibration steps. In steady-state calibration, a model is assumed to represent a single moment in time when flows and water in storage are constant. Model parameters are adjusted to match a single set of synoptic (contemporaneous) observations of heads and flows, observations that are assumed to represent a steady-state condition. This assumed steady-state condition is never achieved in reality in an aquifer, but if the synoptic observations of head and flows are made during a time when large changes in stresses or storage are lacking (such as at a time when the effects of precipitation have dissipated) then the steady-state assumption is considered to be acceptable. A transient calibration matches head and flow observations during some time period when heads and flows are changing.

\section{Steady-State Calibration}

The eastern Arbuckle-Simpson aquifer steady-state MODFLOW model was calibrated to a set of synoptic head measurements made during August 7-11, 1995; corresponding streamflow measurements were made on August 14, 1995 (table 16). Those observations were assumed to represent a steady-state condition because the observations were made at a time after the dissipation of precipitation (no surfacewater runoff was in the stream channels) and groundwater levels changed little. During August 7-11, 1995, the daily average water level fell in the USGS Fittstown Observation Well (shown as site 89386 on fig. 25) by $0.75 \mathrm{ft}$ or 0.022 percent of the average saturated thickness of the ArbuckleTimbered Hills hydrostratigraphic unit of 3,396 ft. During August 1995, the daily average water level in the USGS Fittstown Observation Well fell by $5.36 \mathrm{ft}$ or 0.16 percent of the average saturated thickness of the Arbuckle-Timbered Hills hydrostratigraphic unit. Head observations were the same observations used to generate the August 1995 potentiometricsurface map of the eastern Arbuckle-Simpson aquifer (fig. 18).

Depth to water, date of observation, latitude, longitude, elevation of land surface, and depth of well data were retrieved from the USGS Groundwater Site Inventory database (http://nwis.waterdata.usgs.gov/ok/nwis/gwlevels) for the August 1995 measurements. The August 1995 depth-to-water measurements were made in supply wells (such as domestic, stock, and public water-supply wells), not in monitoring wells. Supply wells are not ideal observation points because supply wells often have long open intervals and head can vary along the length of the borehole. Head observations are assigned to a flow-model layer, which is problematic because many eastern Arbuckle-Simpson aquifer wells are completed as open boreholes (with only a surface casing and no screen) and span several model layers. A logical way to assign a layer to a head observation is to assign the observation to the layer with the largest hydraulic conductivity because that layer tends to dominate the head in a well, but in the eastern ArbuckleSimpson aquifer the part of the well that is contributing the most flow was not known. A decision was made for the eastern 
Table 16. Streamflow measurements in the Arbuckle-Simpson aquifer, south-central Oklahoma, study area on August 14, 1995.

[Synoptic, streamflow measurement made in field; DV, USGS daily value from streamgage; $\mathrm{ft}^{3} / \mathrm{s}$, cubic feet per second]

\begin{tabular}{cllc}
\hline $\begin{array}{c}\text { USGS station } \\
\text { identifier }\end{array}$ & \multicolumn{1}{c}{ Stream name } & Source & Discharge (ft's $\mathbf{s})$ \\
\hline 07329852 & Rock Creek at Sulphur & USGS DV & 15 \\
07329882 & Buckhorn Creek below Lowrance Spring near Drake & Synoptic & 5.28 \\
07331200 & Mill Creek near Mill Creek & Synoptic & 6.6 \\
07331210 & Threemile Creek at Mill Creek & Synoptic & 0.393 \\
07331257 & Sixmile Creek near Mill Creek & Synoptic & 0.344 \\
07331305 & Pennington Creek at Reagan & Synoptic & 24.2 \\
07331310 & Keel Creek near Reagan & Synoptic & 0.07 \\
07331407 & Buzzard Creek east of Reagan & Synoptic & 0.233 \\
07332290 & Blue River at Roff & Synoptic & 0.174 \\
07332390 & Blue River near Connerville & Synoptic & 82.8 \\
07332392 & Pecan Creek near Reagan & Synoptic & 0.226 \\
07334200 & Byrds Mill Spring near Fittstown & USGS DV & 21 \\
07334215 & Walnut Creek at Fittstown & Synoptic & 0.53 \\
07334240 & Sheep Creek near Fittstown & Synoptic & 4.91 \\
07334247 & Canyon Creek near Harden City & Synoptic & 0.88 \\
07334430 & Delaware Creek southwest of Bromide & Synoptic & 1.92 \\
07334438 & Wide Springs Branch at Bromide (estimated) & Synoptic & 0.1 \\
& Total & & 164.7 \\
\hline
\end{tabular}

Arbuckle-Simpson aquifer MODFLOW model to assign the head observation to the layer at the bottom of the well. Most Arbuckle-Simpson wells are drilled until a quantity of water sufficient to meet the well owner's needs is found. Therefore, drilling stops in a productive zone that is likely to be a more permeable zone and will tend to dominate the head in the well. Accordingly, head measurements from the August 1995 dataset were formatted as head observations in the MODFLOW observation process.

Head measurements were not obtained for the postSimpson hydrostratigraphic unit that overlies the western part of the eastern Arbuckle-Simpson aquifer during the August 1995 synoptic water-level measurements. As stated in the Hydraulic Properties section of this report, the postSimpson hydrostratigraphic unit was simulated as an active part of the flow system as a confining layer, and, therefore, head observations were needed. Historic data were retrieved from the USGS Groundwater Site Inventory database for the post-Simpson area of the eastern Arbuckle-Simpson aquifer. Many of the wells listed in the database were completed in the underlying confined Arbuckle-Simpson aquifer and were not suitable for head observations in the post-Simpson hydrostratigraphic unit. A decision was made to use only the shallowest wells for head observations because those wells represent the upper boundary of the zone of saturation, so that all wells greater than $10 \mathrm{~m}(32.8 \mathrm{ft})$ deep were eliminated, leaving a total of 14 wells with head observations. Those wells are shallow and are thought to just barely penetrate into the zone of saturation and, therefore, delineate the elevation of the water table for that part of the aquifer. Depth to groundwater in those 14 wells was measured from May 15, 1962, to November 6, 2002. The distribution of hydraulic head in the post-Simpson hydrostratigraphic unit is not an issue for the Arbuckle-Simpson Hydrology Study, but the approximate upper limit of the zone of saturation was needed for the modeling process. Head observations that were not collected during the August 1995 synoptic measurement were given a lower weight during calibration than the August 1995 synoptic measurements in the MODFLOW observation process. The term "weight" refers to a mathematical coefficient assigned to each observation to represent its relative importance. Weighting reduces the influence of observations that are less accurate (Hill, 1998).

Flow observations were assigned to the model cell corresponding to the location where the synoptic flow measurement was made during the August 1995 synoptic measurements (table 16). Flow observations also were assigned at locations where streamgages were in operation on August 14, 1995, and the magnitude of the observation was the daily flow as listed on the USGS National Water Information System web site (http://waterdata.usgs.gov/nwis). 
A process generally referred to as "parameter estimation" was used to calibrate the eastern Arbuckle-Simpson aquifer steady-state model. Parameter estimation was done by using the parameter-estimation module of MODFLOW-2000. Readers are referred to Hill and Tiedeman (2007) for an in-depth description of parameter estimation. The parameterestimation process as applied to the eastern ArbuckleSimpson aquifer steady-state model consisted of a module in MODFLOW that runs the flow model, calculates fit statistics, calculates a new set of model parameters, and runs the model again to minimize a weighted least-squares objective function to obtain an optimized set of model parameters. If at the end of a parameter-estimation run the adjusted parameters do not agree with field observations, or the fit between observed and simulated heads and flows is poor, the problem often is related to the conceptual model used as the basis for the groundwaterflow model.

Initial values of hydraulic properties and recharge for the calibration process were based on field observations and knowledge of the aquifer. MODFLOW allows users to input data by zones that are arrays in the model that represent parts of the aquifer with what are believed to be common properties. Horizontal hydraulic conductivity, vertical anistropy, and recharge were represented in the initial model simulations by three zones: Arbuckle-Timbered Hills, Simpson, and postSimpson hydrostratigraphic units. Hydraulic conductivity in the Arbuckle-Timbered Hills hydrostratigraphic unit was initially estimated to be $1 \mathrm{~m} /$ day ( $3.3 \mathrm{ft} /$ day) based on the transmissivity of $12,000 \mathrm{ft}^{2} /$ day from the two-well test discussed in the Aquifer Tests section of this report and an average thickness of the Arbuckle-Simpson hydrostratigraphic unit of 3,396 ft (converted to metric units and rounded). Hydraulic conductivity in the Simpson hydrostratigraphic unit was initially estimated to be one order of magnitude less than the hydraulic conductivity of the Arbuckle-Timbered Hills hydrostratigraphic unit, and hydraulic conductivity in the post-Simpson hydrostratigraphic unit was initially estimated to be two orders of magnitude less than the Arbuckle-Timbered Hills hydrostratigraphic unit. Recharge was initially estimated to be 4.7 inches per year, based on the average estimated by Fairchild and others (1990), where the Arbuckle-Timbered Hills hydrostratigraphic unit was at the land surface, one order of magnitude less for the Simpson and two orders of magnitude less for the post-Simpson. The vertical anistropy was initially estimated to be 1.0 in all hydrostratigraphic units.

The results of the initial parameter-estimation calculations were problematic in that (1) simulated flow in Blue River was about 40 percent less than observed flow, (2) simulated flow in Pennington Creek was about 25 percent greater than observed flow, (3) simulated flow to Buckhorn Creek was 2 orders of magnitude less than observed flow, and (4) the simulated hydraulic conductivity and recharge of the post-Simpson hydrostratigraphic units were large, of similar magnitude as the hydraulic conductivity and recharge computed for the Arbuckle-Timbered Hills hydrostratigraphic unit. Several changes to the model were tested to address these issues.

The only source of water to the Arbuckle-Simpson aquifer is recharge; therefore, errors in the simulated streamflow are because of errors in the recharge rate. Simulations designed to increase simulated flow to Blue River resulted in flow increasing to Pennington Creek, where simulated flow was already greater than flow observed during the August 1995 synoptic measurements. Most of the Pennington Creek subsurface watershed is south of the Sulphur fault, and most of the Blue River subsurface watershed is north of the Sulphur fault. Displacement along the Sulphur fault results in the Cool Creek and McKenzie Hill Formations, of the lower part of the Arbuckle Group, being at the land surface south of the Sulphur fault, and the West Spring Creek and Kindblade Formations, of the upper part of the Arbuckle Group, being at the land surface north of the Sulphur fault. Therefore, the recharge zone for the ArbuckleTimbered Hills zone was divided into two zones separated by the Sulphur fault; recharge north of the Sulphur fault was set to $8.42 \times 10^{-4} \mathrm{~m} / \mathrm{d}\left(2.76 \times 10^{-3} \mathrm{ft} / \mathrm{d}\right.$ or $\left.12.1 \mathrm{in} / \mathrm{yr}\right)$ and recharge south of the Sulphur fault was set to $1.82 \times 10^{-4} \mathrm{~m} / \mathrm{d}(5.99 \times$ $10^{-4} \mathrm{ft} / \mathrm{d}$ or $2.62 \mathrm{in} / \mathrm{yr}$ ). Dividing recharge to the ArbuckleTimbered Hills into two zones improved the match between observed and simulated flows in Blue River and Pennington Creek. After the improvement was noted in the model by assigning different recharge zones north and south of the Sulphur fault, zoning hydraulic conductivity in the ArbuckleTimbered Hills zone north and south of the Sulphur fault was tried, but no improvement was observed in the distribution of simulated heads and flows from that zoning.

Measurements of hydraulic conductivity and recharge for the undifferentiated post-Simpson hydrostratigraphic unit were not found in the literature nor made as part of this study, but as described in the Aquifer Confinement section of this report, the post-Simpson hydrostratigraphic unit functions as a confining layer, and hydraulic conductivity and recharge were expected to be less than the ArbuckleTimbered Hills hydrostratigraphic unit by several orders of magnitude. Therefore, the model was in error when the parameter-estimation process computed hydraulic conductivity and recharge for the post-Simpson hydrostratigraphic unit on the same order of magnitude as the Arbuckle-Timbered Hills hydrostratigraphic unit. Several changes to the model were tested, but the best simulation results were obtained when vertical hydraulic conductivity, input as the vertical anisotropy, in nodes beneath Travertine Creek was increased substantially, and the final value of vertical anisotropy was set to 0.001 (that is, the vertical hydraulic conductivity was 1,000 times greater than the horizontal hydraulic conductivity). Increasing the vertical hydraulic conductivity below Travertine Creek resulted in the parameter-estimation model lowering the horizontal hydraulic conductivity and recharge rate in the post-Simpson hydrostratigraphic unit several orders of magnitude less than in the Arbuckle-Timbered Hills 
hydrostratigraphic unit, as would be expected if the postSimpson hydrostratigraphic unit is functioning as a confining layer.

Several processes could increase the vertical hydraulic conductivity in the aquifer beneath Travertine Creek, including enhanced vertical flow along fractures or faults, enhanced flow in conduits, and hypogene speleogenesis. D.L. Hart, Jr., (U.S. Geological Survey, unpub. data, 1972) ascribes the flow of groundwater to Antelope and Buffalo Springs, which are in the headwaters to Travertine Creek, to flow through the Sulphur fault. Displacement along the Sulphur fault happened prior to the deposition of the post-Simpson hydrostratigraphic unit, and, therefore, the surface expression of the Sulphur fault is masked beneath the post-Simpson hydrostratigraphic unit. The trend of the Sulphur fault, where the fault is not covered by the post-Simpson hydrostratigraphic unit, is toward Travertine Creek. Scheirer and Hosford Scheirer (2006) used geophysical methods to trace the Sulphur fault beneath the post-Simpson hydrostratigraphic unit and estimated that the fault passes about 1,500 ft south of Antelope and Buffalo Springs. Scheirer and Hosford Scheirer (2006) described the faults near Travertine Creek as multiple-strand fault systems, and although the main strand of the Sulphur fault does not pass beneath Travertine Creek, there may be enhanced vertical hydraulic conductivity along fractures associated with the fault. The Sulphur fault is thought to be a high-angle normal fault, as are most major faults in the Arbuckle-Simpson aquifer (see the discussion in the Structural Geology section of this report).

Enhanced flow in conduits near Travertine Creek also could account for the need to increase the vertical hydraulic conductivity at that location. A simulation of the Edwards aquifer in Texas (Scanlon and others, 2001) achieved a better fit between observed and simulated heads by assigning zones of larger hydraulic conductivity near large springs to approximate conduit flow. The large springs in the Edwards aquifer are known to emerge from conduits, but whether the small springs near Travertine Creek are emerging from conduits or fractures is not known.

A particular type of conduit formation process in carbonate rocks is known as "hypogene speleogenesis." The hypogene speleogenesis model postulates certain conditions create a specific type of cave-forming process, or speleogenesis. Hypogenic karst forms in discharge regimes in regional flow systems, especially in confined aquifers (Klimchouk, 2007). Worthington and Ford (1995) associated hypogenic caves with dissolution from sulfuric acid produced by hydrogen sulfide. Klimchouk (2007) stated that hypogenic confined systems evolve to facilitate crossformational hydraulic communication between common aquifers. Klimchouk (2007) also stated that, "Transverse hydraulic communication across lithological and porosity system boundaries, which commonly coincide with major contrasts in water chemistry, gas composition and temperature, is potent enough to drive various disequilibrium and reaction dissolution mechanisms." Travertine Creek flows over a confined part of the Arbuckle-Simpson aquifer, is a discharge area, is on the flow system boundary that coincides with a major contrast in water chemistry, and the discharge produces noticeable amounts of hydrogen sulfide (Christenson and others, 2009). The environment surrounding Travertine Creek would seem to be a good fit for the hypogene speleogenesis model, which enhances vertical hydraulic conductivity. However, determining the exact process that enhances modeled vertical flow beneath Travertine Creek is beyond the scope of this study.

Increasing model vertical hydraulic conductivity beneath Travertine Creek resulted in an improved fit between observed to simulated streamflows on Travertine Creek, and, therefore, other sites along the eastern Arbuckle-Simpson aquifer where enhanced vertical hydraulic conductivity might be affecting the groundwater-flow systems were tested. Buckhorn Creek has some similarities to Travertine Creek. Both creeks are on the western edge of the eastern Arbuckle-Simpson aquifer at the boundary between the freshwater and saline water flow system, and have headwater springs. Increasing the vertical hydraulic conductivity at the model cells underlying Buckhorn Creek improved the match between observed and simulated flow considerably, from two orders of magnitude too low to about the same order of magnitude. (Byrds) Mill Creek and Sheep Creek also have some similarities to Travertine Creek. Both streams are on the eastern edge of the eastern ArbuckleSimpson aquifer at the boundary between the freshwater and saline water flow systems, and have headwater springs. The vertical hydraulic conductivity was increased beneath both streams, and although the error between observed and simulated flow for these streams was not large to begin with, a small reduction in the difference was seen between observed and simulated flow to both streams after increasing the vertical hydraulic conductivity beneath both streams.

The vertical anisotropy was changed to 0.001 along the entire length of the Sulphur fault to investigate if faults are enhancing vertical hydraulic conductivity in the eastern Arbuckle-Simpson aquifer. Increasing the vertical hydraulic conductivity along the fault did not improve the match between simulated and observed head and flow substantially. Because no improvement in model output was observed by increasing vertical hydraulic conductivity along the Sulphur fault, no other simulations were performed with an increased vertical hydraulic conductivity along other faults.

Composite-scaled sensitivities were calculated for every simulation as part of the steady-state calibration process. Composite-scaled sensitivities reflect the total amount of information provided by the observations for the estimation of one parameter (Hill and Tiedeman, 2007). Often composite-scaled sensitivities are used in a comparative manner, whereby a large value indicates a parameter for which the observations provide more information. Models are insensitive to parameters with small composite-scaled sensitivities. Models with parameters with small compositescaled sensitivities can have problems converging. Therefore, for the eastern Arbuckle-Simpson aquifer MODFLOW 
model, parameters with small composite-scaled sensitivities eventually were assigned fixed values and not included in further parameter-estimation computations; fixed values were based on the output from a parameter-estimation computation but often were rounded because the model outcome was insensitive to the result. Parameters that eventually were fixed were the vertical anisotropy of the post-Simpson and Simpson hydrostratigraphic units and the vertical anisotropy of the zones under Buckhorn, Byrds Mill, Travertine, and Sheep Creeks.

Model parameters used in the steady-state calibration are shown in table 17. Simulated flows, which correspond to flows measured during the August 1995 synoptic flow measurement, are shown in table 18. The simulated potentiometric surface, corresponding to the August 1995 potentiometric surface, is shown in figure 32. A map showing the difference between observed and simulated heads at the wells used for calibration is shown on figure 33. Comparison between weighted simulated head observations is shown in figure 34 and weighted simulated residuals (the difference between observed and simulated) is shown in figure 35 . The weighted residuals appear to be random and about equally distributed between positive and negative values.

The simulated steady-state potentiometric-surface map (fig. 32) corresponds closely to the potentiometric-surface map made from the synoptic water-level measurements in August 1995 (fig. 18). The model is calibrated to individual head observations, not to the contoured potentiometric surfaces, so differences and similarities exist between the surfaces. The most obvious difference between the two maps is that the potentiometric-surface map generated from the August 1995 synoptic measurement was interpolated from 151 points (head measurements in wells, and stream and spring elevations); whereas, the simulated potentiometric surface was interpolated to all the active cells in the upper layer of the model, or 25,061 points. The map created from the synoptic measurements interpolates over long distances because of few points, and the interpolated contours are not influenced by all hydrologic features shown on the map. For example, contours on the map made from the synoptic measurements are interpolated across Blue River as if the stream did not exist (for example, on fig. 18 the $1,040-\mathrm{ft}$ contour at about N34 $30^{\prime}$ latitude, W96 $40^{\prime}$ longitude). The MODFLOW model calculates a head at every active cell in the model, so that the interpolated contours continue to the edge of the map, which is the edge of the model domain. At the edge of the simulated potentiometricsurface map, contours are always perpendicular to the boundary because the boundary is simulated as no flow.

The calibrated steady-state model simulation reproduces the major features observable in the August 1995 potentiometric-surface map: (1) the potentiometric surface in the Arbuckle-Timbered Hills hydrostratigraphic unit slopes downward from a high of more than $1,160 \mathrm{ft}$ at the northwestern extent of the outcrop of the Arbuckle-Timbered

Table 17. Eastern Arbuckle-Simpson aquifer, south-central Oklahoma, MODFLOW model parameters from the steady-state calibration.

[Transmissivity calculated by using saturated thickness derived from hydrogeologic model and interpolated potentiometric surface from water-level measurements made in August 1995; *, the full thickness of the Simpson geologic unit is not in the model domain]

\begin{tabular}{|c|c|c|c|c|c|}
\hline Parameter & Model hydrostratigraphic unit & Value & Units & Value & Units \\
\hline \multirow[t]{4}{*}{ Recharge } & Post-Simpson & $1.10 \times 10^{-7}$ & meter/day & $3.60 \times 10^{-7}$ & foot/day \\
\hline & Simpson & $2.73 \times 10^{-5}$ & meter/day & $8.94 \times 10^{-5}$ & foot/day \\
\hline & $\begin{array}{l}\text { Arbuckle-Timbered Hills (north } \\
\text { of Sulphur fault) }\end{array}$ & $8.42 \times 10^{-4}$ & meter/day & $2.76 \times 10^{-3}$ & foot/day \\
\hline & $\begin{array}{l}\text { Arbuckle-Timbered Hills (south } \\
\text { of Sulphur fault) }\end{array}$ & $1.82 \times 10^{-4}$ & meter/day & $5.99 \times 10^{-4}$ & foot/day \\
\hline \multirow{3}{*}{$\begin{array}{l}\text { Hydraulic } \\
\text { conductivity }\end{array}$} & Post-Simpson & $3.36 \times 10^{-4}$ & meter/day & $1.10 \times 10^{-3}$ & foot/day \\
\hline & Simpson & $1.19 \times 10^{-1}$ & meter/day & $3.90 \times 10^{-1}$ & foot/day \\
\hline & Arbuckle-Timbered Hills & $1.01 \times 10^{0}$ & meter/day & $3.30 \times 10^{0}$ & foot/day \\
\hline \multirow[t]{4}{*}{ Vertical anisotropy } & Post-Simpson & $5.00 \times 10^{2}$ & ratio (unitless) & & \\
\hline & Simpson & $2.00 \times 10^{3}$ & ratio (unitless) & & \\
\hline & Arbuckle-Timbered Hills & $5.97 \times 10^{0}$ & ratio (unitless) & & \\
\hline & $\begin{array}{l}\text { Arbuckle-Timbered Hills (near } \\
\text { springs) }\end{array}$ & $1.00 \times 10^{-3}$ & ratio (unitless) & & \\
\hline \multirow{2}{*}{$\begin{array}{l}\text { Transmissivity } \\
\text { (average) }\end{array}$} & Simpson* & $1.64 \times 10^{1}$ & meter $^{2} /$ day & $1.77 \times 10^{2}$ & foot $^{2} /$ day \\
\hline & Arbuckle-Timbered Hills & $1.03 \times 10^{3}$ & meter $^{2} /$ day & $1.11 \times 10^{4}$ & foot $^{2} /$ day \\
\hline
\end{tabular}


Table 18. Simulated streamflows compared to streamflow measurements on August 14, 1995.

$\left[\mathrm{ft}^{3} / \mathrm{s}\right.$, cubic feet per second $]$

\begin{tabular}{lcc}
\hline Stream observation & $\begin{array}{c}\text { Observed } \\
\text { streamflow }\left(\mathbf{f t}^{3} / \mathbf{s}\right)\end{array}$ & $\begin{array}{c}\text { Simulated } \\
\text { streamflow }\left(\mathbf{f t}^{3} / \mathbf{s}\right)\end{array}$ \\
\hline Blue River & 82.8 & 73.57 \\
Buckhorn Creek & 5.28 & 2.87 \\
Byrds Mill Spring & 21 & 14.84 \\
Delaware Creek & 1.92 & 2.03 \\
Mill Creek & 6.6 & 5.93 \\
Pennington Creek & 24.2 & 29.02 \\
Rock Creek & 15 & 18.19 \\
Sheep Creek & 4.91 & 6.01 \\
Total & 161.71 & 152.45 \\
\hline
\end{tabular}

Hills hydrostratigraphic unit to low elevations along the southeastern edge of the aquifer outcrop; (2) horizontal hydraulic gradients are larger in the Simpson than in the ArbuckleTimbered Hills hydrostratigraphic unit, including in the Sulphur syncline, reflecting the smaller hydraulic conductivity of that hydrostratigraphic unit; and (3) a potentiometric high is visible in the large outcrop of Simpson Group in the eastern part of the aquifer at about $\mathrm{N} 34^{\circ} 31^{\prime}$ latitude, W96 $37^{\prime}$ longitude.

A groundwater-model volumetric budget, commonly referred to as a "water budget," is a tabulation of groundwater flow into or out of the simulated aquifer. The water budget for the eastern Arbuckle-Simpson aquifer under steady-state conditions is $158.11 \mathrm{ft}^{3} / \mathrm{s}$ of recharge and $158.11 \mathrm{ft}^{3} / \mathrm{s}$ of discharge to drains. Simulated streamflow for the steady-state model of $152.45 \mathrm{ft}^{3} / \mathrm{s}$ is shown in table 18 ; the difference, $5.66 \mathrm{ft}^{3} / \mathrm{s}$, is the difference between simulated streamflow as discharge to drains for the entire model and simulated streamflow for streams with observed streamflow.

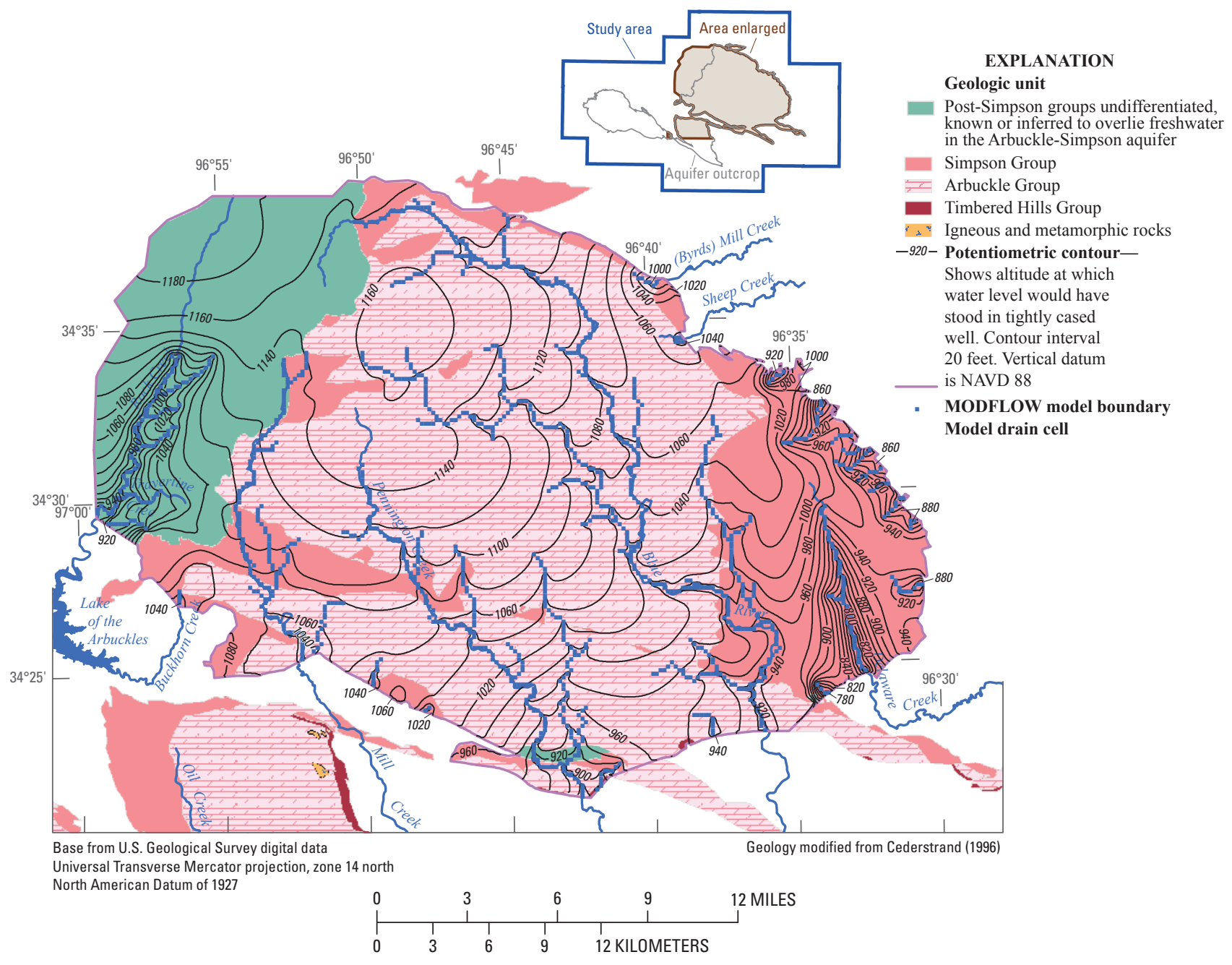

Figure 32. Simulated steady-state potentiometric surface in layer 1 of the eastern Arbuckle-Simpson aquifer, south-central Oklahoma, that corresponds to the August 1995 synoptic measurement. 


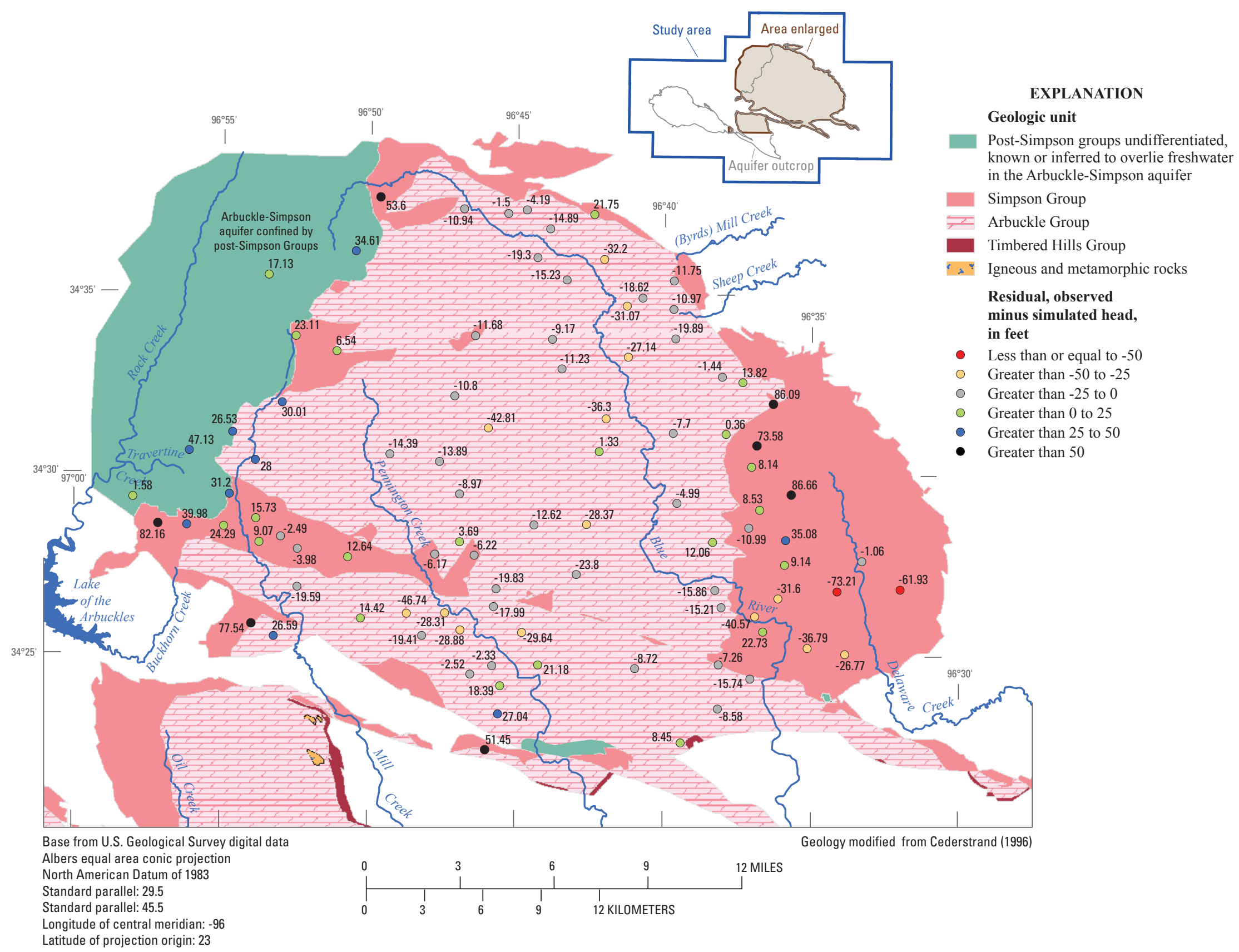

Figure 33. Comparison between observed and simulated heads in the eastern Arbuckle-Simpson aquifer, south-central Oklahoma, steady-state MODFLOW model. 


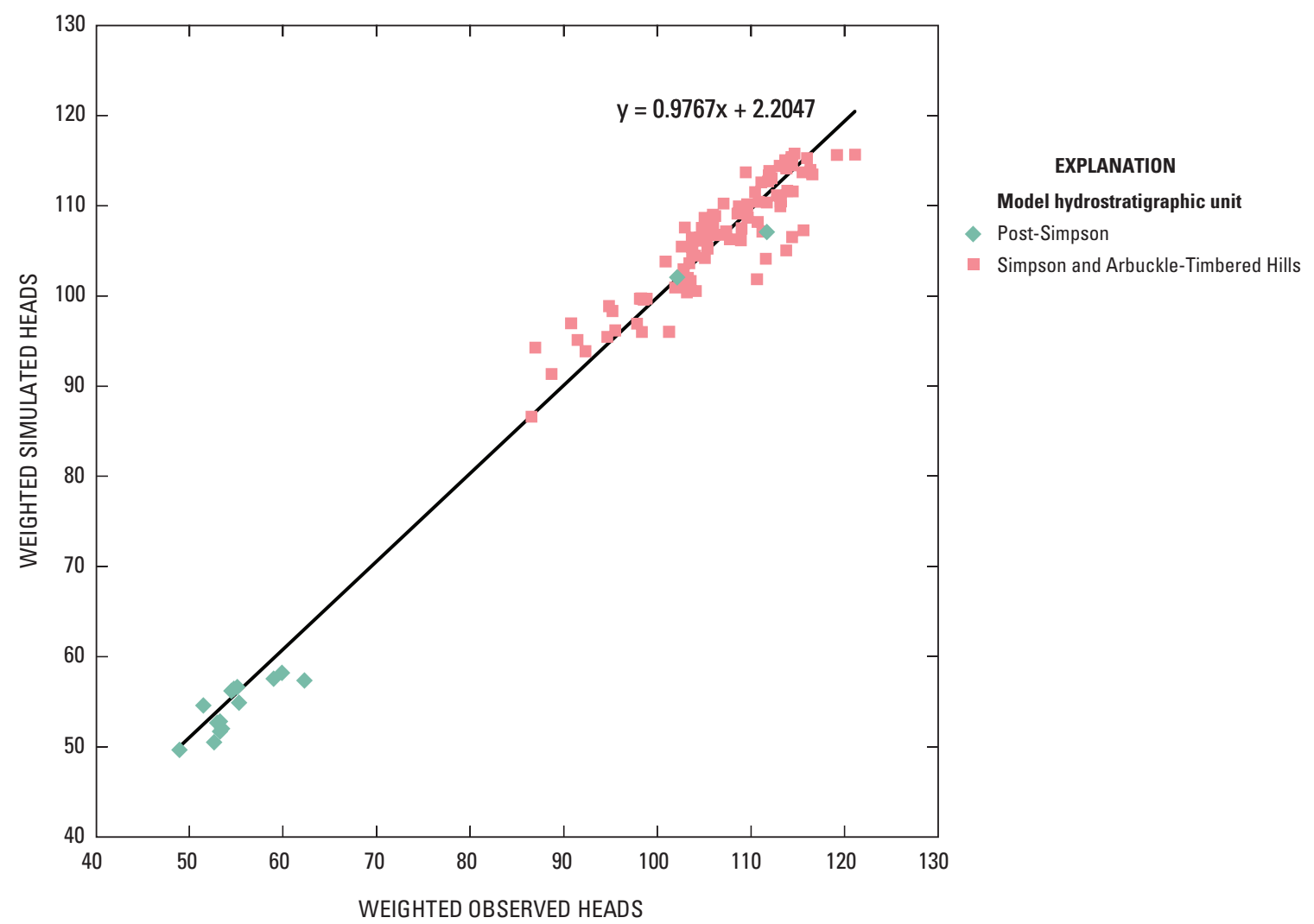

Figure 34. Comparison of weighted observed to weighted simulated head observations from the steady-state MODFLOW model corresponding to the August 1995 synoptic measurements.

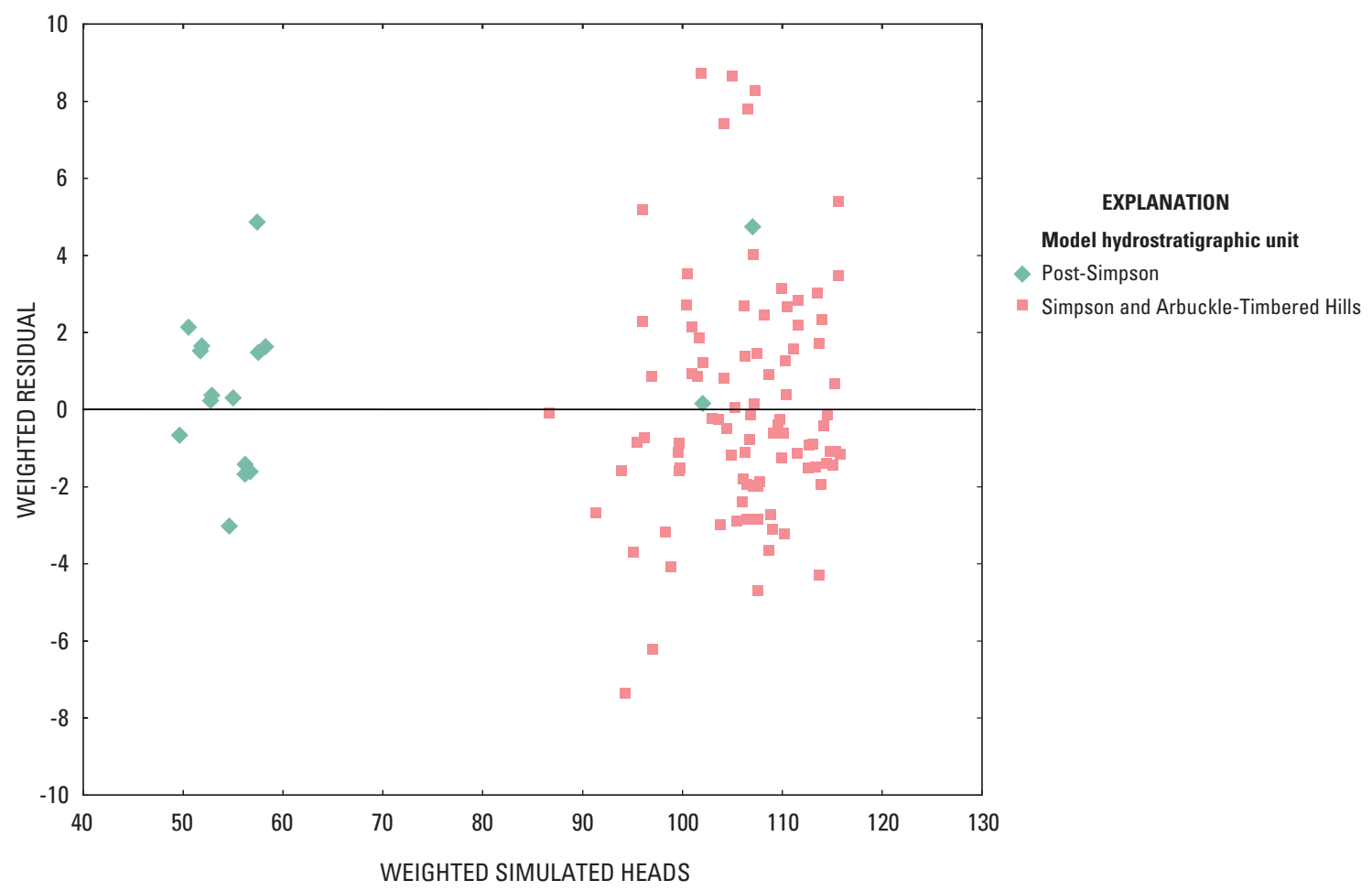

Figure 35. Weighted residual and weighted simulated head observations for the eastern Arbuckle-Simpson aquifer, south-central Oklahoma, MODFLOW model. 


\section{Transient Model Calibration}

The eastern Arbuckle-Simpson aquifer MODFLOW model was calibrated to transient conditions, in this case for the 5-water-year time period starting October 1, 2003, through September 30, 2008, corresponding to water years 2004 through 2008. That period was selected because data from the streamgages that were installed at the beginning of the study became available October 1, 2003. The transient calibration process starts from a steady-state calibration. The eastern Arbuckle-Simpson aquifer MODFLOW model was calibrated to a steady-state condition corresponding to August 1995, more than 8 years prior to the start of the October 1, 2003, transient calibration period. Therefore, a second, limited steady-state simulation was performed to correspond to October 1, 2003. However, only a few head and flow observations were available on October 1, 2003. Flow observations were available for four streamgages (Blue River near Connerville, Oklahoma, Byrds Mill Spring, Pennington Creek near Reagan, Oklahoma, and Rock Creek near Sulphur, Oklahoma) and head observations were available from three observation wells equipped with continuous data loggers. The purpose of this limited steady-state simulation was not for calibration but rather to adjust the potentiometric surface and head in the aquifer to correspond to October 1, 2003. Therefore, only recharge was adjusted in the simulation, and the hydraulic properties were unchanged from the August 1995 steady-state calibration. Recharge was adjusted by trial and error to minimize the error between observed and computed streamflow at the Blue River near Connerville, Oklahoma, and the Pennington Creek near Reagan,

Oklahoma, streamgages.

The heads computed from the October 1, 2003, steadystate simulation were used as the starting heads for the transient calibration. Specific storage was set to $0.000008 / \mathrm{m}$ $(0.0000024 / \mathrm{ft})$ for all hydrostratigraphic units, based on the 0.008 storage coefficient calculated by Fairchild and others (1990), which is within the range of storage coefficients calculated by regional methods for this study (see the Regional Methods To Determine Storage Coefficient section of this report), and assuming the aquifer was $1,000 \mathrm{~m}(3,281 \mathrm{ft})$ thick (the average saturated thickness of the Arbuckle-Timbered Hills hydrostratigraphic unit in the model domain was 1,026 $\mathrm{m}(3,366 \mathrm{ft})$, as computed from the data exported from the geologic framework model).

Recharge for all model cells corresponding to the outcrop of the Arbuckle-Timbered Hills hydrostratigraphic unit north of the Sulphur fault initially was set to the daily recharge from analysis of the streamflow data from the Blue River near Connerville, Oklahoma, streamgage and recharge for all model cells corresponding to the outcrop of the ArbuckleTimbered Hills hydrostratigraphic unit south of the Sulphur fault initially was set to the daily recharge from analysis of the streamflow data from the Pennington Creek near Reagan, Oklahoma, streamgage. Streamgages were not available where the subsurface watershed was exclusively or largely on the
Simpson Group or post-Simpson hydrostratigraphic units. Recharge for model cells that correspond to the outcrop of the Simpson and post-Simpson hydrostratigraphic units were set to the fraction of the recharge for the Arbuckle-Timbered Hills hydrostratigraphic unit north of the Sulphur fault from the steady-state calibration. That fraction was 0.362 for the Simpson hydrostratigraphic unit and 0.000125 for the postSimpson hydrostratigraphic unit; that is, if the recharge for the Arbuckle-Timbered Hills hydrostratigraphic unit north of the Sulphur fault was 1 inch for a specific day, a daily recharge of 0.362 inch was applied to the Simpson hydrostratigraphic unit and 0.000125 inch was applied to the post-Simpson hydrostratigraphic unit for that same day.

Calibration of the transient model was accomplished by running the model with 1-day stress periods for 5 water years, the 1,827-day period (including leap days) from October 1, 2003, to September 30, 2008. MODFLOW uses the term "stress period" to mean a period of time during which stresses are constant, and stress periods can be divided into time steps, which are subdivisions of stress periods. One-day stress periods were used because daily recharge was available from the RORA recharge analysis (see the Recharge subsection in the Groundwater section of this report). Subdividing the 1-day stress periods into time steps of less than 1 day did not improve model convergence or result in changes in simulated heads and flows, so the transient calibration was performed with one time step per 1-day stress period. Groundwater withdrawals were set to a daily rate based on the reported monthly total water use received from the OWRB, assuming that the well pumped at a constant rate that would result in the total monthly withdrawal being equal to the reported monthly water use.

Model simulations were run for the 5 water years, and simulated daily discharge to the drains that represent streams and springs was saved to an external binary file. The external file was processed by using the ZONEBUDGET program (Harbaugh, 1990), which reads the binary file and computes flows based on user-defined zones. For the eastern Arbuckle-Simpson aquifer MODFLOW model, zones were individual streams, simulated as drains. Daily simulated groundwater discharge to drains was computed for Blue River, Buckhorn Creek, Byrds Mill Spring, Delaware Creek, Mill Creek, Pennington Creek, Rock Creek, Sheep Creek, Travertine Creek, and a separate zone for all other groundwater discharge.

The MODFLOW-simulated discharge to drains corresponds to the groundwater component of streamflow. Streamflow consists of a groundwater component (base flow) and runoff. As described in the Streamflow section of this report, the groundwater and runoff components of streamflow were calculated for gaged streamflows at the Blue River near Connerville, Oklahoma, and the Pennington Creek near Reagan, Oklahoma, streamgages by using the PART program (Rutledge, 1998). The MODFLOW-simulated discharge to drains is equivalent to the groundwater component of flow calculated by the PART program; to calculate the daily 
flow at Blue River and Pennington Creek, the daily runoff component computed by the PART program was added to the MODFLOW-simulated groundwater discharge to drains for Blue River and Pennington Creek. The total flows were summed and compared to the sum of the gaged discharges at the Blue River near Connerville, Oklahoma, and Pennington Creek near Reagan, Oklahoma, streamgages as a measure of the total amount of water that flowed past each streamgage for the 5-water-year period.

Total simulated flows did not match observed streamflows at the Blue River near Connerville, Oklahoma, and the Pennington Creek near Reagan, Oklahoma, streamgages in initial simulations of the 5-water-year period. The hydrographs of the Blue River near Connerville, Oklahoma, and the Pennington Creek near Reagan, Oklahoma, streamgages show frequent small rises in streamflow, even in the absence of precipitation in the watershed. These rises could be caused by several factors. Modern pressure transducers used to measure stage, from which discharge is computed, have some output noise. The streamgage at Pennington Creek near Reagan, Oklahoma, is downstream from a fish hatchery, which routes streamflow through ponds and periodically changes the amount of water diverted through the hatchery. The RORA program computes daily recharge in response to each of these small increases in streamflow, many of which probably do not represent additional recharge applied to the aquifer. A recording rain gage was installed in the Blue River watershed during the course of the study, but data from that rain gage were not available for the entire 5-water-year period. No recording rain gage data were available in the Pennington Creek watershed.

Estimates of daily precipitation for Blue River and Pennington Creek were derived from NEXRAD radar data and supplied to the study (B. Vieux, University of Oklahoma, written commun., 2008). Radar-derived precipitation in the Blue River and Pennington Creek watersheds was compared to the daily recharge computed from the streamflow data collected at the Blue River near Connerville, Oklahoma, and the Pennington Creek near Reagan, Oklahoma, streamgages. If no precipitation fell in the watershed (based on the NEXRAD radar) for any day for which recharge was calculated, no recharge was applied as input to the MODFLOW model.

Daily recharge was multiplied by a factor, constant for the entire 5-water-year period, to adjust total simulated streamflow (MODFLOW-simulated base flow plus the runoff component from the PART program) for the 5-water-year period to obtain a match to the measured streamflows at the Blue River near Connerville, Oklahoma, and the Pennington Creek near Reagan, Oklahoma, streamgages. Adjusting the recharge only modifies the MODFLOW-simulated base flow; the runoff component is fixed at the amount determined by the PART program. The recharge factor, determined from the model calibration, was 0.931422 times the daily recharge computed by the RORA program from streamflow measured at the Blue River near Connerville, Oklahoma, streamgage for recharge applied to the Arbuckle-Timbered
Hills hydrostratigraphic unit north of the Sulphur fault, and 0.809964 times the daily recharge computed by the RORA program from streamflow measured at the Pennington Creek near Reagan, Oklahoma, streamgage for recharge applied to the Arbuckle-Timbered Hills hydrostratigraphic unit south of the Sulphur fault. Many issues could be the cause of the need for these recharge factors. One of the primary causes was thought to be the uncertainty in the size of the subsurface watershed used to calculate the recharge rate by the RORA program (see the Subsurface Watersheds section of this report). The RORA program calculates the total volume (in units of length cubed) of a recharge period based on the streamflow hydrograph, and calculates the recharge depth (in units of length) for the period by dividing the recharge volume by the area of the watershed. The area of each subsurface watershed in the eastern Arbuckle-Simpson aquifer was defined by a few points and the error in computing the size of each basin could be the cause of the need for the recharge factors. Other possible causes for the need for the recharge factor could be errors in the model calibration, the daily recharge computed by the RORA program, or the discharge computed at the streamgages.

Recharge computed by the RORA program is based on streamflow-gaging data and the area of the subsurface watershed upstream from the streamgage. The recharge rate was applied to MODFLOW recharge zones (fig. 31) that are based on the hydrostratigraphic unit at the land surface, and recharge to the Simpson and post-Simpson hydrostratigraphic units were computed as a fraction of the recharge rate to the Arbuckle-Timbered Hills hydrostratigraphic unit north of the Sulphur fault. Area-weighted annual recharge rates applied to the model domain averaged 5.58 inches (142 millimeters [mm]) per year for water years 2004-8, and ranged from 2.57 inches $(65.3 \mathrm{~mm})$ in water year 2006 to 11.61 inches (295 mm) in water year 2007 (table 19). The area-weighted applied rates are lower than the recharge rates computed directly from streamgage data using the RORA program (table 9) because the recharge rates are lower for areas overlain by the Simpson and post-Simpson hydrostratigraphic units.

Total streamflow for the 5-water-year period measured at the Blue River near Connerville, Oklahoma, streamgage was 336,712 acre-ft and the total simulated flow (MODFLOWsimulated groundwater discharge plus PART-computed runoff) was 336,946 acre-ft. Total streamflow for the

Table 19. Area-weighted average annual recharge for the eastern Arbuckle-Simpson aquifer, south-central Oklahoma, MODFLOW model for water years 2004-8.

\begin{tabular}{|c|c|c|c|c|c|c|}
\hline & \multicolumn{5}{|c|}{ Water year } & \multirow[b]{2}{*}{$\begin{array}{c}\text { 5-year } \\
\text { average }\end{array}$} \\
\hline & 2004 & 2005 & 2006 & 2007 & 2008 & \\
\hline $\begin{array}{l}\text { Recharge } \\
\text { (inches) }\end{array}$ & 3.28 & 7.57 & 2.57 & 11.61 & 2.85 & 5.58 \\
\hline
\end{tabular}


5-water-year period measured at the Pennington Creek near Reagan, Oklahoma, streamgage was 155,720 acre-ft and the total simulated streamflow was 154,699 acre-ft. Monthly gaged and simulated streamflows are shown on figure 36 for the Blue River near Connerville, Oklahoma, streamgage and figure 37 for the Pennington Creek near Reagan,

Oklahoma, streamgage.

Although the transient model calibration was primarily based on streamflows in Blue River and Pennington Creek, the model also reproduces head response in observation wells. Comparison between observed average daily head and simulated median monthly heads in observation wells is shown in figure 38 . Daily head observations were compared to simulated median monthly head because the eastern Arbuckle-Simpson MODFLOW model does not simulate the

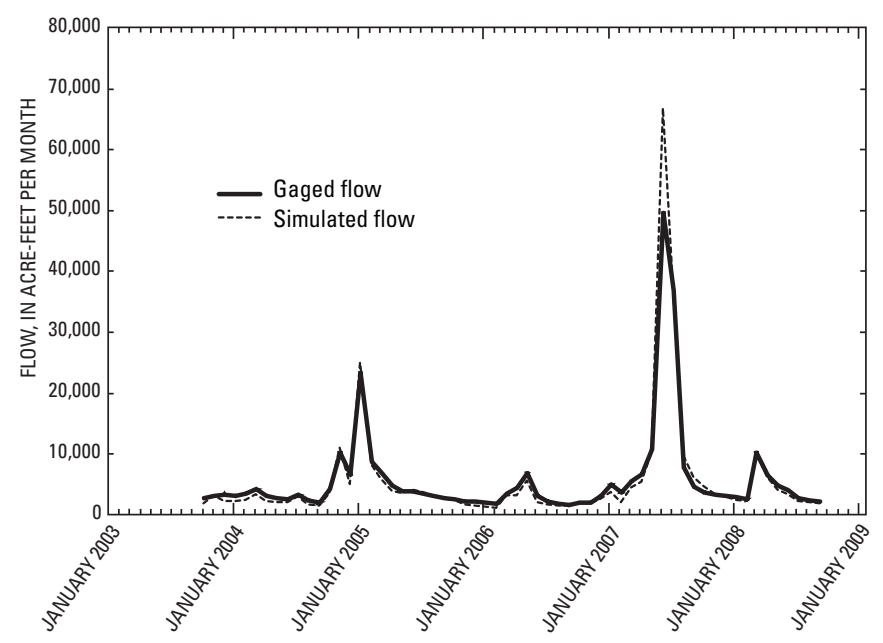

Figure 36. Monthly gaged streamflow compared to monthly simulated streamflow (MODFLOW-simulated groundwater discharge plus PART-computed runoff) for Blue River near Connerville, Oklahoma, for water years 2004-8.

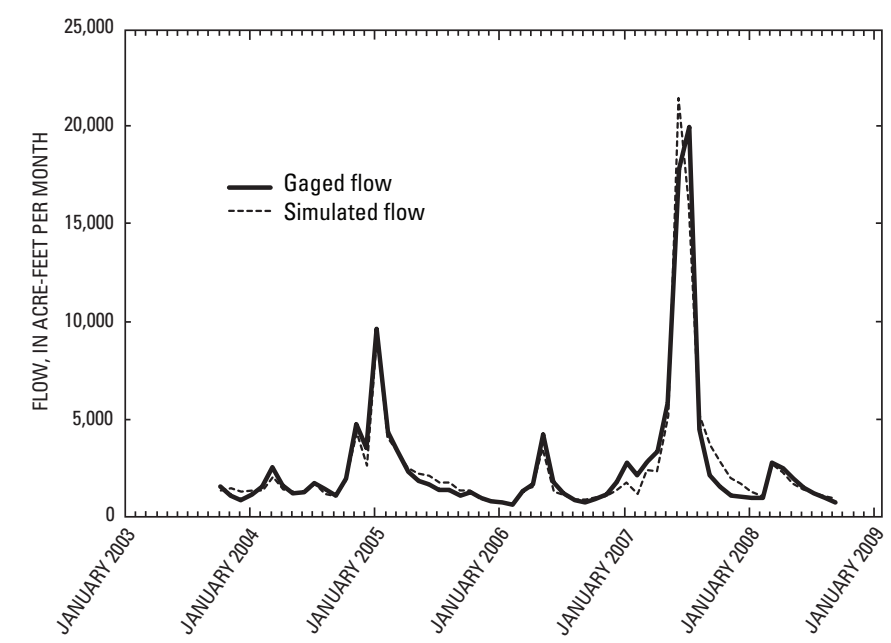

Figure 37. Monthly gaged streamflow compared to monthly simulated streamflow (MODFLOW-simulated groundwater discharge plus PART-computed runoff) for Pennington Creek near Reagan, Oklahoma, for water years 2004-8. unsaturated zone; therefore, recharge in the model arrives at the water table instantaneously, which causes a short-term, unrealistic increase in simulated head. The actual recharge in the aquifer is delayed and takes some finite period of time as the recharge moves through the unsaturated zone. Simulated head responses tend to reproduce the general character but do not exactly match observed head responses. The study objectives emphasize modeling streamflow, not heads, so that the differences between observed and simulated water levels were considered to be acceptable.

\section{Water Budget}

A water budget was computed for the eastern ArbuckleSimpson transient MODFLOW model on a monthly basis (the model uses daily time steps, so daily data are summed to produce monthly totals) and is shown in table 20 . The recharge component of the water budget, subdivided by the model recharge zones, is shown in figure 39 . The base-flow component of discharge to individual streams is shown in figure 40. Base flow represents the total groundwater discharge to every stream (modeled as a drain) in the model. The terms "input" and "output" refer to water coming into or going out of the groundwater-flow system. MODFLOW considers groundwater in storage not to be part of the groundwater-flow system, which may seem counterintuitive. Storage input and output reflect the potentiometric surface rising and falling, and, therefore, water moving into and out of storage. As the potentiometric surface falls in the absence of recharge, MODFLOW considers water to be added to the groundwaterflow system from storage, just as recharge is added to the groundwater-flow system. For example, in November 2005, the water budget shows little recharge. The monthly hydrograph at the Blue River near Connerville, Oklahoma, streamgage (fig. 36) shows streamflow declining during that month. The water budget for that month (table 20) shows only 243 acre-ft of water were added (listed in the Input column in table 20) to the groundwater-flow system from recharge and 5,583 acre-ft were added to the groundwater-flow system as storage input, meaning water that came out of storage as the potentiometric surface declined. Therefore, the model computed that a total of 5,826 acre- $\mathrm{ft}$ of water were added to the eastern Arbuckle-Simpson aquifer during that month, which was balanced by 5,320 acre-ft discharging as base flow, plus 281 acre-ft discharging to wells, plus 226 acre-ft leaving the groundwater-flow system as storage output, meaning water that entered storage as the potentiometric surface rose in response to the small amount of recharge during that month.

The water budget shows that water added to and subtracted from the groundwater-flow system are equal, within the limits of rounding error. Monthly means for storage input (11,555 acre-ft) and recharge (9,592 acre-ft) for the 5-wateryear period of simulation are balanced by monthly means of storage output (11,467 acre-ft), wells (464 acre-ft), and base flow $(9,217$ acre-ft). 

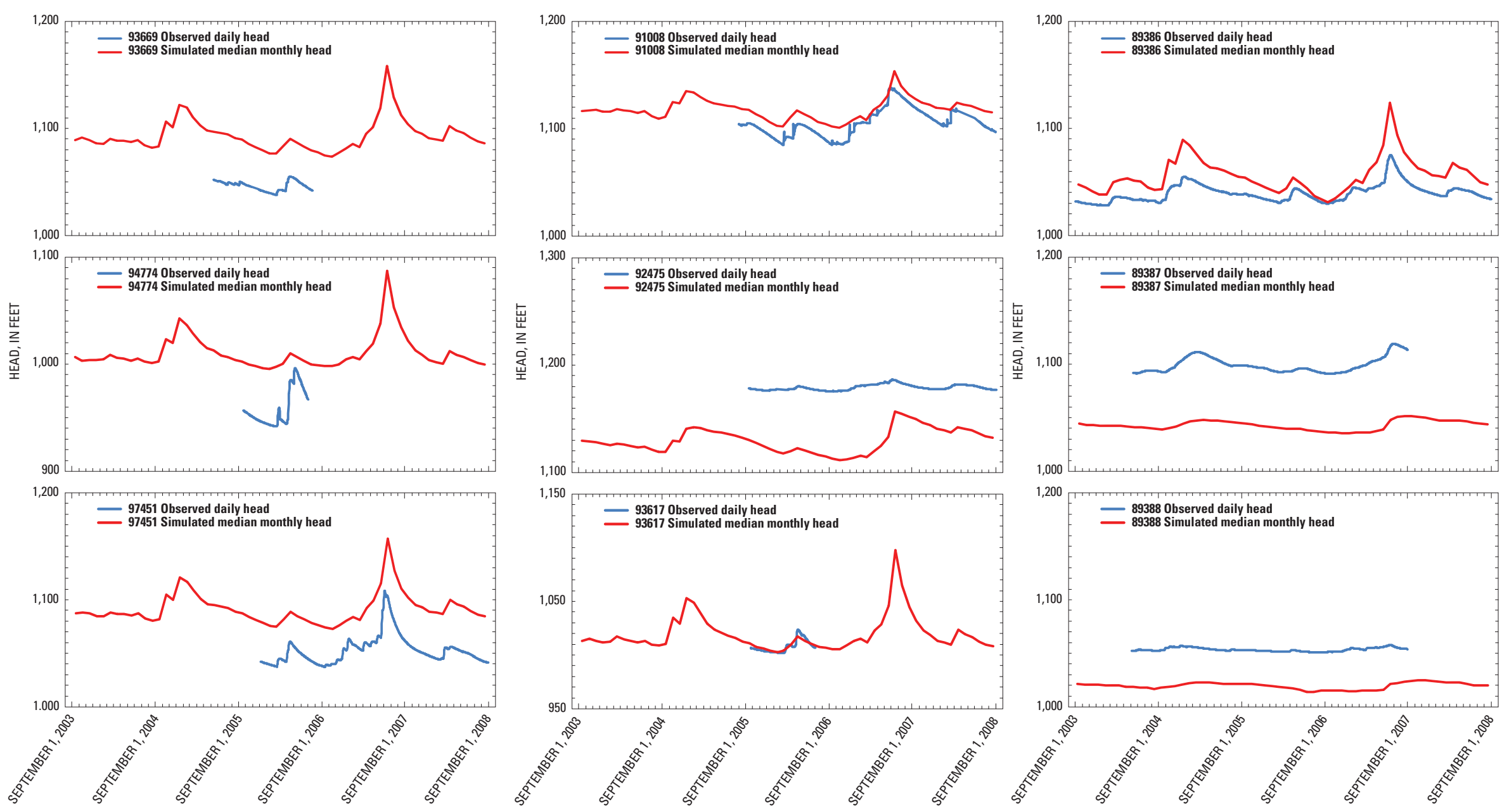

Figure 38. Comparison of observed and simulated heads for wells equipped with instruments to measure water levels continuously in the eastern Arbuckle-Simpson aquifer, south-central Oklahoma, for water years 2004-8. 

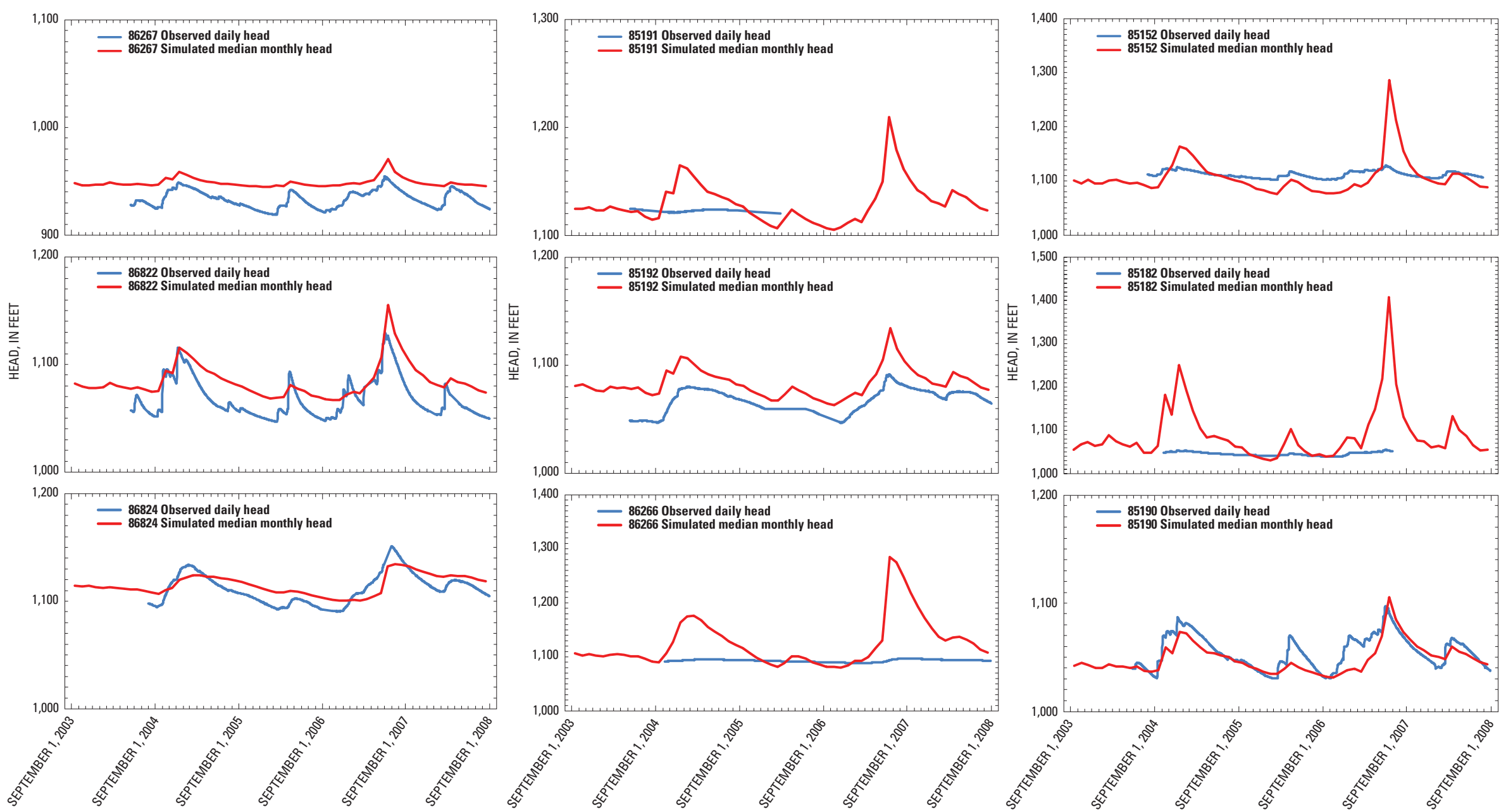

Figure 38. Comparison of observed and simulated heads for wells equipped with instruments to measure water levels continuously in the eastern Arbuckle-Simpson aquifer, south-central Oklahoma, for water years 2004-8.-Continued 
Table 20. Monthly water budget for the eastern Arbuckle-Simpson aquifer, south-central Oklahoma, MODFLOW model.

\begin{tabular}{|c|c|c|c|c|c|c|c|}
\hline \multirow[b]{2}{*}{ Year } & \multirow[b]{2}{*}{ Month } & \multirow[b]{2}{*}{ Water year } & \multicolumn{2}{|c|}{ Input } & \multicolumn{3}{|c|}{ Output } \\
\hline & & & $\begin{array}{c}\text { Storage } \\
\text { (acre-feet) }\end{array}$ & $\begin{array}{c}\text { Recharge } \\
\text { (acre-feet) }\end{array}$ & $\begin{array}{c}\text { Storage } \\
\text { (acre-feet) }\end{array}$ & $\begin{array}{c}\text { Wells } \\
\text { (acre-feet) }\end{array}$ & $\begin{array}{l}\text { Base flow } \\
\text { (acre-feet) }\end{array}$ \\
\hline 2003 & 10 & 2004 & 7,152 & 556 & 385 & 860 & 6,463 \\
\hline 2003 & 11 & 2004 & 10,939 & 12,247 & 14,775 & 919 & 7,493 \\
\hline 2003 & 12 & 2004 & 7,082 & 3,544 & 3,392 & 916 & 6,318 \\
\hline 2004 & 1 & 2004 & 7,158 & 5,080 & 5,161 & 885 & 6,193 \\
\hline 2004 & 2 & 2004 & 7,566 & 7,261 & 7,863 & 821 & 6,143 \\
\hline 2004 & 3 & 2004 & 9,574 & 11,288 & 12,798 & 265 & 7,799 \\
\hline 2004 & 4 & 2004 & 6,484 & 6,046 & 5,711 & 262 & 6,558 \\
\hline 2004 & 5 & 2004 & 6,835 & 4,020 & 4,071 & 323 & 6,461 \\
\hline 2004 & 6 & 2004 & 6,401 & 4,600 & 4,562 & 452 & 5,987 \\
\hline 2004 & 7 & 2004 & 7,824 & 7,771 & 8,215 & 564 & 6,815 \\
\hline 2004 & 8 & 2004 & 6,080 & 1,434 & 1,304 & 603 & 5,607 \\
\hline 2004 & 9 & 2004 & 5,480 & 3,875 & 3,561 & 562 & 5,233 \\
\hline 2004 & 10 & 2005 & 7,953 & 8,258 & 9,469 & 623 & 6,119 \\
\hline 2004 & 11 & 2005 & 22,599 & 34,748 & 43,417 & 275 & 13,655 \\
\hline 2004 & 12 & 2005 & 13,777 & 11,153 & 13,508 & 260 & 11,162 \\
\hline 2005 & 1 & 2005 & 37,178 & 45,805 & 58,557 & 264 & 24,162 \\
\hline 2005 & 2 & 2005 & 15,432 & 19,706 & 18,999 & 254 & 15,886 \\
\hline 2005 & 3 & 2005 & 13,719 & 7,626 & 7,362 & 286 & 13,697 \\
\hline 2005 & 4 & 2005 & 10,507 & 3,386 & 3,142 & 270 & 10,481 \\
\hline 2005 & 5 & 2005 & 8,895 & 4,777 & 4,103 & 294 & 9,276 \\
\hline 2005 & 6 & 2005 & 9,955 & 5,908 & 6,517 & 332 & 9,014 \\
\hline 2005 & 7 & 2005 & 9,297 & 6,840 & 7,280 & 347 & 8,511 \\
\hline 2005 & 8 & 2005 & 8,191 & 6,294 & 6,099 & 517 & 7,868 \\
\hline 2005 & 9 & 2005 & 6,706 & 1,741 & 1,683 & 315 & 6,448 \\
\hline 2005 & 10 & 2006 & 6,689 & 4,636 & 4,415 & 348 & 6,561 \\
\hline 2005 & 11 & 2006 & 5,583 & 243 & 226 & 281 & 5,320 \\
\hline 2005 & 12 & 2006 & 5,440 & 2,012 & 1,868 & 380 & 5,204 \\
\hline 2006 & 1 & 2006 & 5,187 & 1,062 & 1,032 & 449 & 4,767 \\
\hline 2006 & 2 & 2006 & 4,496 & 319 & 288 & 445 & 4,083 \\
\hline 2006 & 3 & 2006 & 10,312 & 14,815 & 18,090 & 654 & 6,382 \\
\hline 2006 & 4 & 2006 & 7,271 & 8,144 & 8,954 & 646 & 5,815 \\
\hline 2006 & 5 & 2006 & 13,578 & 10,878 & 15,486 & 388 & 8,582 \\
\hline 2006 & 6 & 2006 & 6,674 & 3,486 & 3,319 & 606 & 6,234 \\
\hline 2006 & 7 & 2006 & 6,123 & 2,009 & 1,726 & 861 & 5,545 \\
\hline 2006 & 8 & 2006 & 6,024 & 2,670 & 2,655 & 1,051 & 4,988 \\
\hline 2006 & 9 & 2006 & 5,564 & 2,722 & 2,652 & 979 & 4,656 \\
\hline 2006 & 10 & 2007 & 6,019 & 4,050 & 4,396 & 955 & 4,718 \\
\hline 2006 & 11 & 2007 & 5,004 & 5,213 & 4,979 & 566 & 4,672 \\
\hline 2006 & 12 & 2007 & 7,544 & 10,037 & 11,436 & 601 & 5,545 \\
\hline 2007 & 1 & 2007 & 11,565 & 10,695 & 14,993 & 314 & 6,954 \\
\hline 2007 & 2 & 2007 & 6,465 & 5,604 & 5,951 & 272 & 5,845 \\
\hline 2007 & 3 & 2007 & 5,925 & 14,271 & 13,153 & 272 & 6,770 \\
\hline 2007 & 4 & 2007 & 14,367 & 9,340 & 15,118 & 281 & 8,307 \\
\hline
\end{tabular}


Table 20. Monthly water budget for the eastern Arbuckle-Simpson aquifer, south-central Oklahoma, MODFLOW model.—Continued

\begin{tabular}{|c|c|c|c|c|c|c|c|}
\hline \multirow[b]{2}{*}{ Year } & \multirow[b]{2}{*}{ Month } & \multirow[b]{2}{*}{ Water year } & \multicolumn{2}{|c|}{ Input } & \multicolumn{3}{|c|}{ Output } \\
\hline & & & $\begin{array}{c}\text { Storage } \\
\text { (acre-feet) }\end{array}$ & $\begin{array}{c}\text { Recharge } \\
\text { (acre-feet) }\end{array}$ & $\begin{array}{c}\text { Storage } \\
\text { (acre-feet) }\end{array}$ & $\begin{array}{c}\text { Wells } \\
\text { (acre-feet) }\end{array}$ & $\begin{array}{l}\text { Base flow } \\
\text { (acre-feet) }\end{array}$ \\
\hline 2007 & 5 & 2007 & 16,953 & 30,458 & 34,494 & 294 & 12,623 \\
\hline 2007 & 6 & 2007 & 95,268 & 149,306 & 193,194 & 336 & 51,044 \\
\hline 2007 & 7 & 2007 & 43,734 & 0 & 10,253 & 364 & 33,117 \\
\hline 2007 & 8 & 2007 & 23,490 & 0 & 2,288 & 412 & 20,789 \\
\hline 2007 & 9 & 2007 & 15,817 & 760 & 1,689 & 329 & 14,559 \\
\hline 2007 & 10 & 2008 & 12,393 & 1,764 & 1,999 & 321 & 11,837 \\
\hline 2007 & 11 & 2008 & 9,719 & 2,114 & 2,465 & 283 & 9,085 \\
\hline 2007 & 12 & 2008 & 8,603 & 2,808 & 2,703 & 272 & 8,436 \\
\hline 2008 & 1 & 2008 & 7,428 & 1,680 & 1,783 & 258 & 7,067 \\
\hline 2008 & 2 & 2008 & 6,663 & 3,366 & 3,407 & 268 & 6,354 \\
\hline 2008 & 3 & 2008 & 12,879 & 16,734 & 20,084 & 259 & 9,270 \\
\hline 2008 & 4 & 2008 & 12,489 & 12,998 & 14,838 & 287 & 10,361 \\
\hline 2008 & 5 & 2008 & 8,504 & 6,287 & 5,931 & 308 & 8,551 \\
\hline 2008 & 6 & 2008 & 7,301 & 3,466 & 2,981 & 336 & 7,450 \\
\hline 2008 & 7 & 2008 & 6,941 & 1,625 & 1,434 & 509 & 6,623 \\
\hline 2008 & 8 & 2008 & 6,543 & 2,735 & 2,614 & 665 & 5,999 \\
\hline 2008 & 9 & 2008 & 5,972 & 3,272 & 3,166 & 500 & 5,577 \\
\hline Minimum & & & 4,496 & 0 & 226 & 254 & 4,083 \\
\hline Mean & & & 11,555 & 9,592 & 11,467 & 464 & 9,217 \\
\hline Median & & & 7,555 & 4,706 & 4,770 & 347 & 6,696 \\
\hline Maximum & & & 95,268 & 149,306 & 193,194 & 1,051 & 51,044 \\
\hline
\end{tabular}

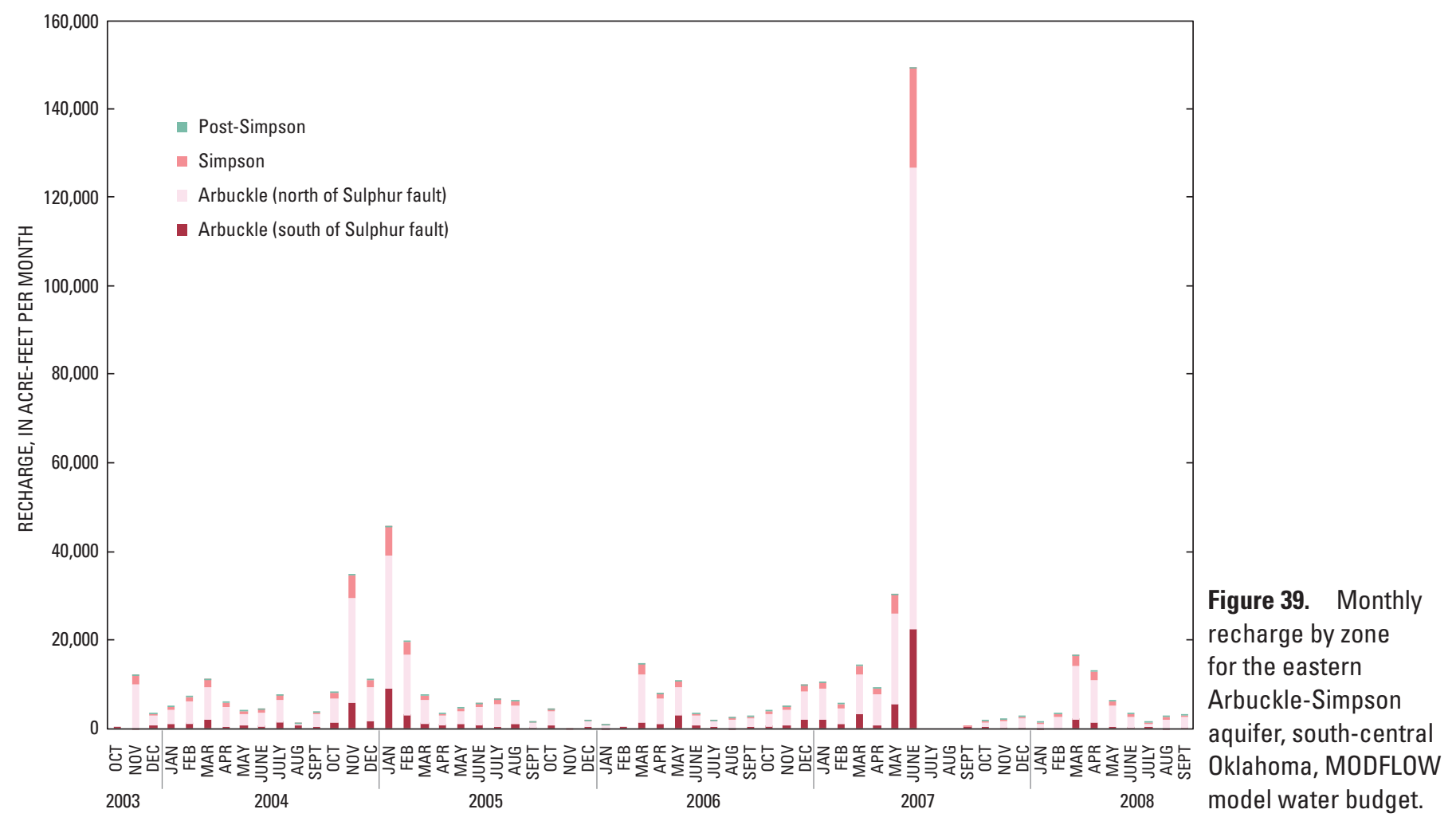




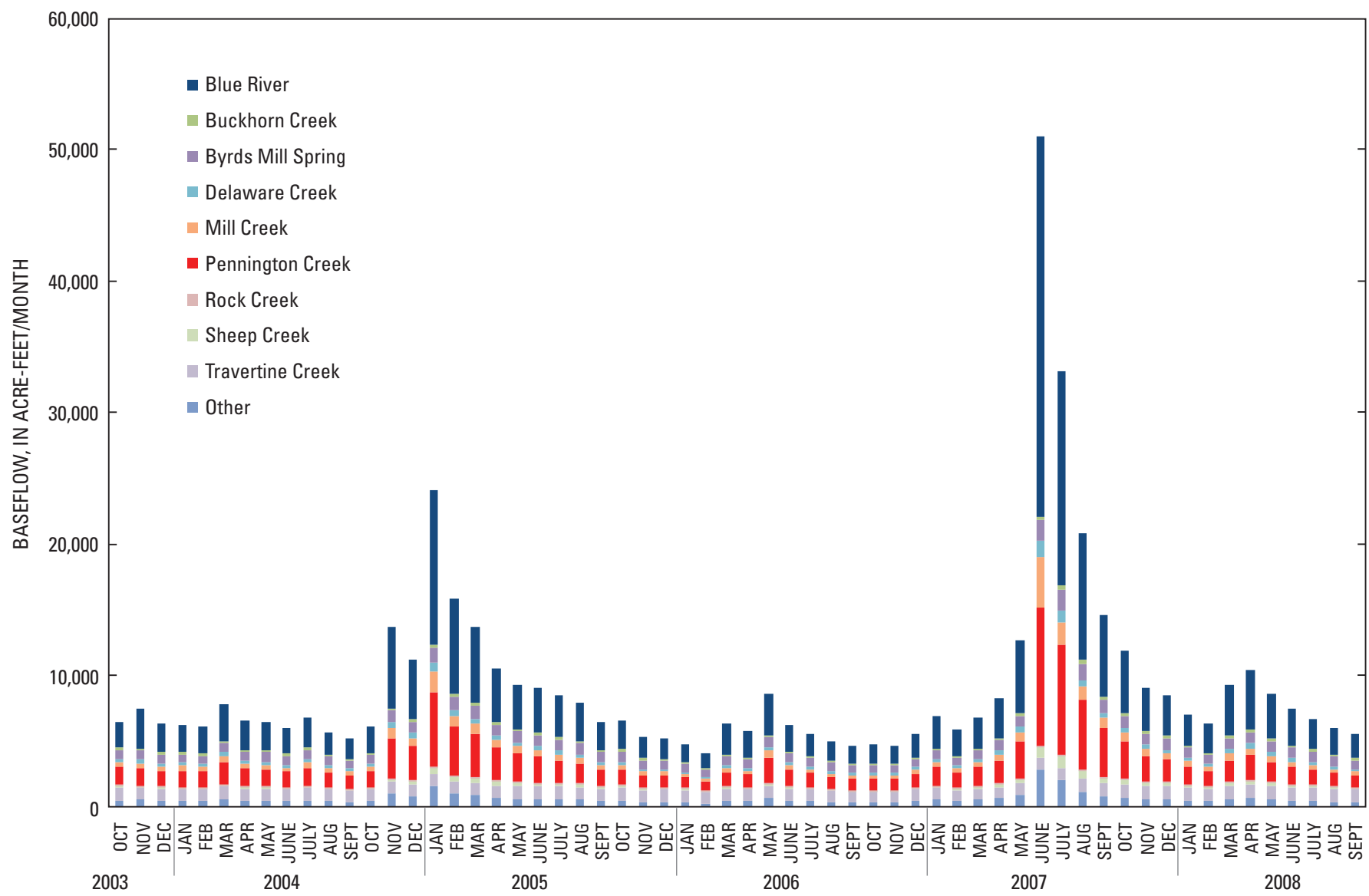

Figure 40. Monthly base flow to streams for the eastern Arbuckle-Simpson aquifer, south-central Oklahoma, MODFLOW model water budget.

\section{Simulations of Pathlines and Groundwater Traveltimes}

A particle-tracking model, MODPATH (Pollock, 1994), was used to calculate pathlines and groundwater traveltimes in the eastern Arbuckle-Simpson aquifer. MODPATH is a particle-tracking model that computes three-dimensional flow paths from output from MODFLOW simulations. MODPATH uses a semianalytical particle-tracking method to visualize the flow paths, referred to as "pathlines" of hypothetical particles of water moving through a groundwater-flow system.

Pathlines were calculated for the eastern ArbuckleSimpson aquifer by placing hypothetical particles at every 5 th model cell in layer 1 that was simulated as ArbuckleTimbered Hills or Simpson hydrostratigraphic units in the calibrated steady-state MODFLOW model. Particles were tracked forward to discharge points and are shown on figure 41. The pathlines are overlain on the subsurface watersheds (fig. 41) delineated from the potentiometric-surface maps (as described in the Subsurface Watersheds section of this report). MODFLOW/MODPATH pathlines are generally in agreement with the subsurface watersheds delineated from the potentiometric surfaces. In particular, the pathlines show that a large part of the upper Blue River surface watershed is in the Byrds Mill Spring subsurface watershed, as described in the Subsurface Watersheds section of this report. Qualitative agreement between the pathlines and independently delineated subsurface watersheds increases confidence in the model calibration and simulation results.

MODPATH can calculate time of travel along groundwater flow paths. For MODPATH to calculate time of travel of the hypothetical particles of water along pathlines, porosity must be supplied to MODPATH. As described in the Hydraulic Properties section of this report, Puckette and others (2009) determined a porosity of about 0.20 for the Simpson hydrostratigraphic unit from geophysical logs, and Rahi and Halihan (2009) determined a porosity of about 0.15 for the Arbuckle-Timbered Hills hydrostratigraphic unit. However, other studies have shown that when modeling karst aquifers as equivalent porous media, the model porosity commonly is less than the total porosity. Kuniansky and others (2001) determined in the Edwards aquifer that dividing the minimum 


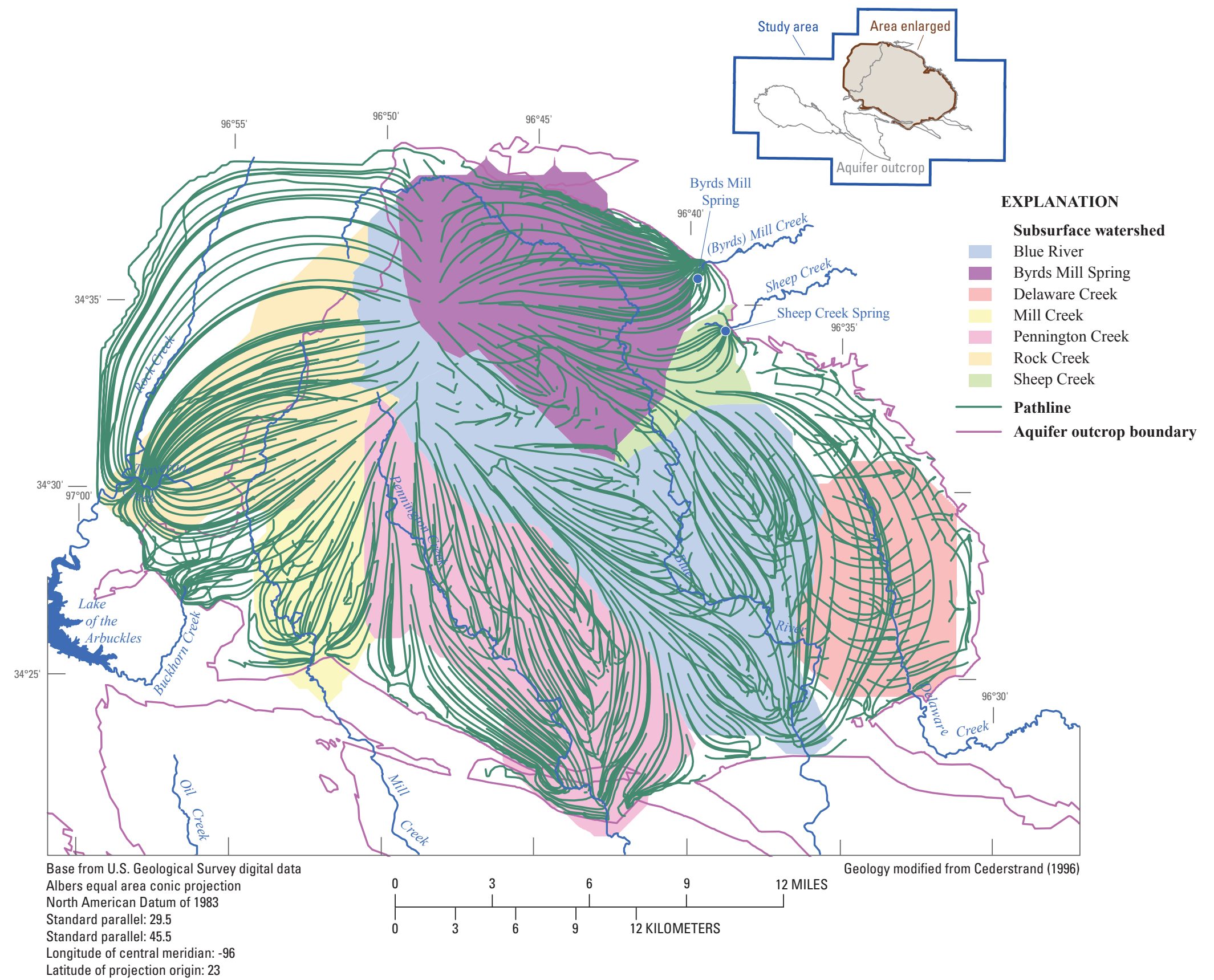

Figure 41. Pathlines computed by MODPATH based on the calibrated steady-state MODFLOW model of the eastern Arbuckle-Simpson aquifer, south-central Oklahoma. 
rock matrix porosity by 10 was necessary to achieve times of travel comparable to tritium dating in groundwater samples. Shoemaker and others (2007) state the following:

"By using field tracer test data or geochemical isotope age data in dual porosity systems, one can use the equivalent porous media approach to perform transport simulations by finding an effective porosity that will yield the average time of travel to match the tracer test or geochemical breakthrough data. Because pore velocity is inversely proportional to effective porosity, a very small (less than 5 percent) effective porosity value is often required to match field measured times of travel when, in actuality, the percentage by volume of connected pore space could be more than 40 percent."

A range of porosity was tested for the eastern ArbuckleSimpson MODFLOW model. Traveltimes were calculated by using the same pathlines calculated for the steady-state model shown in figure 41 and a porosity of 0.008 , considered to be representative of the storage coefficient described in the Hydraulic Properties section of this report and the lower limit of a possible porosity for the Arbuckle-Timbered Hills hydrostratigraphic unit. Time of travel ranged from almost 0 to more than 4 million years, but the minimum and maximum ages are not representative of the groundwaterflow system. The shortest traveltimes are associated with particles that start close to drain nodes. The longest traveltimes are associated with particles that flow along the edge of the simulated groundwater-flow system; the 99th percentile time of travel of 15,931 years is representative of the longest traveltimes based on residence time of groundwater, which is the time that groundwater was resident in the aquifer since recharge. Christenson and others (2009) using carbon-14, chlorofluorocarbons, and helium-3/tritium to determine the age of groundwater throughout the Arbuckle-Simpson aquifer, reported that groundwater ages from 34 of 36 water samples (the other two samples are discussed later) were considered to be modern, meaning the groundwater entered the aquifer after about 1950. The 75th percentile for MODPATHsimulated traveltimes was 69.2 years, meaning that 75 percent of the traveltimes were less than 69.2 years - qualitatively comparable to the recharge ages reported in Christenson and others (2009).

Christenson and others (2009) determined that Vendome Well, a flowing well adjacent to Travertine Creek in CNRA, produces groundwater with an age (for the single sample analyzed) of 10,500 years. A MODPATH simulation compared MODPATH-simulated traveltimes to groundwater ages calculated from dating tracers. Vendome Well is not explicitly modeled in the MODFLOW model; the well is adjacent to Travertine Creek and discharge from the well flows directly into Travertine Creek. Therefore, discharge to Vendome Well is considered to be part of the discharge to Travertine Creek in the MODFLOW model. Particles were placed in the MODPATH model at cells under and adjacent to Travertine
Creek and tracked backward in time to the recharge area. The average traveltime for the MODPATH particles was 9,372 years, which compares favorably to the groundwater age of 10,500 years for water discharging from Vendome Well.

Christenson and others (2009) also used carbon-14 dating to determine the age of a water sample from a flowing well on the eastern part of the eastern Arbuckle-Simpson aquifer. The flowing well, referred to in that report as site 6 (N34.456 ${ }^{\circ}$ latitude, W96.549 ${ }^{\circ}$ longitude NAD 83), is 1,400 $\mathrm{ft}$ deep and produced water with a modeled carbon-14 age of 34,000 years. Particles were placed in the MODPATH model at locations corresponding to this well and tracked backward to simulate the age of water discharging to this well, but the groundwater traveltime was 573 years, younger than the carbon-14 age. Porosity was changed to 0.2 to correspond to the porosity determined by Puckette and others (2009) for the Simpson hydrostratigraphic unit. The average MODPATH traveltime then was 14,326 years, a better agreement although still younger than the carbon-14 age.

The eastern Arbuckle-Simpson aquifer MODFLOW model was not originally intended to be calibrated by using simulated pathlines or groundwater traveltime. However, the general agreement between the simulated pathlines and the subsurface drainage basins determined from the potentiometric-surface maps, and MODFLOW-simulated time of travel and the groundwater ages determined from carbon-14, chlorofluorocarbons, and helium-3/tritium, increases confidence in the accuracy of the model calibration and simulation results.

\section{Model Simplifications, Assumptions, and Limitations}

All models are simplifications of the systems represented, and, as simplifications, are based on specific assumptions and limitations. Some of the simplifications, assumptions, and limitations of the eastern Arbuckle-Simpson aquifer MODFLOW model are described in this section.

Groundwater in the Arbuckle-Simpson aquifer flows through porous media, but also flows through solutionenlarged conduits and fractures. The sandstone units in the Timbered Hills and Simpson Groups are porous media. Several caves, large enough for humans, in the study area are solution-enlarged conduits, and paleokarst at depth in the aquifer (Lynch and Al-Shaieb, 1991) likely ensures that some fraction of the groundwater flow in the aquifer is moving in conduits. The Arbuckle-Simpson aquifer contains many fractures (Halihan and others, 2009a) that are likely pathways for groundwater movement. Many voids were found in a test well drilled for this study, and some of these voids produced large quantities of water (total production from this test well was estimated to be $1,000 \mathrm{gal} / \mathrm{min}$ ). Subsequent testing of the test well by using packers to isolate intervals revealed that not all fractures produce substantial quantities of water. 
Even though flow in the Arbuckle-Simpson aquifer does not meet the assumption of porous media flow everywhere, there are valid reasons to use an equivalent porous media model for this study. The Committee on Fracture Characterization and Fluid Flow (1996, p. 321) of the U.S. National Committee for Rock Mechanics states the following:

"The representation of a flow region using uniform flow properties is best applied to cases where the scale of the problem is large, the fractures are highly interconnected, and the interest is primarily on volumetric flow, such as in groundwater withdrawal for water supply. Rocks that have been subject to multiple and extensive deformations, and (or) those with significant matrix permeabilities, are likely to be good candidates for equivalent continuum modeling."

Those conditions are met for this study of the ArbuckleSimpson aquifer because the scale of the problem is large, the objectives of the study are primarily about volumetric flow, and several factors indicate that the fractures are highly interconnected (large well yields; the high density of high-angle faults and fractures, some of which extend to the basement; and the great depth of freshwater circulation). Numerous studies have shown that at regional scales, porous media groundwater-flow models can simulate the movement of groundwater in fractured or karst aquifers with reasonable accuracy, for example, Angelini and Dragoni (1997) and Larocque and others (1999). Czarnecki and others (2009) used MODFLOW to simulate the Ozark Plateaus aquifer system, of which the Ozark aquifer is composed of karstic CambrianOrdovician rocks that are equivalent to the Arbuckle-Simpson aquifer. The equivalent porous media/MODFLOW approach has been used to successfully simulate flow at the Yucca Mountain nuclear waste repository in fractured volcanic rocks, where the results of the simulation have substantial societal implications (for example, D’Agnese and others, 1999).

Other simplifications, assumptions, and limitations in this MODFLOW groundwater-flow model of the eastern ArbuckleSimpson aquifer include the following:

1. The Arbuckle-Timbered Hills and Simpson hydrostratigraphic units extend into the subsurface to the north, west, and east but contain saline water, indicating those parts of the aquifer are not part of the freshwater flow system and are modeled as no-flow boundaries at the inferred location of the fresh/saline water interface. Large withdrawals of freshwater from the aquifer may cause this saline water to migrate into the freshwater zone, which could not be simulated with a no-flow boundary. However, this model was not designed for that purpose;

2. Discharge to streams and springs was simulated by the MODFLOW drain function that does not permit the simulation of losing streams (Arbuckle-Simpson streams are predominantly gaining);

3. Horizontal hydraulic conductivity was sufficiently specified as uniform over three zones: the Arbuckle-Timbered Hills hydrostratigraphic unit, the Simpson hydrostratigraphic unit, and the postSimpson hydrostratigraphic unit;

4. Recharge was sufficiently specified spatially when simulated as uniform over four zones: Arbuckle-Timbered Hills hydrostratigraphic unit north of the Sulphur fault, Arbuckle-Timbered Hills hydrostratigraphic unit south of the Sulphur fault, Simpson hydrostratigraphic unit, and postSimpson hydrostratigraphic unit;

5. Recharge was sufficiently specified temporally as daily input, as computed by the RORA program, and subject to the assumptions and limitations of that program;

6. The vertical anistropy was sufficiently specified as uniform over four zones: ArbuckleTimbered Hills hydrostratigraphic unit, Simpson hydrostratigraphic unit, post-Simpson hydrostratigraphic unit, and an enhanced vertical hydraulic conductivity zone, in cells under Buckhorn, Byrds Mill Spring, Sheep, and Travertine Creeks;

7. Groundwater withdrawals were approximated as a continuous discharge such that the sum of the total daily continuous discharge equaled the estimated monthly total discharge; and

8. Model construction and calibration were optimized for simulating groundwater discharge to Blue River and Pennington Creek.

\section{Simulations of Groundwater Withdrawals Distributed as an Equal Proportionate Share}

The primary objective of the Arbuckle-Simpson Hydrology Study was to provide information to the OWRB to provide a basis for the Board to determine the amount of water that can be withdrawn from the aquifer while being protective of streams and springs, as mandated by Oklahoma Senate Bill 288. Senate Bill 288 requires the OWRB to approve a maximum annual yield that will ensure that any permit for the removal of water from the groundwater basin (as stated in the Introduction section of this report, the term "groundwater basin" is defined by the State of Oklahoma as "a distinct underground body of water overlain by contiguous land having substantially the same geological and hydrological characteristics and yield capabilities") will not reduce the 
natural flow of water from springs or streams emanating from the basin. The mandate imposed by Senate Bill 288 is open to interpretation because the Act neither defines "natural flow" nor states how the reduction of natural flow of water from springs or streams is to be determined. The approach taken for this study was to interpret "natural flow" as observed streamflow conditions for water years 2004 through 2008 and to execute simulations of groundwater withdrawals distributed uniformly across the aquifer for those water years. Results of the simulations were then compared to observed conditions. The results of these simulations do not predict the future; rather, the simulations quantify the effects of different distributions and magnitudes of hypothetical groundwater withdrawals, although those distributions and magnitudes are unlikely to be implemented exactly as simulated.

Several principles were used in devising the simulations of distributed withdrawals. The simulations used the same hydraulic parameters as used in the transient model. Stream and spring flows are maintained in the long term (during time periods of years) by water entering the aquifer as recharge (during short time spans, on the order of days to weeks, stream and spring flows are maintained by water from storage), and, therefore, groundwater withdrawals could not exceed recharge. In fact, for longer time scales (years to decades) withdrawals must be less than recharge because if withdrawals equal or exceed recharge then stream and spring flow eventually would be reduced to zero.

Another principle was based on Oklahoma's groundwater law. Groundwater in Oklahoma is a property right; the owner of the surface owns the groundwater beneath, which is subject to reasonable regulations (Walker and Bradford, 2009). The maximum annual yield (previously defined in the Introduction section of this report) is the total amount of water that can be withdrawn from a specific groundwater basin in any year; the OWRB also uses the term "equal proportionate share" to describe the allocation of water to all holders of water rights on land overlying a groundwater basin. The amount of water a permitted user can withdraw from a groundwater basin is proportional to the amount of land dedicated to a groundwater-use permit. For example, if the equal proportionate share is set at 1.0 (acre-ft/acre)/ year for a specific groundwater basin and a permit holder dedicates 100 acres of land to a permit, that permit holder is entitled to withdraw 100 acre-ft from the basin in any year. The OWRB traditionally permits the equal proportionate share of groundwater in units of (acre-ft/acre)/year, and this terminology is used in this report. Canceling units results in a rate (length/time) that is the same manner that units of recharge is expressed; for example, a recharge rate of 12 inches per year is equivalent to a recharge rate of 1.0 (acre-ft/acre)/year.

Simulations of distributed withdrawals assume that wells will be developed on all land overlying the aquifer. An advantage of assuming uniform development is that where development will take place is not relevant. The simulations of distributed withdrawals simulated as an equal proportionate share placed a hypothetical well in every model cell in MODFLOW model layer 3 in which the hydrostratigraphic unit in layer 3 was the Arbuckle-Timbered Hills or Simpson hydrostratigraphic unit. Layer 3 was selected because the layer is at a depth of $60 \mathrm{~m}(197 \mathrm{ft})$ to $140 \mathrm{~m}(459 \mathrm{ft})$ below land surface. Most wells completed in the Arbuckle-Simpson aquifer to provide more than minimal capacity are drilled deeper than $200 \mathrm{ft}$.

The simulations of distributed withdrawals did not include the reported groundwater use for the eastern ArbuckleSimpson aquifer. Simulated withdrawals only include the hypothetical wells simulating distributed withdrawals. Three simulations of distributed withdrawals were tested, allocating groundwater withdrawals at $0.125,0.250$, and 0.392 (acre-ft/ acre)/year. The rate of 0.392 (acre-ft/acre)/year is equivalent to 4.7 inches per year, which was the average recharge rate for the Arbuckle-Simpson aquifer stated in Fairchild and others (1990). Although the analysis of recharge prepared as part of this study (see the Recharge subsection in the Groundwater section of this report) shows that describing the average annual recharge rate for the Arbuckle-Simpson aquifer as 4.7 inches per year is an oversimplification of the aquifer recharge processes, this number is widely known by Arbuckle-Simpson interest groups and is of the right order of magnitude as a general description of the annual average aquifer recharge rate.

As described in the Groundwater Withdrawals section of this report, groundwater is not withdrawn from the Arbuckle-Simpson aquifer at a constant rate during the course of a year. Withdrawals are greatest in August (12.12 percent of total annual withdrawal) and least in March (6.43 percent) based on the reported water use for years 1994 through 2008. Distributed withdrawals were proportioned to the fraction of reported groundwater withdrawn monthly to more realistically simulate the withdrawal of groundwater. Therefore, each specific month had the same groundwater withdrawal as that same month in the 5-year simulation, and each year in the 5-water-year period had the same total annual groundwater withdrawals.

The 5-year total and average annual groundwater withdrawals for the calibrated transient model simulation and three simulations of distributed withdrawals are shown in table 21. The groundwater withdrawals used in the calibrated transient simulation shown in table 21 do not match the reported groundwater use shown in table 12 (in the Groundwater Withdrawals section of this report) because (1) table 21 is based on water year (October 1 through September 30 ) but table 12 is based on calendar year; (2) simulated groundwater withdrawals were calculated before reported water use was completely available for calendar year 2008, and, therefore, simulated groundwater withdrawals for water year were based on partial information; and (3) some wateruse reports from permit holders were never submitted to the OWRB; after exhausting all efforts to acquire the data (from either the landowner or the Oklahoma Department of Environmental Quality), water use for a missing report was estimated based on historical use. 
Table 21. Five-year total and average annual groundwater withdrawals for the calibrated transient model and simulations of withdrawals distributed as an equal proportionate share.

[EPS, equal proportionate share; (A-F/A)/Yr, (acre-feet/acre)/year]

\begin{tabular}{lcc}
\hline \multicolumn{1}{c}{ Simulation } & $\begin{array}{c}\text { 5-year total groundwater } \\
\text { withdrawal (acre-feet) }\end{array}$ & $\begin{array}{c}\text { Average annual groundwater } \\
\text { withdrawal (acre-feet) }\end{array}$ \\
\hline $\begin{array}{c}\text { Simulated reported water use from the } \\
\text { calibrated transient model }\end{array}$ & 27,818 & 5,564 \\
$\mathrm{EPS}=0.125(\mathrm{~A}-\mathrm{F} / \mathrm{A}) / \mathrm{Yr}$ & 141,974 & 28,395 \\
$\mathrm{EPS}=0.250(\mathrm{~A}-\mathrm{F} / \mathrm{A}) / \mathrm{Yr}$ & 283,949 & 56,790 \\
$\mathrm{EPS}=0.392(\mathrm{~A}-\mathrm{F} / \mathrm{A}) / \mathrm{Yr}$ & 445,232 & 89,046 \\
\hline
\end{tabular}

Because all the simulations of distributed groundwater withdrawals were greater than the 2004-8 reported groundwater use, the model simulated water coming from storage as the simulated potentiometric surface declined. To determine the long-term effects of simulated distributed withdrawals on streamflow, a method to eliminate the effect of water coming from storage was needed. This method was determined by repeating the 5 -water-year period, by using the same 5-year recharge distribution, and by using the head distribution at the end of one 5-water-year period as the starting condition for the next simulation, until total groundwater discharge to streams and springs for the entire 5 -year simulation period changed less than 1 percent. All flow information for the simulations of distributed groundwater withdrawals are computed for the last 5-year interval in the total simulation period. Therefore, the simulations of distributed withdrawals are intended to simulate the hydrologic conditions in the eastern Arbuckle-Simpson aquifer for the 5-water-year (2004-8) time period based on specific equal-proportionate shares.

The depletion of average streamflow and average base flow for the 5-water-year period 2004-8 for the Blue River near Connerville, Oklahoma, and the Pennington Creek near Reagan, Oklahoma, streamgages for the three simulations of distributed withdrawals, and the gaged streamflow data, is shown in table 22. Depletion of average flows is shown in figure 42 for the three simulations, expressed as an equal proportionate share and as the average annual groundwater withdrawal. Simulated depletion of average streamflow for water years 2004-8 for the Blue River near Connerville, Oklahoma, streamgage was 17.62 percent for a distributed withdrawal of 0.125 (acre-ft/acre)/year, 35.63 percent for a distributed withdrawal of 0.250 (acre-ft/acre)/year, and 53.49 percent for a distributed withdrawal of 0.392 (acre-ft/ acre)/year. Simulated depletion of average streamflow for water years 2004-8 for the Pennington Creek near Reagan, Oklahoma, streamgage was 18.18 percent for a distributed withdrawal of 0.125 (acre-ft/acre)/year, 36.22 percent for a distributed withdrawal of 0.250 (acre-ft/ acre)/year, and 56.59 percent for a distributed withdrawal of 0.392 (acre-ft/acre)/year.

The depletion of the 5-year average base flow and streamflow shown in figure $42 \mathrm{~A}$ and figure $42 \mathrm{~B}$ are the same, but the $\mathrm{x}$-axes are different. Figure 42A expresses groundwater withdrawal as an equal proportionate share, and figure 42B expresses groundwater withdrawals as an average annual groundwater withdrawal. By comparison, the estimated groundwater use was 5,564 acre-ft per year for the 5-wateryear period 2004-8.

Base-flow depletion is greater, expressed as a fraction, than streamflow depletion in the three simulations of distributed withdrawals. Streamflow includes runoff, and runoff is not modeled by the eastern Arbuckle-Simpson aquifer MODFLOW model. Runoff is calculated by using the PART program (Rutledge, 1998) independently of the model and added to base flow (groundwater discharge). The process of simulating the eastern Arbuckle-Simpson aquifer assumed that only base flow is depleted by groundwater withdrawals, and therefore, the fractional depletion is greater for base flow than streamflow.

The 5-year average streamflows include large flows during and after major storms. However, aquatic habitat and the aesthetic beauty of the springs and streams of the eastern Arbuckle-Simpson aquifer are sensitive to low flows. Exceedance statistics were calculated for total streamflows at the Blue River near Connerville, Oklahoma, and the Pennington Creek near Reagan, Oklahoma, streamgages to assess the effects of groundwater withdrawals on low flows. The exceedance statistics were calculated by ranking the daily total streamflows from the 5-water-year MODFLOW simulations and calculating percentiles. The 25 th percentile represents the streamflow that was exceeded 75 percent of the time and was considered to be a measure of low flow of the two streams. The depletions of the 75 percent exceedance (25th percentile) of streamflow for the 5-water-year period for the Blue River near Connerville, Oklahoma, and the Pennington Creek near Reagan, Oklahoma, streamgages for the three simulations of distributed withdrawals, and gaged streamflows, are shown in table 23. Depletion of average streamflows are shown in figure 43A for the simulations of distributed withdrawals expressed as an equal proportionate share and in figure 43B expressed as the average annual groundwater withdrawal. Streamflow depletions calculated on the basis of the 25th percentile of daily streamflow (table 23) are larger (more depletion) than depletions calculated on average streamflows (table 22), even though both depletions 
Table 22. Depletion of average flows for water years 2004-8 for Blue River near Connerville, Oklahoma, and Pennington Creek near Reagan, Oklahoma, simulated by the eastern Arbuckle-Simpson aquifer MODFLOW model based on groundwater withdrawals distributed as an equal proportionate share.

[EPS, equal proportionate share; (A-F/A), acre-feet/year; A-F, acre-feet; Yr, year; ft³/s, cubic feet per second; NA, not applicable]

\begin{tabular}{|c|c|c|c|c|c|c|c|c|}
\hline Simulation & $\begin{array}{l}\text { 5-year total } \\
\text { groundwater } \\
\text { withdrawal } \\
\text { (A-F) }\end{array}$ & $\begin{array}{c}\text { 5-year } \\
\text { average annual } \\
\text { groundwater } \\
\text { withdrawal } \\
\text { (A-F/Yr) }\end{array}$ & $\begin{array}{c}\text { 5-year } \\
\text { average gaged } \\
\text { streamflow } \\
\left(\mathrm{ft}^{3} / \mathbf{s}\right)\end{array}$ & $\begin{array}{c}\text { 5-year average } \\
\text { MODFLOW- } \\
\text { simulated } \\
\text { streamflow } \\
\left(\mathrm{ft}^{3} / \mathrm{s}\right)\end{array}$ & $\begin{array}{c}\text { 5-year average } \\
\text { PART base flow } \\
\left(\mathrm{ft}^{3} / \mathrm{s}\right)\end{array}$ & $\begin{array}{l}\text { 5-year average } \\
\text { MODFLOW- } \\
\text { simulated base } \\
\text { flow }\left(\mathrm{ft}^{3} / \mathrm{s}\right)\end{array}$ & $\begin{array}{c}\text { Streamflow } \\
\text { depletion } \\
\text { (percent) }\end{array}$ & $\begin{array}{c}\text { Base-flow } \\
\text { depletion } \\
\text { (percent) }\end{array}$ \\
\hline & & & \multicolumn{6}{|c|}{ Blue River near Connerville (07332390) } \\
\hline Reported water use & 27,818 & 5,564 & 92.92 & 92.98 & 61.28 & 61.34 & 0.00 & 0.00 \\
\hline $\mathrm{EPS}=0.125(\mathrm{~A}-\mathrm{F} / \mathrm{A}) / \mathrm{Yr}$ & 141,974 & 28,395 & NA & 76.60 & NA & 44.96 & 17.62 & 26.71 \\
\hline $\mathrm{EPS}=0.250(\mathrm{~A}-\mathrm{F} / \mathrm{A}) / \mathrm{Yr}$ & 283,949 & 56,790 & NA & 59.85 & NA & 28.21 & 35.63 & 54.01 \\
\hline \multirow[t]{2}{*}{$\mathrm{EPS}=0.392(\mathrm{~A}-\mathrm{F} / \mathrm{A}) / \mathrm{Yr}$} & 445,232 & 89,046 & NA & 43.24 & NA & 11.60 & 53.49 & 81.08 \\
\hline & & & \multicolumn{6}{|c|}{ Pennington Creek near Reagan (07331300) } \\
\hline Reported water use & 27,818 & 5,564 & 42.97 & 42.69 & 32.47 & 32.19 & 0.00 & 0.00 \\
\hline $\mathrm{EPS}=0.125(\mathrm{~A}-\mathrm{F} / \mathrm{A}) / \mathrm{Yr}$ & 141,974 & 28,395 & NA & 34.93 & NA & 24.42 & 18.18 & 24.14 \\
\hline $\mathrm{EPS}=0.250(\mathrm{~A}-\mathrm{F} / \mathrm{A}) / \mathrm{Yr}$ & 283,949 & 56,790 & NA & 27.23 & NA & 16.72 & 36.22 & 48.04 \\
\hline $\mathrm{EPS}=0.392(\mathrm{~A}-\mathrm{F} / \mathrm{A}) / \mathrm{Yr}$ & 445,232 & 89,046 & NA & 18.53 & NA & 8.03 & 56.59 & 75.06 \\
\hline
\end{tabular}




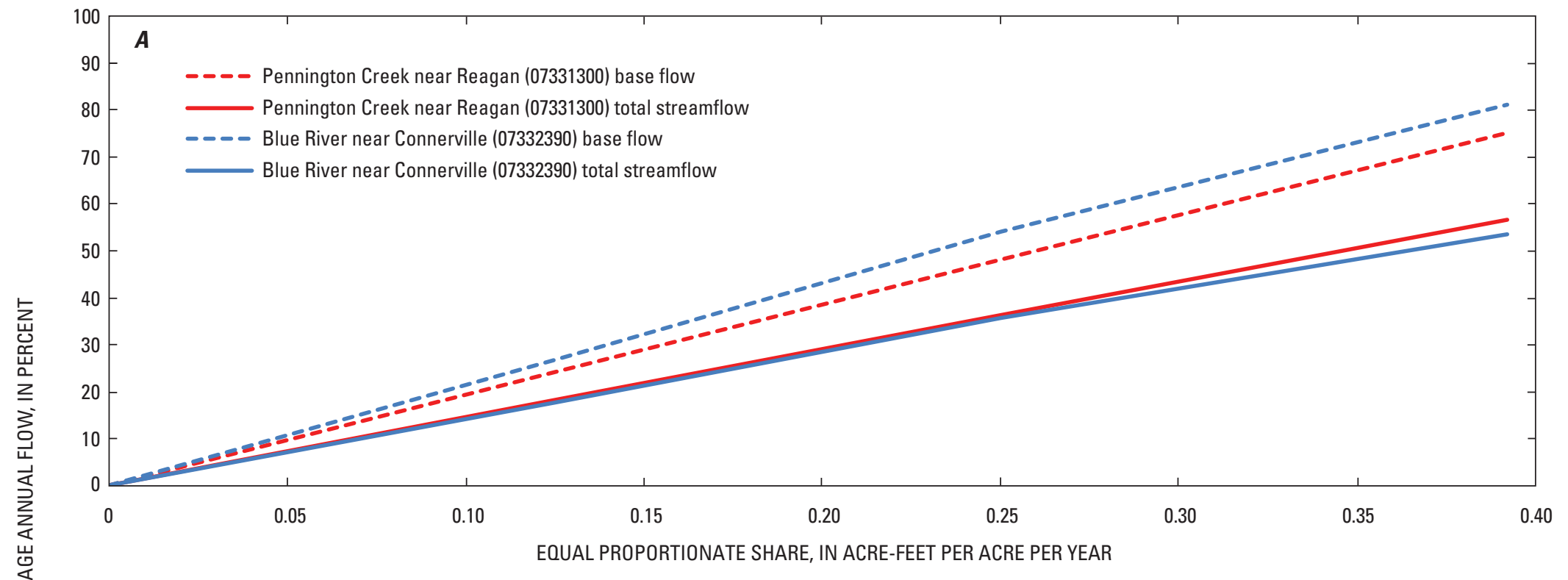

Figure 42. Depletion of 5-year (water years 2004-8) average flow of Blue River near Connerville, Oklahoma, and Pennington Creek near Reagan, Okla., based on MODFLOWsimulated groundwater withdrawals distributed as an equal proportionate share. 


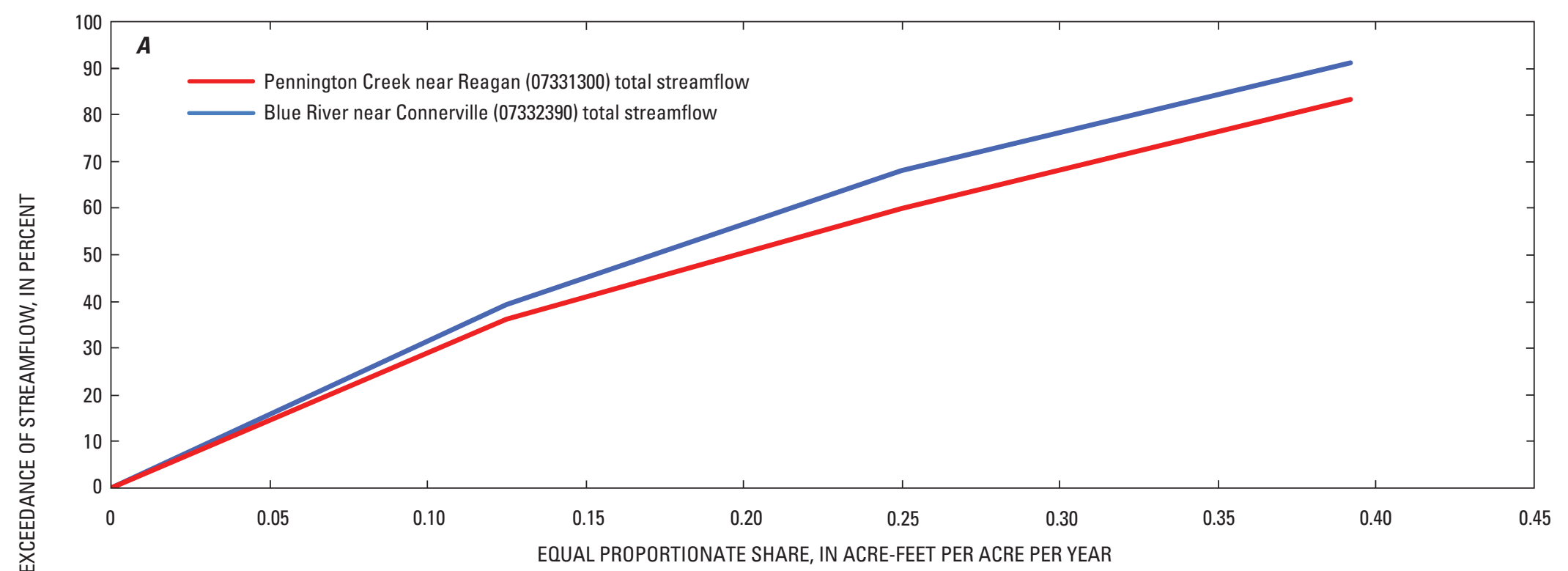

EQUAL PROPORTIONATE SHARE, IN ACRE-FEET PER ACRE PER YEAR

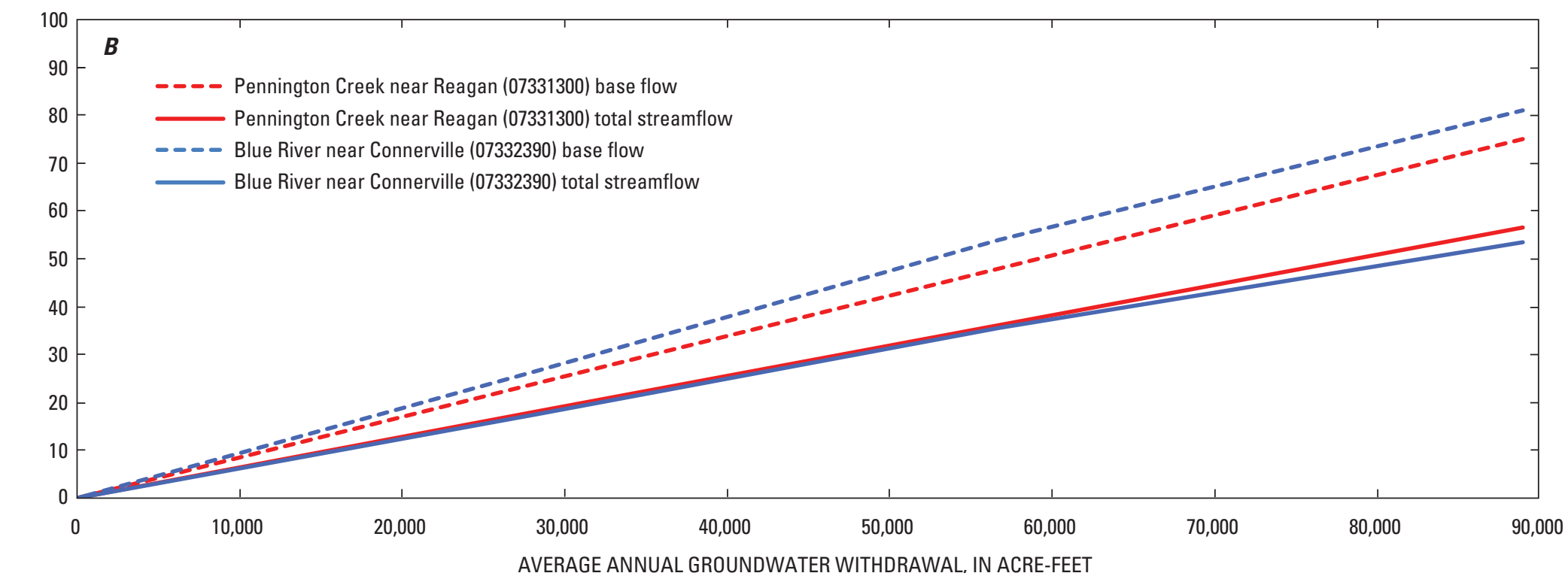

Figure 43. Depletion of the 75-percent exceedance of streamflow of Blue River near Connerville, Oklahoma, and Pennington Creek near Reagan, 0kla., for water years 2004-8 based on MODFLOW-simulated withdrawals distributed as an equal proportionate share. 
are calculated from the same MODFLOW model simulations. This difference is because the average streamflows include high flows but streamflows based on the 25 th percentile (75-percent exceedance) do not.

\section{Test-of-Concept Simulations}

Because of concerns that large-scale withdrawals of water from the Arbuckle-Simpson aquifer would cause decreased streamflow in rivers and springs, the model was optimized to simulate the effects on Blue River and Pennington Creek, the streams with the largest streamflows. The model can be used to test other aspects of the groundwater-flow system, but as the tests deviate from the conditions for which the model was optimized and calibrated, the limitations on the applicability of the results become greater. Additional simulations were performed as part of this study beyond the optimized and calibrated conditions, and these simulations are described here as "test-of-concept simulations." Many of the test-ofconcept simulations were performed on the same calibrated model used to test groundwater withdrawals distributed as an equal proportionate share, but the simulations tested aspects of the groundwater-flow system for which the model was not optimized. The limitations of these test-of-concept simulations are described with each simulation.

\section{Effects of Distributed Withdrawals on Streams Other Than Blue River and Pennington Creek}

The same MODFLOW model used to simulate the effects of distributed withdrawals on streamflow and base flow in Blue River and Pennington Creek was used to calculate the effect of distributed withdrawals on all other streams simulated by the eastern Arbuckle-Simpson groundwaterflow model. The limitations and assumptions built into the MODFLOW model did not change for these simulations, but streamflow and base flow for streams other than Blue River and Pennington Creek were not considered during the transient calibration process (although streamflows to these individual streams were flow observations in the steady-state calibration process). Therefore, the utility of the simulations of effects of distributed withdrawals on streams other than Blue River and Pennington Creek is to demonstrate that these other streams would be affected by distributed withdrawals, although the magnitudes of the streamflows and the depletion should not be considered to be calibrated.

Buckhorn Creek, Delaware Creek, Sheep Creek, and all other streams were not gaged, therefore, the 5-year average base flow is not known and cannot be compared to any measured streamflows. Three streams, Byrds Mill Spring, Mill, and Rock Creeks, were gaged, but each of these streams has issues that make comparison to simulated flows less than ideal:
1. Byrds Mill Spring: Flow to Byrds Mill Spring is dominated by groundwater discharge, and MODFLOW is not optimal to simulate discharge to a single spring. Flow from Byrds Mill Spring is measured by a combination of flow meters and a weir, and measurements may have additional limitations greater than a standard streamgage.

2. Mill Creek: A streamgage was installed on Mill Creek at the point where the stream flows off the aquifer (USGS streamgage 07331200, Mill Creek near Mill Creek, Oklahoma) and became operational on September 7, 2006, after the start of the Arbuckle-Simpson Hydrology Study and, therefore, fewer data are available to compare to than on Blue River and Pennington Creek. Additionally, substantial amounts of surface water are withdrawn directly from Mill Creek, making calculation of recharge by using hydrograph displacement methods or calculation of the base-flow component of streamflow by using hydrograph separation methods difficult.

3. Rock Creek: The Rock Creek near Sulphur, Oklahoma, streamgage (07329852) includes streamflow from Travertine Creek, which is thought to be primarily discharge from the Arbuckle-Simpson aquifer. However, most of the Rock Creek watershed is on the postSimpson hydrostratigraphic unit, for which field measurements of the hydraulic properties were not collected as part of the current (2011) study and were not determined during research for the study (the hydraulic properties of the post-Simpson hydrostratigraphic unit used in this study were derived from the model calibration process).

Because of these issues these three gaged streams were not used as part of the calibration process, and direct comparison between observed and simulated streamflows of those streams is not part of the analysis in this report.

The depletion of 5-year average base flow for water years 2004-8 is shown for all streams simulated by the eastern Arbuckle-Simpson aquifer MODFLOW model in table 24. Table 24 only shows base flow (groundwater discharge) because some of the streams are not gaged and a streamgage is necessary to determine the runoff component of streamflow; the MODFLOW model only simulates base flow. All streams show decreasing 5-year average base flow as distributed withdrawals increase. 
Table 23. Depletion of 75-percent exceedance of streamflow for water years 2004-08 for Blue River near Connerville, Oklahoma, and Pennington Creek near Reagan, 0kla., simulated by the eastern Arbuckle-Simpson aquifer MODFLOW model with groundwater withdrawals distributed as an equal proportionate share.

[EPS, equal proportionate share; A-F, acre-feet; Yr, Year; (A-F/A)Yr, acre-feet/acre)/year; fts/s, cubic feet per second]

\begin{tabular}{|c|c|c|c|c|c|c|c|c|}
\hline Simulation & $\begin{array}{c}\text { 5-year } \\
\text { total } \\
\text { groundwater } \\
\text { withdrawal } \\
\text { (A-F) }\end{array}$ & $\begin{array}{c}\text { Average } \\
\text { annual } \\
\text { groundwater } \\
\text { withdrawal } \\
\text { (A-F/Yr) }\end{array}$ & $\begin{array}{c}\text { Blue } \\
\text { River } \\
\text { gaged } \\
\text { streamflow } \\
\text { daily value } \\
\text { 75-percent } \\
\text { exceedance } \\
\left(\mathrm{ft}^{3} / \mathrm{s}\right)\end{array}$ & $\begin{array}{c}\text { Blue } \\
\text { River } \\
\text { MODFLOW- } \\
\text { simulated } \\
\text { streamflow } \\
\text { 75-percent } \\
\text { exceedance } \\
\left(\mathrm{ft}^{3} / \mathrm{s}\right) \\
\end{array}$ & $\begin{array}{c}\text { Blue } \\
\text { River stream- } \\
\text { flow depletion } \\
\text { (percent) }\end{array}$ & $\begin{array}{c}\text { Pennington Creek } \\
\text { gaged } \\
\text { streamflow } \\
\text { daily value } \\
\text { 75-percent } \\
\text { exceedance } \\
\left(\mathrm{ft}^{3} / \mathrm{s}\right)\end{array}$ & $\begin{array}{l}\text { Pennington Creek } \\
\text { MODFLOW-sim- } \\
\text { ulated } \\
\text { streamflow } \\
\text { 75-percent } \\
\text { exceedance } \\
\left(\mathrm{ft}^{3} / \mathrm{s}\right) \\
\end{array}$ & $\begin{array}{c}\text { Pennington } \\
\text { Creek } \\
\text { streamflow } \\
\text { depletion } \\
\text { (percent) }\end{array}$ \\
\hline Reported water use & 27,818 & 5,564 & 40 & 29.32 & 0.00 & 18 & 17.88 & 0.00 \\
\hline $\mathrm{EPS}=0.125(\mathrm{~A}-\mathrm{F} / \mathrm{A}) / \mathrm{Yr}$ & 141,974 & 28,395 & 40 & 18.00 & 38.61 & 18 & 11.61 & 35.07 \\
\hline $\mathrm{EPS}=0.250(\mathrm{~A}-\mathrm{F} / \mathrm{A}) / \mathrm{Yr}$ & 283,949 & 56,790 & 40 & 9.55 & 67.43 & 18 & 7.31 & 59.12 \\
\hline $\mathrm{EPS}=0.392(\mathrm{~A}-\mathrm{F} / \mathrm{A}) / \mathrm{Yr}$ & 445,232 & 89,046 & 40 & 2.67 & 90.89 & 18 & 3.09 & 82.72 \\
\hline
\end{tabular}

Table 24. Five-year average base flow for water years 2004-08 and depletion of 5-year average base flow for all streams simulated by the eastern Arbuckle-Simpson aquifer MODFLOW model based on simulations of groundwater withdrawals distributed as an equal proportionate share.

[fts $/ \mathrm{s}$, cubic feet per second; EPS, equal proportionate share; (A-F/A)/Yr, acre-feet per acre per year]

\begin{tabular}{|c|c|c|c|c|c|c|c|c|c|c|}
\hline \multirow[b]{2}{*}{ Simulation } & \multicolumn{10}{|c|}{ Stream } \\
\hline & $\begin{array}{l}\text { Blue } \\
\text { River }\end{array}$ & $\begin{array}{c}\text { Buckhorn } \\
\text { Creek }\end{array}$ & $\begin{array}{c}\text { Byrds Mill- } \\
\text { Spring }\end{array}$ & $\begin{array}{c}\text { Delaware } \\
\text { Creek }\end{array}$ & $\begin{array}{c}\text { Mill } \\
\text { Creek }\end{array}$ & $\begin{array}{l}\text { Pennington } \\
\text { Creek }\end{array}$ & $\begin{array}{l}\text { Sheep } \\
\text { Creek }\end{array}$ & $\begin{array}{c}\text { Travertine } \\
\text { Creek }\end{array}$ & $\begin{array}{l}\text { All other } \\
\text { streams } \\
\text { combined }\end{array}$ & Total \\
\hline \multicolumn{11}{|c|}{5 -year average base flow $\left(\mathrm{ft}^{3} / \mathrm{s}\right)$} \\
\hline Reported water use & 61.34 & 2.65 & 12.95 & 4.92 & 8.53 & 32.19 & 4.44 & 15.41 & 10.18 & 152.60 \\
\hline $\mathrm{EPS}=0.125(\mathrm{~A}-\mathrm{F} / \mathrm{A}) / \mathrm{Yr}$ & 44.96 & 1.79 & 11.97 & 4.47 & 6.12 & 24.42 & 3.76 & 13.59 & 8.57 & 119.64 \\
\hline $\mathrm{EPS}=0.250(\mathrm{~A}-\mathrm{F} / \mathrm{A}) / \mathrm{Yr}$ & 28.21 & 0.61 & 9.46 & 3.98 & 3.39 & 16.72 & 2.08 & 9.28 & 6.74 & 80.49 \\
\hline $\mathrm{EPS}=0.392(\mathrm{~A}-\mathrm{F} / \mathrm{A}) / \mathrm{Yr}$ & 11.60 & 0.00 & 4.54 & 3.34 & 1.04 & 8.03 & 0.42 & 2.61 & 4.54 & 36.12 \\
\hline \multicolumn{11}{|c|}{ Depletion of 5-year average base flow (percent) } \\
\hline $\mathrm{EPS}=0.125(\mathrm{~A}-\mathrm{F} / \mathrm{A}) / \mathrm{Yr}$ & 26.7 & 32.6 & 7.6 & 9.1 & 28.3 & 24.1 & 15.3 & 11.8 & 15.8 & 21.6 \\
\hline $\mathrm{EPS}=0.250(\mathrm{~A}-\mathrm{F} / \mathrm{A}) / \mathrm{Yr}$ & 54.0 & 76.8 & 26.9 & 18.9 & 60.2 & 48.0 & 53.1 & 39.8 & 33.8 & 47.3 \\
\hline $\mathrm{EPS}=0.392(\mathrm{~A}-\mathrm{F} / \mathrm{A}) / \mathrm{Yr}$ & 81.1 & 100.0 & 64.9 & 32.1 & 87.9 & 75.1 & 90.6 & 83.1 & 55.4 & 76.3 \\
\hline
\end{tabular}




\section{Effects of Distributed Withdrawals on Daily Streamflow}

Daily stress periods were used for the MODFLOW simulations of the eastern Arbuckle-Simpson aquifer although model results are not intended to be used on a daily basis. Daily streamflow data were aggregated into monthly and yearly streamflows to meet the study objectives. However, showing daily streamflow hydrographs for the Blue River near Connerville, Oklahoma, and the Pennington Creek near Reagan, Oklahoma, streamgages is instructive and appropriate as a test-of-concept. Hydrographs of daily simulated streamflow, based on distributed withdrawals as an equal proportionate share, are shown in figure 44 for the Blue River near Connerville, Oklahoma (07332390), streamgage and in figure 45 for the Pennington Creek near Reagan,
Oklahoma (07331300), streamgage. Figure 44 and figure 45 are plotted on logarithmic vertical axes and are illustrative of several concepts. A question posed by stakeholders regarding increases in groundwater withdrawals from the ArbuckleSimpson aquifer is that if streamflows return to normal levels with precipitation after a drought, would streamflows return to normal with precipitation after increases in groundwater withdrawals? Figure 44 and figure 45 show that although streamflow does increase after precipitation (indicated by sharp peaks on the hydrograph), even with an increase in groundwater withdrawals, streamflow is less with increases in withdrawals than in the absence of withdrawals. The simulations shown on each figure are identical except that a different distributed withdrawal rate, expressed as an equal proportionate share, is used for each simulation. A larger equal proportionate share results in less streamflow at every point along the hydrograph.

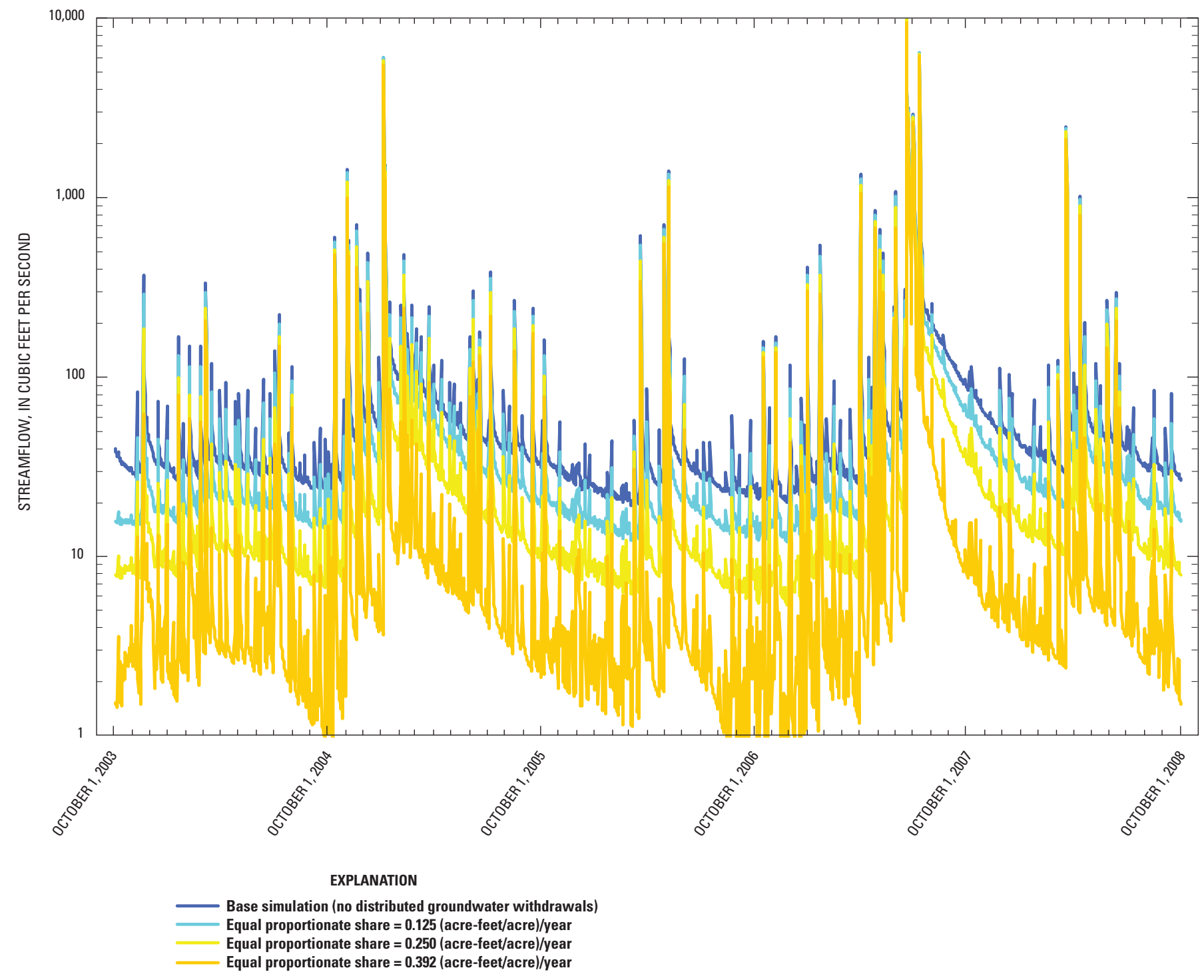

Figure 44. Simulated streamflow for Blue River near Connerville, Oklahoma (07332390), for water years 2004-8 based on groundwater withdrawals distributed as an equal proportionate share. 


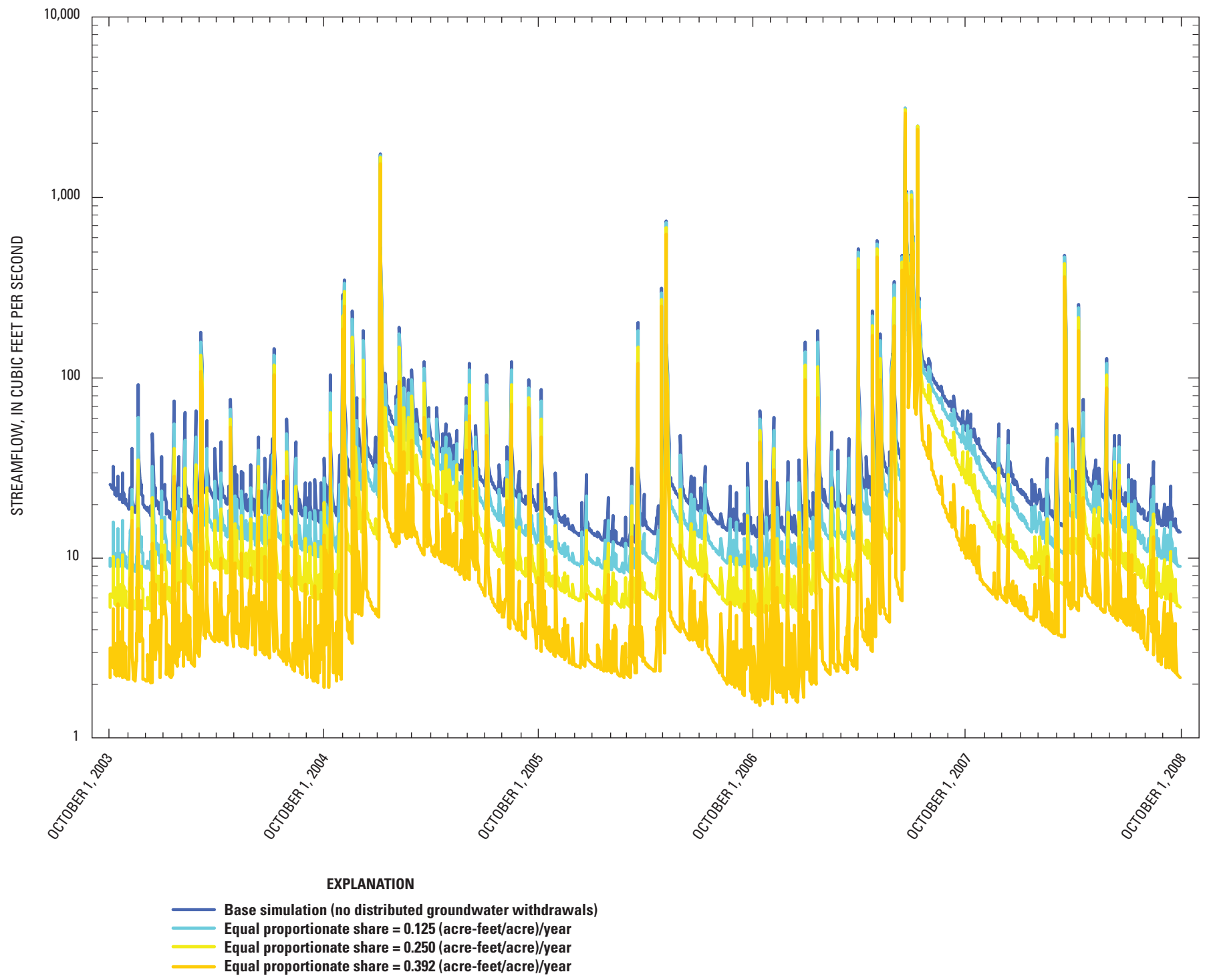

Figure 45. Simulated streamflow for Pennington Creek near Reagan, Oklahoma (07331300), for water years 2004-8 based on groundwater withdrawals distributed as an equal proportionate share.

Another concept illustrated in figure 44 and figure 45 is that although streamflows are greater at the Blue River near Connerville, Oklahoma, streamgage than at the Pennington Creek near Reagan, Oklahoma, streamgage in the base simulation, minimum streamflows are less in Blue River than in Pennington Creek at a larger equal proportionate share. This difference is thought to be caused by the elevation of Pennington Creek (about $850 \mathrm{ft}$ ) being lower than that of Blue River (about $900 \mathrm{ft}$ ) at the point where the streams flow off of the aquifer. As water levels decline in the aquifer in response to distributed groundwater withdrawals, Pennington Creek could maintain more base flow where the creek flows off of the aquifer because the streambed is at a lower elevation than the streambed of Blue River where the river flows off of the aquifer.

\section{Effects of Distributed Withdrawals on Locations of Groundwater Discharge}

Groundwater withdrawals not only cause less groundwater discharge to streams and springs, but decrease the lengths of stream channels receiving groundwater discharge. Groundwater discharges to streams and springs where the water table is in contact with the stream channel or spring orifice. As the water table declines in response to increased groundwater withdrawals, less stream channel and fewer springs will be in contact with the water table.

The same MODFLOW model used to predict the effects of distributed withdrawals on streamflow in Blue River and Pennington Creek was used to simulate the effects of 
distributed withdrawals on the locations where groundwater is discharging on the eastern Arbuckle-Simpson aquifer. The limitations and assumptions built into the MODFLOW model did not change for this simulation but the model was not calibrated to the locations of groundwater discharges to streams and springs.

The MODFLOW model computed that 779 model drain cells (fig. 46A) were discharging more than 1 cubic meter per day $\left(\mathrm{m}^{3} /\right.$ day) $\left(35 \mathrm{ft}^{3} /\right.$ day or $\left.0.18 \mathrm{gal} / \mathrm{min}\right)$ (the number is arbitrary) in the calibrated transient model on August 10, 2005. This date was selected because daily gaged streamflow at the Blue River near Connerville, Oklahoma, streamgage was $40 \mathrm{ft}^{3} / \mathrm{s}$ on that day, and $40 \mathrm{ft}^{3} / \mathrm{s}$ is the 25 -percentile (75 percent exceedance) for streamflow at that streamgage (table 7). Figure $46 \mathrm{~A}$ does not show where the model calculates that streamflow would be in stream channels because streamflow is not computed by the eastern Arbuckle-Simpson MODFLOW model; rather, the figure shows the model cells where the model calculates that more than $1.0 \mathrm{~m}^{3} / \mathrm{d}$ of groundwater would be discharging from the aquifer to the stream channel.

For comparison, figure 46B shows that 631 model drain cells would discharge more than $1 \mathrm{~m}^{3} / \mathrm{d}$ on August 10, 2005, if groundwater withdrawals distributed as an equal proportionate share of 0.125 (acre-ft/acre)/year were applied. Figure 46C shows that 455 model drain cells would discharge more than $1 \mathrm{~m}^{3} / \mathrm{d}$ on August 10, 2005, if groundwater withdrawals distributed as an equal proportionate share of 0.250 (acre-ft/ acre)/year were applied, and figure 46D shows that 274 cells would discharge more than $1 \mathrm{~m}^{3} / \mathrm{d}$ on August 10, 2005, with an equal proportionate share of 0.392 (acre-ft/acre)/year. Because of the limitations and approximations in the model, the absolute number of discharging drain cells is less important than the fact that increasing withdrawal of groundwater from the aquifer will result in fewer locations where groundwater is discharging to streams and springs.

\section{Simulation of Concentrated Groundwater Withdrawals from the Eastern Arbuckle-Simpson Aquifer}

The MODFLOW simulations of the eastern ArbuckleSimpson aquifer tested the effects of distributed withdrawals on Blue River and Pennington Creek streamflows and base flows. Simulating distributed withdrawal rates as an equal proportionate share results in small withdrawals from each cell when wells are placed in every model cell. For example, simulating an equal proportionate share of 0.125 (acre- $\mathrm{ft} /$ acre)/year uses a withdrawal rate of only $0.580 \mathrm{gal} / \mathrm{min}$ in March and $1.09 \mathrm{gal} / \mathrm{min}$ in August in each $200-\mathrm{m}$ by $200-\mathrm{m}$ model cell. Development of withdrawals from wells in this manner is unlikely, so a test to demonstrate the difference between simulating withdrawals in a distributed manner (an equal proportionate share) and concentrated withdrawals of groundwater was devised.

Simulating concentrated groundwater withdrawals requires decisions as to the location of the simulated withdrawals and the simulated volumetric flow rates. The location selected (fig. 47) was near the center of the eastern Arbuckle-Simpson aquifer and far from the springs that discharge on the perimeter of the aquifer. Withdrawal rates were set at the same rates as the simulations of withdrawals distributed as an equal proportionate share, except that the total flow from the distributed wells was concentrated at a single model cell as a hypothetical well. Because all layers in the model were specified as confined, transmissivity remains constant during a simulation although in reality, the saturated thickness, and associated transmissivity of the aquifer, would likely decrease as pumping at the large rate continued. This simplification of constant transmissivity was considered to be acceptable for testing the effect of concentrated withdrawals as a test of concept.

The effects of concentrated withdrawals on 5-year average base flow of all streams in the model are shown in table 25. Concentrated withdrawals from the selected model cell cause less depletion on 5-year average base flow at the Blue River near Connerville, Oklahoma, and the Pennington Creek near Reagan, Oklahoma, streamgages than distributed withdrawals, but other streams, such as Byrds Mill Spring and Travertine Creek, were simulated to have lesser average 5 -year base flows with concentrated, rather than distributed, withdrawals. Note that total base-flow discharge from the eastern Arbuckle-Simpson aquifer is slightly different between distributed and concentrated simulated withdrawals because the amount of water derived from storage is different between the two simulations even though the total withdrawals are the same. The purpose of comparing distributed and concentrated withdrawals is to show that concentrated pumping of groundwater may lessen the effects of withdrawals on some streams but will increase the effects on other streams. The location of the concentrated withdrawals will determine the streams most affected. A simulation with a different location of concentrated withdrawal would affect different streams; the flows in the streams closest to the concentrated withdrawals would be the most likely to be affected. 

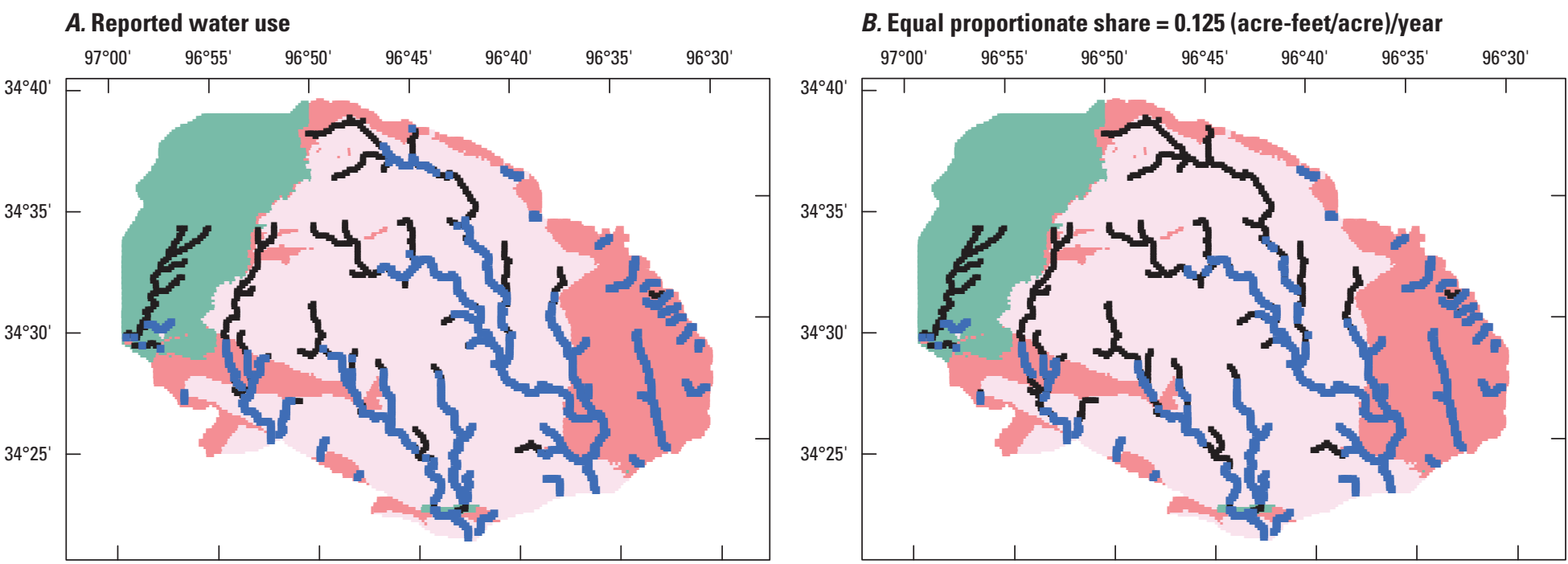

EXPLANATION

Model hydrostratigraphic unit in layer 1

Post-Simpson

Simpson

Arbuckle-Timbered Hills

MODFLOW model drain cell

- Model drain cel

discharging greater than 1.0 cubic meter per day
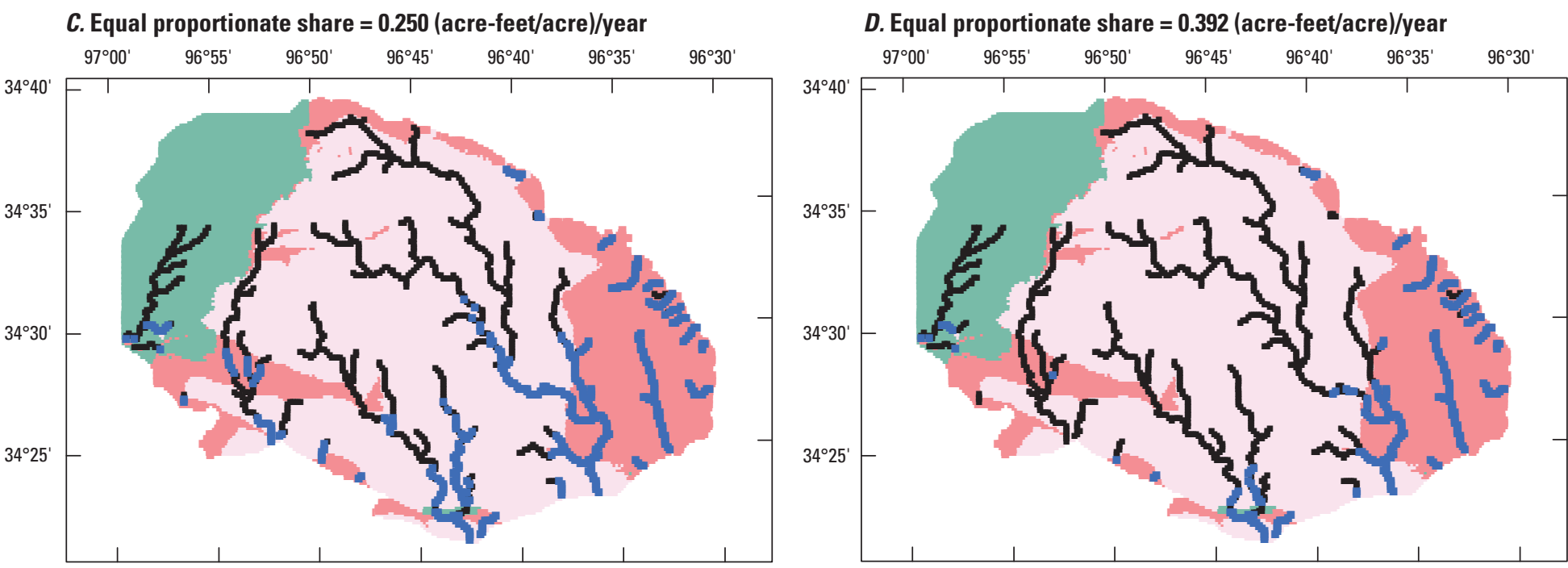

Universal Transverse Mercator projection, zone 14 north

Geology modified from Cederstrand (1996)

Figure 46. Drain cells in the eastern Arbuckle-Simpson aquifer, south-central Oklahoma, MODFLOW model discharging more than 1.0 cubic meter (35.3 cubic feet) per day on August 10, 2005, for simulations of different equal proportionate shares. 


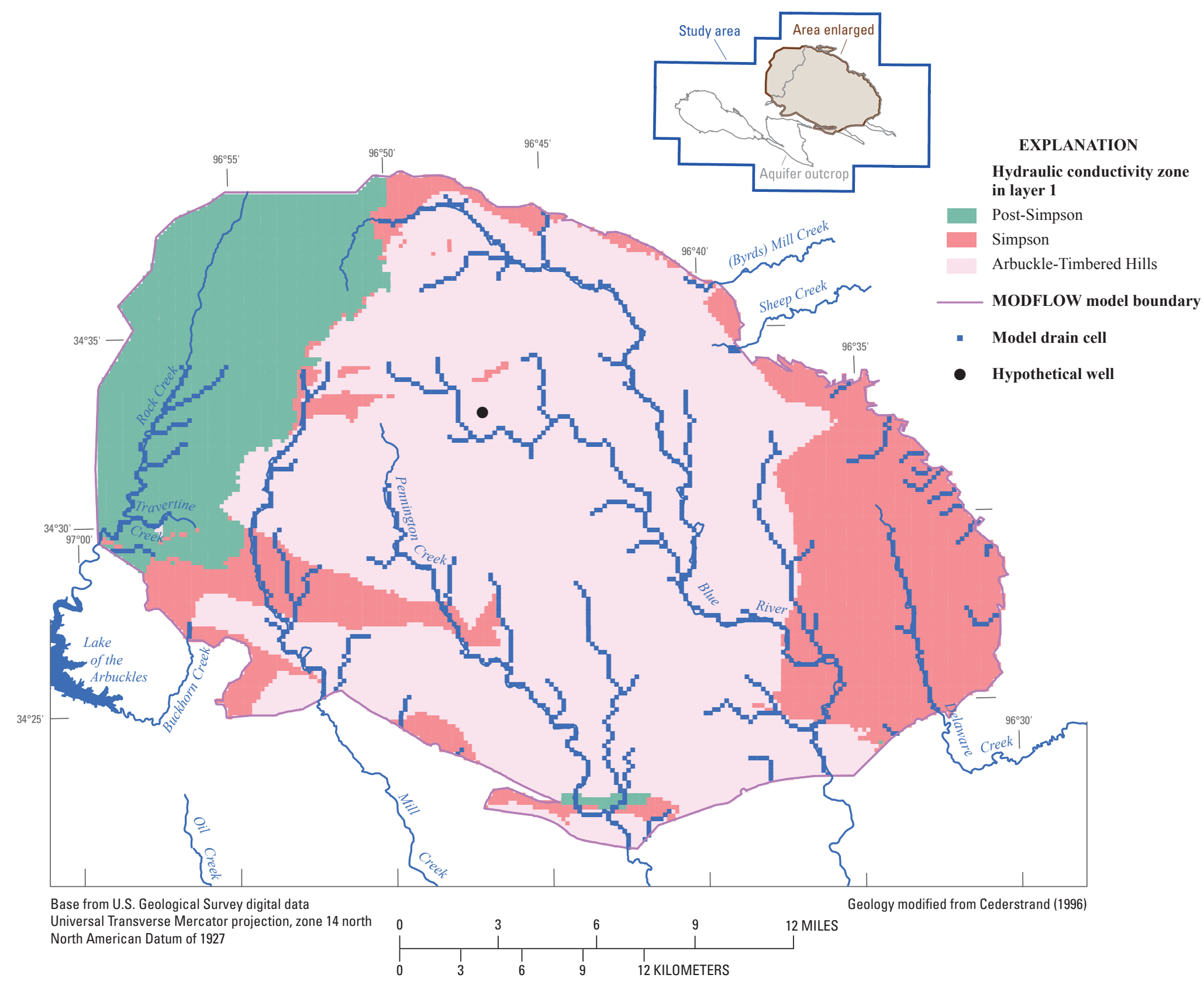

Figure 47. Location of the single MODFLOW well used to test the effects of concentrated withdrawals on the eastern Arbuckle-Simpson aquifer, south-central Oklahoma. 
Table 25. Five-year average base flow for water years 2004-8 and depletion of 5-year average base flow for all streams simulated by the eastern Arbuckle-Simpson aquifer MODFLOW based on simulations of concentrated withdrawals of groundwater.

$\left[\mathrm{ft}^{3} / \mathrm{s}\right.$, cubic feet per second; EPS, equal proportionate share; (A-F/A)/Yr, acre-feet per acre per year]

\section{Stream}

\section{Simulation:}

Concentrated pumping

expressed as an equivalent

equal proportionate share

Blue
River

$\begin{array}{ccc}\begin{array}{c}\text { Buckhorn } \\ \text { Creek }\end{array} & \begin{array}{c}\text { Byrds Mill } \\ \text { Spring }\end{array} & \begin{array}{c}\text { Delaware } \\ \text { Creek }\end{array}\end{array}$

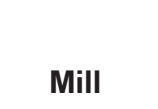

(2)

\begin{tabular}{|c|c|c|c|c|c|c|c|c|c|c|}
\hline \multicolumn{11}{|c|}{ 5-year average base flow $\left(\mathrm{ft}^{3} / \mathrm{s}\right)$} \\
\hline Reported water use & 61.34 & 2.65 & 12.95 & 4.92 & 8.53 & 32.19 & 4.44 & 15.41 & 10.18 & 152.60 \\
\hline $\mathrm{EPS}=0.125(\mathrm{~A}-\mathrm{F} / \mathrm{A}) / \mathrm{Yr}$ & 44.60 & 1.69 & 10.60 & 4.93 & 6.20 & 26.00 & 3.71 & 12.30 & 9.68 & 119.71 \\
\hline $\mathrm{EPS}=0.250(\mathrm{~A}-\mathrm{F} / \mathrm{A}) / \mathrm{Yr}$ & 32.88 & 0.19 & 5.18 & 4.89 & 2.86 & 19.36 & 1.39 & 5.47 & 8.59 & 80.81 \\
\hline $\mathrm{EPS}=0.392(\mathrm{~A}-\mathrm{F} / \mathrm{A}) / \mathrm{Yr}$ & 17.54 & 0.00 & 0.08 & 4.76 & 0.62 & 10.58 & 0.02 & 0.00 & 7.04 & 40.63 \\
\hline \multicolumn{11}{|c|}{ Depletion of 5-year average base flow (percent) } \\
\hline $\mathrm{EPS}=0.125(\mathrm{~A}-\mathrm{F} / \mathrm{A}) / \mathrm{Yr}$ & 27.3 & 36.4 & 18.2 & -0.2 & 27.2 & 19.2 & 16.3 & 20.2 & 4.9 & 21.6 \\
\hline $\mathrm{EPS}=0.250(\mathrm{~A}-\mathrm{F} / \mathrm{A}) / \mathrm{Yr}$ & 46.4 & 92.9 & 60.0 & 0.5 & 66.4 & 39.9 & 68.7 & 64.5 & 15.6 & 47.0 \\
\hline $\mathrm{EPS}=0.392(\mathrm{~A}-\mathrm{F} / \mathrm{A}) / \mathrm{Yr}$ & 71.4 & 100.0 & 99.4 & 3.2 & 92.8 & 67.1 & 99.6 & 100.0 & 30.9 & 73.4 \\
\hline
\end{tabular}




\section{Effects of No Withdrawals on Base Flow}

During the course of the Arbuckle-Simpson Hydrology Study, the issue of quantification of the effects of current (2011) groundwater withdrawals was raised in stakeholder meetings. The eastern Arbuckle-Simpson aquifer MODFLOW model was used to estimate the current (2011) streamflow depletion caused by the existing groundwater withdrawals for water years 2004-8. The same MODFLOW model used in the simulations of distributed withdrawals was used, but no groundwater withdrawals were simulated. The simulation of no groundwater withdrawals allowed for computation of base flow to streams at a time prior to development of wells in the aquifer. Similar to the simulations of distributed withdrawals, the 5 -water-year period was repeated sequentially by applying the 2004- 8 recharge and by using the distribution of head at the end of one simulation as the starting distribution of head for the next 5-water-year period until average base flow at the Blue River near Connerville, Oklahoma, and the Pennington Creek near Reagan, Oklahoma, streamgages changed by less than 1 percent.
The result of the no-withdrawal simulation was compared to the calibrated transient model, which incorporated the reported water use in the simulation (table 26). Because streamflow and base flow for streams other than Blue River and Pennington Creek were not considered during the transient calibration process, the magnitudes of the flows and the depletion for those streams should not be considered to be calibrated. The simulation with no groundwater withdrawals shows equal or greater base flow to all streams when compared to the transient calibrated model, as might be anticipated. Depletion of average flow was calculated as a negative number to be consistent with simulations in which the calibrated transient simulation, by using reported water use, was considered to be zero depletion. The 5-year average base-flow depletion was as great as -14.4 percent on Sheep Creek, with a 5-year average total depletion of -4.1 percent, meaning that the MODFLOW simulated average base flow was 4.1 percent greater when groundwater withdrawals were removed from the simulation.

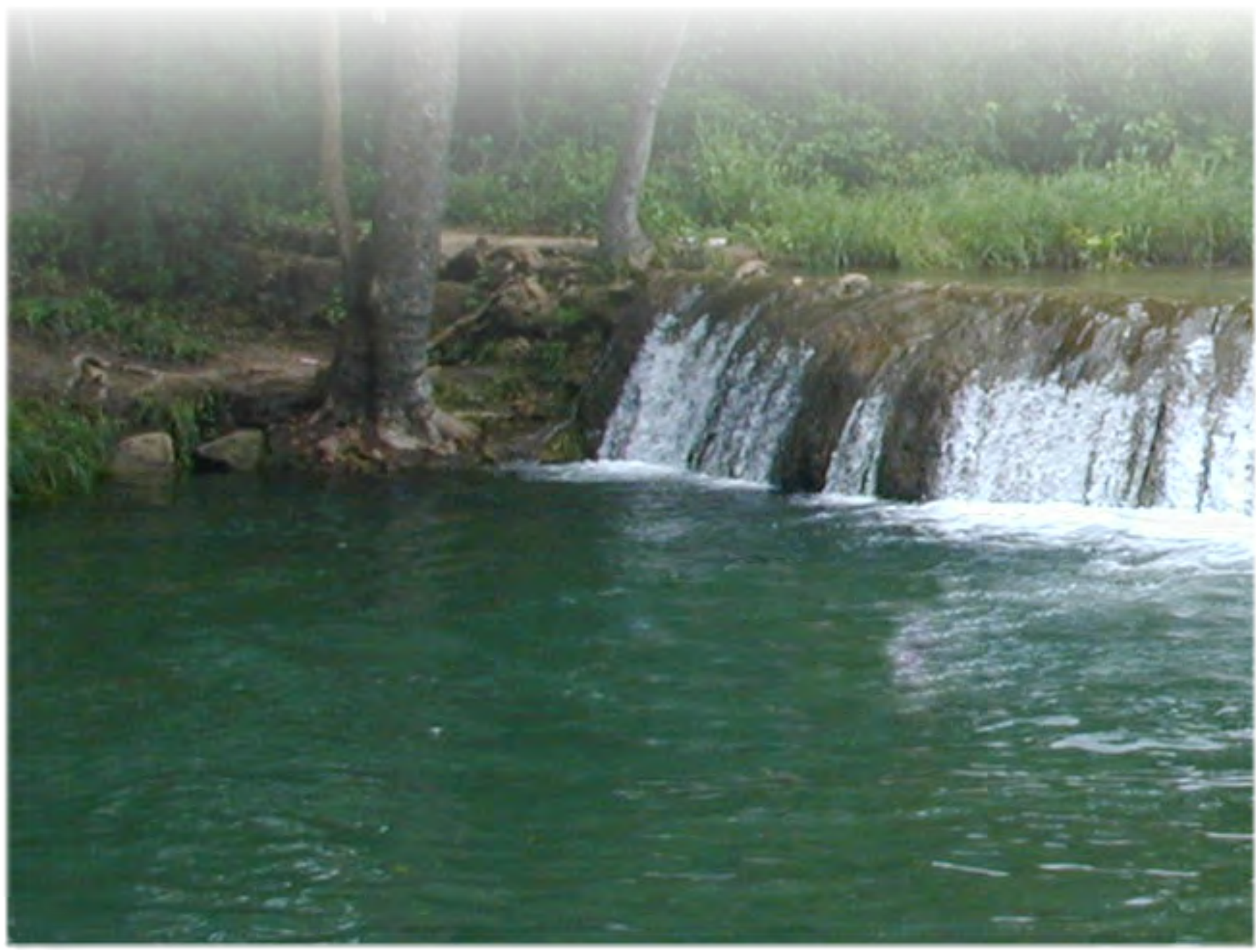


Table 26. Five-year average base flow for water years 2004-8 and depletion of 5-year average base flow for all streams simulated by the eastern Arbuckle-Simpson aquifer MODFLOW based on a simulation of no groundwater withdrawals.

$\left[\mathrm{ft}^{3} / \mathrm{s}\right.$, cubic feet per second $]$

\begin{tabular}{|c|c|c|c|c|c|c|c|c|c|c|}
\hline \multirow[b]{2}{*}{ Simulation } & \multicolumn{10}{|c|}{ Stream } \\
\hline & $\begin{array}{l}\text { Blue } \\
\text { River }\end{array}$ & $\begin{array}{c}\text { Buckhorn } \\
\text { Creek }\end{array}$ & $\begin{array}{c}\text { Byrds Mill } \\
\text { Spring }\end{array}$ & $\begin{array}{c}\text { Delaware } \\
\text { Creek }\end{array}$ & $\begin{array}{c}\text { Mill } \\
\text { Creek }\end{array}$ & $\begin{array}{c}\text { Pennington } \\
\text { Creek }\end{array}$ & $\begin{array}{l}\text { Sheep } \\
\text { Creek }\end{array}$ & $\begin{array}{c}\text { Travertine } \\
\text { Creek }\end{array}$ & $\begin{array}{l}\text { All other } \\
\text { streams } \\
\text { combined }\end{array}$ & Total \\
\hline \multicolumn{11}{|c|}{ 5-year average base flow $\left(\mathrm{ft}^{3} / \mathrm{s}\right)$} \\
\hline Reported water use & 61.34 & 2.65 & 12.95 & 4.92 & 8.53 & 32.19 & 4.44 & 15.41 & 10.18 & 152.60 \\
\hline No withdrawals & 63.68 & 2.96 & 13.55 & 4.94 & 8.96 & 32.50 & 5.08 & 16.90 & 10.25 & 158.80 \\
\hline \multicolumn{11}{|c|}{ Depletion of 5-year average base flow (percent) } \\
\hline No withdrawals & -3.8 & -11.5 & -4.6 & -0.5 & -5.1 & -1.0 & -14.4 & -9.6 & -0.7 & -4.1 \\
\hline
\end{tabular}




\section{Summary}

The Arbuckle-Simpson aquifer in south-central Oklahoma provides water for public supply, farms, mining, wildlife conservation, recreation, and the scenic beauty of springs, streams, and waterfalls. The outcrop of the aquifer has an area of about 520 square miles and is in Carter, Coal, Johnston, Murray, and Pontotoc Counties. Water use from the aquifer is small, with an average annual reported use of only 4,510 acre-feet from 1964 to 2008. However, most of the reported use is from the eastern part of the aquifer with an average of 4,299 acre-feet over the same timeframe, of which 63 percent is for public supplies. The eastern part of the aquifer provides drinking water to about 39,000 people in the cities of Ada and Sulphur, and surrounding areas. Water from most wells completed in the aquifer is suitable for all regulated uses, with a median dissolved solids concentration of 347 milligrams per liter.

Proposed development of water supplies from the aquifer led to concerns that large-scale withdrawals of water would cause decreased flow in rivers and springs, which in turn could result in the loss of water supplies, recreational opportunities, and aquatic habitat. In response to these concerns, the Oklahoma Senate passed Senate Bill 288, which imposed a moratorium on the issuance of any temporary groundwater permit for municipal or public water-supply use outside of any county that overlies a "sensitive sole source groundwater basin." The Arbuckle-Simpson aquifer is considered a "sensitive sole source groundwater basin" because the U.S. Environmental Protection Agency designated the eastern Arbuckle-Simpson aquifer as a "Sole Source Aquifer" in 1989. As of 2011, the Arbuckle-Simpson aquifer was the only designated "Sole Source Aquifer" in Oklahoma. Senate Bill 288 states that the moratorium will remain in effect until the Oklahoma Water Resources Board completes a hydrological study of the sensitive sole source groundwater basin and approves a maximum annual yield that will ensure that any permit for the removal of water from the sensitive sole source groundwater basin will not reduce the natural flow of water from springs or streams emanating from the basin. The Oklahoma Water Resources Board, in collaboration with the Bureau of Reclamation, the U.S. Geological Survey, Oklahoma State University, and the University of Oklahoma, studied the Arbuckle-Simpson aquifer to provide the scientific information needed to determine the volume of water that could be withdrawn while protecting springs and streams. The U.S. Geological Survey, in cooperation with the Oklahoma Water Resources Board, did a study to describe the hydrogeology and simulation of groundwater flow of the aquifer.

The outcrop of the Arbuckle-Simpson aquifer lies in an uplifted area commonly referred to as the Arbuckle Mountains. The Arbuckle Mountains consist of folded and faulted Proterozoic and Cambrian igneous and metamorphic rocks and Paleozoic sedimentary rocks that range in age from Cambrian through Late Pennsylvanian. The geology of the
Arbuckle Mountains is characterized by great thicknesses of mostly carbonate sedimentary rocks, uplifts, folded structures, and large fault displacements.

The Arbuckle-Simpson aquifer is contained in three major rock units of Late Cambrian to Middle Ordovician age: the Timbered Hills, Arbuckle, and Simpson Groups. The aquifer is underlain by low permeability basement rocks, consisting of Cambrian rhyolites and Proterozoic granites and gneisses. In areas where the top of the aquifer dips below the surface, the aquifer is confined above by younger rocks of various ages. The geologic units were grouped into four hydrostratigraphic units for modeling: basement, ArbuckleTimbered Hills, Simpson, and post-Simpson.

The Late Cambrian-age Timbered Hills Group, consisting of the Reagan Sandstone and the Honey Creek Formation, overlies the irregular surface of eroded igneous and metamorphic rocks of the basement unit and is exposed only in small areas in the Arbuckle-Simpson aquifer. Because little is known about the water-bearing properties of the Timbered Hills Group and no identifiable confining layer separates the Timbered Hills Group from the overlying Arbuckle Group in the Arbuckle Mountains, the Timbered Hills Group is considered to be part of the Arbuckle-Simpson aquifer. For this study, the Arbuckle and Timbered Hills Groups are designated as the Arbuckle-Timbered Hills hydrostratigraphic unit.

The Arbuckle Group of Late Cambrian to Early Ordovician age overlies the Timbered Hills Group. The Arbuckle Group consists of a thick sequence of carbonate rocks that is as much as 6,700 feet of limestone in the western Arbuckle-Simpson aquifer, but which thins to an estimated 3,000 feet of predominantly dolostone in the eastern ArbuckleSimpson aquifer. The entire Arbuckle Group has been removed by erosion over parts of the Belton, Tishomingo, and Arbuckle anticlines. The Arbuckle Group constitutes the major part of the Arbuckle-Simpson aquifer in terms of thickness, outcrop extent, and volume of groundwater. Water is obtained from cavities, solution channels, fractures, and intercrystalline porosity in the limestone and dolostone. Wells completed in the Arbuckle Group commonly yield 200 to 500 gallons per minute. Some deeper wells (800-2,000 feet) are reported to yield as much as 2,500 gallons per minute, whereas shallow wells may yield only minor amounts.

The Simpson Group of Middle Ordovician age is as much as 2,300 feet thick in the western Arbuckle-Simpson aquifer, but generally is less than 1,000 feet thick in the eastern Arbuckle-Simpson aquifer. The Simpson Group is characterized by porous quartzose sandstones interbedded with limestones and shales. Water in the Simpson Group is stored primarily in pore spaces between the sand grains in the sandstones. Wells completed in the Simpson can yield from 100 to 200 gallons per minute.

Rock units younger than the Simpson Group overlie the Arbuckle-Simpson aquifer beyond the aquifer outcrop and for this study are designated as "post-Simpson" geologic units. Of primary interest to this study is the Vanoss Group, which 
confines the Arbuckle-Simpson aquifer near Sulphur and Chickasaw National Recreation Area.

The Arbuckle-Simpson aquifer consists of a series of northwest-southeast-trending structural features that are separated from each other by major Paleozoic fault zones. Structural deformation is greatest in the western ArbuckleSimpson aquifer, where vertical and overturned beds are evident. Structural deformation is less pronounced in the central and eastern Arbuckle-Simpson aquifer, where the rocks are more flat lying (dips less than 20 degrees), and are deformed mainly by block faulting.

A digital, three-dimensional geologic framework model was constructed to define the geometric relations of the fault blocks and hydrostratigraphic units of the eastern Arbuckle-Simpson aquifer. The model contains 54 faults and the four hydrostratigraphic units (basement, ArbuckleTimbered Hills, Simpson, and post-Simpson). Construction of the model involved integrating geologic and geophysical data from existing maps and surveys, and data from 126 drill holes. The framework model defined the tops and thicknesses of the post-Simpson, Simpson, and Arbuckle-Timbered Hills hydrostratigraphic units, and the top of the basement hydrostratigraphic unit. Data from the three-dimensional geologic framework model of the eastern Arbuckle-Simpson aquifer provided the geologic data for the eastern ArbuckleSimpson aquifer MODFLOW groundwater-flow model.

Perennial streams that originate in the ArbuckleSimpson aquifer include Blue River, Buckhorn Creek, (Byrds) Mill Creek, Delaware Creek, Honey Creek, Mill Creek, Pennington Creek, Oil Creek, and Travertine Creek. Groundwater discharge from the aquifer maintains base flow to these streams, and many small streams. Blue River, which drains a large part of the eastern Arbuckle-Simpson aquifer, is the largest stream that originates in the study area. Several streamgages in or near the study area were in operation prior to the start of this study and several streamgages were installed for the study.

Many springs discharge from the Arbuckle-Simpson aquifer. The U.S. Geological Survey's National Water Information System database lists 140 springs in the study area. Many of the springs are near the boundary of the aquifer outcrop at the downgradient end of the groundwaterflow system where the more permeable Arbuckle-Simpson aquifer abuts the less permeable basement and post-Simpson hydrostratigraphic units. During most years, discharge from springs maintains flow in the larger streams in the study area in the absence of rainfall. Byrds Mill Spring, with an average annual discharge of 18.5 cubic feet per second, is the largest spring in Oklahoma and serves as the primary water supply for the City of Ada.

The hydrostratigraphic units that form the ArbuckleSimpson aquifer contain fresh and saline water; for this study, the extent of the Arbuckle-Simpson aquifer is considered to be that part of those hydrostratigraphic units that produce freshwater. The current (2011) and previous studies of the aquifer determined that wells and springs in the outcrop produced freshwater. The depth of fresh groundwater in the outcrop area is not known, but the few deep wells drilled in the outcrop do not produce saline water. Freshwater is known to extend beyond the aquifer outcrop near the town of Sulphur and Chickasaw National Recreation Area, where groundwater flows west from the outcrop of the eastern Arbuckle-Simpson aquifer and becomes confined beneath the post-Simpson hydrostratigraphic unit. Groundwater flowing beneath the post-Simpson hydrostratigraphic unit discharges to springs, streams, and wells, some of which are flowing (artesian) wells. Outside the freshwater zone, the water chemistry changes quickly and becomes saline. Beyond the outcrop area of the aquifer, the Arbuckle and Simpson Groups contain brine and are major producers of oil and gas.

The Arbuckle-Simpson aquifer is confined and unconfined in different parts of the study area. The aquifer is confined on the western part of the eastern Arbuckle-Simpson aquifer by the post-Simpson hydrostratigraphic unit. The confining properties of the post-Simpson hydrostratigraphic unit are thought to be the result of cemented conglomerates and shales in the Vanoss Group. Further indication that the western part of the eastern Arbuckle-Simpson aquifer is confined includes the numerous flowing wells near Sulphur, and carbon-14 dating of water samples from a flowing well that determined the age of the water to be 10,500 years. Unconfined conditions are indicated where the Arbuckle-Timbered Hills hydrostratigraphic unit is at land surface and no confining layer is present. Indications that the Arbuckle-Timbered Hills hydrostratigraphic unit is unconfined include (1) water levels rise rapidly in wells in response to precipitation, and (2) groundwater samples from wells in the outcrop of the Arbuckle Group were dated as post-1950, meaning the water resident in that part of the aquifer at the time the samples were collected (2004-6) was recharged recently.

The Simpson Group includes sandstones, shales, and limestones, which transmit substantial quantities of water horizontally and yield sufficient quantities of water to wells to be considered an aquifer. However, several characteristics indicate that the Simpson Group may act as a confining layer. These characteristics are (1) a 1,400-ft-deep flowing well drilled through the Simpson Group into the Arbuckle Group, (2) the hydraulic gradients on the potentiometric maps are larger in the Simpson Group exposures than in the adjacent Arbuckle Group, and (3) a group of springs along Blue River on the outcrop of the Arbuckle Group immediately before Blue River flows across the Simpson Group.

Potentiometric-surface maps were constructed for all or parts of the Arbuckle-Simpson aquifer in the past and as part of this study and include (1) a potentiometric-surface map of the entire Arbuckle-Simpson aquifer made using measurements during the winters of 1976-7 and 1977-8, during a previous study; (2) a potentiometric-surface map of the eastern Arbuckle-Simpson aquifer made from synoptic measurements in August 1995, during a previous study; (3) several potentiometric-surface maps of the eastern 
Arbuckle-Simpson aquifer from synoptic measurements made during the course of this study. Some features are common to all the potentiometric surfaces in the eastern Arbuckle-Simpson aquifer, regardless of the time the measurements were made. The potentiometric surface in the eastern Arbuckle-Simpson aquifer generally slopes from a topographic high, at about $\mathrm{N} 34^{\circ} 35^{\prime}$ latitude, $\mathrm{W} 96^{\circ}$ $50^{\prime}$ longitude, to the southeast, indicating that regional groundwater flow is predominantly toward the southeast (although some groundwater flows to the west and southwest), where groundwater discharges to streams and springs at the boundary of the aquifer. The hydraulic gradient in the Simpson Group is larger than the gradient in the Arbuckle Group.

Subsurface watersheds were delineated on the eastern Arbuckle-Simpson aquifer. The area and boundaries of the subsurface watersheds deviate from the surface watersheds. The largest difference between the surface and subsurface watersheds is at the northern extent of the eastern ArbuckleSimpson aquifer, where the Blue River surface watershed was delineated into the Blue River, Byrds Mill Spring, and Sheep Creek subsurface watersheds.

The primary source of groundwater in the ArbuckleSimpson aquifer is diffuse recharge from precipitation in the outcrop area. The primary method used to determine recharge for the Arbuckle-Simpson aquifer for this study was a recession-curve-displacement method, used to analyze daily stream discharge data for streamgages on the ArbuckleSimpson aquifer. Recharge to the aquifer varies spatially and temporally. Spatial variation is seen by comparing recharge between Blue River, Honey Creek, and Pennington Creek for any given quarter or year; the differences between Blue River and Pennington Creek are particularly striking because those drainage basins are adjacent to each other. Recharge tends to be highest in the January-March and April-June quarters and lowest during the July-September quarter.

The hydraulic properties of the Arbuckle-Simpson aquifer were calculated using several methods, including an aquifer test and several regional methods. Transmissivity from the analytical solution analysis of the aquifer test was 12,000 feet squared per day, and although the test was not of sufficient duration to confidently determine a storage coefficient, the best fit between the analytical solution and the recovery data was achieved with a storage coefficient of 0.011 . Storage coefficient was calculated using several regional methods. Storage coefficients calculated by regional methods ranged from 0.00211 to 0.07475 , with a mean value of 0.00926 and a median value of 0.00646 .

Average annual reported groundwater use from the eastern Arbuckle-Simpson aquifer from 1964 through 2008 was 4,299 acre-feet with a median annual use of 3,532 acrefeet. Minimum and maximum use was 2,287 acre-feet in 1972 and 8,347 acre-feet in 2006, respectively. Most of the water utilized from the aquifer serves public water supply systems with an average annual use from 1964 to 2008 of 2,697 acre-feet, or 63 percent of the total reported groundwater use.
Groundwater withdrawals typically are greatest in August and least in March.

A MODFLOW groundwater-flow model was developed to simulate groundwater flow in the eastern Arbuckle-Simpson aquifer. One of the objectives of the Arbuckle-Simpson Hydrology Study was to consider the potential effects of groundwater withdrawals on spring and stream flows and, therefore, the model calibration was optimized to simulate groundwater flow to Blue River and Pennington Creek, the streams with the largest flows in the study area. Horizontal discretization in the model was 200 meters ( 656 feet) by 200 meters ( 656 feet), and six layers were used to represent the aquifer over a model area of 1,002 square kilometers (387.1 square miles). Model hydraulic variables were assigned based on the hydrostratigraphic unit at each model node; these variables are horizontal hydraulic conductivity, vertical anisotropy, and specific storage (the aquifer was modeled as confined). Recharge was specified in the eastern ArbuckleSimpson aquifer groundwater-flow model using four zones based on the hydrostratigraphic unit at the land surface: post-Simpson, Simpson, Arbuckle-Timbered Hills (north of Sulphur fault), and Arbuckle-Timbered Hills (south of Sulphur fault). Groundwater discharge from the aquifer to streams was simulated with the MODFLOW drain package.

The model was calibrated using the parameter-estimation process in MODFLOW to steady-state conditions using a set of synoptic head and flow observations from August 1995. The calibrated steady-state model reproduced the major features observable in the August 1995 potentiometric-surface map and observed streamflows. The model was calibrated to transient conditions for the 5-water-year time period starting October 1, 2003, through September 30, 2008, corresponding to water years 2004 through 2008. Base flow was simulated by the MODFLOW model and runoff for Blue River and Pennington Creek was calculated from streamgage data using the PART program. Specific storage was set to 0.000008 per meter, and recharge initially was set to the daily recharge computed by the RORA program but adjusted during the calibration process to match streamflows at the Blue River near Connerville, Oklahoma, and the Pennington Creek near Reagan, Oklahoma, streamgages. Area-weighted annual recharge rates applied to the eastern Arbuckle-Simpson MODFLOW model domain averaged 5.58 inches (142 millimeters) per year for water years $2004-8$, and ranged from 2.57 inches (65.3 millimeters) in water year 2006 to 11.61 inches (295 millimeters) in water year 2007. Total gaged flow for the 5-water-year period at the Blue River near Connerville, Oklahoma, streamgage was 336,712 acre-feet and the total simulated flow (MODFLOWsimulated groundwater discharge plus PART-computed runoff) was 336,946 acre-feet. Total gaged flow for the 5-water-year period for the Pennington Creek near Reagan, Oklahoma, streamgage was 155,720 acre-feet, and the total simulated flow was 154,699 acre-feet.

Three simulations of distributed withdrawals were tested, allocating groundwater withdrawals as equal proportionate shares of $0.125,0.250$, and 0.392 (acre-feet/acre)/year. An 
equal proportionate share is the amount of water a permitted user can withdraw from a groundwater basin, based on the amount of land dedicated to a groundwater-use permit. The equal proportionate share of 0.392 (acre-feet/acre)/year is equivalent to 4.7 inches per year, which was the average recharge rate of the Arbuckle-Simpson aquifer reported in a previous study. Simulated depletion of average streamflow for water years $2004-8$ at the Blue River near Connerville, Oklahoma, streamgage was 17.62 percent for a distributed withdrawal of 0.125 (acre-feet/acre)/year, 35.63 percent for a distributed withdrawal of 0.250 (acre-feet/acre)/year, and 53.49 percent for a distributed withdrawal of 0.392 (acre-feet/ acre)/year. Simulated depletion of average streamflow for water years 2004-8 at the Pennington Creek near Reagan, Oklahoma, streamgage was 18.18 percent for a distributed withdrawal of 0.125 (acre-feet/acre)/year, 36.22 percent for a distributed withdrawal of 0.250 (acre-feet/acre)/year, and 56.59 percent for a distributed withdrawal of 0.392 (acre-feet/ acre)/year. The model also showed that increasing withdrawal of groundwater from the aquifer will result in fewer locations where groundwater is discharging to streams and springs.

\section{References Cited}

Agarwal, R.G., 1980, A new method to account for producing time effects when drawdown type curves are used to analyze pressure build up and other test data, presented at the Society of Petroleum Engineers Annual Technical Conference and Exhibition, Sept. 21-24, 1980: Dallas, Society of Petroleum Engineers paper 9289, 20 p.

Ahlfeld, D.P., Barlow, P.M., and Mulligan, A.E., 2005, GWM-A ground-water management process for the U.S. Geological Survey modular ground-water model (MODFLOW-2000): U.S. Geological Survey Open-File Report 2005-1072, 124 p.

Alley, W.M., 2003, Desalination of ground water-Earth science perspective: U.S. Geological Survey Fact Sheet FS-075-03, 4 p.

Anderson, M.P., 1995, Groundwater modeling in the 21st century, in El-Kadi, A.I., ed., Groundwater models for resource analysis and management: Lewis Publishers, p. 81-93.

Angelini, Paola, and Dragoni, Walter, 1997, The problem of modeling limestone springs - The case of Bagnara (North Apennines, Italy): Groundwater, v. 35, no. 4, p. 612-618.

Boyd, D.T., 2002, Oklahoma oil and gas fields: Oklahoma Geological Survey Geologic Map GM36, 128 p.

Campbell, J.A., and Weber, J.L., 2006, Wells drilled to basement in Oklahoma: Oklahoma Geological Survey Special Publication 2006-1, CD-ROM.
Cates, S.W., 1989, Fault distribution in the Sulphur, Oklahoma area based on gravity, magnetic and structural data: Norman, University of Oklahoma, M.S. thesis, 106 p.

Cederstrand, J.R., 1996, Digital geologic map of ArdmoreSherman quadrangles, south-central Oklahoma: U.S. Geological Survey Open-File Report 96-370. (Available online at http://ok.water.usgs.gov/gis/geology.)

Center for Spatial Analysis, 2004, (2000) Population by census blocks: University of Oklahoma, accessed May, 10, 2005, at http://csa.ou.edu/.

Christenson, Scott, Hunt, A.G., and Parkhurst, D.L., 2009, Geochemical investigation of the Arbuckle-Simpson aquifer, south-central Oklahoma, 2004-06: U.S. Geological Survey Scientific Investigations Report 2009-5036, 51 p.

Committee on Fracture Characterization and Fluid Flow, 1996, U.S. national committee for rock mechanics, rock fractures and fluid flow: Washington, D.C., National Academy Press, $551 \mathrm{p}$.

Czarnecki, J.B., Gillip, J.A., Jones, P.M., and Yeatts, D.S., 2009, Groundwater-flow model of the Ozark Plateaus aquifer system, northwestern Arkansas, southeastern Kansas, southwestern Missouri, and northeastern Oklahoma: U.S. Geological Survey Scientific Investigations Report 2009-5148, 62 p.

D’Agnese, F.A., Faunt, C.C., Hill, M.C., and Turner, A.K., 1999, Death Valley regional ground-water flow model calibration using optimal parameter estimation methods and geoscientific information systems, in Leijnse, A., and Hill, M.C., eds., Special Section on Model Calibration and Reliability Evaluation for Groundwater Systems: Advances in Water Resources, v. 22, no. 8, p. 777-790.

Dahlberg, E.C., 1994, Applied hydrodynamics in petroleum exploration: New York, Springer-Verlag, 295 p.

Davis, R.E., and Christenson, S.C., 1979, Methods for digitalmodel evaluation of alluvial deposits of the North Canadian River, northwest Oklahoma [abs.]: Geological Society of America, South-Central Section, April 9-10, 1979, Abstracts with Programs, v. 11, no. 2, p. 146.

Denison, R.E., 1973, Basement rocks in the Arbuckle Mountains, in Ham, W.E., ed., Regional geology of the Arbuckle Mountains, Oklahoma: Oklahoma Geological Survey Special Publication 73-3, p. 43-46.

Denison, R.E., 1989, Middle Cambrian through Early Ordovician, in Johnson, K.S. and others, eds., Geology of the southern Midcontinent: Oklahoma Geological Survey Special Publication 89-2, p. 4-7. 
Denison, R.E., 1995, Significance of air-photograph linears in the basement rocks of the Arbuckle Mountains, in Johnson, K.S., ed., Structural styles in the southern Midcontinent, 1992 Symposium: Oklahoma Geological Survey Circular 97, p. 119-131.

Denison, R.E., 1997, Contrasting sedimentation inside and outside the southern Oklahoma aulacogen during the Middle and Late Ordovician, in Johnson, K.S., ed., Simpson and Viola Groups in the southern Midcontinent, 1994 Symposium: Oklahoma Geological Survey Circular 99, p. 39-47.

Donovan, R.N., 1991, The Arbuckle Group_-An aide de memoire, in Johnson, K.S., ed., Arbuckle Group Core Workshop and Field Trip: Oklahoma Geological Survey Special Publication 91-3, p. 199-208.

Donovan, R.N., and Butaud, Todd, 1993, The Vanoss conglomerate-A record of Late Pennsylvanian basin inversion on the northern flank of the Arbuckle Mountains, southern Oklahoma, in Johnson, K.S., and Campbell, J.A., eds., Petroleum-reservoir geology in the southern Midcontinent, 1991 symposium: Oklahoma Geological Survey Circular 95, p. 10-24.

Donovan, R.N., and Ross, D.L., 1991, The Saddle Mountain Dolomite at Maukeen Hill-A dolomite interface in the upper Arbuckle Group, western Slick Hills, Oklahoma, in Johnson, K.S., ed., Late Cambrian-Ordovician geology of the southern Midcontinent, 1989 symposium: Oklahoma Geological Survey Circular 92, p. 143-153.

Environmental Systems Research Institute, 2001, ArcGIS spatial analyst - Advanced GIS spatial analysis using raster and vector data, accessed October 25, 2010, at http:// www.esri.com/library/whitepapers/pdfs/arcgis_spatial_ analyst.pdf.

Fairchild, R.W., Hanson, R.L., and Davis, R.E., 1990, Hydrology of the Arbuckle Mountains area, south-central Oklahoma: Oklahoma Geological Survey Circular 91, 112 p., 2 pls., scale 1:100,000.

Faith, J.R., Blome, C.D., Pantea, M.P., Puckette, J.O., Halihan, Todd, Osborn, Noel, Christenson, Scott, and Pack, Skip, 2010, Three-dimensional geologic model of the ArbuckleSimpson aquifer, south-central Oklahoma: U.S. Geological Survey Open-File Report 2010-1123, 26 p.

Ferris, J.G., Knowles, D.B., Brown, R.H., and Stallman, R.W., 1962. Theory of aquifer tests: U.S. Geological Survey Water-Supply Paper 1536-E, 174 p.

Halihan, Todd, Mouri, Sassan, and Puckette, Jim, 2009a, Evaluation of fracture properties of the Arbuckle-Simpson aquifer-Final report submitted to the Oklahoma Water Resources Board, Oklahoma State University School of Geology, 64 p.
Halihan, Todd, Puckette, Jim, Sample, Michael, and Riley, Matthew, 2009b, Electrical resistivity imaging of the Arbuckle-Simpson aquifer-Final report submitted to the Oklahoma Water Resources Board, Oklahoma State University School of Geology, 152 p.

Ham, W.E., 1945, Geology and glass sand resources, central Arbuckle Mountains, Oklahoma: Oklahoma Geological Survey Bulletin 65, 103 p.

Ham, W.E., 1949, Geology and dolomite resources, Mill Creek-Ravia area, Johnston County, Oklahoma: Oklahoma Geological Survey Circular 26, 104 p.

Ham, W.E., 1950, Geology and petrology of the Arbuckle Limestone in the southern Arbuckle Mountains, Oklahoma: New Haven, Conn., Yale University, Ph.D. dissertation, $162 \mathrm{p}$.

Ham, W.E., 1973, Regional geology of the Arbuckle Mountains, Oklahoma: Oklahoma Geological Survey Special Publication 73-3, 61 p.

Ham, W.E., Denison, R.E., and Merritt, C.A., 1964, Basement rocks and structural evolution of southern Oklahoma: Oklahoma Geological Survey Bulletin 95, 5 pls., 302 p.

Ham, W.E., McKinley, M.E., Johnson, K.S., Dunham, R.J., Decker, C.E., Morgan, G.D., Barker, J.C., and Gillert, M.P., 1990, Geologic map and sections of the Arbuckle Mountains, Oklahoma: Oklahoma Geological Survey, Geologic Map GM-31, scale 1:100,000.

Hanson, R.L., and Cates, S.W., 1994, Hydrology of the Chickasaw National Recreation Area, Murray County, Oklahoma: U.S. Geological Survey Water-Resources Investigations Report 94-4102, 86 p., 2 pls., scale 1:24,000.

Harbaugh, A.W., 1990, A computer program for calculating subregional water budgets using results from the U.S. Geological Survey modular three-dimensional groundwaterflow model: U.S. Geological Survey Open-File Report 90-392, 46 p.

Harbaugh, A.W., Banta, E.R., Hill, M.C., and McDonald, M.G., 2000, MODFLOW-2000, the U.S. Geological Survey modular groundwater model-User guide to modularization concepts and the groundwater flow process: U.S. Geological Survey Open-File Report 00-92, 121 p.

Harlton, B.H., 1966, Relation of buried Tishomingo Uplift to Ardmore basin and Ouachita Mountains, southeastern Oklahoma: American Association of Petroleum Geologists Bulletin, v. 50, no. 7, p. 1365-1374.

Hart, D.L., Jr., 1974, Reconnaissance of the water resources of the Ardmore and Sherman Quadrangles, southern Oklahoma: Oklahoma Geological Survey Hydrologic Atlas HA-3, 4 sheets, scale 1:250,000. 
Hill, M.C., 1998, Methods and guidelines for effective model calibration: U.S Geological Survey Water-Resources Investigations Report 98-4005, $90 \mathrm{p}$.

Hill, M.C., and Tiedeman, C.R., 2007, Effective groundwater model calibration - With analysis of data, sensitivities, predictions, and uncertainty: Hoboken, N.J., Wiley and Sons, $480 \mathrm{p}$.

Hydrosolve, Inc., 2010, Aqtesolv for Windows: Hydrosolve, Inc., accessed October 26, 2010, at http://www.aqtesolv.com.

Johnson, K.S., 1991, Geologic overview and economic importance of Late Cambrian and Ordovician rocks in Oklahoma, in Johnson, K.S., ed., Late Cambrian-Ordovician geology of the southern Midcontinent, 1989 symposium: Oklahoma Geological Survey Circular 92, p. 3-14.

Johnson, K.S., Amsden, T.W., Denison, R.E., Dutton, S.P., Goldstein, A.G., Rascoe, B., Sutherland, P.K., and Thompson, D.M., 1989, Geology of the southern Midcontinent: Oklahoma Geological Survey Special Publication 89-2, $53 \mathrm{p}$.

Kennedy, Breanne, 2008, Seismic features of the ArbuckleSimpson aquifer determined from surveys at three different geologic scales: Norman, University of Oklahoma, M.S. thesis, $81 \mathrm{p}$.

Klimchouk, A.B., 2007, Hypogene speleogenesisHydrogeological and morphogenetic perspective: Carlsbad, New Mex., National Cave and Karst Research Institute, Special Paper 1, $106 \mathrm{p}$.

Koltun, G.F., Kula, S.P., and Puskas, B.M., 2006, A streamflow statistics (StreamStats) web application for Ohio: U.S. Geological Survey Scientific Investigations Report 2006-5312, 62 p.

Kuniansky, E.L., Fahlquist, Lynne, and Ardis, A.F., 2001, Travel times along selected flow paths of the Edwards aquifer, Central Texas, in Kuniansky, E.L., ed., U.S. Geological Survey Karst Interest Group Proceedings, February 13-16, 2001, St. Petersburg, Florida: U.S. Geological Survey Water-Resources Investigations Report 01-4011, p. 69-77.

Larocque, M., Banton, O., Ackerer, P., and Razack, Moumtaz, 1999, Determining karst transmissivities with inverse modeling and an equivalent porous media: Ground Water, v. 37, no. 6, p. 897-903.

Leake, S.A., 1997, Modeling ground-water flow with MODFLOW and related programs: U.S. Geological Survey Fact Sheet FS-121-97, 4 p.
Lindsay, R.F., and Koskelin, K.M., 1991, Arbuckle Group depositional parasequences, southern Oklahoma, in Johnson, K.S., ed., Late Cambrian-Ordovician geology of the southern Midcontinent, 1989 symposium: Oklahoma Geological Survey Circular 92, p. 71-84.

Lohman, S.W., 1972, Ground-water hydraulics: U.S. Geological Survey Professional Paper 708, 70 p.

Lohman, S.W., and others, 1972, Definitions of selected ground-water terms-Revisions and conceptual refinements: U.S. Geological Survey Water-Supply Paper 1988, $21 \mathrm{p}$.

Lynch, Mark, and Al-Shaieb, Zuhair, 1991, Evidence of paleokarstic phenomena and burial diagenesis in the Ordovician Arbuckle Group of Oklahoma, in Johnson, K.S., ed., Late Cambrian-Ordovician geology of the southern Midcontinent 1989 symposium: Oklahoma Geological Survey Circular 92, p. 42-60.

Maxey, G.B., 1964, Hydrostratigraphic units: Journal of Hydrology, v. 2, p. 124-129.

McPherson, J.G., Denison, R.E., Kirkland, D.W., and Summers, D.M., 1988, Basal sandstone of the Oil Creek Formation in the quarry of the Pennsylvania Glass Sand Corporation, Johnston County Oklahoma, in Hayward, O.T., ed., Centennial field guide: Geological Society of America, South-Central Section, v. 4., p. 165-170.

National Archives and Records Administration, 1989, Arbuckle-Simpson aquifer of south central Oklahoma Sole Source Aquifer? Final Determination: Federal Register, v. 54, no. 184 , p. 39,230 .

National Climatic Data Center, 2008, Climatography of the United States, no. 20, 1971-2000: Ada, Oklahoma, Precipitation totals, accessed September 29, 2008, at http:// cdo.ncdc.noaa.gov/climatenormals/clim20/ok/340017.pdf.

National Oceanic and Atmospheric Administration, 2009, National Weather Service Cooperative Observer Station ID 340017, 1907-2008 precipitation data, accessed June 29, 2009, at http://www7.ncdc.noaa.gov/IPS/coop/coop.html.

National Oceanic and Atmospheric Administration, 2011, National Weather Service, JetStream - Online School for Weather, appendix, accessed January 3, 2011, at http://www. srh.noaa.gov/jetstream//append/append_intro.htm.

Neuman, S.P., 1974, Effect of partial penetration on flow in unconfined aquifers considering delayed gravity response: Water Resources Research, v. 10, no. 2, p. 303-312.

Oklahoma Climatological Survey, 2007, June 2007 now wettest on record statewide: Oklahoma Climatological Survey News Release, June 29, 2007, accessed January 1, 2010, at http://climate.ok.gov/newsmedia/releases/june record_precip.pdf. 
Oklahoma Climatological Survey, 2010, The climate of Pontotoc County, accessed August 13, 2010, at http:// climate.mesonet.org/county_climate/Products/County_ Climatologies/county_climate_pontotoc.pdf.

Oklahoma Mesonet, 2009, Daily data retrieval, accessed January 20, 2009, at http://www.mesonet.org/index.php/ weather/daily_data_retrieval.

Oklahoma Water Resources Board, 2003, The ArbuckleSimpson hydrology study, management and protection of an Oklahoma water resource: Oklahoma Water Resources Board Fact Sheet, 4 p.

Oklahoma Water Resources Board, 2007, The ArbuckleSimpson hydrology study: Oklahoma City, Oklahoma Water Resources Board, March 2007 newsletter, accessed July 22, 2010, at http://www.owrb.ok.gov/studies/groundwater/ arbuckle_simpson/pdf/arbuckle_newsletter_0307.pdf.

Oklahoma Water Resources Board, 2009, Taking and use of groundwater, Title 785, Chapter 30, Section 1020.1, accessed March 1, 2010, at http:/www.owrb.ok.gov/util/ rules/pdf_rul/Chap30.pdf.

Oklahoma Water Resources Board, 2010, Major groundwater aquifers of Oklahoma, accessed February 15, 2010, at http:// www.owrb.ok.gov/maps/pdf_map/major_aquifers.pdf.

Perry, W.J., Jr., 1989, Tectonic evolution of the Anadarko basin region, Oklahoma: U.S. Geological Survey Bulletin 1866-A, 19 p.

Pollock, D.W., 1994, User's guide for MODPATH/ MODPATH-PLOT, version 3-A particle tracking postprocessing package for MODFLOW, the U.S. Geological Survey finite-difference ground-water-flow model: U.S. Geological Survey Open-File Report 94-464, 248 p.

Puckette, Jim, Halihan, Todd, and Faith, Jason, 2009, Characterization of the Arbuckle-Simpson aquifer-Final report submitted to the Oklahoma Water Resources Board, Stillwater, Oklahoma State University School of Geology, $53 \mathrm{p}$.

Ragland, D.A., and Donovan, R.N., 1991, Sedimentology and diagenesis of the Arbuckle Group in outcrops of southern Oklahoma, in Johnson, K.S., ed., Arbuckle Group Core Workshop and Field Trip: Oklahoma Geological Survey Special Publication 91-3, p. 9-29.

Rahi, Khayyun, and Halihan, Todd, 2009, Estimating selected hydraulic parameters of the Arbuckle-Simpson aquifer from the analysis of naturally-induced stresses_-Final report submitted to the Oklahoma Water Resources Board, Stillwater, Oklahoma State University School of Geology, 48 p.
Remson, Irwin, Hornberger, G.M., and Molz, F.J., 1971, Numerical methods in subsurface hydrology: New York, John Wiley and Sons, Inc., 389 p.

Riley, M.E., 2004, Investigation of fault properties using electrical resistivity imaging: Stillwater, Oklahoma State University, M.S. thesis, 104 p.

Rorabaugh, M.I., 1964, Estimating changes in bank storage and groundwater contribution to streamflow: International Association of Scientific Hydrology, no. 63, p. 432-441.

Rutledge, A.T., 1998, Computer programs for describing the recession of ground-water discharge and for estimating mean ground-water recharge and discharge from streamflow records_Update: U.S. Geological Survey Water-Resources Investigations Report 98-4148, 43 p.

Sample, M.S., 2008, Characterization of the epikarst over the Hunton anticline, Arbuckle-Simpson aquifer, Oklahoma: Stillwater, Oklahoma State University, M.S. thesis, 220 p.

Savoca, M.E., and Bergman, D.L., 1994, Effects of municipal ground-water withdrawals on the Arbuckle-Simpson Aquifer, Pontotoc County, Oklahoma: U.S. Geological Survey Water-Resources Investigations Report 93-4230, $37 \mathrm{p}$.

Scanlon, Bridget, Mace, R.E., Smith, Brian, Hovorka, Susan, Dutton, Alan, and Reedy, Robert, 2001, Groundwater availability of the Barton Springs segment of the Edwards aquifer, Texas-Numerical simulations through 2050: Austin, University of Texas, Bureau of Economic Geology, final report prepared for the Lower Colorado River Authority, under contract no. UTA99-0, 36 p.

Scheirer, D.S., and Aboud, Essam, 2008, Preliminary gravity and ground magnetic data in the Arbuckle Uplift near Sulphur, Oklahoma: U.S. Geological Survey Open-File Report 2008-1003, 34 p.

Scheirer, D.S., and Hosford Scheirer, Allegra, 2006, Gravity investigations of the Chickasaw National Recreation Area, south-central Oklahoma: U.S. Geological Survey Open-File Report 2006-1083, 40 p.

Seilheimer, T.S., and Fisher, W.L., 2008, Instream flow assessment of streams draining the Arbuckle-Simpson aquifer: Final report submitted to the Oklahoma Water Resources Board, 49 p.

Shoemaker, W.B., Kuniansky, E.L., Birk, Steffen, Bauer, Sabastian, and Swain, E.D., 2007, Documentation of a Conduit Flow Process (CFP) for MODFLOW-2005: U.S. Geological Survey Techniques and Methods, book 6, chap. A24, 50 p. 
Smith, D.V., Deszcz-Pan, Maryla, and Smith, B.D., 2009, Depth section imaging for portions of an airborne geophysical survey of the Hunton anticline, south-central Oklahoma: Final administrative report to the Oklahoma Water Resources Board, 38 p.

Sutherland, P.K., 1989, Ardmore and Marietta Basins, in Johnson, K.S., and others, eds., Geology of the southern Midcontinent: Oklahoma Geological Survey Special Publication 89-2, p. 20-25.

Thornthwaite, C.W., 1948, An approach toward a rational classification of climate: Geographical Review, v. 38, no. 1, p. 55-94.

U.S. Geological Survey, 1999, Map accuracy standards: U.S. Geological Survey Fact Sheet FS-171-99, 2 p.

Vieux, B.E., and Moreno, M.A., 2008, Arbuckle-Simpson Hydrology Study—Distributed water resources assessment-Final report submitted to the Oklahoma Water Resources Board, Norman, University of Oklahoma School of Civil Engineering and Environmental Science, $44 \mathrm{p}$.

Walker, L.M., and Bradford, R.E., 2009, The basics of Oklahoma water law-What every practitioner should know: The Oklahoma Bar Journal, v. 80, no. 23, p. 1748-1751.
Weyl, P.K., 1960, Porosity through dolomitizationConservation of mass requirements: Journal of Sedimentary Research, v. 30, no. 1, p. 85-90.

Wilson, J.L., 1993, The Lower Ordovician Great American Bank of the southwestern United States, in Keller, D.R., and Reed, C.L., eds., Paleokarst, karst-related diagenesis, reservoir development and exploration concepts-Examples from the Paleozoic section of the southern Midcontinent 1993 Annual Fieldtrip Guidebook Permian basin section, Society of Economic Paleontologists Mineralogists, Arbuckle Mountains, Oklahoma: Society of Economic Paleontologists and Mineralogists Publication no. 93-34, p 35-43.

Winchester, C.F., and Morris, J.J., 1956, Water intake rates of cattle: Journal of Animal Science, v. 15, p. 722-740.

Woodruff, C.M., Jr., 1977, Stream piracy near the Balcones fault zone, central Texas: Journal of Geology, v. 85, no. 4, p. 483-490.

Worthington, S.R.H., and Ford, D.C., 1995, High sulfate concentrations in limestone springs-An important factor in conduit initiation?: Environmental Geology, v. 25, no. 1, p. $9-15$.

Young, R.A., Kennedy, Breanne, and Russian, Carlos, 2009, Analysis of seismic reflection data from the Hunton anticline: Final report to the Oklahoma Water Resources Board, $13 \mathrm{p}$. 
